Intemperlsmo de gran 1 tos e dlabásios no municiplo de

Campinas e arredores, Estado de São paulo.

ADOLPHO JOSE MELFI

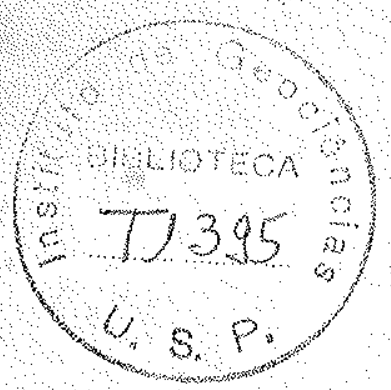

DEDALUS - Acervo - IGC

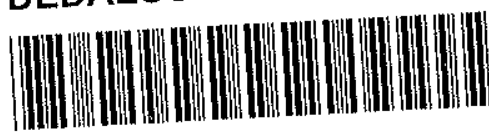

30900005288

T. 


\section{INTEMPERISMO DE GRANITOS E DIABÁSIOS NO MUNICÍPIO DE CAMPINAS E ARREDORES, ESTADO DE SÃO PAULO}

Tese de doutoramento apresentada à Faculdade de Filosofia, Ciências e Letras da Universidade de São Paulo

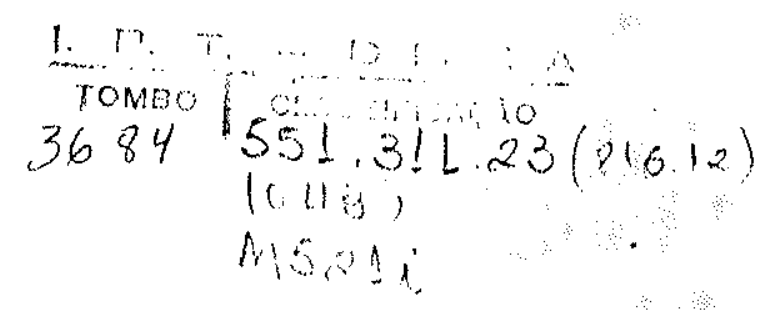

São Paulo - 1967 
INDICE

INTRODUGAO $\ldots \ldots \ldots \ldots \ldots \ldots$

PRIMEIRA FARTE

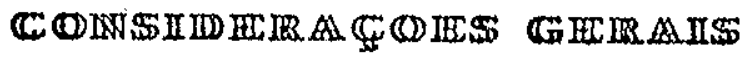

CAPITULO I - ESTUDO DO NIEIO EISICO ....... 6

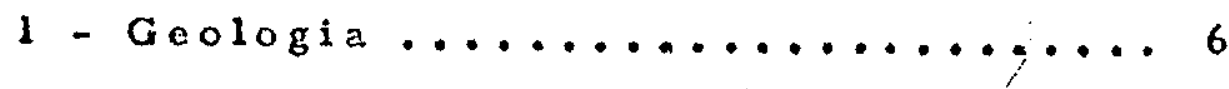

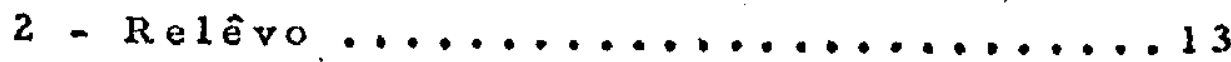

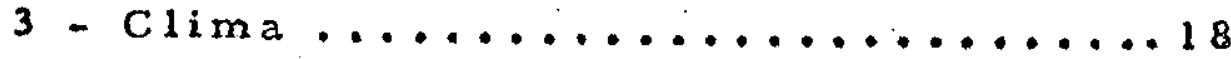

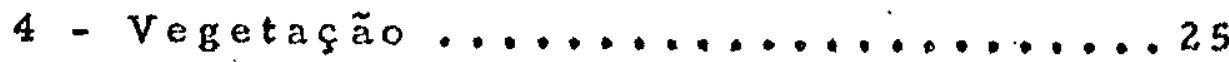

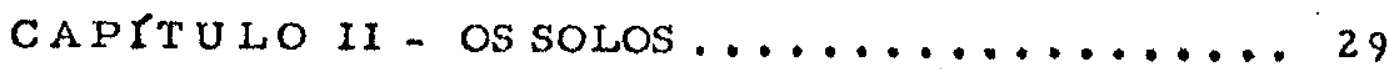

1 - Solos desenvolvidos sôbre granitos 32

2 - Solos desenvolividos sôbre diabásios 37

CAPYTULO III - MATERIAIS E METODOS .......42

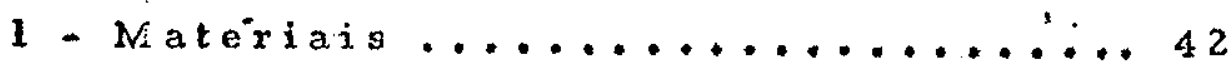

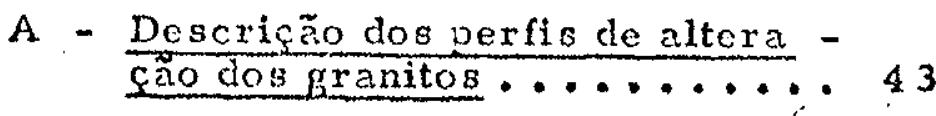

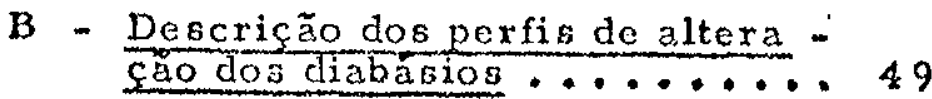

2 - Métodos de investigą̧ões .......56

A - Análise granulométrica ..... 57

$B$ - Análise mineralógica......59

a) Microscopia óptica ...... 59

b) Difraçäo de Raios X ....... 60

c) Análise térmica diferencial. 61.

d) Nicroscopia eletrônica...6 62 
C - Análises químícas ....... 63

a) análisses químicas totais ...663

b) cálculos isovolumétricos .. 63

SEGUNDA PARTE

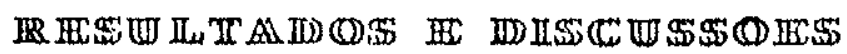

CAPITULO I - ESTUDO DO INTEMPERISMO NOS GRANITOS E A EORNIACAAO DOS PERFIS DE ALTERAÇAO . . . . .

1 - Perfil IT-1

A - Análise granulométrica .... 65

B - Análise mineralógica do perfil 67

C - Análises químicas........ 75

2-Perfil IT-2

s.

A - Análise granulométrica .... 75

B - Análise mineralógica do perfil 79

C - Análises guímicas........ 8 7

3 - Pexfil $M O-1$

- A - Análise granulométrica ..... 87

B - Análise mineralógica do perfil 91

C - Análises químicas ........999 98

CAPITULO II - DISCUSSAO DOS RESULTADOS DO INTENIPERISMO NOS GRANITOS E A FORMAÇAO DOS PERFIS DE ALTERAÇAO.............. 101
A - Análise granulométrica ..... 101
B - Análise mineralógica dosperfis 101
C $-\frac{\text { Comportamento geoquímico dos }}{\text { elementos } \ldots \ldots \ldots \ldots \ldots} 108$ 
CAPITULO III - ESTUDO DO INTEMPERISNO SOBRE OS DIABRISTOS E A FOKMA GT:O DOS PERTIS DE A.LTERA -

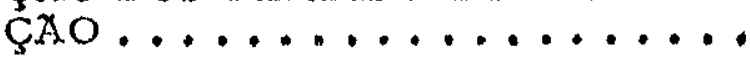

1 - Perfil CA-1
A - Análise granulonnétrica....
B - Análise mineralógica do perfil
115
C - Arálises guímicas ........
124

2. Perfil PA- 1
A. - Análise granulométrica..... 124
$B$ - Análise mineralógica do perfil 128
G - Análises químicas ....... 129

3 . Pexfil AN -1

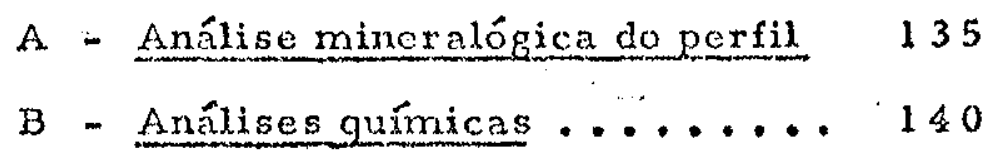

CAPITULO IV - DISCUSSAO DOS RESULTADOS DO INTEN TERISNO SOBRE DIABASIO E A FORMACYAO DOS PEREXS DE

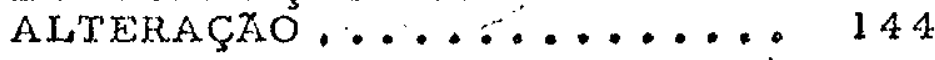
A. Análise granulométrica.....
144
B - Anślise mineralógica dosperfis 144
C - Comportamento geoquímico dos 150

TERCEIRA PARTE

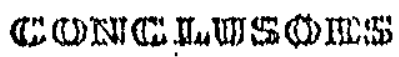

1 - Estabilidade dos mineraisprimários.. 154

2 - Gênese dos minerais de neoformạ̧ão.. 155

3 - Comportamento geoquímico dos elemen-

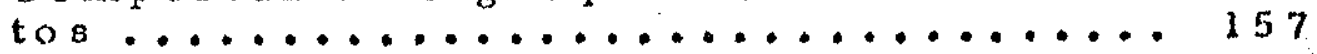

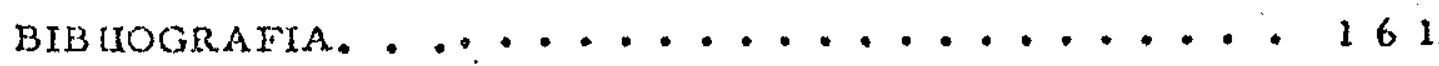


INTRODUÇAO

Com frequência, os geólogos têm suas vistas voltadas pa$\dot{r a}$ o estudo do intemperismo e da formação dos solos, principal mente nas regiöes de climas tropicais e sub-tropicais, em virtude do fato de uma espêssa cobertura de material intemperizado ca pear, pràticamente, tódas as forraçỗes geoiógicas e tor max difícil e, por vêzes, imposøível, a obsexvação direta do substratum geológico.

De longa data os pesquisadores que se dedicarana ao estudo da geologia do Brasil sentiram a necessidade de conhecimentos pedológicos para servir de subsídios a levantamentos geológj.cos. Capanema (1866), Washburne (1930) e Noraes Rego (1935) situam se entre os primeiros que se preocuparam efetivamente com o es tudo dos materiais provenientes do intemperismo das rochas.

Entretantó, entre nós, muito pouca coisa tem sido feita neste campo, que tem também grande importância conômica:bas ta atentarmos para o grande número de jazidas minerais que estão genèticamente associadss a fenômenos intempéricos. O ẹstudo do material intempexizado e seu processo de formação têm, ainda. importância nos problemas ligados à geologia aplicada, haja visto que a estabilidade estrutural de barragens e pontes depende essencialmente da extensão e da intensidade dos efeito o do intemperisma sôbre substratum rochoso.

O intemperismo, como foi definido por Merxil (1897), é o resultado da ação dos divexsos elementos da armosfera e, em pax- 
ticular, da água, do oxigênio, dó gás carbônico e da temperatura sôbre as roqhas, aos quais é necessário ajuntar. em certos casos produtos da vida aninal e vegetal. Ainda segundo Nerril, o intemperismo é um processo tippicamente destrutivo, que permi te o desenvolvimento de novcs minerais a pastir diqueses alterados.

Pesquisadores que no início do século XX estudaram os problemás ligados ao intemperismo faziam nítida separação entre os processos ligados direta ou indiretamente à vida, referi dos comp processos de formação do solo, e aquêles inorgânicos, sem nenhuma relação com qualquer forma de vida, que eram res tritamente denominados intempéricos. Atualmente, todos os au tores modernos consideram os dois processos estreitamente cor relacionados. Ambos ocorrem em virtude da inteirą̧̃o dos mes mos fenômenos, podendo o solo sex considerado simplesmente co mo o produto final da decomposiçăo das rochas.

O intemperismo das rochas e consequente formaça do solo depende de váxios fatôres, designados por Dokuchaiv (citado por De'sigmond, 1938) de pedogenéticos ou formadores do solo. $O$ solo é, portanto, considerado uma função de tais fatôres, tendo Dokuchaiv simbolizado o fenômeno na seguinte equação:

$$
S=f(c, x, m, o, t, \ldots .)
$$

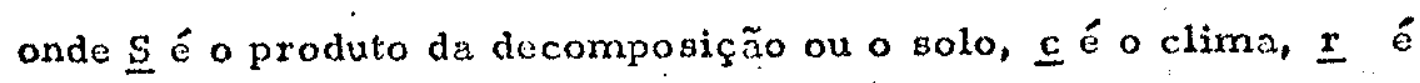
o relêvo, in é o maticial original, o são os organiamos (vege taik e animaia) et ć o tempo. 
Sendo os fatôres acima mencionados os responsáveis di retos pelo intempexismo das rochas e pela formaç⿰彳 dos solos, torna-se indispensável, no trabalho que ora realizamos, fazer uma síntese dos aspectos mais importantes dos referidos fatôr para melhox compreensão da matéria analisada.

O presente trabalho realizado nos anos de 1965 a 1967 tem a finalidade de contribuix para o conhecimento da gânese de determinados tipos de solos tropicais e para elucidar certos aspectos relacionados com o intemperismo, principalmente químico, de rochas magmáticas.

A análise da decomposição meteóxica limitou-se ao estudo de granitos e diabósios que, alérr de sexem rochas bastante comuns na litosfera, possuen comportamento geoquínico análo.go e de interpretaço relativamente simples.

A região de Campinas foi e colhida para a realização de tal estudo, pois os fatồ es de intemperismo e formadores do solo poder ão ấ ser bem documentados, principalmente os climáticos, os geológicos e os geomorfológicos, além do fato de ser pos aível nesta regiäo a obtenção de bons perfís de alteração.

Trabalhos Prévios

A bibliografia nacional, que aborda problemas relacionados corn o estudo do intemperismo das rochas e da gênese dos go Ios formados, é extremamente escassa, mexecendo citaçà os trabalhos de Gutmana (1943). Guerra (1950 e 1952) e Setzer(1960), os quais abordam parcialmente o problema do estudo do material 
proveniente do intemperismo a sua relação com o solo formado. Paiva Netto e Nascimento (1957), analisando os produtos da alteração dos diabásios no Estaclo de São Paulo, tentaxam pe la primeira vez analisar de maneira mais completa a decomposição química das rochas e o produto desta alterą̧̃o. Mais re centemente, Moniz (1964), Ranzani (1965) e Melfi et al.(1967), rea lizaram estudos que podem ser considerados pioneiros para a elucidação de pxoblemas ligados ao intemperismo e gêne ze de nos sos solos.

Entretanto, tal fat não ocorre com relação a trabalhos ę trangeiros realizados neste campo, pois seu núrnero é bastante grande, sendo pràticamente imposuível uma revisão bibliogxáfi ca completa.

Citaremos neste capítulo sòmente os trabalhos realizados principalmente na Africa, onde as condiçõea oferecidar polo raxio físico, bastante similares às nossas, berviram de base para pog síveis comparaçõe日.

Segalen (1957), estudando a gênese dos solo o dexivados das rochas vulcânicas básicas em Niadagascar e correlacionando - a com o tipo de drenagom e com a condições climáticas exis tente na ilha (precipitação e temperatura), mostrou que êstes dois fatôres são de grando importância tanto na qualidade do material intempérico formado, quanto na qualidade do solo originado. Leneuf (1959), em sua tese de doutoxamento, apresenta dados interessantes sôbxe a altexação de granitos e granodioritos em clima tropical, e a gênese dos solos foxmados a partir destas ro 
chas, Bonifas (1959), aborda do maneira bastante detahiada o estu do geoquímico da altexaço laterítica, destacando o comportanen to doo elementos químicon porante o intemperiomo e a formação dos óxidos, hidxóxidos e silicatos hidratados que constituem as formações lateríticas. Frécot et al (1962) realizaram um traba tho sucinto sôbre a altera ão de diversas rochas ígneas, meta mórficas e sedimentares e a formação do solo na região do Kivu; apresentaram resultados referentes à alterą̧̃o dos minerais pri mários, à formação dos minexai s secundáxios e concluiram que os fatôres principais que determinam a natureza dos materiaí de alteração são essencialmente as condições de drenagem e o con teúdo iônico das águas de pexcolação, sendo o papel da rochạmãan apenas o de delimitax as possibilidades de transformą̧ão. Final mente Delvigne (1765) analisa, em seu trabalho, de maseira corn pleta os aspectos ligados à pedogênese na região tropical de Côte-d'Iroire. O autor aborda o comportamento geoquímico dose lementos maiores, sua mobilidade o acumulação dentro do perfil de alteração e formação dos minerai s becundários.

As demais obras consultadas serão citadas no texto, no decorxer do desenvolvimento do trabalho. 


\section{AGRADECIM ENTOG}

Antes de expor os resultados de nossa pesquisa, quere mos expressar nossos sinceros agradecimentos e tôdas as pes soas e instituições que contribuiram para a realização do presente tra balho, seja por seus emsinamentos, por seus conselhos ou, ain da, por sua colaboração técnica.

Ao Prof. Dr. Viktor Leinz pelo estímulo e pela valiosa orientaçäo dispensada durante a elaboxação do trabalho; ao Eng. Químico filcyr César do Nascimento, chefe da Seção de Agro geologia do Instituto Agronômico do Estado, que gentilimente ce deu os laboratórios de sua seção para a elaboração das análises químicas e análises pelos raios $\mathrm{x}$; a Prof. José Pereira de Quei roz Neto, pelas sugestões apresentadas no decorrer dos traba thos de campo; ao Dr. Franco Levi pelas críticas apresentadas a manuscrito; ao Eng. Agrônomo Elliot Katijama pela microscopia eletrônica, que muito auxiliou na elucidação de certos problerna ; aos Geólogos Vicente A. V. Girardi, Igor Bittencourt e Adilson de Carvalho pelas sugestões apresentadas aos trabalhos de laboratório; ao Dr. Evaristo Ribeiro Filho pela micrografia das sec ções delgadas; ao Sr. Jordão Nepote pela elaboração de análises químicas.

Agradecemos, ainda, à Profa. Srta. Naria de Lourdes Loureiro pela leitura e correção do texto; à Srta. Naria Inês de Paiva e ao Sr. José Ponchirolli pela datilografia e ao Sr. Italo Bello pela impressäo do texto.

Finalmente, é imprescindível que agradeçamos à Fundação de Amparo à Pesquisa do Estado de São Paulo (FAPESP) . sem o auxílio da quà não seria posoível a realização dêste trabalo. 
PRINEIRA PARTE

CONSIDERAGOES GERAIS 


\section{CAPITULO I}

\section{ESTUDO SUCINTO DO NIEIO FISICO}

A região em estudo acha-se situada na parte centro-leste do Estado de Eão Paulo, logo acira do trópico de Capricónnio, es terdendo-se entre os paralelos de $22^{\circ} 39^{\prime}$ e $23^{\circ} 14^{\prime}$ s e osmeridianos de $46^{\circ} 38^{\prime}$ e $47^{\circ} 26^{\prime} \mathrm{Wr} \mathrm{Gr}$. (Fig. 1$)$.

A área total abrangida é de aproximadamente $3.100 \mathrm{~km} 2$.

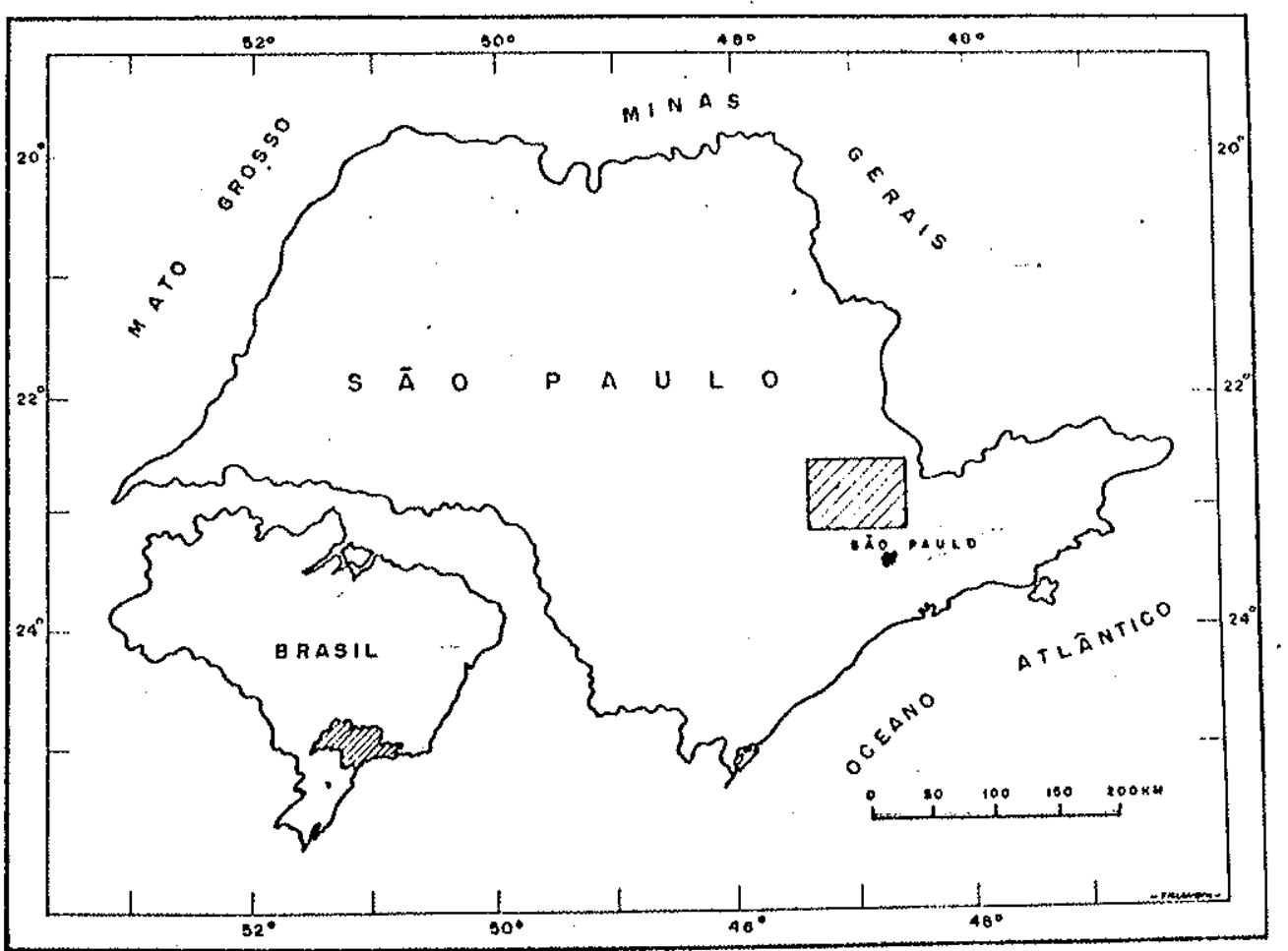

Fig. 1 - Napa de Localização da área estudada

$1-$ Geologia

Geològicamente, a região é constituída por rochas do embasamento cristalino pré-devoniano, por sedimentos perro-carbo níferos pertencentes ao chamado Grupo Tubarão e por rochas ígneas básicas mesozóicas intrusivas nestes sedimentos. Tôdas es- 
tas formações geológicas acham-se parcialmente recobertas pur sedimentes cenozóicos, cuja origem élígada a fenômenoa de pe dimentação (Bjonberg, 1966 e Melfi et al., 1966).

Grande parte da área já foi estudada geològicamente por Melfi e Bitencourt (1962), fundamentando-se a presente pesquisa bàsicamente neste trabalho.

A distribuição das principais unidades litológicas é mos 'trada no mapa geológico anexo (Fig. 2).

Descrição das unidades

a) Complexo Nietamórfico - As principais rochas que constituem o complexo metamórfico são predominantemente gnais ses e micaxistes, quartzitos e filitos subordinados.

Os gnaisses são predominantemente bandeados, com camadas claras (quartzo-feldspáticas) intercaladä com bandas es curas constituŕdas de anfibólios e biotitas. Ao norte, no Nínicí pio de Amparo e ao sul, no de Itu aparecem grandes massas de migmatitos em estreita associąão com os corpos graníticos.

Os únicos corpos de mica-xistos (quartzo muscovita xis to) afloram ao longo do rio Atibaia, no Distrito de Souzas.

Os quartzitos são relativamente raros na região, não cong tituindo faixas contínuas de espessuras apreciáveis, com uma вć exceção no Nunicípio de Amparo. Os filitos possuem seus únicos alloramentos na parte $\mathrm{CW}_{\mathrm{W}}$ da região, no Niunicípio de Itu.

Pequenos corpos anfibolíticos, ora concordantes com a $\underline{g}$ trutura gexal do complexo metamórfico e ora discordantes, aflo- 


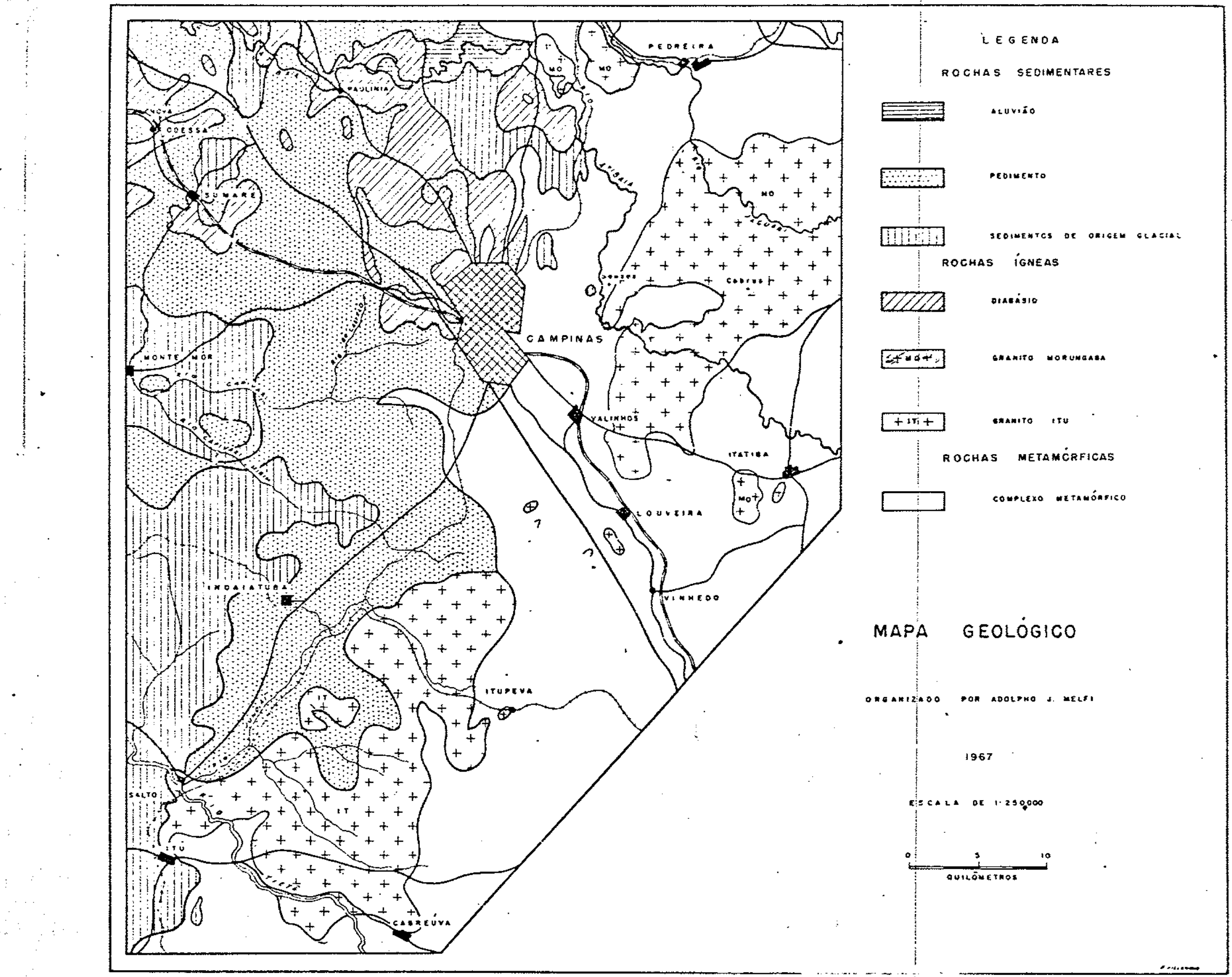


ram ao notte, nos Municípios de Amparo e Pedreiras e ao sul, nas municípios de Itu e Cabreúva.

b) Intrusivas Acidag - Encaixados nas rochas metamórfi cas regionais, afloram corpos intrusivos ácidos que, para efeito de mapeamento, foram separadö er duas uniadeo, Arnbos são granitos típicos, caracterizados pox uma extrema pobreza emmi nerais fêmicos que $x$ axamente atingem un teor de $5 \%$. A porcentagem de plagioclásios é maior nos granitos afloxantes na região de Cabras e Norungaba do que nos afloranter na região de Itu e Valinhos.

Granito Itu - Nos municípiaq de ltu, Valinhos e Indaia tuba ocortem corpos graníticos de textura equigranular grossa. ç̉nstituŕdoo, principalmente, por feldspato potásaico, quartzo e plagioclásio, com biotita subordinada. Apresentam, quando frescos, color ação róbea. Deviclo a. eua pobreza ém minerais fêmicos e ao seu alto teor em feldspato potássico, podem ser classifica dos como alasquito.

A designação de granito Itu, por nós utilizada, é popular no Estado de São Paulo, pois é neote Niunicípio que predominam Eeus afloramento principalmente, na forma de enormes matacões.

Granito Morungaba - Nos Municípios de Morungaba, Pedreira e Campinas afloram corpos de granitos por vêzes porfiroidais que se apresentam orientados paralela ou sub-paralelamente à xistosidade apresentada pelas rochas pertencentes ao complexo metamórfico, eugerindo tratar-se de um granito sin tectônico. 
Sua textura é equigranulax, variando de média a grosea, porém quase sempre mais fina do que o granito tipo Itu. Comu mente apresenta uma textura porfixoidal, com cristai s centimétricos de feldspatos numa massa milimétrica de quartzo e feldspato.

A análise microscópica cividenciou tratar-se de alasuito, semelhante ao anteriox, possuindo, entretanto, um teor ligeira mente mais elevado em plagioclásio. O feldspato potássico é o seu principal constituinte, pexfazendo cêrca de $40 \%$ do volume to tal da rocha. O quartzo é o segundo mineral em abundância, cong tituinclo cêrca de $35 \%$ do volume total. O plagioclúsio aparece for mando por volta de $25 \%$ de seu volume total, enquanto a biotita é escassa, como no granito Itu, raramente atingindo $2 \%$ do volu me total da rocha. Os acessórios podem atingir até no máximo $2 \%$, sendo a titaxita o principal mineral dêste grupo, seguida dos minerais opacos, zircão e apatita.

Associados aos granitos, ocorrem inúmeros diques de gra nitos pórfiros e algurs de lamprófixos, que já mereceram estu dos detalhídos por Girardi e Bittencourt (1963) e Wrernick (1966).

c) Sedimentos da Bacia do Paraná - Na parte oeste da á rea mapeada ocorrem bedimentos permo-carboníferos de origem glacial, flúvio-glacial e lacustre-glacial, pertencentes ì base da Bacia Sedimentar do Paraná. Apregentam-se, via de regra, re cobertos por uma camada relativamente fina de bedimentos cenozóicos, aflorando sòmente nas zonas onde a rêde de drenagem en talhou mais profundamente o terxeno, como acontece ao longo dos 
vales do Tietê, Capivari e Capivari Nirim. São, principalmen. te, sedimentos clásticos finos, siltitos e argilitos ascociados a tilitos e conglomerados subordinados. E notável a ausência de se dimentos arenosos na região.

Os siltitos e argilitos, têrmos litológicos predominantes, são encontrados na região de Itu, Indaiatuba e Nionte Nior. Os ti litos e conglomexados ocorrem em afloramentos esparsos na re gião de Salto e Tanquinho, em contato com o fundo irregular da bacia formado pelo embasamento cristalino.

A existência de manchas isoladas de sedimentos permo carboníferos em terrenos pré-devonianos, descritas por Niartin et al. (1959) e por Melfi e Bittencourt (1962), mostram maior extensão para leste das rochas de Grupo Tubarão, atualmente erodidas.

d) Intrusivas Básicas - Os diabáoiós constituem as ro chas predominantes na parte noroeste da região estudada, ocor.rendo na forme de sills intrusiyos nos sedimentos permo-carboníferos ou no contato dos sedimentos com rochas mais antigas pré-devoniañs. São roches escuras, tendendo para o prêto, com granulaçño variável, fina nas zonas periféricas dos corpos intrü sivos e grossa na parte central dos grandes corposígneos. Atex tura é cm geral sub-ofítica, podendo ocorrer ainda a ofítica, a porfirítica e mais raxamente a intersctal. No município de Paulínea, na extromidade noxte do granre sill de Campinas, o intercrescimento de quartzo e folcipoto potáasico é de tal intensidade que empresta à rocha urn carráter granofírico. 
A composição mineralógica varia pouco de afloramento para afloramento, sendo o mineral mais abundante o plagioclásio, que constitui geralmente cêrca de $50 \%$ do volume da rocha total.

O segundo lugar em inaportância é ocupado pelos piroxênies cujos cristais pertencem a dois minerais do grupo dos clinopiroxê nios: augita, mais abundante, e pigeonita, subordinada. Ambos constituem cêrca de 35 a $40 \%$ do volume total da rocha.

Og acessórios, que em casos extremos atingem o máximo de $15 \%$ do volume total, são, principalmente: magnetita, ilmenita apatita. Quartzo, olivina e feldepato potásaico podem aparecex eqporàdicamente em determinados afloramentos, podendo ainda ocor rer biotita.

Com base nos recentes estudos geocronológicos efetuados no Centro de Pesquisas Geocronológicas da Univiversidade de São Paulo por Amaral et al. (1965), e Melfi (1967), êstes corpos ígroos intrusivos podem sex considerados de idade Cretácea inferior, cor relacionáveis a do vulcanismo básico que afetou todo o Brasil meridional.

c) Sodimentos cenozóicos - Recobrindo parte dos sedimentos permo-carboníferos do Grupo Tubarão, parte dos diabásios e parte das formações pré-devonianas, temos uma camada detrática por vêzes espêssa, caractexizada pela incoerência de um matexial mal selecionado, sem estratificação visível. Em seu contato com as formaçöes inferiores, é frequente a existência de linhas ds seixo de espessura variávcl, como ficou dernonstrado no trabalho de Melfi et al (1967). 
Esta bedimontaço capeia marcanteo superfícico aplaina das e está ligada genèticamente a procésoos desenvolvidos em clima semi-árido, com transporto rolativamente pequeno e nas proxi midades de zonas montanhosas. Estas características são típicas de depósitos de pedimentação. Bjornberg (1966), Bjornberg e Landim (1966), e Naclfi ot al. (1966) discutixam recentemente essas ca racterísticas na região.

\section{$2-\underline{\text { Relêvo }}$}

A área em estudo apresenta uma xnorfologia complexa, abrangendo duas regiöes naturais; o planalto Atlântico e a depres вão pexiférica. Planalto Atlântico

Almeida ( $1 \rightarrow 64)$, baseado na grande heterogeneidade estru tural da qual resultam formas topográficas divexsas, dividiu o pla nalto Atlântico em 10 zonas, das quais duas são, em parte, abran gidas pela região oxa analisada: a) sexrania de São Roque e b) zona cristalina do norte.

a) Serrania de São Rogue - Corresponde a uma estreita fai xa que ocorre no sul da áxea, formando um planallo onde as maio / res elevações alcançan $1.200 \mathrm{~m}$ de altitude, enquanto seus vales mais baixos estão em cotas nunca inferiores a 600 metros.

E constiturda essencialmente pox granitos e gnaisoes. O granito do tipo não porfírico, rosado, aflora continuamente de sde Cabreúva até o sul do Niunicípio de Campinas. Este grande batóli to forma no extremo meridional da árca a maior expressĩo topo - 
gráfica da zona dentro da regiano estudada: a serra de Itaguá, quo serve de limite norte para a serrania de São Roque, separando-a. da zona cristalina do norte.

Todo o relêvo nesta região vai gradualmente perdendo altura de leste para oeste, pasando de 1.200 metros na serra do Japi, para 1.000 metros na sorra da Itaguá, continuando a dimi -: nuir até desaparecex sob as rochas sedimentares do Grupo Tubam. rão.

A rêde de drenagem mostra-se oubordinada à estrutura geológica. Oo dois principais rios que atingem a ároa, o Tietê e - Jusdiar, apresentam claramente esta tendência; o Tietê está adaptado às direcöes estruturais NNE e NW apresentadas por gra nitos e xochas metamóxicas e o Jundiaí, ao contato geológico en tre as rochá prémdevonianas e os sedimentos da Bacia do Paraná.

b) Zona cristalina do Norte - Guase tôda a totalidade do planalto Atlântico na região pode ser enquadrado dentxo da zona cristal ina do Norte.

Aprescrita un relêvo montanhoso com as máiores altitu dea não ultrapassando a $\$ 200$ metros, condicionadas pela superfície de aplainamento de Itaguá, aeguado Almeida (1964). Essta altitude oó é atingida na serra das Cabras, a leate do Município de Carnpinas.

Geològicamente, predominam gnaisses o granitos commi caratos e quartzitos qubordinados. As maiores expresoñes topográficas dá área, as serira de Cocais c das Cabras, constituí - 
das de granitos, apresentam uma moxfologia que constrasta com o relêvo da regióes vizinhas, coculturad em gnaissen e mica xistos, formando um nível altimétrico mals baixo, de apxoximadamente 800 metros (Fig. 3). O tôpo e as vertentes destas ser ; xas estão coalhadas de matacões, que emprestam à área um as pecto bastante peculiax.

Os principais rios da região são: Atibaia, Jaguari e Jundiar. O Atibaia e o Jaguari cortam as principais estruturas NE transversalmente, de forma superimposta, o que ê uma caracte rística da drenagem de todo o planalto; aproveitam, nos grani tos, as linhas de fraquezas, formando uma rêde de drenagem or togonal e concoxdando eventualmente com a xistosidade e guaissi ficação das rochas metamórficas. O Jundiaŕ, como na área ante rlor, acompanha o contato rochas pré-devonianas - scdimentos. que se efetua na direção NE.

Depressão Periférica

A expressão depresã̃o periférica, criada por Nioraes Rego (1932) é ainda mantida porque se enquadra perfeitamente dentro do aspecto da $x$ egião. ras altas do planalto Atlântico e as crista elevadas das cuestas basálticas.

Almeida (1964) adotou uma subdivisão para a depressão periférica, em três zonas: do médio Tietê, do Paranapanema $\in$ do Niogi-Guaçu, estando a região estudada totalmente compreendida dentro da zona do médio Tietê.

A zona do médio Tietê é conotituída parcialmente por sem 
dimentos do Grupo Tubarão, com impoxtantes intrusõos de diabá sio, que na forma de sills desempenham papel relevante na topografia.

De um modo geral a topografia é pouco acidontada, com desníveis que raramente ultrapassam 100 metros, predominando - relêvo em colinas arredondadas de bordos convexos,

Os locais onde aflora o sill de diabásio, apresentam for mas peculiarea de topografia, em contraposiçäo ao relêvo oferecido pelos sedimentos cixcunvizinhos. Tais formas se caracterizam por tôpos planos, rupturas de gradiente mais acentuadas e. concavidade geral das encostas (FIg. 4).

As altitudes médias estão por volta de 600 metros, raramente atingindo valôres maiorer, com'exceção das regiões onde afloram corpos de diabásio de grande porte, podendo aí atingir al titudes auperiores a 700 metros, como ocorre na cidade de Cammpinas, no bairro Chapădão.

A drenagem da região é feita pelos rios Atibaia, Jaguari e Tietê, possuindo todos êles nesta faixa, dirę̧ão geral NW, a companhando o pequeno mergulho dos sedimentos.

A rêde de drenagem, que é abundante nos sedimentos de origem glacial, torna-se bastante restrita nas áreas recobortas por material de pedimentação, em virtude da grande porosidade decorrente de seu mau selecionamento.? 


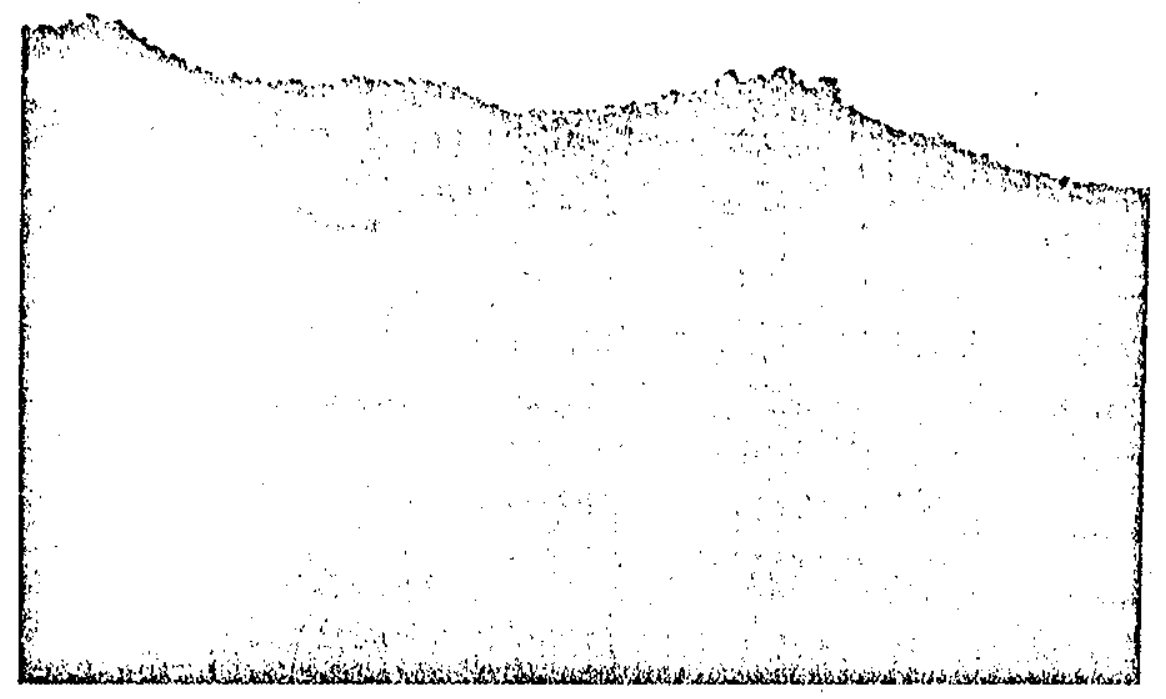

Fig. 3 - Relêvo característico da região de contato entre grani tos e mica-xistos.

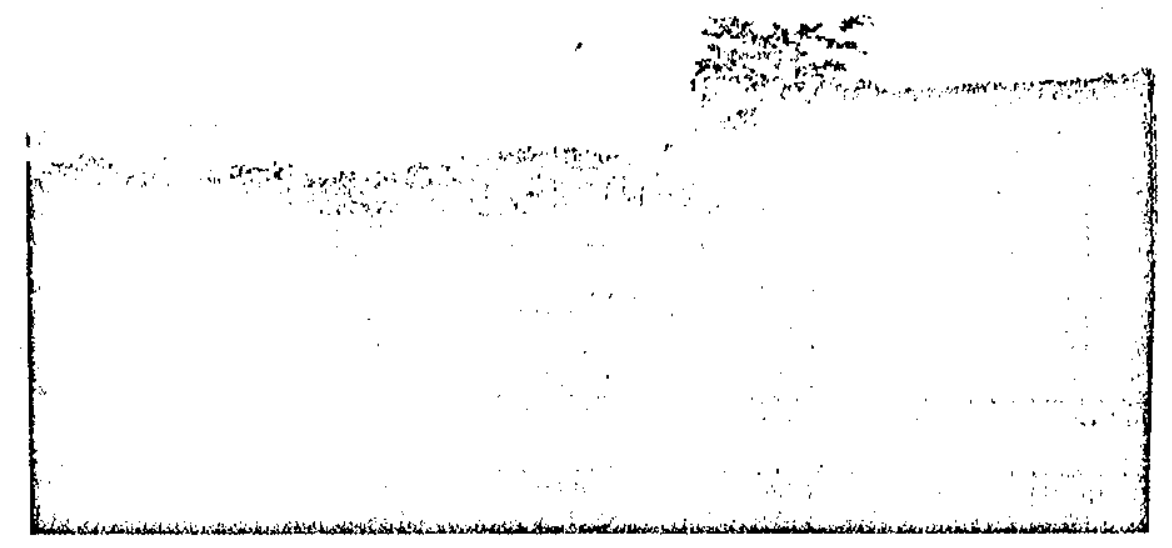

Fig. 4 - Forma típica do relêvo formado pelos coxpos de diabásios. 


\section{$3-$ Clima}

Os agentes climáticos que realmente exercem oarol prẹon derante nos fenômerca intempéricos c pedogenéticos são: água e temperatura, como muito bem ficou demonstrado nos trabalhos de Geoffe (1936), Demoion (1952), Segalen (1757), Aubert (1357) e Douchaufour (1960).

- A temperatura crescente favorece a velocidade das reaçoses de hidratą̧ão dos íons, e sua solubilidade, favorecendo o aumento de material que fode passar para o estado dissolvido. Facilita ainda a troca iônica entre íons carregados pela solução e os situados nas estruturas cristalinas.

A água age de maneira cornolexa, pois, além de retirar ma texial solubilizado, pode conter substâncias dissolvidas anterior mente. Estas podem intensificor a ação intempérica ou contribuir com partículas que são adsorvidas e incaxporadas a material sóli do.

Comumente, êstes dois agentes climáticos são analisados a partix de dados da climatologia clásoica, que por øi só, têm um va lor relativo, pois realmente o que interessa é conhecer como a água e a temperatuxa agem no solo ou na rocha, isto é, conhecex o clima do solo.

Wiohr e Van Baren (1954) mostraram que o clima do solo é condicionado pelos valores do clima atimostérico (água e tomperatura) e pelas radią̧oes soiarce cue atingem a superfície. Aágue do solo depende não só da quantidade de água precipitada, cono também dr ovaporajão gue, por sua vez, depende de outros fatô - 
reo atmosféricos.

Entretanto, corno as informaçöes diretas sôbre o clima do solo são muito cscassas, e pelo fato dêsto depender do clima atmos férico, podemos, atxưvés do estudo de seus elementos componentes - dos fatôres que intervêm para modificá-los (vegotą̧ ẽo e relêvo). inferir alguns dados que possam sox de grande atilidads para o con nhecimento do clima do solo.

\section{Regime térmico e Pluviométrico}

No estudo climático da b́xea utilizamos dados inetaoxológi cos obtidos em nove estąöes localizadas dentro ou nas cercanias da região estudada.

A) Erecipitąão - em zonas situadas nos limites dos trópicos, a precipitạ̃a ão torna-se o elemento climático mai s importante para a análise do intemperismo das rochas e dos solos ( 3 chroedar, 1956).

Pelo mapa de isoietas do Estado de São Faulo, apresentado por Schroeder (1956), verifica-se cue a pluviosidade aumenta para leste, passando de valore 3 de $1.100 \mathrm{~mm}$ na região de Itu para valores aproximados de $1.500 \mathrm{~mm}$ na região da serra dos Cristais; esta funciona como una barreira interceptadora das rassan de ar que se deslocam de leste para oeste, forçando-as a descarregar aísua umidade.

A tabela 1 apresenta as médias mensais de precipitą̃ão temperatura de cinco localidades aituadas na área e otudada, asoim como outras ouatro situadas nas vizinhanças. 
TABELA 1

Médias Miensais de Temperaturas e Precipitaçōes

LOCALIDADE Jan Fev Mar Abr Mai Jun Jul Ago Set Out Nov Dez anual

\begin{tabular}{|c|c|c|c|c|c|c|c|c|c|c|c|c|c|c|}
\hline 10 anos & $\frac{\text { Americana* }}{\text { Cwa }-530 m}$ & 184 & 199 & 136 & 52 & 35 & 29 & 18 & 26 & 78 & 125 & 154 & 238 & $1274 P$ \\
\hline 5 anos & Cfa-Cwa-o70m & $\begin{array}{l}23.0 \\
308\end{array}$ & $\begin{array}{l}23.1 \\
202\end{array}$ & $\begin{array}{c}22.3 \\
153\end{array}$ & $\begin{array}{c}20.4 \\
72\end{array}$ & $\begin{array}{c}17.7 \\
51\end{array}$ & $\begin{array}{c}16.2 \\
63\end{array}$ & $\begin{array}{c}15,6 \\
40\end{array}$ & $\begin{array}{c}17,5 \\
31\end{array}$ & $\begin{array}{c}19.3 \\
69\end{array}$ & $\begin{array}{l}20.4 \\
100\end{array}$ & $\begin{array}{l}21.8 \\
153\end{array}$ & $\begin{array}{l}22.7 \\
225\end{array}$ & $\begin{array}{l}20.0 t^{\circ} \\
14672\end{array}$ \\
\hline 1 anos & $\frac{\text { Cabreúva* }}{\text { Cfa-bsom }}$ & 279 & 173 & 140 & 72 & 57 & 65 & 35 & 48 & 95 & 104 & 143 & 230 & $1441 \mathrm{P}$ \\
\hline 36 anos & $\frac{\text { Campinas } *}{\text { Cwa }-670 \mathrm{~m}}$ & $\begin{array}{l}23.1 \\
241\end{array}$ & $\begin{array}{l}23.0 \\
217\end{array}$ & $\begin{array}{l}22.7 \\
144\end{array}$ & $\begin{array}{c}20.7 \\
62\end{array}$ & $\begin{array}{c}18.5 \\
49\end{array}$ & $\begin{array}{c}17.2 \\
41\end{array}$ & $\begin{array}{l}17.0 \\
24\end{array}$ & $\begin{array}{c}18.7 \\
33\end{array}$ & $\begin{array}{c}20.2 \\
56\end{array}$ & $\begin{array}{l}21.1 \\
128\end{array}$ & $\begin{array}{c}21.8 \\
138\end{array}$ & $\begin{array}{l}22.4 \\
232\end{array}$ & $\begin{array}{l}20.5 t^{\circ} \\
1364 P\end{array}$ \\
\hline 16 anos & $C f_{2}-C_{\text {Cwa }}^{\text {Itu* }}-570 \mathrm{~m}$ & $\begin{array}{l}23.5 \\
178\end{array}$ & $\begin{array}{l}23.7 \\
173\end{array}$ & $\begin{array}{l}23.1 \\
108\end{array}$ & 21.2 & $\begin{array}{c}18.5 \\
53\end{array}$ & $\begin{array}{c}17.1 \\
49\end{array}$ & $\begin{array}{c}16.7 \\
35\end{array}$ & $\begin{array}{c}17.5 \\
53\end{array}$ & $\begin{array}{c}19.6 \\
69\end{array}$ & $\begin{array}{c}21.0 \\
88\end{array}$ & $\begin{array}{c}22.1 \\
99\end{array}$ & $\begin{array}{l}22.4 \\
109\end{array}$ & $\begin{array}{l}20.5 t^{\circ} \\
1152 \mathrm{P}\end{array}$ \\
\hline $\begin{array}{l}37 \text { anos } \\
18 \text { anos }\end{array}$ & $\frac{\text { Jundiaí }}{C f b-C f a-730 \mathrm{~m}}$ & $\begin{array}{l}21.7 \\
268\end{array}$ & $\begin{array}{l}21.9 \\
216\end{array}$ & $\begin{array}{l}21.1 \\
139\end{array}$ & $\begin{array}{c}19.9 \\
64\end{array}$ & $\begin{array}{c}17.7 \\
58\end{array}$ & $\begin{array}{c}16.0 \\
50\end{array}$ & $\begin{array}{l}16.1 \\
37\end{array}$ & $\begin{array}{c}16.8 \\
45\end{array}$ & $\begin{array}{c}18.6 \\
85\end{array}$ & $\begin{array}{l}19.9 \\
114\end{array}$ & $\begin{array}{l}20.6 \\
167\end{array}$ & $\begin{array}{l}21.0 \\
235\end{array}$ & $\begin{array}{l}19.3 t^{\circ} \\
14789\end{array}$ \\
\hline 25 anos & $\frac{\text { Limeira** }}{\text { Cwa }-620 \mathrm{~m}}$ & $\begin{array}{l}22.6 \\
236\end{array}$ & $\begin{array}{l}22.4 \\
210\end{array}$ & $\begin{array}{c}22.0 \\
171\end{array}$ & $\begin{array}{c}20.1 \\
66\end{array}$ & $\begin{array}{c}18.0 \\
4.7\end{array}$ & $\begin{array}{c}16,7 \\
34\end{array}$ & $\begin{array}{c}16.5 \\
22\end{array}$ & $\begin{array}{c}18.6 \\
28\end{array}$ & $\begin{array}{c}20.1 \\
59\end{array}$ & $\begin{array}{l}20.9 \\
125\end{array}$ & $\begin{array}{l}21.4 \\
153\end{array}$ & $\begin{array}{r}21.9 \\
223\end{array}$ & $\begin{array}{l}20.1 t^{\circ} \\
1374 \mathrm{P}\end{array}$ \\
\hline 20 anos & $\frac{\text { Nionte }}{\mathrm{Cwa}} \frac{\text { Alegre**}}{-930 \mathrm{~m}}$ & $\begin{array}{l}22.1 \\
265\end{array}$ & $\begin{array}{l}22.0 \\
220\end{array}$ & $\begin{array}{l}21.5 \\
190\end{array}$ & $\begin{array}{c}19.3 \\
63\end{array}$ & $\begin{array}{l}16.9 \\
48\end{array}$ & $\begin{array}{c}15.6 \\
50\end{array}$ & $\begin{array}{c}15.7 \\
30\end{array}$ & $\begin{array}{c}17.7 \\
32\end{array}$ & $\begin{array}{c}19.8 \\
47\end{array}$ & $\begin{array}{c}20.5 \\
122\end{array}$ & $\begin{array}{l}20.5 \\
152\end{array}$ & $\begin{array}{r}21.3 \\
220\end{array}$ & $\begin{array}{l}19.4 t^{\circ} \\
1439 \mathrm{P}\end{array}$ \\
\hline 14 anos & $\frac{\text { Pedreira* }}{\text { Cfa }-670 \mathrm{~m}}$ & 217 & 204 & 154 & 64 & 46 & 35 & 25 & 32 & 81 & 132 & 166 & 251 & $1413 P$ \\
\hline
\end{tabular}


Os dados de Nonte Alegre do Sul foram tomados para ib cam racterização climática das regiões elevadan de Campinas e Itatiba (serra das Cabras e do Cocais), assim como os de Americana, pa ra a caracterização das regiões de Sumaré e Paulínia.

A análise dos dados fornecidos pela tabela 1 mostra que:

a) as maiores precipitıções ocorrem no mês de janeiro, com excę̆̃a de Amcricana e Pedreira ondc as maiores precipita¡öes foram registradas am dezembro;

b) as precipitações verificadas noo meses de inver \$o são tôdas inferiores a $60 \mathrm{~mm}$, com duas excę̧ôs: Cabreúva, onde, em junho, elas atingem um valox de $65 \mathrm{~mm}$; e Amparo, onde $\mathrm{cm}$ junho, apresentam $63 \mathrm{~mm}$;

c) abril representa o início do período sêco, o qual sê prolonga até setembro, quando novamente a precipitaça vai-se intensificando;

d) pràticamente $50 \%$ das chuva 3 caema durante os 3 meses correspondentes ao verão. O invorno é realmente sêco, com preci pitą̧ōes, raramente alcansando $15 \%$

B) Tempezatura - com relą̧ão ì temperatura, a tabela 1 mostra-nos que:

a) hấ um decréscimo da tomperatuxa de oeste para leste, e das áreas situidae em cotás mais baixas para as situnclas em co tas mais clevadas;

b) nos meseo mais quentes (janeiro e fevereiro) at temperatura é sempre igual ou superior $222^{\circ} \mathrm{C}$;

c) oø mesos mais frios são junho e julho. 


\section{Clasbificnção Climática}

Os dados da temperatura média do ar e da precipitação plum viométrica permitem icientificax o clima da xegião como pextencente ao tipo C na classificaç̃̃ propocta por KUppen (climas úmidos de tomperaturas brandes), onde a temperature do mês mais frio está entre $3^{\circ} \mathrm{C}$ e $18^{\circ} \mathrm{C}$ e a tempcxatura do mếs mais quente está acima de $10^{\circ} \mathrm{C}$

Na região, o tipo C adnzite dois sub-tipos: Cwa e Cfa.

Cwa - apresenta, no mês mais sêco, chuva infẹ̣ior a $30 \mathrm{~mm}$; a temperatura é supexiox $220^{\circ} \mathrm{C}$ no mês mais quente e inferior a $18^{\circ} \mathrm{C}$ no mês mais fria.

Cfa - apresenta, no mês màis sêco, chuva entre 30 e 60 mm; a temperatura média no mês mais quente é supexior a $22^{\circ} \mathrm{C}$ e no mês mais frio, inferior a $18^{\circ} \mathrm{C}$.

No Nunicípio de Jundiar tenx-se uma transiçäo do sub-tipo Cfa para o Cfb, onde a temperatura do mês mais quente nẽo a tinge a $22^{\circ} \mathrm{C}$.

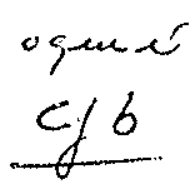

\section{Balanço Hídrico de Thornthwaite}

Sob o ponto de vista do estudo do intemperismo o de peclogenese, deve-se observar que a clessificą̃̃̃o do clima não é suficiente para cefinir as conseculuncias de sua aşão sôbre as roches a so 10s. Precisimos então adotar critérios cue permitam melhor a ava liiş̃o dos fatôros climéticos, principalmente o pluviométrico.

Uma forma ce determina ;õo do balanşo hídrico. Este cálcu- 
10, desenvolvido por Thornthwaite (citado por Camargo, 1961), é baseado no conceito da evipotranspiraço potencial, que é definida como a guantidade de água que retorna à atmosfera através da eva

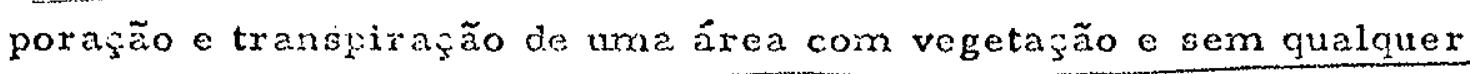
limitaçăo por deficiência de umidade do solo. O balanço hádrico. por êste método, indice não sòmente as deficiências anuais de água, como também os excedentes anuais, ou sejonf a quantidade $\$$ de água fluvial que percolndr para o lenzol freático por efeito da grevidade.

Em vista disso, procuramos mostrax o conportamento do balanço hídrico na região em estudo, analisando o comportamento de trế localidades dentro da região, e mais Amparo e Nionte Alegre do Sul. Os resultados apresentados na tabela 2 , forza clabsra dos com a utilizậa dos dados de precipitacão e temperatura e cálculos de evapotranspiràç̧̃̄o potencial.

A tabeli 2 mostía que a região apresenta um balango hídrico bastante homoĝ̣̣nco, não havendo prâticamente deficit em tôda a ároa, com excezão da zoné noroeste, onde um pequeno deficit po de ocorrer no més de setembro. Oexcedente vai aumentando de oeste para lestc, chegando a alcangar $615 \mathrm{~mm}$ em Nionte Alegre do Sul.

Dos dedos apresentados, infere-se que a região pos bui tal quentidade de água que, durante cinco ou seis meges por ano, mes mo após a evaporagño e o scu aprovsitamento pela vegetąão, ainda sobra um excesso de água que percola pelos solos e rochas promovendo a mobilizaร̃̃o dos seuc elementos. 
$T \wedge B E L A 2$

Disponibilidade de água em mm nos solos, determinada pelo método de Thornthwaite (1948). On númoros com sinal + indicam excedentes de água no mês. Os com sinal - as deficiencias; o os scm sinat, a quan tidade de água disponível no solo.

\begin{tabular}{|c|c|c|c|c|c|c|}
\hline & Amparo & Campinas & Itu & Jundiai & Limeira & $\begin{array}{l}\text { Monte } \\
\text { Alegre }\end{array}$ \\
\hline Janeiro & +191 & +127 & +56 & +164 & +122 & +158 \\
\hline Eevereiro & +97 & +118 & +64 & +122 & +114 & +127 \\
\hline Março & +52 & +43 & +4 & +51 & +73 & +99 \\
\hline Abril & Ih & 78 & 81 & 72 & 76 & 67 \\
\hline Mailo & 57 & 60 & .60 & 57 & 57 & 51 \\
\hline Junho & +10 & 47 & 45 & 43 & 49 & +3 \\
\hline Julho & 42 & 48 & 45 & 45 & 48 & 45 \\
\hline Argôsto & 56 & 65 & 53 & 53 & 65 & 59 \\
\hline Setembro & 72 & -10 & 69 & +3 & -1.8 & 75 \\
\hline Outubro & 85 & 91 & 88 & +32 & 91 & 88 \\
\hline Novembro & +39 & 99 & 99 & +78 & 96 & +29 \\
\hline Dezembro & +110 & +100 & +44 & +165 & +109 & +119 \\
\hline \multicolumn{7}{|c|}{ Balanco Anual } \\
\hline kxcedente & 499 & 388 & 168 & 615 & 418 & 534 \\
\hline Deficiência & 0 & 10 & 0 & 0 & 18 & 0 \\
\hline Procipitação & 1.467 & 1.365 & 1.152 & 1.478 & 1.375 & 1.439 \\
\hline EP potencial & .968 & 987 & 384 & 863 & 972 & 906 \\
\hline
\end{tabular}


$4 \quad-$ Vegetag̃o

Os fatôxes já estudados, responsáveis pelo intemporismo ou pela formąão dos solos constituem as variáveis indspendentes. A ação da vegetaş̃̃o, entretanto, é muito complexá neste arpecto, pois ora assumo câractexística de ma variável dependente, ora de uma variável independente.

A vegetação pode agir dixetamente através da penetrą̧̃o das raízes que produzem efeitos mecânicos; ou pelas substâncias que excretan ou absorvem, produzindo efeitos físico-cuímicos. Po. de agir indiretamente no intemperismo, controlando a arzo dos agentes climáticos, diminuindo normalmente ceu potencial erosivo e reduzindo a amplitudes das varią̧ões de temperatura e umida de, além de criar condiçōes para a atividade biológica.

A anélise de sua atua jão sôbre os solos é feita, em geral. através da qualidade da metéria orgânica formada, e pela influência que cada tipo de cobertura vegetal exerce sôbre o clima da superfície e do interior dos solos. Os txabalhos realizados por Geof fe (1936), Soil and Man (1938), D'Hoore et al (citado por Aubert, 1961) e Da Costa e Godoy (1962), salientam muito bem êtes aspec tos.

Na região em estudo, à observą̧̃o da influência da vegeta fão apregente corta dificuldade, devido ao fato da utiliza zão agrí cola da área ter provocado a eliminą̧ão quase total da cobertuxa vegetal primária, pois a ą̧ăo do hornem be fề sentir por tôda a parte, mesmo onde as terras eram mais fracas e recobertas por cerrado. Tentaremos neste capítulo reconstituir a vegetą̧̃o pri - 
mitiva, com base nos poucos testemunhos existentes para permitix o estabelecimento de suas influências sôbre o solo.

Do ponto de vista da distribuição dos tipos de vegetação, en contramos duas áxeas típicas bem delimitadas: uma maior, dominando pràticamente tôda a região, e constituŕda por testemunho de um tipo de vegctą̧̃o floresta (Fig. 5); c outra menor, restrita à parte ocste dá área, constituŕda por vegetą̧ão de cerrado (Fig. 6).

Dentre as fomaçoos florestais distinguem-se dois tipos: a floresta latifoliade tropical e a floresta tropical latifoliada semide cídua (C. N.S., 1960).

Floresta latifoliada tropical - é a mais importante forma. ६ão vegetal do Estado de São Paulo. Arvores de 30 metrò de al. tura, troncos grossos, ausência do aspecto úmido consequente da menox procipitąão e grande variedade de representantes das fa milias das luguminosas, são as características principais desta formą̧ão vegetal.

Este tipo de formą̧̃̃o vegetal ocorre na área, associada à terra roxa legítima (1r.tossolo roxo). Esta uniảade pedológica caractexian-se por apresentor pexfis profundos, com predominân cia de textura argilosa, e com capacidade de retenção de água na época das sêcas.

\section{Eloresta latifoliada tropical senaidecídua - é menos densa} a menos exuberante do que a primeira. Caracteriza-se por uma perda parcial dos folhas na estaģão sêcat, em consequência dos ao los que a sustentam apresentarem textura mais arenosa que os 


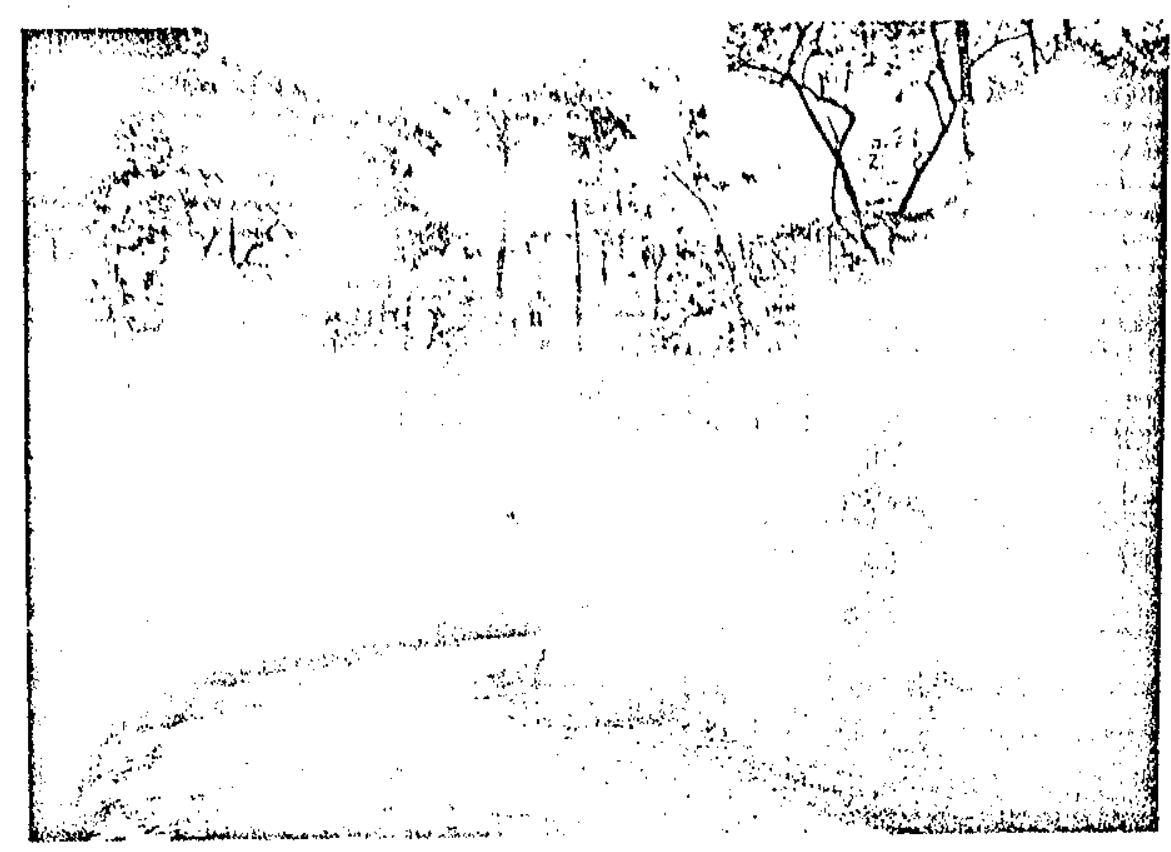

Fig. 5 - Fisionomia da floresta latifoliada eropical no Muni cípio de Campinas (Foto I. A.C.).

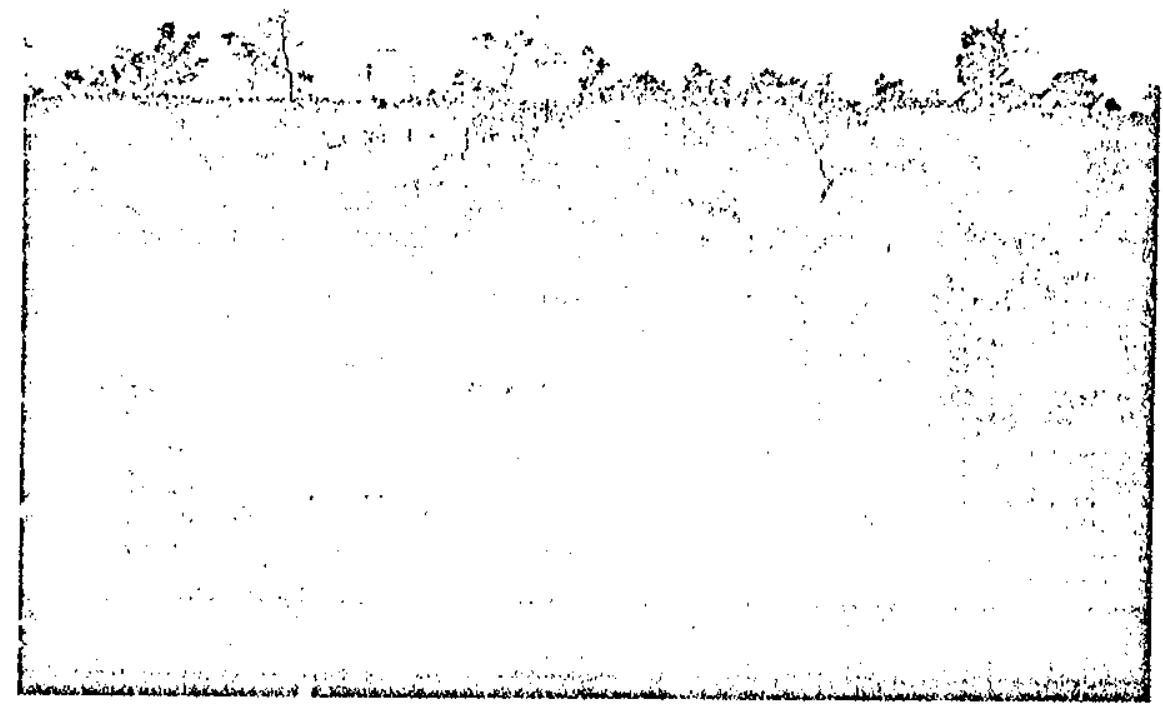

Fig. 6 - Aspecto da vegetasão de cerrado nas proximidades de Viracopos, Campinas (Foto I. A.C.). 
primeiros e possuirem pequena capacidade de rotenção de água.

As árvores apresentam porte menor, alcançando no máximo alturas que variam de 20 a 25 metrog e seus troncos E⿱艹o mais finos, com diâmetros nunca ultrapassando 40 centímetros.

Eiste tipo de vegetaçăo estáa ssociado ace sulos ciobenvol. vidos sôbre rochas do complexo cristalino, mapeados como pod zólicos com cascal ho e podzólicos vermelho-amarelo.

\section{Relacões entre vegetação e solos}

As formações florestais são as únicas que nos interessam, pois nossos estudos dizem regpeito aos solos que as sugtentam.

Estas formações vegetais apresentam uma dinâmica e um ciclo vegetativo relativamente simples. Os elevados valóxes da

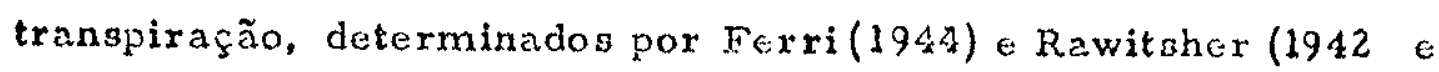
1944) indicam um grande consumo de água contrabalançado por :-quela que o solo armazena de maneira eficaz nos meses de plavio sidade elevada.

A terra roxa legítima, que é um golo bastante argiloso e que possui satisfatória retenç̃̃o de água, pode suportar umá flo resta latifoliada, enquanto que nas mesmas condições climáticas, solos mais arenosos, como os podzólicos com cascalho, provocam o aparecimento da floresta tropical latifoliada semidecídua, pois possuem menor capacidade de retenção de água.

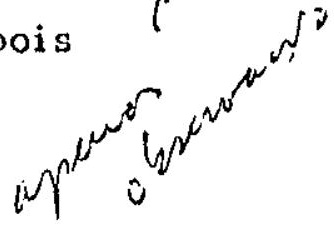




\section{CAPrTULO II}

OS SOLOS

Em virtude de limitarmos nossas pesquisas ao estudo da alteração meteórica das rochas ágneas ácidas e básicas, trataremos neste capítulo sòmente dos solos desenvolvidos sôbre êstes dois tipos de rochas, situando apenas para efeito de mapeamento as unidades pedológicas formadas a partir dos outros materiais e xistentes ne área.

Os solos formados sôbre as rochas graníticas, e denominados pela Comises̃o Nacional de Solos (1960) de solos podzoliza dos com cascalho, ocupam uma área de 2, 2\% do Estado, sendo a região en estudo a que apresenta maior concentração dêstes so$\operatorname{los}($ Fig. 7).

Cs solos desenvolvidos sôbre as rochas básicas, foram designados pela Comissão Nacional de Solos (1960), de terra ro xa legítima. Ocuparn uma área de $11 \% \%$ da área total do Estado (Fig. 8) e formam-se indistintamente a partir de basaltos e de dia bésios. Esta xegiño é a moi s representativa dos nolon desenvolvi dos sôbre dizbrasios.

Cnze pexfis de alteraf̧̃o, coletados pelo autor e pela Sec fĩo de Angrogeologia do Instituto Angronômico do Estado, foram es tudados mineralógica e químicamente com a finalidade de determi nar-se o comportamento do intemperismo e a gênese dos solos ne. região de Campinas. Tendo sido verificada similaridade mineraló gica e química entre alguns perfis formados söbre o mesmo tipo de rocha, apresentamos no prescntc trabalho sòmente o resultado 


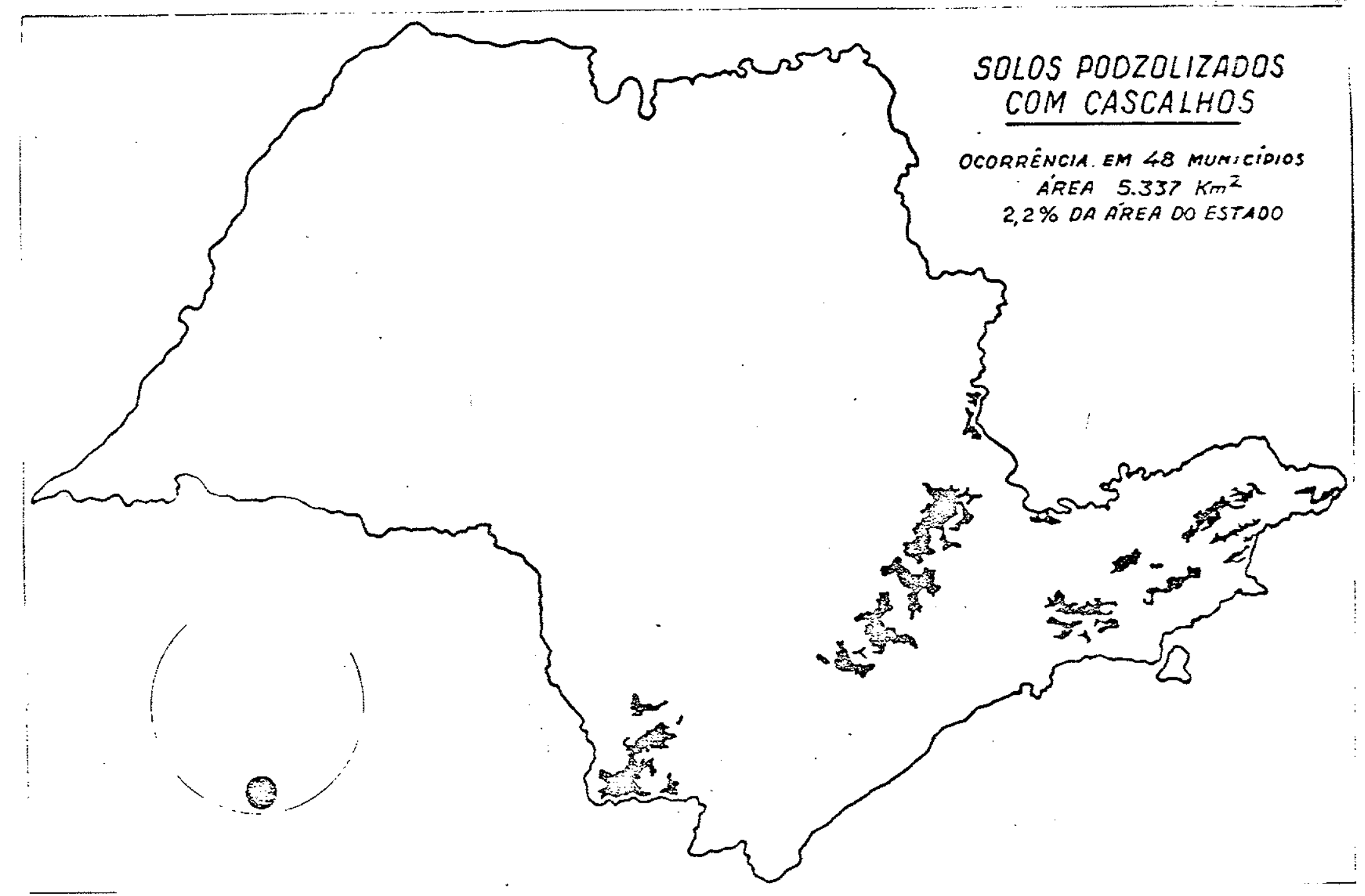

Fig. 7 - Mapa de localizag jo dos solos podzolizados com casc三lis Estado de $S_{\text {à̃o }}$ aulo. 


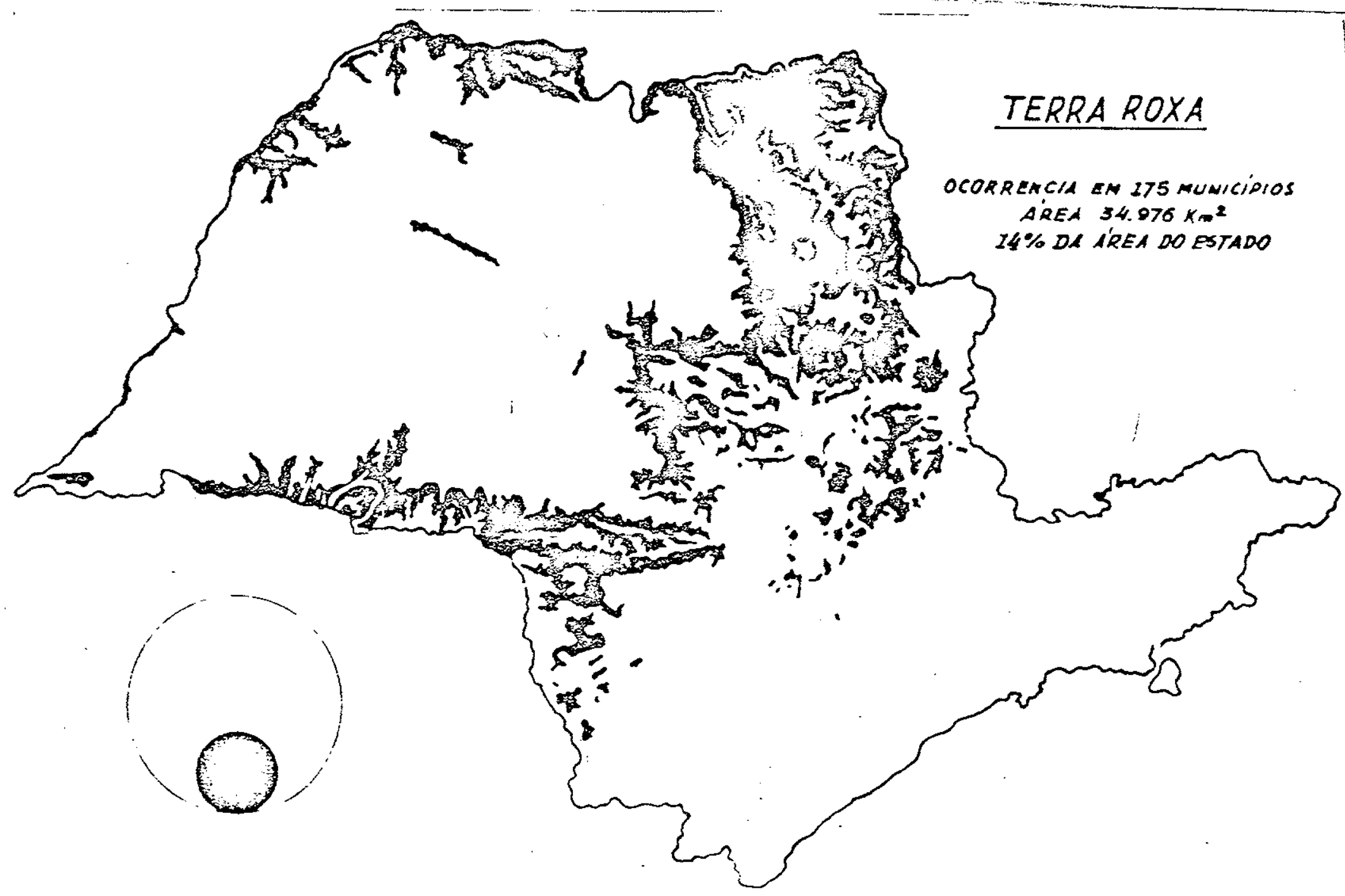

Fig. 8 - Mapa de localizaçäo das Terzas roxas legítimas no Estado de São Paulo. 
de selo dêles, considerados representativos para a área.

O mepa de scios da regiăo (Fig. 9) difere em muitos pontos daquelo apresentado no levantamento de reconheciracnto dos solos do Estado de São Paulo, levado a efeito pela Comis são Na cional de Solos (1960), principalmente na zona oeste: aŕ, pelo fa to de não ter sido observada uma extensa camada de sedimentos modernos que recobre parcialmente os sedimentos de origem gla cial, os diabásios e as rochas pré-devonianas foram colocados sob uma mesma legenda solos diferentes formados a partir de ro chas diferentes ("regosol intergrade para latosol vermelho-amare $\left.10^{\prime \prime}\right)$.

No mapa de solos, para denominarmos as unidades ma peadas, utilizamos, com algumas modificações, a classificeção proposta por Thorp and Smith (1749), classificação esta já utiliza da pela Comisa ão Nacional de Solos quando do levantamento dos solos do Estado de São Paulo.

1 - Solos desenvolvidos sôbre granitos

Os dois diferentes tipos de granitos da área apresentam comportamento uniforme no que diz respeito ̀̀ maneira de se in. tcmperizarem. Ambos formam um único tipo de solo, denomina do solo podzolizado com cascalhos (C.N.S., 1960).

Estes solos õ̃o caracterizados por sua pouca profundidade, drenagem boa ou moderada e espessura por volta de 1,50 me tros. Apreventam cascaihos ao longo de todo o perfil, sendo os horizontes fàcilmente sẹparáveis tanto pela côr como pela toxtaxa. 


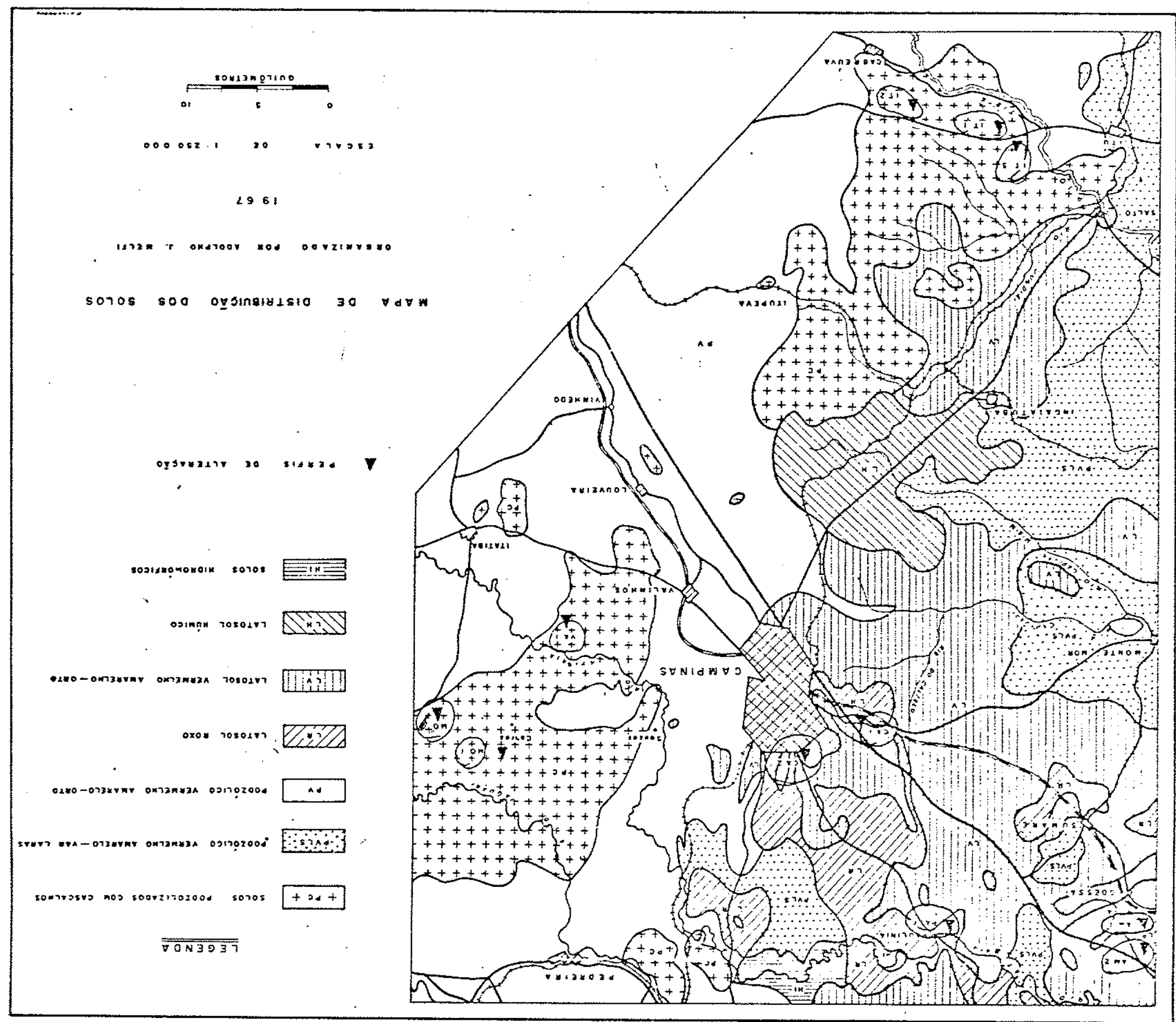


Desde o início do intemperismo a rocha granítica, que dá origem a êste tipo de solo, desagrega-se completamente em sas . constituintes, principalmente em virtude de haver uma porcenta gem muito alta de material estável e resistente. O material formado é rico em fraçöer grossas, conatituídas essencialmente pox quartzo e feldspato potéssico. Essa individualização iniclal de geus componentes não significa que a rocha tenha sofrido a ação de intenso intemperismo físico, como à primeira vista podexia parecer, pois ne região não existem condições que pudessem pro vocar tal desagregação. Esta individualização está ligada a processos químicos incipientes, relacionados com a textura grossa dos granitos e com a quantidade de material resistente à ação do intemperismo.

Anal isando o material totalrnente desagregado, notamos que o intemperismo químico causou certas modificações, princl palmente nos plagioclásios e feldspatos potássicos. Os plagioclá sios tornarr-se foscos e, por vêzes, pulverulentos, enquanto que os feldspatos potáasicos apresentam-se mais ou menos fraturados, sem perder no entanto sua dureza. Este aspecto correspon de a uma perda relativanente pronunciada da coesão da rocha. A biotita, nestes primeiros estádios de alteração, sofre multo pouco a ação do intemperismo. Sua coloração torna-se às vêzê mais amarelada, chegando, em alguns casos, a apresentar-se pràticamente incolox. O quartzo não mostra sinal nenhum da aç̃̃o do intemperiumo.

A êste tipo de matexial, os geólogos dão o nome de gal- 
bro. O processo que provoca sua formą̧̃o tem sido frequente mente denominado, por geólogos e pedólogos europcus, arenizas.̃̃o.

A arenização é uma feição típica da ação do intenoporis mo sôbxe rochas graníticas em climas tempezados. No saibro, ao lado das frações grosseiras, há a formação de material argiloso, principalmente por síntese, mas em proporção extremamen te baixa como bem evidencia Collier (1961) em seu trabalho sôbre a alteração de granitos em países temperados; neste estudo apre senta diversas análices granule métricas de saibros, mostrando que o teor em argila não ultrapassa a $5 \%$ e o teor em limo está por volta de $5 \%$.

Em regiões de climas tropicais e sub-tropicais o fenôme no é similar, mas quase sempre está associado a granitos de gra nuleção grosia, como os que ocorrem em nóssa área. Nestas re giões, pelo fato de existir mais água e a temperature ser supe rior àquela encontrada em regióes de clima tempexado, o saibro vai necessàriamente possuir um teor mais elevado em argila, se bem que raramente ultrapasse $10 \%$.

Curioso é notar que nestas regiões graníticias é comuma presença de blocos de rocha totalmente fresca, envolvidos por material totalmente decomposto (Fig. 10).

A existência de voçorocas associadas a êste tipo de mate rial é uma feiça bastante comum para esta região, pois o sai bro, sendo um material nrenoso, sofre fácil erosão supexficial (Fig. 11). 
(1)

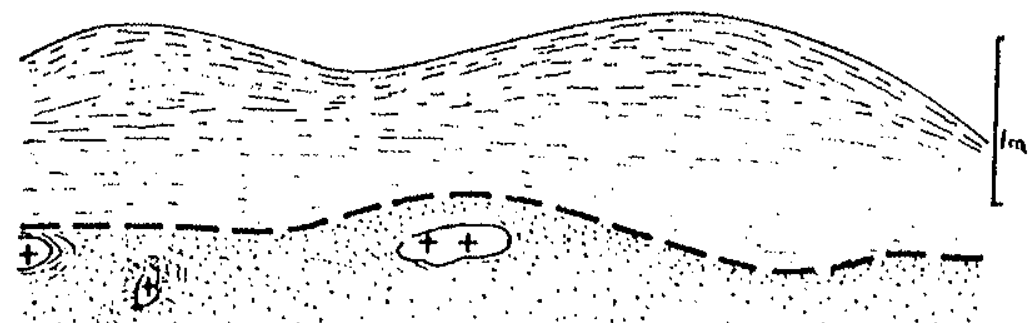

(11)
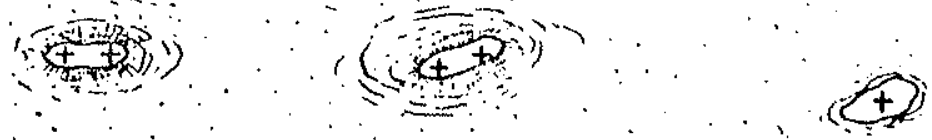

$\because$
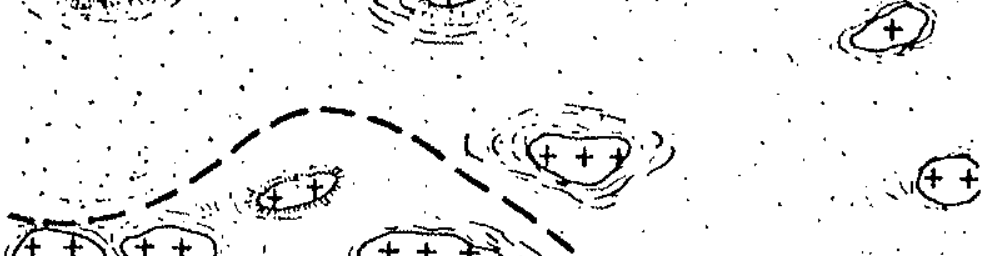

(iii)
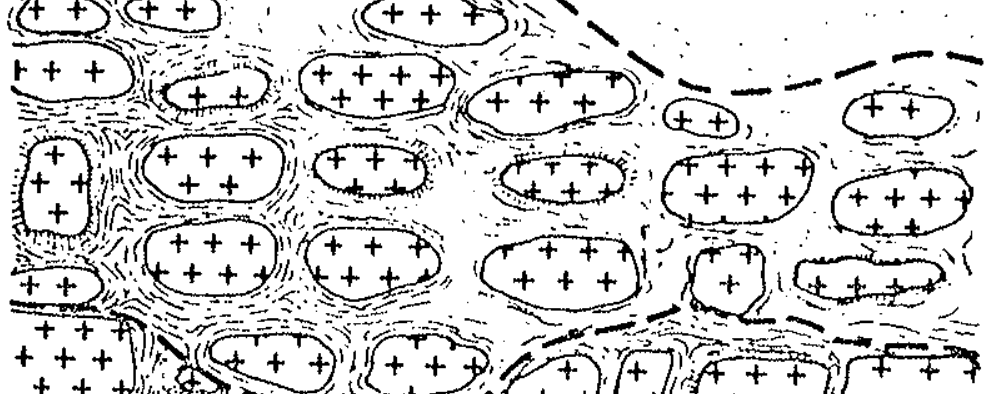

(iv)

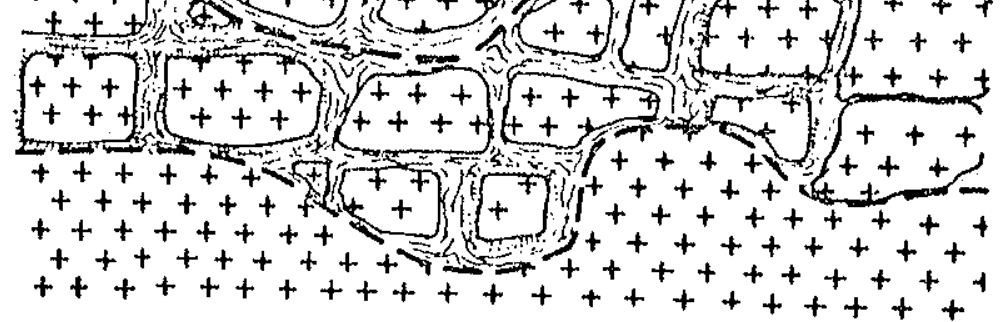

Fig. 10 - Perfil esquemático mostrando a típica alteração do granito.

I - Solo, horizontes A e B.

II. - Saibro, horizonte C. Rocha totalmente de composta, com blocos parcialmente alterados.

III - Rocha parcialmente alterada. Blocos com capa do alteraçã̈, evidenciando decomposi ção esferoidal.

IV - Rocha bastante diaclasada, notando-se $\mathrm{cm}$ alguns blocos a presença de capas concên tricas de alteraçẽo. A maior parte dos blo $\cos$ näo so apresentam aincla arredondados.

$V$ - Rocha totilmente fresca. 
Nos solos hidromórficos desenvolvidos a partir de granito, extremamente restritos na árua e sem expressão para que possam sex mapeados como uma unidade, o processo de areniza ç̃o desenvolve-se do maneira semelhante. Porém, possuimos es cassas informações a respoito da intensidade do fenômenos, pois em nenhum perfil etingimos a rocha fresca originel.

Depois do desenvolvimento do saibro, há o inŕcio da intẹ ração dos processos pedológicos com os do intemperismo. A sim ples observação do perfil de alteração sugere a importância de processos pedogenéticos no material desenvolvido a partir do sa bro; é o solo pròpriamente dito (Fig. 12).

2 - Solos desenvolvidos sôbre diabásios

Os diabásios apresentam comportamento bastante uniforme quanto à maneixa de se intomperizarem." Formam um único tipo de solo, denonainädo pela Comissão Nacional de Solos (1960) terra roxa legítima. São os típicos latossólicos da classificação proposta por Thoxp and Smith (1949) ou solos ferralíticos da classificação proposta por Costa Azevedo (1953) e Aubert (1954). O têrmo ferralítico tem sido usado largamente para evitar o uso do têrmo latossolo, proposto por Kellog (1949) para designax os solos desenvolvidos am regiões tropicais e que se formavam por processos semelhantes zo da formação de lateritas, isto é, por latexização. Na realidade, grande parte dos latossolos nada têm! em comum com o procenso de laterizeção.

Os bolos ferralíticos a ão caracterizados por serem fre m 


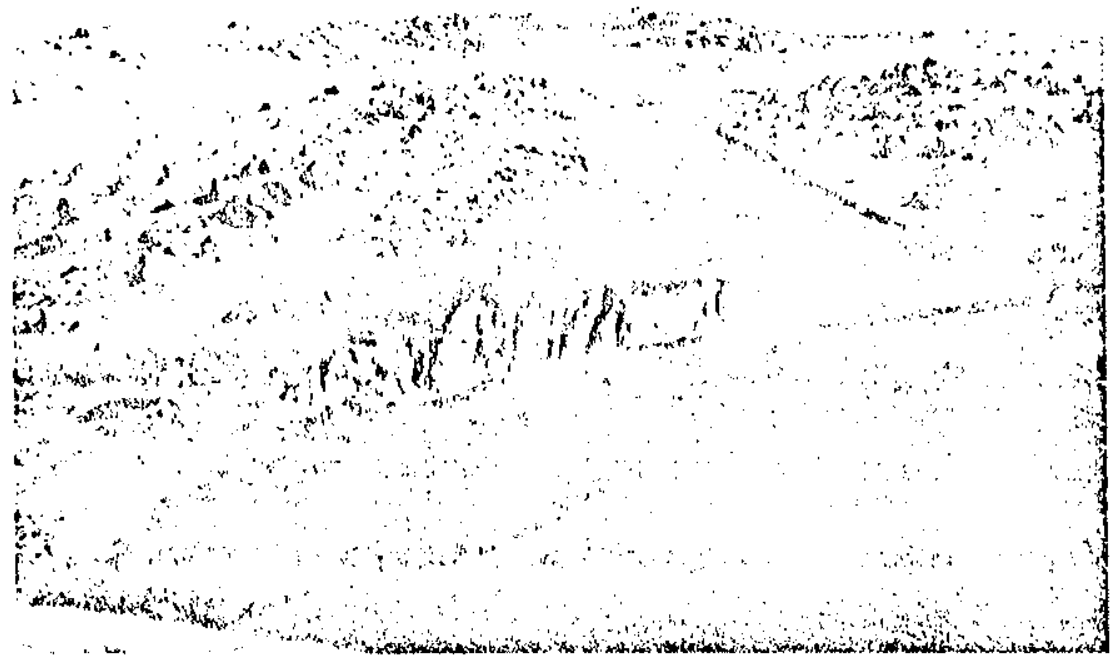

Fig 11 - Feição comum apresentada pelas áreas corn solos pod zolizados com cascalho; presença de grandes veşorocas e abundância en matacões.

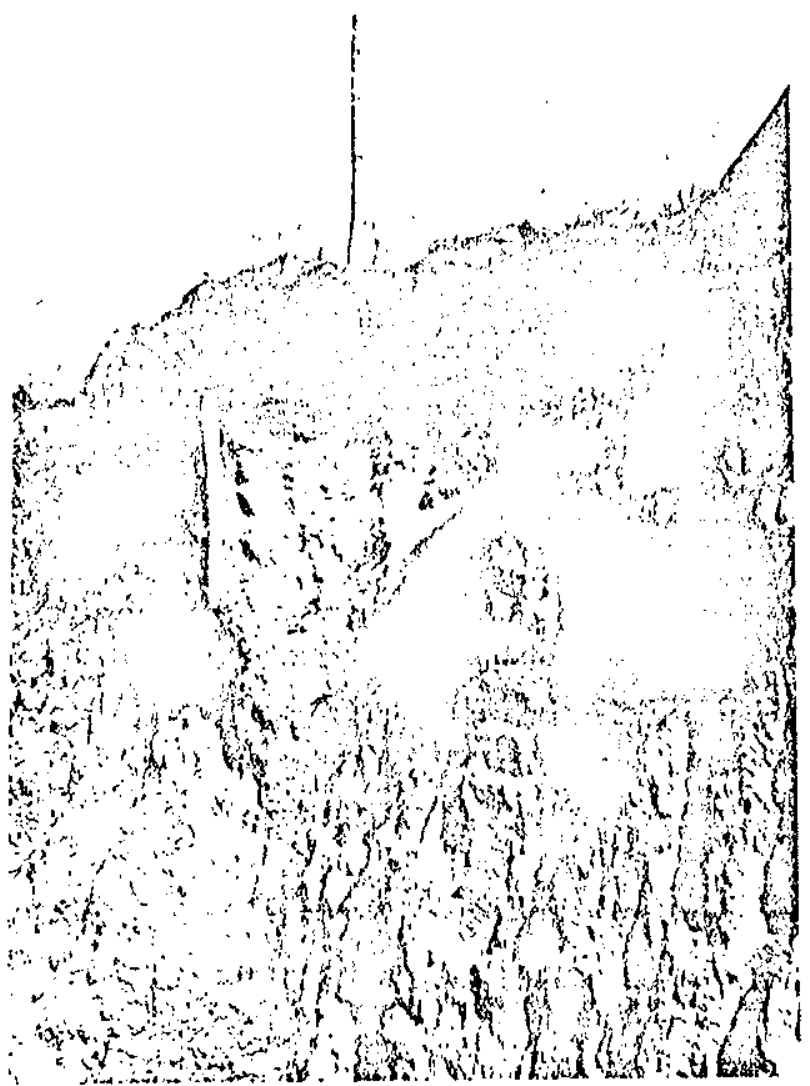

Fig. 12 - Perfil típico de solo podzolizado com cascalhos. Obser va-se a nítida separação dos horizontes. 
quentemente profundos, com horizontes mal definidos, apresentando passagem gradual ou difusa. O horizonte B, nos perfis mais argjlosc 3 podera ap:esentar uma estrutura incipiente, mas os agregado nãc säo em nenhum caso claramente desenvolvidos. A estrutura fundamentai é a subangular muito fina.

Pràticamente, não ocorrem no perfil os minerais primá rios mais fàcilmente intempexizáveis. O mineral do grupo das argilas predominante é a caulinita, que está comumente associa da a uma grande quantidade de ferro sob a forma de óxidos ou hidróxidos. Normalmente, associa-se ainda o hidróxido de alu mínio, que não é essencial, se bem que freqtente.

Em contraste com os granitos, a decomposição dọs diabásios é bastante rápicla com nossas condições climáticas, em virtude de ser urna rocha constituida de minerais bastante ins táveis nas condições-ambiente. Sòmente em locais onde a ero são é acelerada, podemos esperar o aparecido de blocos que mostram a sua śpica decomposição esferoidal.

O diabésio, a uma distância da ordem de alguns poucos decímetros, já perdeu pràticamente tôda a sua mineralogia ini cial.

Normalmonte, a rocha se exfolia em capas concêntricas, de espessuras variáveis: e primeira, nunca superior a $10 \mathrm{~mm}$, apresenta uma coloraç̃o verde-amarelada, pouco meis clara do que a rocha fresca original. Recotrindo esta camada, hé uma segunda mais extexna, exa geral mais e epếвz, da ordem de 20 a $40 \mathrm{~mm}$, constituída de um material avermelhado ou amarclo- 
-acastanhado, friável o pulvurolento. A composição mineralógica dêste material difore quase quo totalmente da composiç̃o da rocha original.

Em contato com êste material encontra-se o solo, ou antes, uma camada intermediária, que já apresenta tôdas as características do solo, mas contendo anda pequenos blocos de rocha parcialmente intemperizada (Fig. 13) e de coloração amarela. O solo descnvolvido sôbre diebásio é bastante espêsso, não sendo raras as profundidades superiores a 10 metros (Fig. 14). 


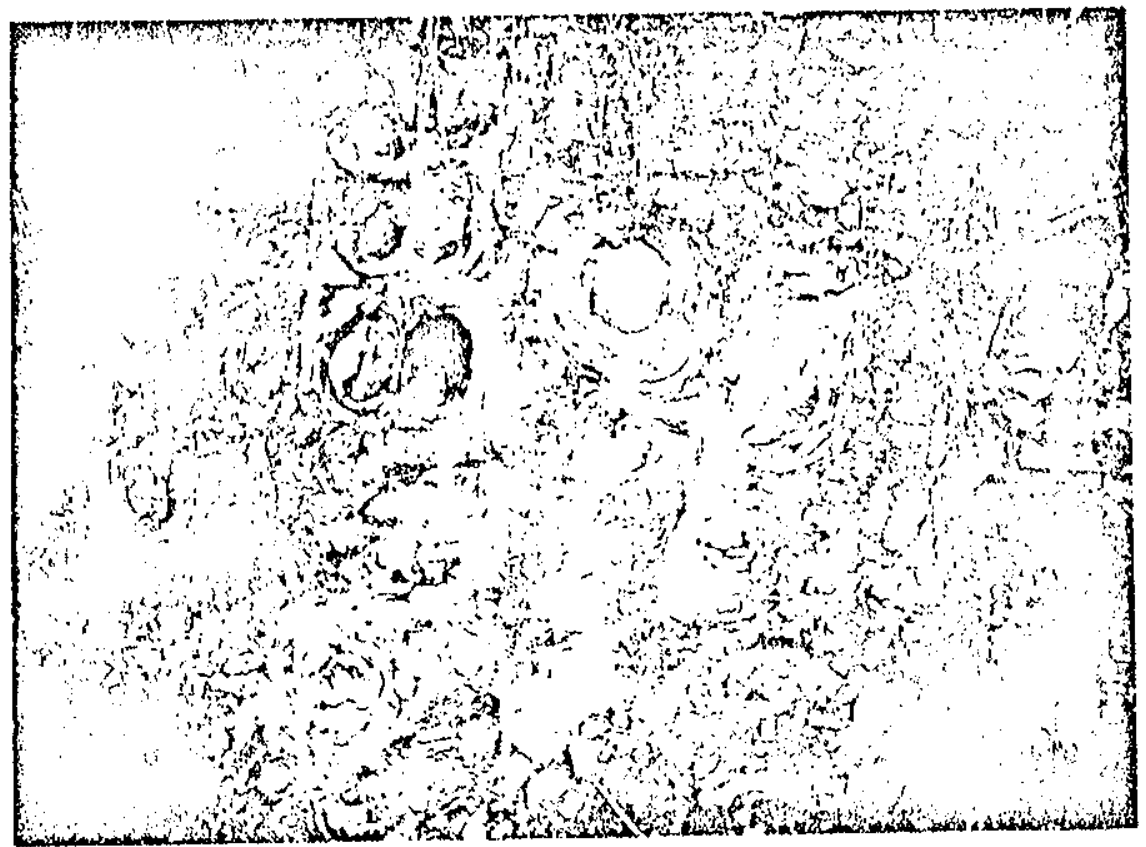

Fig. 13 - Decomposição esferoidal típica. Nota-se núcleos de diabásio totalmente frescos, envolvidos por ca madas concêntricas em diferentes estádios de alteração.

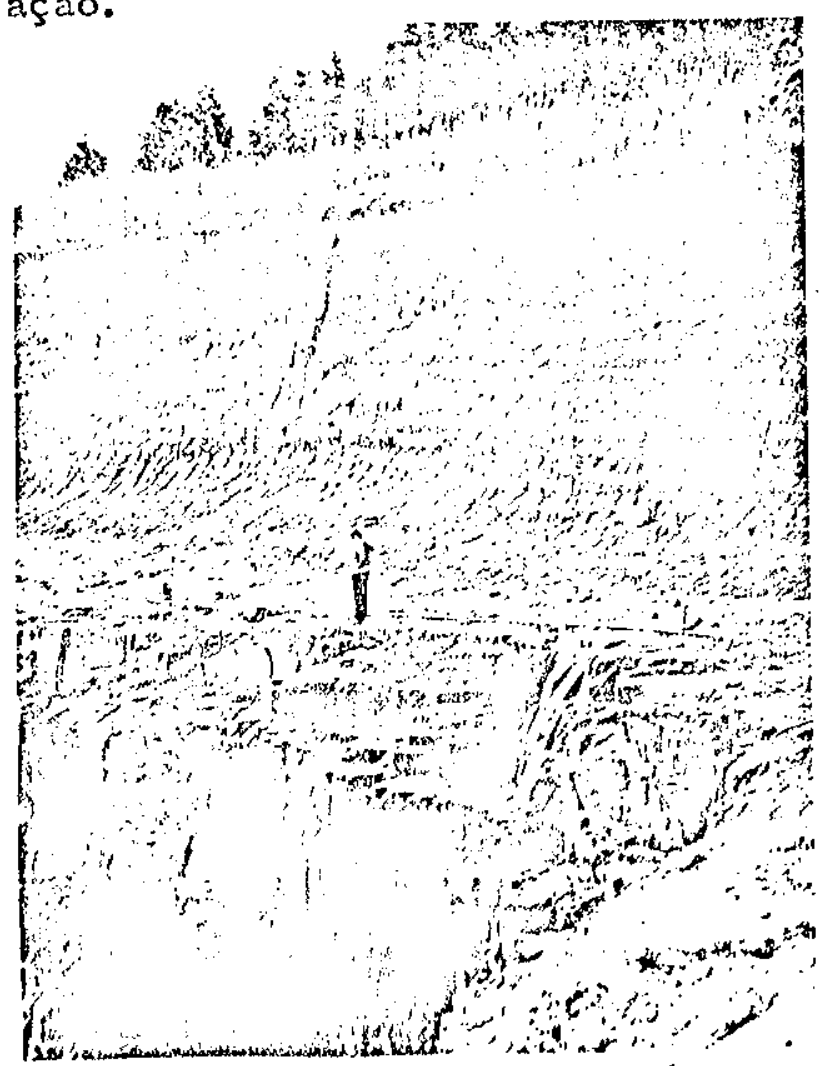

Fig. 14 - Pexfil típico de Terra Rosa legítima. Observa-be a pequena diferenciaçäo dos horizontes, bem como a grande espessura do solo. 


\section{CAPITULO III}

NAATERIAIS E NETODOS

1 - Materiais

Na figura 9 (mapa cie solcs da região) estän assinalados os locais de coleta dos perfio de alteração, em número de 11, seis dos quais serão descritos neste capítulo, pormenorizadamentc:aquêles analisados com mais detalhe.

As amostras foram coletadas preferencialmente em cor tes de estradas, já que nestes locais temos as melhores exposições de perfis completos de alteraç̃̃o que atingem a rocha fresca, na maior parte dos casos. INem todos os horizontes coletados fo$r$ am analisados do ponto de vista mineralógico. Os analisados re ceberam uma numexação crescente a partir das amostras coletadas de cima para baixo, isto é, do solo para á rocha mãe, antece dida por um prefixo que consta das duas primeiras letras do no me do município onde o perfil foi coletado.

Nas descrições dos perfis obedecemos, em geral, às normas e definições do Soil Survey Manual (U.S. Dept. Agricul., 1951). A determinação da côr foi feita em material úmido, por comparação com as côxes do Munsell Suil Color Chart (1954), sen do a designação da côr em português, de acôrdo com a tradução feita pela Sociedade Brasileira de Ciência do Solo (1956). 


\section{A - Descrifão dos perfis de alterac ão dos granitos}

a) exfil IT-1

Perfil situado no Nunicípio de Itu, no ponto mais alto do maciço granítico ao laclo dir estrada de rodagem que liga a cida de de Itu a Jundiaŕ. O perfil é raso, sendo a espessura do solo de, aproximadamente 1,00 metro.

O relêvo é bastante movimentado, ocupando o perfil uma posição topográfica de alto de morro. A drenagem, tanto a intex na quanto a externa é boa. Existe no local de coleta do porfil, erosão superficial do tipo laminar. A cobertura vegetal é de capirn-gorduxa.

Iorizontes

Símbolo

A. 1

$0-16 \mathrm{~cm}$ :
Descric ão

côr 10 YR 4/3 (bruno-escuro). Não apresenta estrutura, éum horizonte muito rico $\mathrm{m}$ casce 1ho. A passagem entre os hor i zontes é abrupta e ondulada.
$16-36 \mathrm{~cm}:$
A. $_{2}$
côx $10 \mathrm{YR} 4 / 4$ (bruno-averme
lhado). Não apresenta estrutu
ra, horizonte muito rico em
$I T-11$
cascalhos. Possui manchas $f i$
lamentosas $10 \mathrm{YR}$ \&/1. A pas-
sagem entre os horizontes é
clara e gradual ondulada. 
Horizontes

Símbolo

$\mathrm{B}_{21}$

${ }^{B_{22}}$

$\underline{1 T-12}$

$\mathrm{C}_{1}$

$I T-13 a$

$I T-13 b$
Profundidade

36 - $45 \mathrm{~cm}$ : Côr 7,5 YR 5/6 (bruno forte).

Não apresenta estrutura, hor

zonte muito rico em cascalhos.

A passagem entre os horizon -

tes é clara e gradual.

$45-74 \mathrm{~cm}:$

côr 5 YR 5/8 (vermelhomamare lado). Estrutura subangular fra

ca. O horizonte é rico em cas

calhos. Apresenta uma ligeira

cerosidade. A. passagem entre

os horizontes é gradual è irre

gular.

$74-120 \mathrm{~cm}$ : côr $5 \times \mathrm{R} 5 / 8$ (vermelh amare

lado). Nota-se grande quantida

de de material primário. Hori

zonte correspondente à rocha

alterada, saibro. Transição de

horizonte gradual e irregular.

$120-140 \mathrm{~cm}: \quad \cot 5$ YR $5 / E$ (vermelho-amare

lado). Nota-se grande quantida

de de material primário. Cor-

responde à rocha totalmente de

composta, Baibro.Tranoiģão de

horizonte gradual e irregular.

Apresenta muitas manchas de 
Horizontes

Símbolo

$D_{1}$

$1 T-14$

$\mathrm{D}_{2}$

$\underline{I T-15}$
Descrição

Profundidade

coloração mais clara.

$140-142 \mathrm{~cm}:$ rocha parcialmente alterada, for mando uma capa concêntrica fina que recobre parcialmente a to cha fresca. Apresenta uma côr um pouco mais clara gue o grani to róseo tipo Itr.

$142-? \mathrm{~cm}: \quad$ rocha pràticamente inalterada. Granito róseo tipo Itu.

b) Perfil IT -2

Perfil situado no kiunicípio de Itu, no mesmo maciço gra. nítico em que foi coletado o perfil IT - 1. Não atingimos a rocha fresca, que foi considerada a mesma do perfil anteriox. As camadas inferiores foram coletadas por meio de tradagens.

O relêvo da região é fortemente movimentado, sendo a po sição do perfil de fundo de vale. A drenagem é imperfeita, dando o rigem a um solo hidromórfico. A cobertura vegetal é de gramíneas. Horizontes Descrição

Sírnbolo

$A_{1}$
Profundidade

$0-11 \mathrm{~cm}$ : côr 10 YR 4/1 (cinzento escuro). Estrutura maciça. E um horizon$1 T-21$ te muito rico em cascalhos. O

contato entre os horizontes $\epsilon$ on 
Horizontes

Desc $x$ iç ão

Símbolo

Profundidade

dulado.

$\mathbf{G}_{1}$

11 - 38 crn: côr N7\% (cinzento claro). Horizonte arenoso, formado de

$I T-22$

grãos soltos, sem agregą̧̃̃o.

contato entro os horizontes é on dulado.

$\mathrm{G}_{2}$

$38-90 \mathrm{~cm}$

côr N7/, (cinzento claro).Fori: zonte compactado, arenoso, for mado por grãos soltos e serm 2 gregação. O contato entre os ho rizontes é onduledo.

$C_{1}$ $90-125 \mathrm{~cm}: \quad$ côr 2,5 YR 8/2 (bxanco). Apre senta grãos soltos e consistência não plástice e não pegajos:. O horizonte é bastante mosquas do.

$\mathrm{c}_{2}$ $125-? \mathrm{~cm}:$

côr 2,5 YR 8/2 (branco). Apre senta características semelhan tes $s$ is apresentadas pelo hori $\underline{I T}-23$ zonte anteriox, todavia aqui pre dominam os aspectos de roche. alterada. 
c) Perfil $\mathrm{MO}-1$

Perfil sltuado na serra das Cabras, na divisa dos Municípios de Itatiba e Morungaba, numa cota de 900 metros de altitude. A pronfudidade do solo ć de aproximadamente 1,50 metros. O relêvo é fortemente ondulado com declividade de $20 \%$, sendo a posição topográfica de alto de morro. A drenagem tanto a interna como a externa é moderada. No local de coleta do perfil e xiste grande quantidade de matacões, sendo forte a exosão superfi cial, causando ravinamento e voçoroca. A cobertura vegetal é de capim gordura.

Hoxizontes Descrição

Símbolo

$A_{1}$

Profunds desde

$0-6 \mathrm{~cm}$ :

cồ $10 \mathrm{YR} 4 / 3$ (bruno-scuro). A estrutura tende a granular, os grãos são soltos. O horizonte é rico em cascalhos. A passagem entre os horizontes é gradual on dulado.

$\mathrm{A}_{2}$

6 - $31 \mathrm{~cm}$ :

côr 7,5 YR $4 / 2$ (bruno-escuro). Estrutura subengular fina, horizonte rico em cascalhos. O con $\mathrm{NiO}-11$ tato entre os horizontes é nítido, abrupto e ondulado.

côx 5 YR $5 / 8$ a $6 / 8$ (vermelho-a marelado). Estrutura subangular média, horizonte rico em casca 
Horlzontes

Símbolo

${ }^{B} 21$

$\underline{\mathrm{NC}-12}$

$\mathrm{B}_{31}$

$C_{1}$

$B_{22}$

$$
\text { Descrif ão }
$$

Profundidade

lhos. O contato entre os horion tes é mátido, abxupto e ondulexb. 45 - $90 \mathrm{~cm}:$ côr $5 Y R 5 / 8$ (vormelho-amare lado). Estrutura subangular mé dia. Apresenta cerosidade. O horizonte é rico em cascalbos. O contato entre os horizontes é plano gradual, difuso. $90-145 \mathrm{~cm}:$ côr 5 YR $5 / 6$ (vermelho-amerc 1ado). Estrutura subangular mé dia, com cerosidade mais forte que o anterior. Exico em cascalhos. O contato de horizontes é semelhante ao anterior. $145-160 \mathrm{~cm}: \quad$ cô 5 YR $5 / 8$ (vermelho-amaxe lado). Estrutura subangular fina, horizonte rico em cascallos. C contato entre os horizontss é ondulado e gradual.

160 - $180 \mathrm{~cm}:$ côr 5 YR $5 / 6$ a $6 / 6$ (vermelhoamarelado), com manchas mais claras 2, 5 YR 5/8 (vermelho). $\underline{\mathrm{N}: \mathrm{O}-13}$
Estrutura granular grosoa. Ho rixonte rico em cascalhos, e 
Horizontes

Simbolo

$\mathrm{C}_{2}$

\begin{tabular}{l}
$\mathrm{MO}-14$ \\
$\mathrm{D}_{2} \quad \underline{\mathrm{NO}-15}$ \\
\hline
\end{tabular}

$\mathrm{D}_{1}$

$\mathrm{MiO}-15$
De bcrişa

Profundidade

contato ent:s os horizontes é

gradual ondiado.

180 - $300 \mathrm{~cm}:$ côx 5 YR $5 / 6$ a $6 / 6$ (vermelho -

amarelado), com manchas mais

claras $2,5 Y R 5 / 8$. Estrutura

granular grossa, mostrando to-

dos os aspectos semelhantes ao

anterior, entretanto mais pare-

cido com a rocha decomposta.

$300-400 \mathrm{~cm}: \quad$ cồ 2,5 YR 5/8 (vermelho). Ro-

cha totalmente decomposta, cla

ra, corn tôda a estrutura origi -

nal da rocha preservade.

$400-? \mathrm{~cm}:$ rocha fresca. Granito róseo, ti po Cabras.

B - Descricẽo dos perfis de alteraç̃o dos diabśsios

\section{a) Perfil CA - 1}

Perfil situado no Ninicipio de Campinas, numa regiño de altitude média de 700 metros de altura, O perfil é profundo, an contrando-se a rocha fresca a 8,00 metros de profundidede.

A topografia geral e no local do perfil é plana tendendo a ondulada, sendo a posição topográfica do perfil, de alto de collna. 
A drenagem interna e externa é boa, A cobertura vegetal É feita por cana de açúcar:

O perfil foi coletado na pedreira Chapadão. Não há no local erosão superficial.

Horizontes

De 3 c ri $\tilde{a}$ o

Símbolo

Profundidade

$A_{11}$

0 - 5 cm: $\quad$ côr 2,5 XR 3/6 (vermelho-e $\underline{9}$

curo). Apresenta estrutura

subangular entre fina e média.

Consistência plástica e pegajo

sa. Transição clara e plana.

$\mathrm{A}_{12}$

$5-12 \mathrm{~cm}$

côr 2,5 YR 3/6 (vermelho-es-

cuxo). Apresenta estrutura

subangular entre média e fina.

$\underline{C A-11}$

Consistência plástica e pegajo

ja. A transição dos horizontes

é claxa e plana.

$\mathrm{B}_{1}$

12 - $40 \mathrm{~cm}:$ côr $10 \mathrm{R} 3 / 4$ (vermelho acin zentado-escuro). A.presenta cs trutura subangulax média. Con sistência plástica e pegajosa.

A transição dos horizontes é gradual e plana.

$\mathrm{B}_{2} \quad 40-75 \mathrm{~cm}$ : côr $10 \mathrm{R} \mathrm{3/6}$ (vermelho-escuCA-12 xo). Apresenta estrutura guban gular média. Consiatência 
Horizontes

Símbolo

$\mathrm{B}_{3}$

$c_{1}$

$\mathrm{C}_{2}$
Descriça

\section{Profundidade}

plástica e pegajosa. A transição dos horizontes é gradual e plana.

$75-245 \mathrm{~cm}: \quad$ côr 10 R $3 / 6$ a $4 / 6$ (vermelhoescuro). Apresenta estrutura maciça que rompe em granu lar fina (pó de café). Consis tência plástica e pegajosa. Transição abrupta e ondulada. $245-382 \mathrm{~cm}: \quad$ côt $2,5 \mathrm{YR} 4 / 6$ a $4 / 8$ (verme 1ho). Apresenta estrutura granular fina, com ligeiro mos. queamento e restos de rocha $\underline{a}$ marela totalmente decomposta Transição de horizontes gra dual e ondulada. 382 - $504 \mathrm{~cm}:$ côx 2,5 YR 4/6 (vermelho) , contendo mais restos de roches que o horizonte anterior, com cồ 10 YR 6/8 (manchas escuras) e bastante mosquezdo. Transição dos horizontes, cla ra e ondulada. 
Hoxizontes

Símabolo

$\mathrm{C}_{3}$

Ches -14

$D_{1}$

CA-15

$\mathrm{D}_{2}$

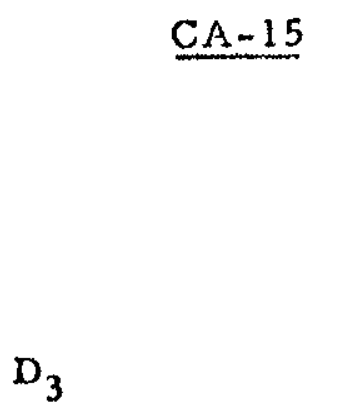

CA-16
Descrifão

Profundidade

$504.586 \mathrm{~cm}: \quad$ côr $10 \mathrm{R} 4 / 8$ (vermelho-cscu ro) com manchas $5 / 8 \odot 6 / 8$ e $10 Y R 6 / 8$ (amarelo-brunado). Pode pràticamente ser considexado rocha. Neste horizon te notamos a estrutura origi nal da rocha. Transição abrup ta e ondulada.

$586-806 \mathrm{~cm}: \quad$ côr $2,5 \times 5 / 6$ (vermelho) corn manchas escuras e veios 7,5 YR 5/8 (bruno escuro). Rocha totalmente decomposta com es trutura original preservada e seixos de diabásio com capas de alteração.

$806-809 \mathrm{~cm}:$ rocha parcialmente decompos te, formando uma camada que envolve a rocha fresca. Tem uma consistência batante friá vel e apresenta uma coloração avcrmelhada.

$809-810 \mathrm{~cm}: \quad$ rocha parcialmente decompos ta, no início de al texação. E 
Hoxizontes

Símbolo

Profundidade

Descrįão

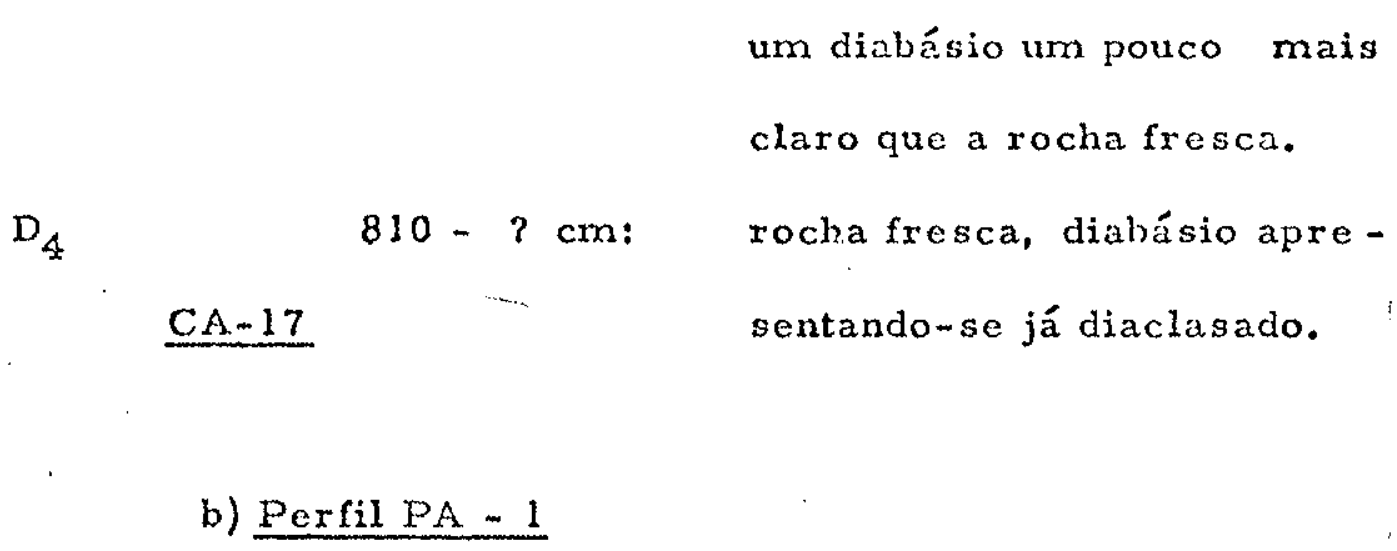

Perfil situado no Município de Paulínia, na margem es querda do rio Atibaia, em una região de al titude média de 550 metros. O perfil é profundo aparecendo a rocha fresca a 4,30 metros. A rocha é um diabásio de textura grossa, mais claro que os diabásios comuns.

A topografia geral e no local do perfil é levemente ondulada, sendo a situação topográfica do perfil de alto de colina. A drenagem, tanto interna como externa, é muito boa. A cober tura vegetal é de capim gordura.

O perfil foi coletado numa pedreira abandonada.

Horizontes

Descri̧̧ ão

Símbolo

Profundidade

A. 1

$0-13 \mathrm{~cm}$ :

$\operatorname{côr} 2,5$ YR $3 / 4$ a $3 / 6$ (verme 1ho-escuro). Apresenta estru tura granular fina bem desen volvida. Consistência plástica e pegajosa. Limite do hoxi 
Hoxizontes

Símbolo

$P A-11$

$\mathrm{A}_{3}$

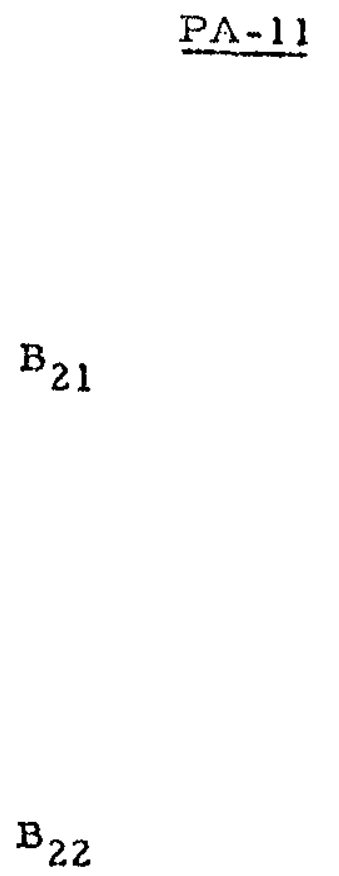

$P A-12$

C 1
Descrição

Profundidace

zonte abrupto e plano.

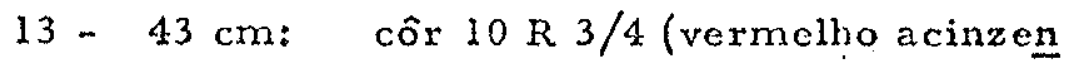
tado-escuro). Apresenta estru tura granular média a subangu lar fina. Consistência plástica e pegajosa. Limite entre os horizontes, abrupto e plano.

43 - $70 \mathrm{~cm}:$ côr $25 \mathrm{YR} 3 / 4$ (vermelho - escuro). - Estrutura granular grossa. Consistência plástica e pegajosa. O limite entre os hori zontes é claro e plano.

$70-105 \mathrm{~cm}:$ côr $10 \mathrm{R} \mathrm{3/4}$ (vermelho acinzen tado-escuro). Apresenta estrutu ra subangular grossa. E extre. mamente friável e o contato entre os horizontes é difuso e on dulados

105 - $180 \mathrm{~cm}: \quad$ côr $10 \mathrm{R} 2 / 4$ (vermelho acinzen tado-escuro). fipresenta estru tura subangular grossa. O horizonte tem um limite difuso e on dulado. 
Horizontes

Símbolo

$\mathrm{C}_{2}$

$P A-13$

$x^{2} \sin -14$

$\mathrm{D}_{2}$

$P A-15$

$\mathrm{D}_{3}$

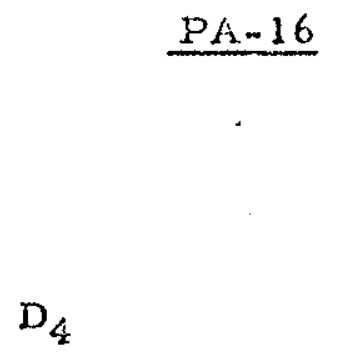

$\underline{P A-16}$

PA-17
Profundidade

$180-\$ 05 \mathrm{~cm}: \quad$ côr 2,5 YR 3/4 (vermalho os curo). Apresenta estrutura granular fina (pó de café). O limite entrc ow horizontes é difiso e ondulado. $405-430 \mathrm{~cm}: \quad$ côr $2,5 \mathrm{YR} 3 / 4$ (vermelho es curo). Rocha totalmente decom posta, porém preservancio a es trutura da rocha original. Totalmente manchado, com nódulos pretos e nódulos mais clexos. $430-431 \mathrm{~cm}: \quad$ rocha decomposta; crosta de al teração amarelada, tendo, no máximo, $1 \mathrm{~cm}$ de espes øura. $431-433 \mathrm{~cm}: \quad$ rocha parcialmente alterada. presenta uma coloração um pạ co mais clara que a rocha original, sendo ainda bastante corente. 433 - $? \mathrm{~cm}: \quad$ rocha fresca, diabásio.

c) Perfil $\triangle M_{1}-1$

Perfil situado no Wiunicípio de fumericana, em região 
de altitude média ao redor do 530 metros. Situa $\rightarrow$ se o perfil no fundo de um vale, o que impede uma perfeita drenagem. Somente foram coletados os materiais quc correspondem à rocha fresca, à parcialmente alterada e à totalmente decomposta. Não foi possível a coleta dos horizontes pedológicos, pelo fato de serem ésies trans portados, o que indica que tais horizontes se desenvolveram em condições diferentes daquelas encontradas no local. Hoxizontes Descriç̃

Símbolo

$C_{1}$

$A M_{2}-12$

$\mathrm{D}_{2}$ ANi-13
$A N_{i}-11$

Profundidade

$$
0-45 \mathrm{~cm} \text { : }
$$

rocha totalmente decomposta, amarelo-esverdeada, produzindo um material muito argiloso. No seu interior encontramos por vê zes restos de rocha parcialmente decomposta.

$D_{1} \quad 45-50 \mathrm{~cm}: \quad$ rocha parcialmente alterada, for mando crostas de exfoliação con cêntrica. Normalmente a espesgura é inferior a $5 \mathrm{~cm}$. rocha fresca, diabásio com pouca olivina.

2 - Métodos de investigaçós

Diversos métodos foram usados no presente trabalho, com - objetivo principal de determinax es várias fases o os vários mi - 
nerais formados pelo processo de intemperismo.

importante notar que raramente um único método é suficiente para a determinação dos minerai s, principalmente em se tratando de minerais neoformados, geralmente mal cristalizados e de tamanho bastante reduzido, quase sempre ocorren do em agregados.

Em vista do fato de todos os métodos possuirem limita §ó̃es neste tipo de estudo, procurou-se aplicar concomitantemen te várias técnicas expeximentais.

\section{A - Análise granulométrica}

Foram efetuados, no presente trabalho, dois tipos de análise granulométrica para cada amostra, um com a finalidade de estabelecer as classes texturais don diversos solos, e outro para a obtenção das frações para os estudos mineralógicos futu ros.

No primeiro caso, foi adotada a técnica utilizada na Seç̧ão de Agrogeologia do Instituto figronômico: trataram-Ee 10 gramas de terra fina, sêca ao ar com $50 \mathrm{ml}$ de $\mathrm{NaOH}$ a $0,1 \mathrm{~N}$. As frações determinadas foram: areja grosaa $(2-0,2 \mathrm{~mm})$, areia fina $(0,2-0,002 \mathrm{~mm})$, limo $(0,02-0,002 \mathrm{~mm})$ e argila (menor que $0,002 \mathrm{~mm}$ ).

Na obtenģão do matexial para análise minexalógica pax timos de 30 gramas de terra fina sêca ao ar, prèviamente sepa rada das frações acima de $2 \mathrm{~mm}$. Ante de ser efetuada a sepa ração, as amostras riç̇s em matéria orgânica foram tratadas 
com $\mathrm{H}_{2} \mathrm{O}_{2}$, que promove a retirada da matéria orgânica da mes ma. Em determinadas amostras foi realizada também a extração do ferro livre, pois a presença dêste em grande quantidade pode prejudicar a posterior identificação dos minerais existentes nos produtos de alter aç̃̃o, tanto nas frações grosseiras onde se tor na difícil a identificą̧ão microscópica, como nas frações mais fi nas (argila) onde o excesso de ferro livre prejudica a qualidade do difratograma. O método utilizado foi o preconizado por Asuillera e Jackson (1953), que empregaram o ditionito de sódio $\left(\mathrm{NaS}_{2} \mathrm{O}_{4}\right)$ como redutor, o bicarbonato de sódio como subotância tampão e o citrato de sódio como agente complexante para o fer ro ferroso e féxrico. O ferro assim extraído foi posteriormente dosado por métodos colorimétricos.

A fração areia grosia, acima de $0,2 \mathrm{~mm}$, é separada em primeiro lugax, por meio de peneira; e o material menor que $0,2 \mathrm{~mm}$,é transportado para cilindros de decantação. Lavagens sucessivas por meio de sifonagem permitiram a separação das fraçôes argila, limo e areia fina respectivamente. Para obter mos melhores resultados anal íticos, efetuamos em algumas amostras a separação em sub-frações das frações areia finc, $1 i$ mo e argila, com o auxílio de centrífuga, segundo o método pro posto por Jackson (1965).

Nas diversas aub-fraçöes da areia fina, assim como na sub-fração mais grosecira do limo, efetuamos a separação de mi nerai s pesados, por meio de bromofórmio (densidade $=2,87$ ). Nas frações grosseiras, eata separação fol feita segundo técnica 
descrita por Amaral (1965); entretanto, nas frações mais finas, a separaçã॰ por êste processo torna-se demasiadamente lenta. por is so utilizou-se a centrifugą̧̃o do material.

B - Análise mineralógica

As análises minexalógicas foram efetuadas em todos os perfis, sendo utilizadas principalmente técnicas de microscopia óptica e de difração de raios $X_{;}$e paxa complementar a identifi cação de diversos minerais secundários, empregaram-se métodos termo-diferenciais, de microscopia eletrônica e químicos, como auxiliares. Estas técnicas foram empregadas tanto nos pro dutos iniciais e finais envolvidos no processo intempérico, como também nas fases intermediárias da alteração mineral.

a) Microscopia óptica - Por meio do microscópio polari zador for am analisadas lâminas delgadas das rochas nos diferentes estádios de alterậ̃o; e lâminas dos resíduos leves e pesados das diversas sub-frações da frą̧̃o areia fina e da sub-fração mais grossa do limo, dos diferentes horizontes de alteração.

Em lupa binocular foram estudadas as frações areia gros sa e cascalho.

As lâminas dos resíduos fơram montadas com bálsamo do Canadá (resíduo leve) e com hyrax (resíduo pesado). O hyrax, devido ao seu alto índice de refração $(1,68)$ facilita a identificação dos minerais pesados. Em média contamos 500 grãos para cada fração. 
Na determinaçã॰ dos minerais utilizamos on métodos ópticos normais.

b) Difracãa de Raios - X - Juntamente com a microsco pia óptica, êste foi o método mais utilizado na presente pesqui6a.

Não só as frações limo e argila forami analisadas mine ralògicamente por intermédio da difrạ̧ão de raios $X$, mas também as rochas totais nos diversos estádios de alteração e o so 10. Em alguns casos, utilizamos a difração de raios $X$ no estu do da fração areia fina.

O material, antes de sex analisado, exa triturado com pletamente e em seguida colocado no suporte do difratógrafo No relco, sendo utilizado tubo de cobre no caso das amostras não possuirem teores elevados em ferro livre. Nestas amostras, as corridas ("scannings") foram $x$ ealizadas, usando-se $35 \mathrm{kV}$ e 20 MA. No caso do material possuir grande quantidade de ferro livre, o que acontece com as terras roxas, ou efetuamos a limpe za do ferro pelo método de Aguillera e Jackson(1953), retro-mencionado, ou então analisamos o material com o tubo de fer ro, sendo, neste caso, as corridas realizadas com $35 \mathrm{kV}$ e $10 \mathrm{~mA}$. As leituras dos difratogramas foram feitas em papelre gistrador, entre os ângulos de 2 e $60^{\circ}$, que possibilitaram a captą̧ão dos espaçamentos interplanares largos, até o espaça mento correspondente ao plano 060 do grupo das montmoriloni tas e caulinita; tal fato é fundamental para a difexencias̃ão dos 
minerais do grupo das argilas dioctaedrais do grupo das trioctae drais.

As raias medidas são, para cada mineral, as mais impor

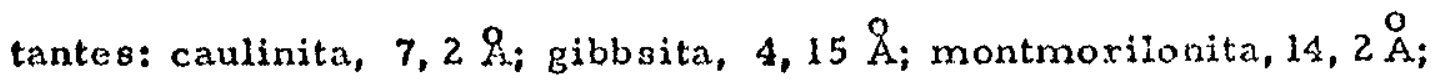
hematita, $2,69 \stackrel{\circ}{\AA}$ a $2,71 \stackrel{\circ}{\AA}$ e 2,51 a $2,52 \stackrel{\circ}{A}$ i vermiculita, 14,2 ; clorita, 14,2 $\AA_{i}$ plagioclásios $3,19 \stackrel{\circ}{A_{i}}$ feldspatos potás sicos quartzo, 3, $35 \stackrel{\circ}{\AA}$; micas $10,1 \stackrel{\circ}{\AA}$.

Como êsses espaçamentos correspondem ou podem cor responder a mais de um mineral, em diversos casos tivemos que recorrer ao emprêgo de técnicas auxiliares a fim de podermos efetuar a identificą̧̃o. Estas técnicas, apresentadas por Grim (1953), baseiam-se na contração ou expansão do espą̧amento ba sal, por ą̧̃̃o da temperatura ou de molécula polares.

A vermiculita e os minerais do grupo da montmorilonita e da clorita, apresentam raias características a $14 \stackrel{\circ}{A}$, sendo então difícil fazermos distinção entre êstes minerais, sem o emprê go de técnicas auxiliares. Os minerais do grupo da montmorilonita são fàcilmente identificados, pois sua primeixa raia basal pas sa de $14 \stackrel{\circ}{\AA}$ a $17 \AA$ quando o mineral é tratado com etileno glicol; e a $10 \AA$ após um a-uecimento a $500^{\circ} \mathrm{C}$. Os minerais do grupo da clorita se caracterizam fàcilmente, pois sua raia basal a la $\AA_{\text {Anão }}$ sofre deslocação nem com o aquecimento nem com o tratamento de etileno glicol. A vermiculita, ao contrário, já com um pequeno aquecimento apresenta mudaņ̧a de posição de sua raia basal.

c) Análise térmiç diferencial - Em um grande númexo de 
amostras, utilizamos como técnica complementat, a fim de confirmar certos reaultados duvidosos, a análise térmica diferencial O equipamento utilizado foi semelhante ao desenvolvido por Kapel e Sousa Santos (1763), de registro manual. Como comparador foi usada a nlunalize calcinada, que é uma substência tèxmicamente inerte até $1.100^{\circ} \mathrm{C}$.

Os fenômenos endotérmicos, como a desidratação e a quebra do retículo cristclino, provocam um abaixamento de temperatura em relação à substância inerte, enquanto que as rejōes exotérmicas, como a recristalizaşão e a formação de novas fases provocam um aumento de temperatura. Os termogramas foram desenhados colocando-se em abcissa as temperaturas, em orde nadas positivas as transformações exotérmicas e em ordenadas negativas as transformações endotérmicas.

Nas amostras represcntativas dos diversos estédios de alteração das rochas, foi analisado o material total, erquanto que nos solos, analisamos sòmente as frações argilosas.

d) Nicroscopia eletrônice - Este método foi utilizado pa ra a determiną̧ão do grau de cristalinidade dos minerais secundários formados no decorrer do processo intempérico, além dé permitir a detectaça de pequenas quantidades de halloysita em mistura com caulinita, o que seria impassível só por mátodos de difração de raios $X$, pois ambas possuem diagramas semelhan ter (Brindloy et al. 1963).

A preparação do material foi feita por dispersão em so- 
lução aquosa de hidróxido de amônia, segundo técnica descrita por Sousa Santos e Sousa Santos (1957).

\section{C - Análises quimicas}

a) Análises auímicas totais - Eotas análises foram efe tuadás em todos os pexfis coletados, tanto nas amostras das rochas em suas diversas fases de alteração, como nas amostras dos diferentes horizontes fedológicos.

Os óxidos dosados foram: $\mathrm{SiO}_{2}, \mathrm{Al}_{2} \mathrm{O}_{3}, \mathrm{Fe}_{2} \mathrm{O}_{3}, \mathrm{FeO}$, $\mathrm{TiO}_{2}, \mathrm{Na}_{2} \mathrm{O}, \mathrm{CaO}, \mathrm{MgO}, \mathrm{NnO}, \mathrm{P}_{2} \mathrm{O}_{5}, \mathrm{Fi}_{2} \mathrm{O}^{+}$e $\mathrm{H}_{2} \mathrm{O}^{-}$.

Em algumas amostras foram realizadas análises totais na fração argila, com a finalidade de obtermos dados complemen tares que auxiliaram não só na identificação dos minerais do gru po das argilas ou dos minerais sesquoxídicos mäs também na determinação mineralógice quantitativa.

O método analítico errpregado foi o método clássico da fusão alcalina para a dosagcm de silicatos. Tôdas as análises fo ram efetuadas na Seção de Agrogeologia do Instituto Agronômico do Estado, pelo técnico de laboratório Sx. Jordão Nepote.

b) Cálculos isovolumétricos - O estudo quantitativo da evolução dos constituintes de uma rocha no decorrer do intempe rismo, pode ser feito por diversos métodos geoquímicos. O mé todo tradicional de comparar ae análises químicas; o de Harri son (1933), de considerar o Ti um elemento constante em tôdas as 
fases do intemperismo; o de Molux (1738-1944), de consideror . ra efeito de comparação o Al como um elemento estável, todos êles apresentam falhas, pois devemos admitir que sempre no in temperismo há transformações com perda de pêso.

Para examinarmos o comportamento geoquímico dos elementos, utilizamos os célculos isovolumétricos desenvolvidos por Millot e Bonifas (1955) que se baseiam na conservação do vo lumo aparente nos difercntes estádios de intemperismo, onde a estrutura da rocha original ainda pode ser notada.

Para a elaboração das comparações, é necessário de teminar a densidade aparente do material que, por sua vez, de pende da determinação anterior do volume aparente.

Nos diferentes estádios de alteração das rochas a de terminação do volume aparente é simples, bastando tornar o material coerente e impermeável, o que pode ser conseguido por revestimento com parafina. A determinação do volume é fcita por meio de pesagern da amostra assim revestida, no ar e depois na água. O volume do revestimento de parafina deve ser corrigido.

No caso dos solos, coletamos no campo, por meio de um anel volumétrico de $50 \mathrm{cc}$ de capacidade, amostras prètice mente indeformadas. No laboratório, essas amostras são pesa das após secagem a $105^{\circ} \mathrm{C}$, determinando-se assim a densidade aparente. Após a sua obtunção calculamos a quantidedo de cada um dos óxidos dosados em 1 cc da amostra, para posterior camparação. 
SEGUNDA PAXTE

RESULTADOS E DISCUSSXO 
ESTUDO DO INTEMPERISNO DOS GRANITOS E A FORNIAÇAO DOS PERFIS DE ALTERAÇAO

O estudo do intemperismo do material granítico foi rea lizado em 5 perfis, quatro dos quais desenvolvidos em condiçōes de drenagem boa ou moderada, e o Giinto sob condisöes de hidro morfismo. Devido à similaxidade de resultados nos perfis desen volvidos sob as mesmas condições, foram selecionados apenas três, considerados representativos para tôda a área e cujos re sultados passaremos a expor.

$$
1-\operatorname{Perfil}-\mathrm{I} T-1
$$

\section{A - Análise granulométrica}

A observação da tabela 3 e da figura 15, mostra que a passagem do material original para o solo manifesta-se por um aumento gradual das frações grosseiras de aproximadamente $50 \%$ na rocha totalmente decomposta, para mais de $70 \%$ no horizonte pedológico A.

A fração cascal ho é sempre bem desenvolvida ao longo de todo o perfil, o que aliás é uma característica dos solos desenvolvidos sôbre os granitos da área.

A fração axgila ocorre cm pequena quantidade nos horizontes inferiores correspondentes ao saibro, porém aumenta xàpidamente com a evolução do perfil, sofrendo forte concentra ção no horizonte $\mathrm{B}_{22}$, por razões puramente pedogenéticas. 
TABELA 3

Composição granulométrica do perfil IT-1

TERRA FINA SECA AOAR

\begin{tabular}{|c|c|c|c|c|c|c|c|c|}
\hline Horizontes & $\begin{array}{r}\text { Profu } \\
\text { em }\end{array}$ & $\begin{array}{l}\text { ndidade } \\
\mathrm{cm}\end{array}$ & $\begin{array}{c}\text { Cascallo } \\
\% \\
=2 \mathrm{~mm}\end{array}$ & $\begin{array}{c}\text { fireia } \\
\text { Grossa } \\
\% \\
2-6,2\end{array}$ & $\begin{array}{c}\text { Areia } \\
\text { Fina } \\
\% \\
\%, 2,0 \%\end{array}$ & $\begin{array}{l}\text { Limo } \\
\% \\
5_{1}, 2-0, \cdots \infty\end{array}$ & $\begin{array}{l}\text { firgila } \\
\text { \% }\end{array}$ & $\begin{array}{l}\text { Classe } \\
\text { textural } \\
\text { da TFS }\end{array}$ \\
\hline$A_{1}$ & 0 & -16 & 60,1 & 15,2 & 10,6 & 6,2 & 8,0 & $\begin{array}{c}\text { Areno } \\
\text { barrentc }\end{array}$ \\
\hline$f_{2}$ & 16 & -36 & 70,1 & $\exists, 0$ & 9,1 & 4,9 & 7,0 & $\begin{array}{l}\text { Areno } \\
\text { barrents }\end{array}$ \\
\hline$B_{11}$ & 36 & -45 & 66,5 & 7,7 & 9,5 & 5,0 & 11,3 & Barrer \\
\hline$B_{22}$ & 45 & -72 & 51,6 & 6,3 & 12,4 & 6,7 & 23,0 & Argilo \\
\hline C & 74 & -140 & 34,5 & 12,7 & 27,3 & 10,0 & 15,5 & \\
\hline
\end{tabular}

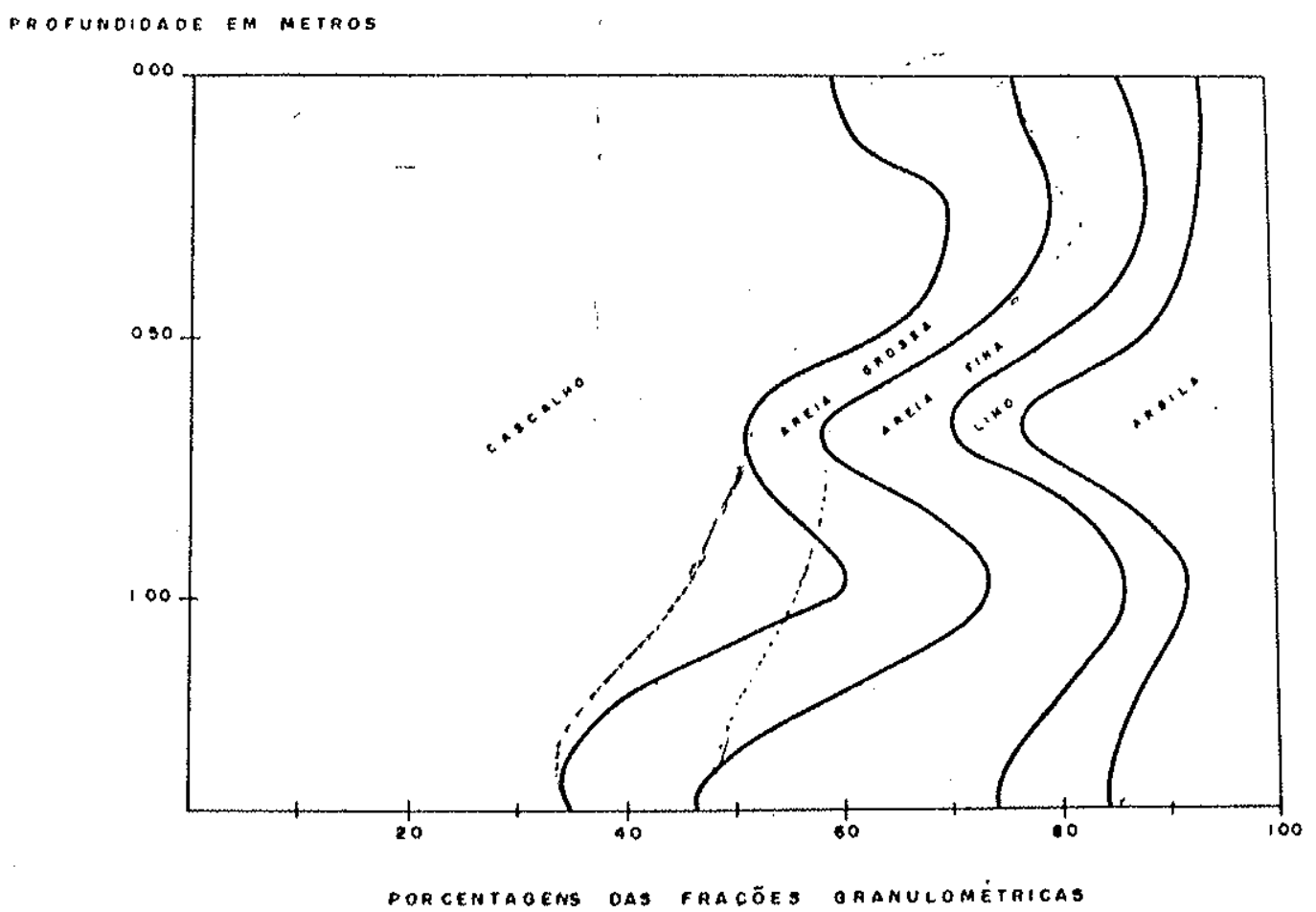

Fig. 15 - Distribuição das frações granulométricas ao longo do perfil IT-1. 


\section{B - fanálise mincralógica do perfil}

IT -15

Rocha completamente fresca. Granito tóseo de textura grossa. Sua composição mineralógica é simples, e revela tra tar-se de um alasquito, por sua extrema pobreza em minerais máficos e alto teor em feldspato alcalino.

O feldspato potássico é o principal constituinte, perfazendo $51 \%$ do volume total da rocha; forma cristais gxandes. apresentando-se geralmente pertítico, com dimensões variando de 4 a $7 \mathrm{~mm}$, podendo mais raramente, apresentar tamanhos su periores a $1 \mathrm{~cm}$. Em muitos cristais notamos o gradeamento de microclínio. O quartzo vem a seguix com $31 \%$; seus cristais são grandes, porém menores que os de feldspato potássico. São comuns as bolhas de gás, exibindo quase sempre extinção ondulan te. Os plagioclásios constituem cêrca de $14 \%$ do volume da rocha, aparecendo em cristais idiomorfos ou hipidiomorfos, que atingem dimenoões de aproximadamente $3 \mathrm{~mm}$, com composi ção por volta de $A_{2} b_{90} A_{10}$ ou $A_{15} b_{8 n_{15}}$, portanto, altamente só dicos. Frequentemente êstes cristais são zonados, apresentando nestes casos composições mais cálcicas. Em quase todos os cristais de plagioclásio notamos um incipiente processo de saussuritização, havendo a formação de sericita. Ao que parece, êste processo estaria ligàdo a fenômenos hidrotermais e não intempéricos. A biotita é escasøa, constituindo sồmente 
1, 5\% do volume da rocha. Apresenta coloração marron na maio ria dos cristai s. Foi constatada clorita associada à biotita. Final mente os restantes $2,5 \%$ do volume da rocha são constituŕdos pe los minerais acessórios. Os mais importantes quantitativamente são: opacos (ilmenita e magnetita); apatita, que geralmente se as socia à biotita; titanita e zirconita.

$$
\mathbf{I T}-14
$$

Rocha parcialmente alterada, num estádio muito inci piente de alteração. Forma uma crosta, de no máximo $2 \mathrm{~cm}$ de es pessura, que recobre a rocha fresca. Este nível foi estudado minexalògicamente por intermédio de uma lâmina delgada, cortada perpendicularmente ao contato rocha fresca - rocha alterada.

O quartzo não evidencia nenhum sinal da ação do intempexismo, continuando límpido tal como na amostra anteriox.

A biotita perde parte de seu ferro, que vai tingir par . cialmente o material estudado. Entretanto, microscòpicamente , continua apresentando tôdas as características ópticas que the são peculiares.

Os plagioclásios e os feldspatos potássicos apresentam ocasi onalmente manchas escuras (aos nícois cruzados), que se desenvolvem a partir das fissuras e clivagens dos cristais. Es tao manchas, totalmente isótropas, têm sido interpretadas por di versos autores como gels amorfos, e representariam o primeiro estádio na transformação dos feldspatos por ação do intemperis - 
mo. Entretanto, no nosso caso, a formação dêste material sòmun .. te ocorre em alguns cristais, não sendo o processo principal de alteração.

Tanto os plagioclásios como os feldspatos potássicos a presentam, já neste estádio, uma incipiente alteração para gibbsi ta (Fig. 16), porém em quantidede extmemament a biai:a pura ser detectada pelos raios X (Fig. 17).

IT -13

Este horizonte representa o saibro, isto é, rocha total mente desagregada. Para efeito do estudo, dividimos êste nívél em dois diferentes sub-níveis: um próximo à rocha alterada parcialmente (IT - I3b) e outro, mais acima, próximo ao horizoiate de transição entre o saibio e o solo (IT - 13a).

$1 T-13 b$

O quartzo sofrc um enriquecimento residual, em virtude de sua grande resistência ao intomperismo, sendo que alguns grãos mostram um ligeiro arredondamento. Sua concentração é maiox nas fraçôs mais grosseiras, podendo atingir $60 \%$ na fra ção areia grossa e cêrca de 70\% na frą̃ão cascalho. Este teor cai bruscamente para menos de $10 \%$ nas frações areia fina e limo não sendo detectado na frą̧̃ äo argila.

Os feldspatos apresentam comportamento distinto. $O$ plagioclásio sofxe um decréscimo acentuado, ficando restrito às frações mais grosscixas. Alguns grãos brancos, sem brilho $\in \mathfrak{g}$ ralmente cavernosos representam os últimos resquícios dos cris- 


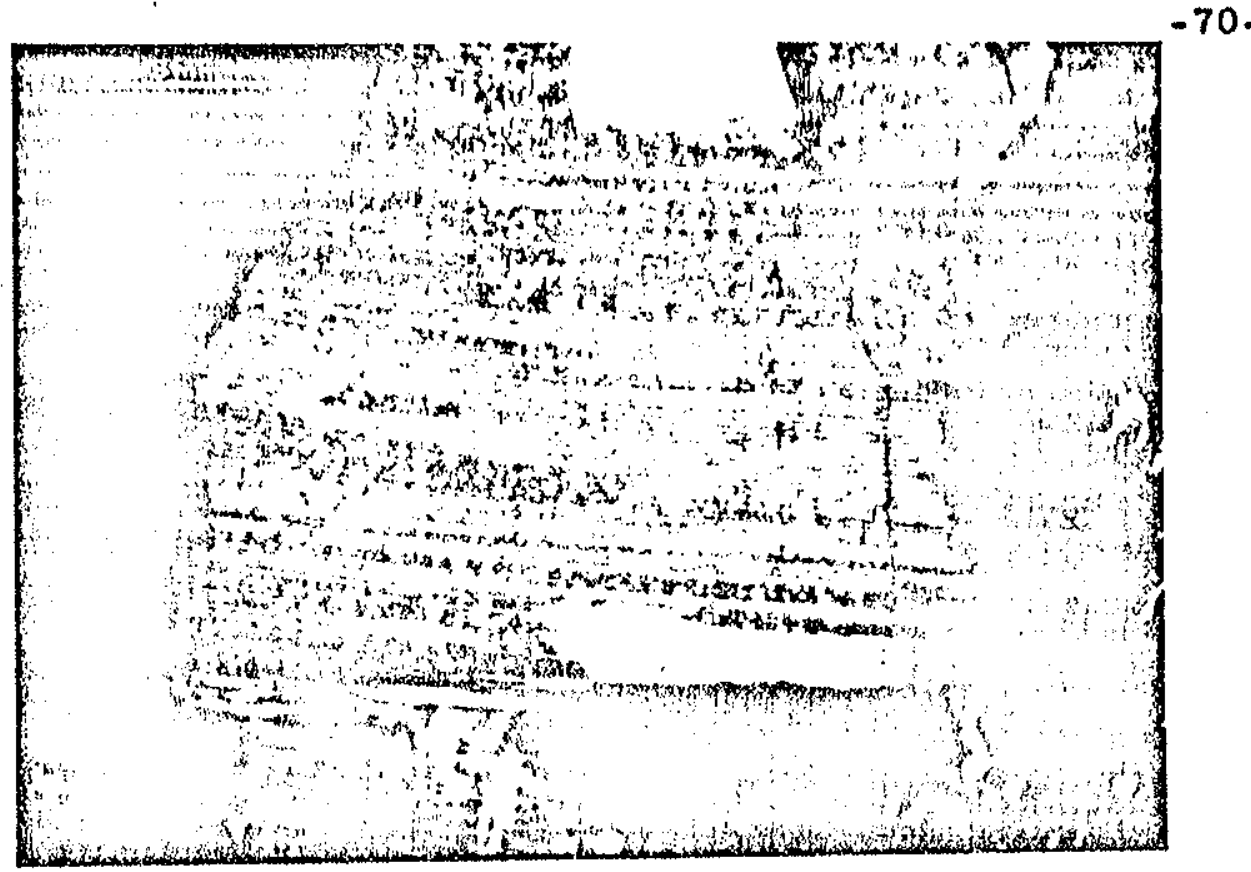

Fig. 16 - Alteração do feldspato em gibbsita nas fases iniciais de alteração do granito

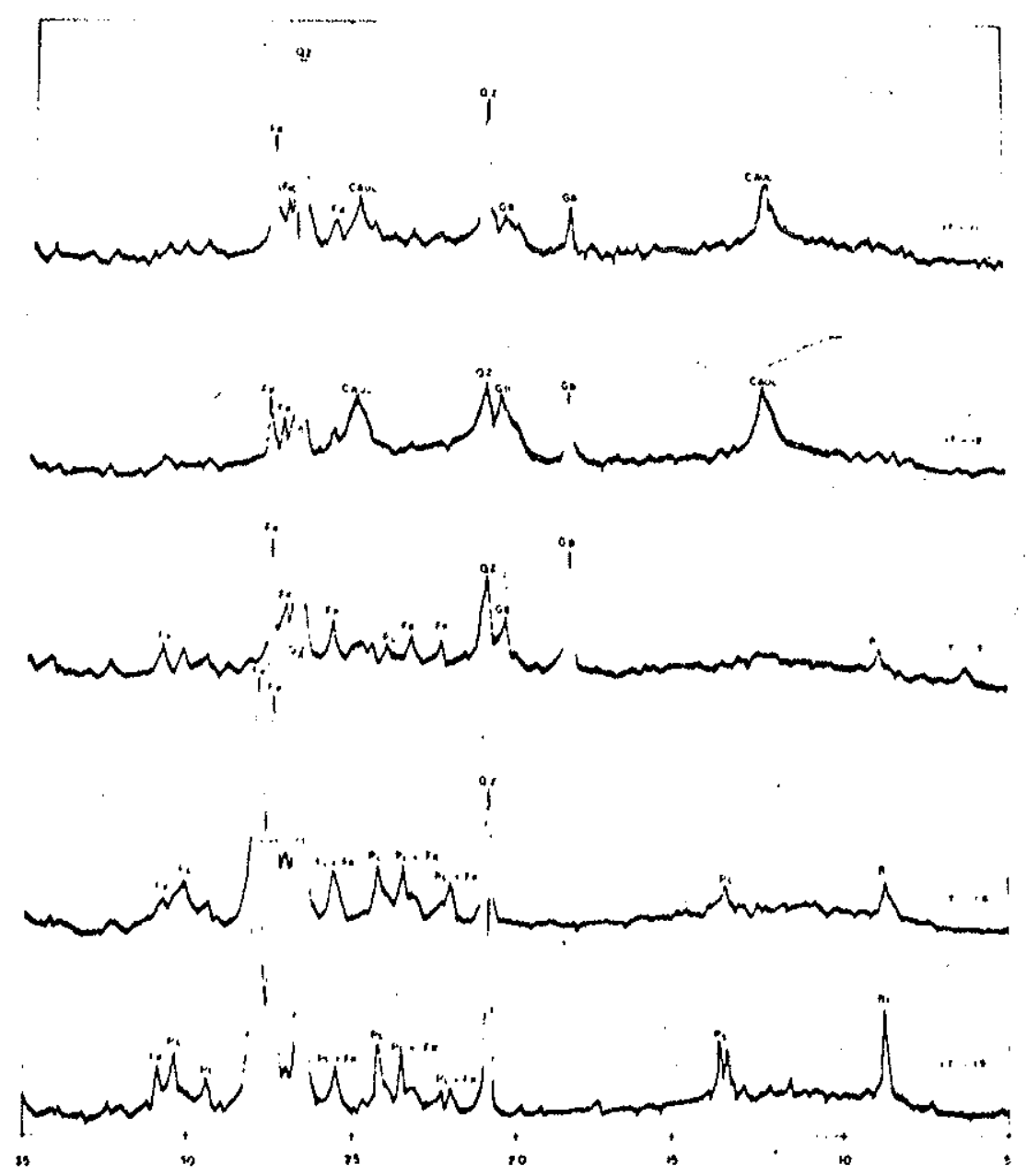

Fig. 17 - Difratogramas dos diferentes níveis de alteração do perfil IT-1. Qz(quartzo), FK (feldspato potássico), Pl(plagioclásio), Bi (biotita), GB(gibbsita) e CAUL(caulinita). 
tais de plagioclásio. O feldspato potássico, mals resistente à acio do intemperismo, apenas torna-se mais claro, não mantendo sua típica coloração e perdendo também seu brilho.

Examinando-se detidamente diversos grãos que aprcęp tavam aspectos externos de feldspatos, verificou-se que suas es truturas não eram mais de tectosilicatos, mas sim de gibbsita. que é o primeiro mineral de alterạ̧ão a aparecer. A gibbsita occx re microcristalina, substituindo os cristais de feldspato, preser vancio a forma externa dêstes; em alguns casos mesrno a clivagem original dos cristais é mantida.

Neste nível a gibbsita concentra-se nas frações areiafi na e limo, e aparece em quantidade menor na fração argila, que seria a fxação onde deveríamos encontrax maior concentração (Figs. 18, 19 e 20).

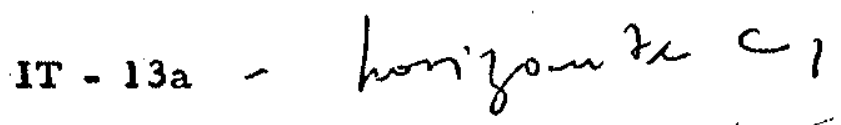

O comportamento mineralógico dêste horizonté é bastan te similar ao anterior, havendo apenas diferenças quantitativas na composição mineralógica.

A biotita, que desde o início da alteração vinha diminu indo gradativamente de porcentagem, pràticamente desaparece neste estádio, transformando-se em vermiculita.

\section{$1 x-12$}

Neste estádio de alteração, já se nota a interação de pro cessos geológicos e pedológicos: trata-se de um horizonte edafoló gico que, pelas características apresentadas, pode ser classifica do como um horizonte $\mathrm{B}_{22}$. 


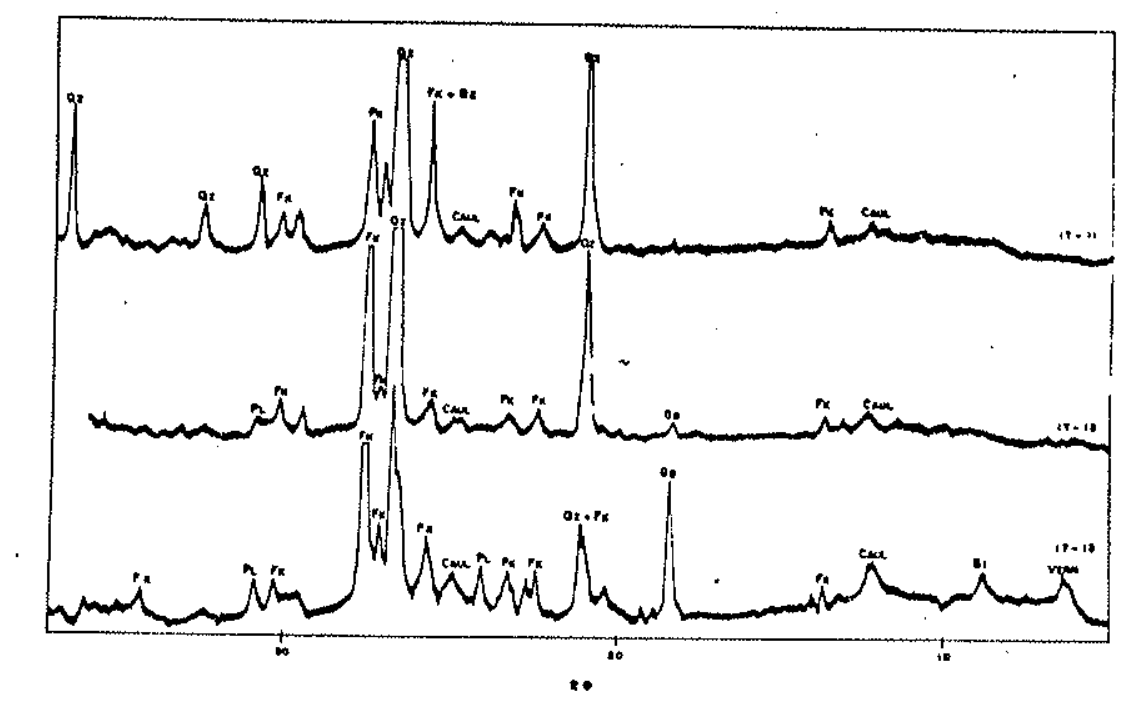

Fig. 18 - Difratogramas da fração areia fina $(0,2-0,02 \mathrm{~mm})$ do perfil de alteração IT-1

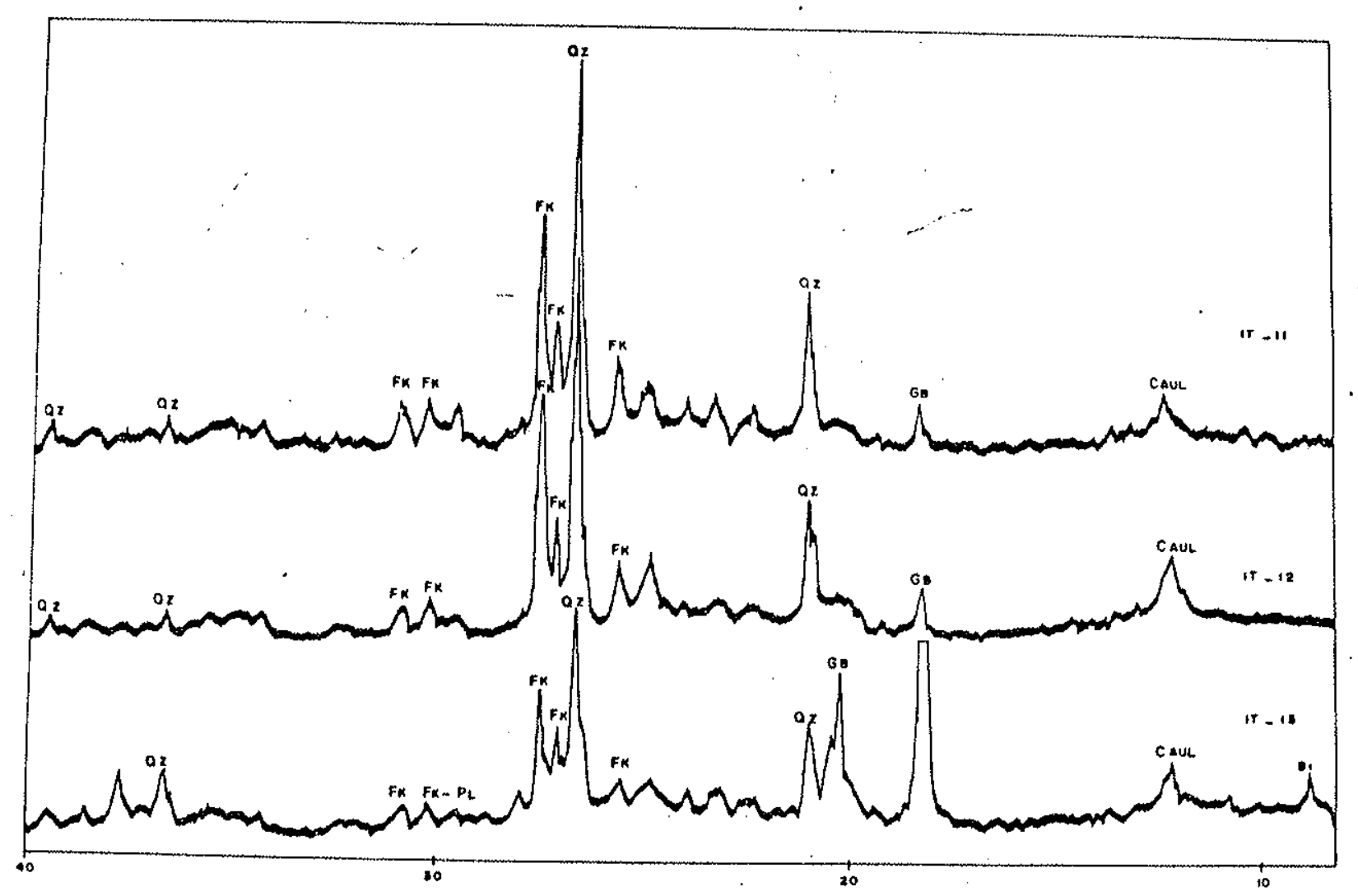

Fig. 19 - Difratogramas da fração limo $(0,02,0,002 . \mathrm{mm})$ do perfil de
alteraça IT-1. 
O fato mais importante neste horizonte é notar o desapa recimento dos plagioclásios, totalmente transformadoa $\mathrm{em}$ gibbsi ta. O feldspato potássico aparece ainda, mas em menor quantidade, e concentra-se nas fraçōes intermediárias, areia fina e limo, pois a ação do intemperismo causa a quebra de seus cristais e conseqtentemente, seu desaparecimento das frações mais grossẹ ras.

O quartzo é ainda o mineral predominante do horizonte, constituindo mais de $90 \%$ da fração cascalho e cêrca de $70 \%$ na fração areia grossa.

A gibbsita, que no horizonte anterior era o principal mineral de neoformação, decresce em quantidade, cedendo seu $\underline{\mathrm{u}}$ gar para a caulinita. Tal fato é sugestivo para explicar uma pos sível transformação da gibbsita em caulinita por moio de ressili catizaşão.

Neste horizonte aparece um outro mineral de neofor mação: halloysita, que pelo fato de possuir grande semelhança es trutural com a caulinita, e ainda por aparecer em pequenos quan tidades só pode ser detectada corn o auxílio de microscopia ele trônica (Fig. 21).

A vermiculita, que no estádio anterior atingiu seu teor máximo, sofre neste estádio um ligeiro decréscimo. Tanto nes te nível como no anterior, associada ì vermiculita, encontramos subordinadamonte clorita, que pode ter-se formado no próprio so lo por alterą̧a intempéxica da biotita ou ter vindo do granito . juntamente com a biotita, possuindo, portanto uma ofigem hidrom. termal.

IT -11

Representa o estádio final do intempexismo no perfil de 


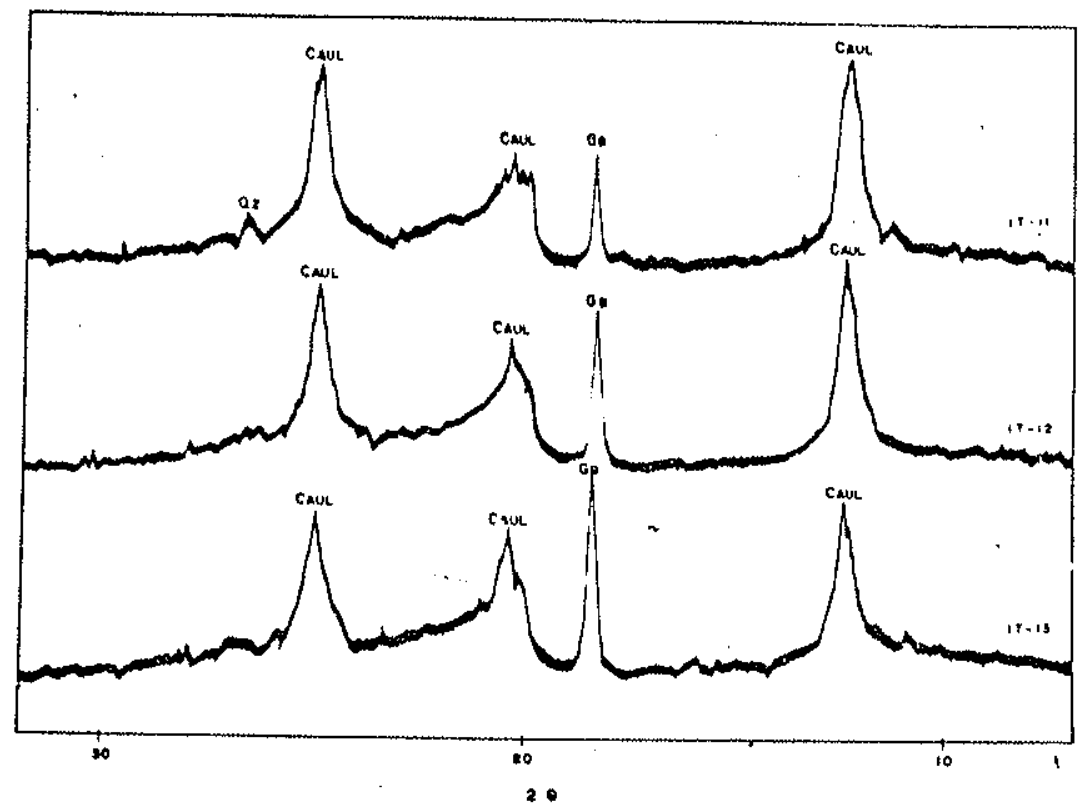

Fig. 20 - Difratogramas da fração argila (menor que $0,002 \mathrm{~mm}$ ) dos níveis de alteração do perfil IT -1 .

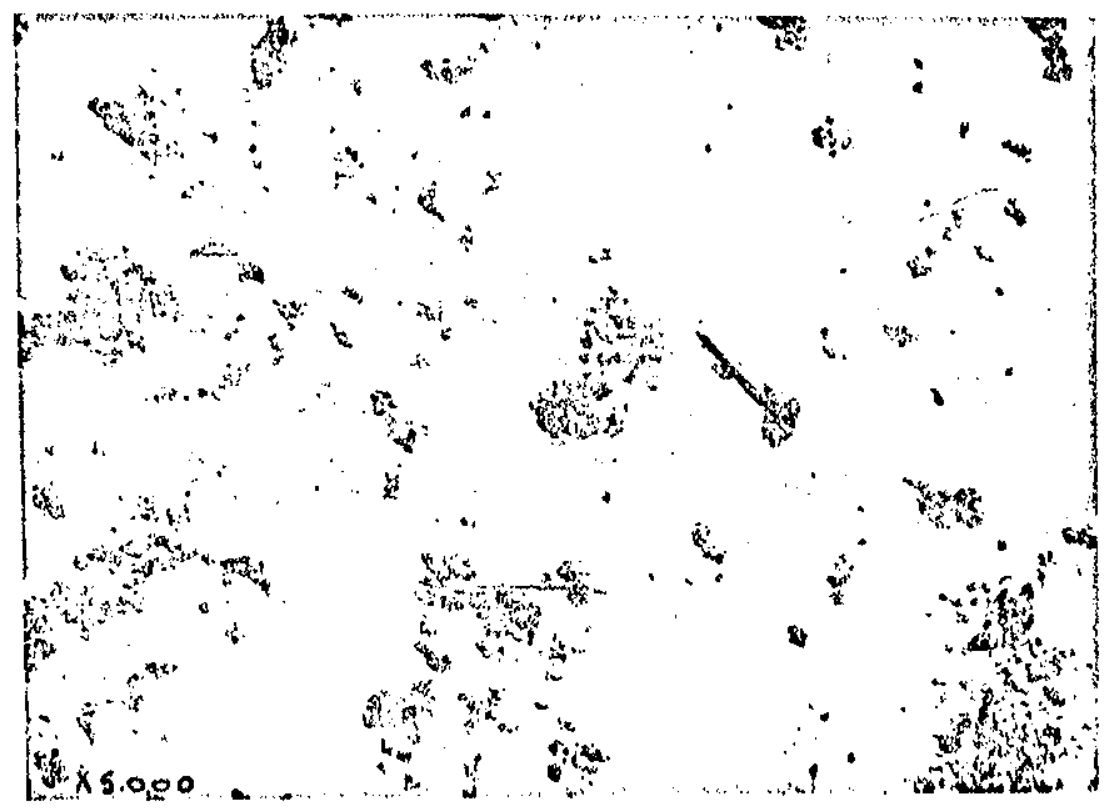

Fig. 21 - Nicroscopia eletrônica da fração argila da amostra IT-12; observando-se: a)cris tais de caulinita de dimensões muito te duziclas $e$ b) pequena quantidade de tubos finos de halloysita. 
alteração. E o horizonte mais superficial, sendo bastante afetado por material estranho que contamina êste nível e torna difícil o contröle da evolução do intemperismo.

o quartzo é o mincral principal, contribuindo com mais de $60 \%$ do volume total do solo, enquanto que há um apreciável decréscimo do feldspato potósisico em relação ao horizonte anterior.

A caulinita mantém-se pràticamente constante, mostran do ser o mineral de neoformação mais resistente apezar de sofrer, neste horizonte, certa diminui ser constatado pelo difratograma de raios $X$. A gibbsita e a vermiculita sofrem uma diminuição progressiva em seus teores.

A tabela 4 e a figura 22 representam os dados mineralógicos da evoluçãc do perfil IT -1 .

\section{C - Análises Químicas}

As análises químicas e os cálculos irovolumétricos dos diferentes horizontes do perfil IT - 1 estão representados na tabela 5 .

$$
2-\operatorname{Pertil} I T-2
$$

A - Snálise granulométrica

A análise da tabela 6 e da figura 23 evidencia que a passagem da rocha mãe para o solo se verifica com acentuado decrés cimo das frações grosseiras durante todo o perfil, aumentando sòmente junto ̀̀ superfície.

Como no perfil anterior êste é caracterizado pelapresenfa de cascalho em todos os horizontes, se bem que em quantidades inferiores. O horizonte correspondentc ao saibro é o que apresenta maiox porcentagem de fraçöes zrosseiras, que constituem mais de 
TABELA 4

Composição mineralógica dos diferentes níveis de alteração do perfil IT-1 cm \% (volume)

$$
\text { IT-15 IT-14 IT-13b IT-13a IT-12 IT+11 }
$$

$\begin{array}{lcccccc}\text { Guartzo } & 31 & 31 & 33 & 38 & 56 & 67 \\ \text { Feldspato } 3 & 51 & 50 & 36 & 25 & 20 & 13 \\ \text { Plagioclásio } & 14 & 12 & 7 & 5 & 2 & \mathrm{tr} \\ \text { Biotita } & 1,5 & 2 & 1 & 1 & \mathrm{tr} & \text { tri- } \\ \text { Caulinita } & - & - & 1 & 3 & 11 & 9 \\ \text { Gibbsita } & - & 3 & 12 & 19 & 6 & 3 \\ \text { Halloysita } & - & -5 & - & \mathrm{tr} & \mathrm{tr} & \mathrm{tr} \\ \text { Vermiculita } & - & - & 5 & 7 & 2 & 2 \\ \text { Acessórios } & 2,5 & 2 & 3 & 2 & 3 & 6\end{array}$

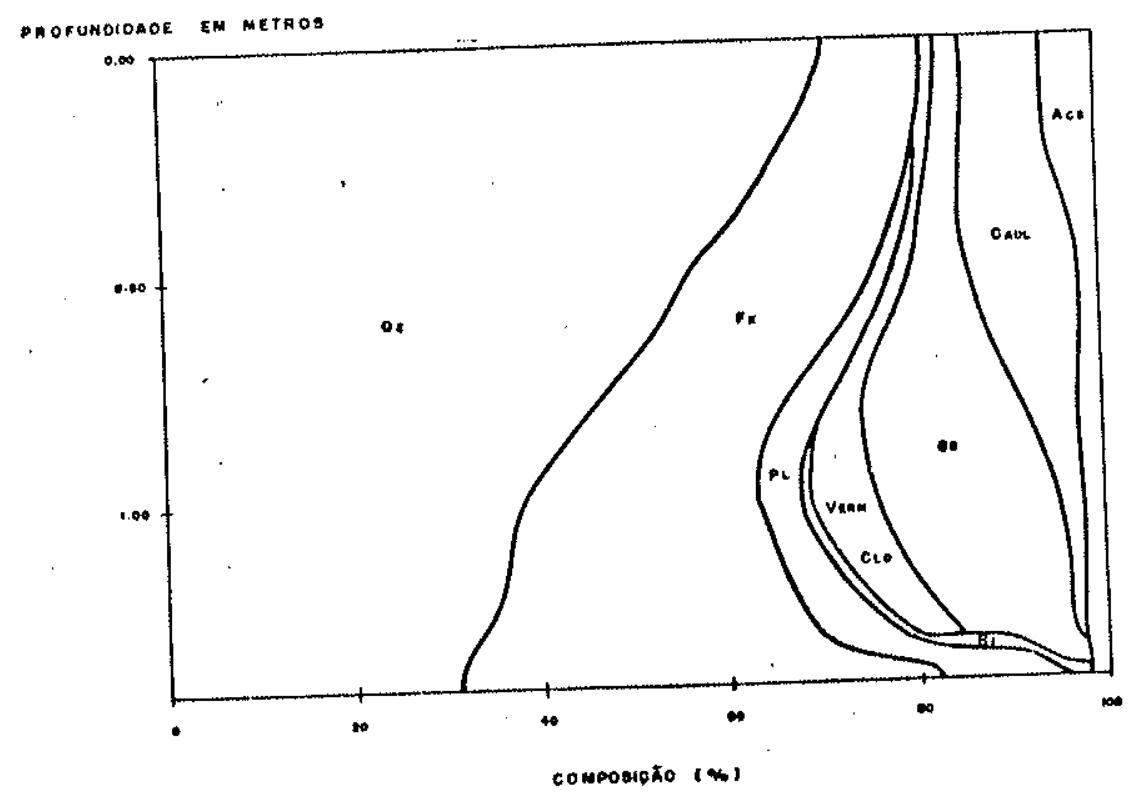

Fig. 22 - Esquema mineralógico do perfill IT-1 
TABELA 5

Análises químicas totais do perfil $\mathrm{IT}-1$ (porcentagem pêso) e porcentageno a volume constente calculadas a partir das análises químicas

\begin{tabular}{|c|c|c|c|c|c|c|}
\hline $\mathrm{SiO}_{2}$ & $\begin{array}{l}1 T-15 \\
71,40\end{array}$ & $\begin{array}{l}1 \mathrm{~T}-14 \\
69,80\end{array}$ & $\begin{array}{c}1 T-13 b \\
65,5 J\end{array}$ & $\begin{array}{c}1 T-13 a \\
60,00\end{array}$ & $\begin{array}{c}1 T-12 \\
46,30\end{array}$ & $\begin{array}{l}I T-11 \\
61,50\end{array}$ \\
\hline $\mathrm{Al}_{2} \mathrm{O}_{3}$ & 14.50 & 15,00 & 20,20 & 26,80 & 30,20 & 17,40 \\
\hline $\mathrm{Fe}_{2} \mathrm{O}_{3}$ & 1,27 & 2,20 & 3,20 & $4 ; 60$ & 4,40 & 3,40 \\
\hline $\mathrm{FeO}$ & 1.00 & 1,13 & 1,00 & $1 ; 00$ & 0,70 & 1,00 \\
\hline $\mathrm{K}_{2} \mathrm{O}$ & 7,90 & $6,8 j$ & 6,00 & 4,00 & 3,70 & $4 ; 00$ \\
\hline $\mathrm{Na}_{2} \mathrm{O}$ & 1.80 & 1,63 & 1,30 & 0,20 & 0,10 & $0,10$. \\
\hline $\mathrm{MgO}$ & 0,08 & 0,13 & 0,10 & 0.09 & 0,08 & 0,09 \\
\hline $\mathrm{MnO}$ & 0,03 & 0,03 & $0 ; 03$ & 0,04 & 0,03 & 0,04 \\
\hline $\mathrm{CaO}$ & 1,00 & 1,00 & $0: 08$ & $0 ; 36$ & $0 ; 05$ & 0,45 \\
\hline $\mathrm{TiO}_{2}$ & 0110 & 0,10 & 0,10 & 0,20 & 0,20 & 3,20 \\
\hline $\mathrm{P}_{2} \mathrm{O}_{5}$ & 0,05 & 3,35 & 0,36 & 0,07 & 0,07 & 3,06 \\
\hline $\mathrm{H}_{2} \mathrm{O}-$ & 0,16 & 0,04 & 0,08 & $0,14 \ldots$ & $-3,30$ & 1,14 \\
\hline $\mathrm{H}_{2} \mathrm{O}+$ & 0,34 & 1,48 & 3,70 & $4 ; 50$ & 11,31 & 7,36 \\
\hline Total & 79,63 & 77,30 & 101,55 & 131,70 & 78,43 & 38,74 \\
\hline Dens. apar. & 2,62 & 2,58 & 1,79 & 1,44 & 1,47 & \\
\hline Cuartzo & 31,3 & 31,8 & 33,8 & 38.7 & & \\
\hline $\mathrm{SiO}_{2}$ & & $-6,7$ & $-40,1$ & $-72,2$ & & \\
\hline $\mathrm{Al}_{2} \mathrm{O}_{3}$ & & $+1,8$ & $+5,8$ & $+1,6$ & & \\
\hline Fe total & & $+44,1$ & $+42,4$ & +37.2 & & \\
\hline $\mathrm{K}_{2} \mathrm{O}$ & & $-15,4$ & $-37,7$ & $-72, J$ & & \\
\hline $\mathrm{Na}_{2} \mathrm{O}$ & & $-12,8$ & $-44,7$ & $-93,6$ & & \\
\hline $\mathrm{MgO}$ & & - & - & $-50, j$ & & \\
\hline $\mathrm{CaO}$ & & - & $-72,3$ & $-36,1$ & & \\
\hline $\mathrm{H}_{2} \mathrm{O}$ total & & +200 & +500 & +400 & & \\
\hline
\end{tabular}


TABELA 6

Composição granulométrica do perfil IT-2

\begin{tabular}{|c|c|c|c|c|c|c|c|c|}
\hline Horizontes & $\begin{array}{l}\text { Profu } \\
\text { em }\end{array}$ & $\begin{array}{l}\text { ndidade } \\
\mathrm{cm}\end{array}$ & $\begin{array}{c}\text { Cascalho } \\
\%\end{array}$ & $\begin{array}{c}\text { TERRA } \\
\text { Areia } \\
\text { Grosaa } \\
\%\end{array}$ & $\begin{array}{c}\text { FINA } \\
\text { Areia } \\
\text { Fina } \\
\%\end{array}$ & $\begin{array}{l}\text { SECA } \\
\text { Joimo } \\
\%\end{array}$ & $\begin{array}{l}\text { O } k_{2} R \\
\qquad \times g_{\%}\end{array}$ & $\begin{array}{l}\text { Classc } \\
\text { textura) } \\
\text { da TFS. }\end{array}$ \\
\hline$A_{1}$ & 0 & -11 & 25,5 & 29.9 & 31,2 & 7,7 & 5,5 & $\begin{array}{c}\text { Fino } \\
\text { arenoso }\end{array}$ \\
\hline$G_{1}$ & 11 & -38 & 7,6 & 39,2 & 27,2 & 6,5 & 19,5 & $\begin{array}{c}\text { Areno } \\
\text { barrente }\end{array}$ \\
\hline $\mathrm{G}_{2}$ & 38 & -90 & 3,3 & 41,3 & 23,5 & 8,8 & 23,2 & $\begin{array}{c}\text { Areno } \\
\text { barrenti }\end{array}$ \\
\hline$c_{1 \mathrm{fas}}$ & 90 & -125 & 5,0 & 40,8 & 23,6 & 6,6 & 22,5 & $\begin{array}{l}\text { Areno } \\
\text { barrento }\end{array}$ \\
\hline $\mathrm{s}^{\mathrm{k}} \mathrm{C}_{2}$ & 125 & $-\quad ?$ & 40,0 & 31,6 & 12,4 & $4 ; 4$ & 11,6 & $\begin{array}{l}\text { iscono } \\
\text { barrento }\end{array}$ \\
\hline
\end{tabular}

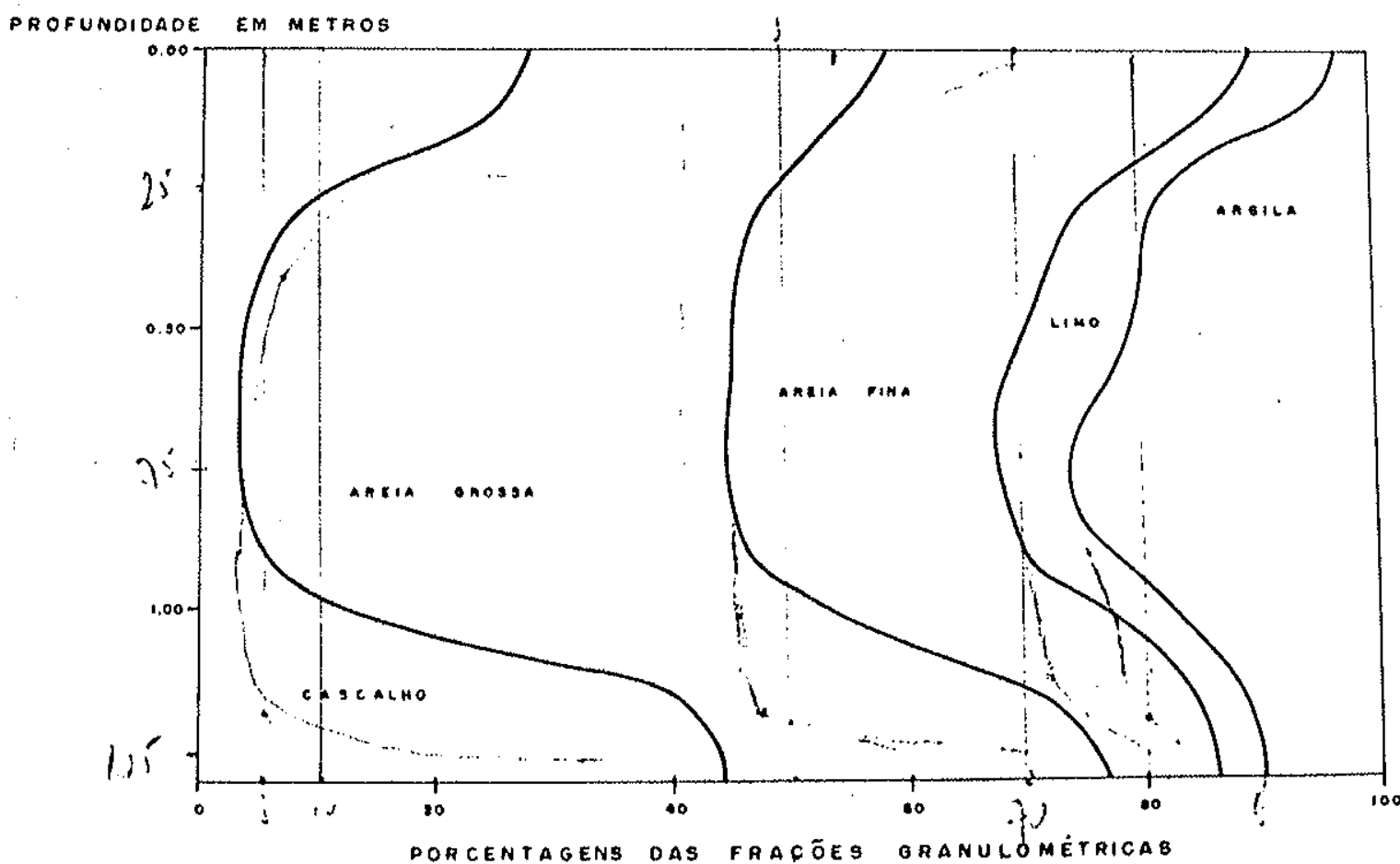

- Fig. 23 * Distribuição das frậ̃es granulométricas ao loago do perfil IT -2 . 
$50 \%$ do material total.

B - Análise mineralógica do perfil

IT -24

Rocha inalterada, idêntica à do perfil anterior. Esta amostra foi coletada próxima ao pexfil, pois êste não atingiu a rocha fresca.

E um granito róseo, de textura equigranular grossa. constituído de grandes cristai s de faldspato potás sico. São comuns os intercrescimentos pertíticos e micropertíticos. O quartzo, segundo mineral em abundância mostra sempre grande quantidade de bolhas de gás, exibindo normalmente extinção ondulante. Cristais idiomorfos e hipidiomorfos de plagioclásios geralmente aparecem com tamanhos sempre inferiores ao do quarto e feldspato potássico. Constituem o terceiro mineral em quantidade. Apresentam composição que varia de $\mathrm{Ab}_{90} \mathrm{An}_{10}$ a $\mathrm{Ab}_{75} \mathrm{An}_{25}$ e possuem gemina ção do tipo albita combinada com a de Caxlsbad.

A biotita, como no granito do perfil anterior, é écassa, apresentando-se em parte transformada em clorita, possîvelmente por ação de processos hidrotermais.

Os principais acessórios øão: apatita, zirconita, rutilo e opacos, principalmente ilmenita e magnetita.

A análise modal é pràticamente idêntica à rocha do perfil anterior, podendo esta amostra ser classificada como alasqui to. Sua textura e sua densidade são também semelhantes, de modo que consideramos sua composição química igual à anterior.

Não foi possível obter-se nesta amostra o estádio de ro 
cha parcialmente alterada, pois a transição de rocha fresca para saibro é brusca.

$$
\text { IT }-23
$$

Rocha totalmente decomposta, conservande ainda a tex tura oxiginal do granito. Este horizonte corresponde ao saibro.

No perfil IT-2, ao contráxio do perfil antexior, o fenô meno de arenização é bastante reduzido.

O quartzo sofre uma pequena concentração residual,em virtude de sua grande resistência ao intemperismo, não eviden ciando nenhum sinal da ação do mesmo. Constitui quase que a totalidade dos minerai s presentes nas frações cascalho, areia gros sa e areia fina. No limo sua concentração é ainda alta, o mesmo não acontecendo na fração argila (Figs. 24. 25 e 26).

O feldspato potás sico predomina nas frações grossei ras, acompanhando o quartso. Eum mineral que possui certa re sistência à ação do intemperismo. Uma parte dos grãos, já neste horizonte, perdeu sua color ação avermelhada, tornando-se esbran quiçada com visíveis sinais da alteraçäo, enquanto que a maior parte possui brilho de clivagem.

Os plagioclásios, for sua vez, apresentam uma alteração bem mais pronunciada, havendo certo decréscimo em seu teor. Os grãos mostram-se com as faces corroídas, apresentando aspecto cavernoso.

Ao microscópio, tanto os plagioclásios (principalmen te), como os feldspatos potássicos, apresentam manchas infor mes, completamente isótropas, que se desenvolvem nas clivagens, fissuras e faces dos cristais. Estas manchas são normalmente in 


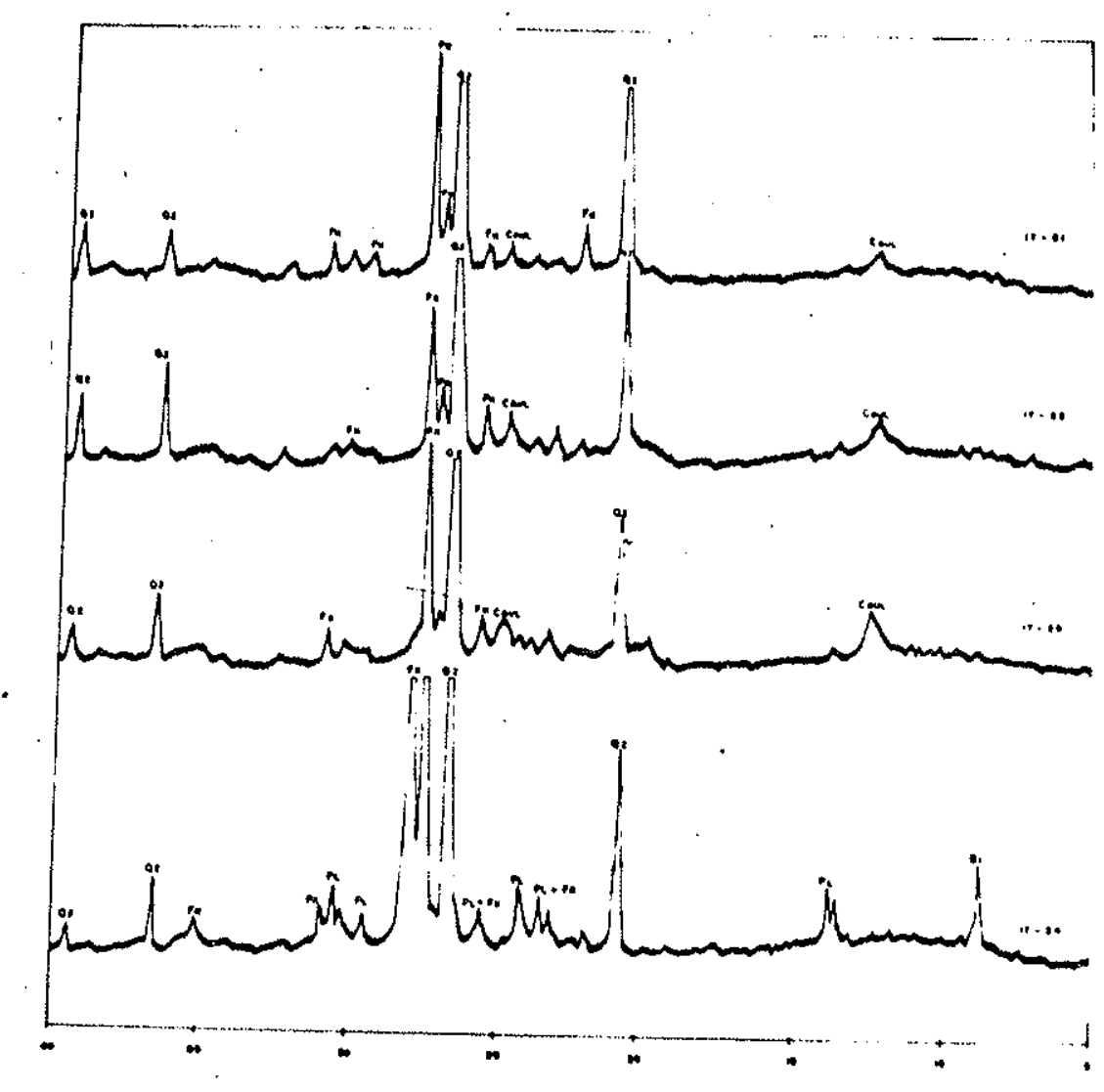

Fig. 24 - Difratogrames dos diferentes níveis de alteração do perfil IT-2. Rz(quartzo); F'K(feldspato potássico); Pl (plagioclásio); Ei(biotita); CAUL (caulinita).

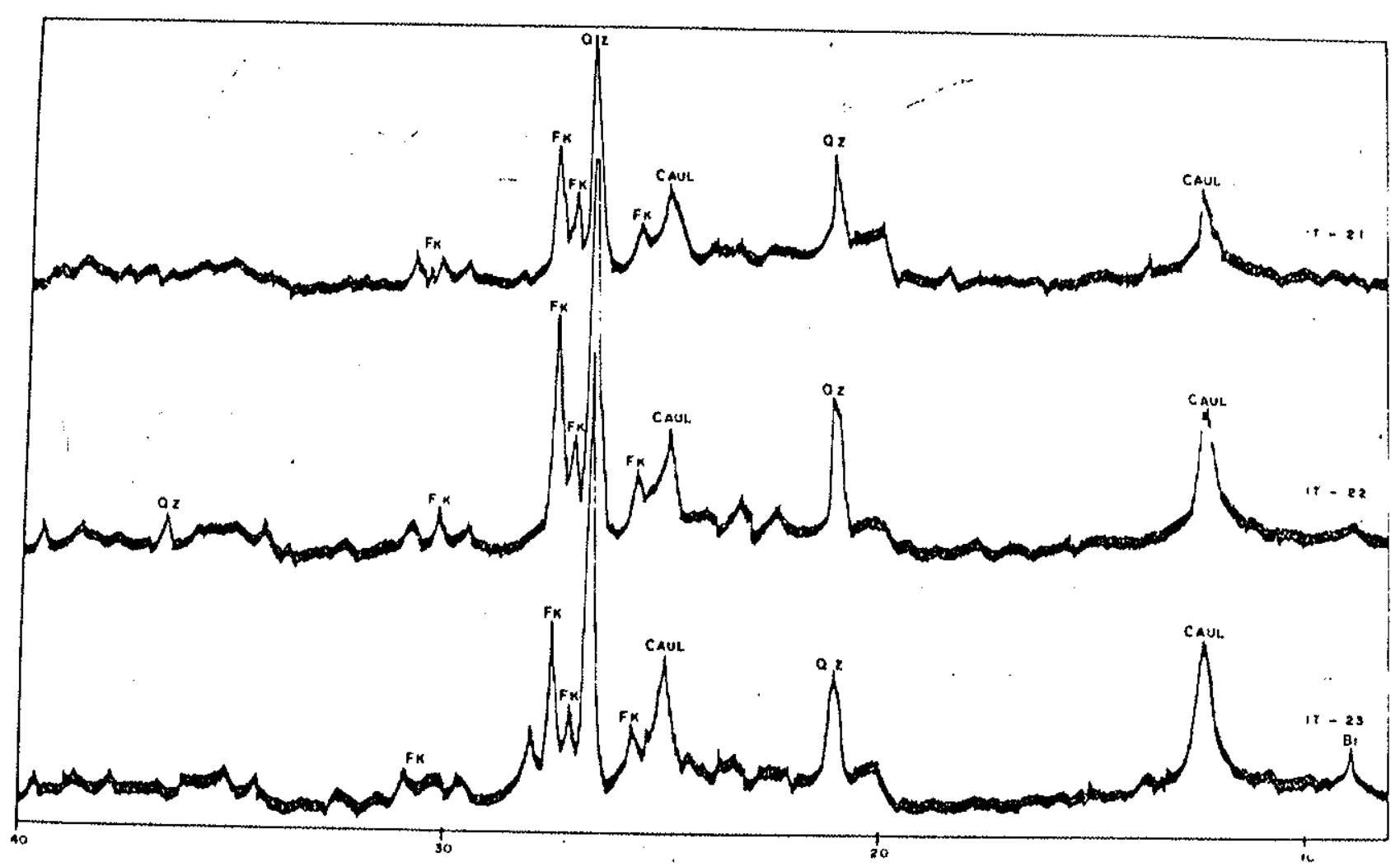

"iฐ.. 25 - Difratogramas d: fração limo $(0,02-0,002 \mathrm{~mm})$ dos diferentes níveis do pertil de altoração IT-2. 
colores, podendo às vêzes estar tingidas de vermelho, devido ao ferro liberado a partir da biotita. Este material isótropo (lígs . 27 e 28) pode ser interprevado como gel amorfo e representaria um primeiro estídio na transformação dos feldspatos, por ação do intemperismo. Associado a êste material amorfo, notamos pe $\mathrm{C}_{2}$ quenos grãos de opala, comuns nas camadas superiores. $10{ }^{13}$ ?

A biotita sofre uma acentuada diminuição, apresentando-se, em parte, al terada em vermiculita. A clorita, que apare ce em teores baixos na rocha fresca, continua neste horizonte com um teor aproximadamente constante, em virtude de possuir certa estabilidade nas condições superficiais.

A caulinita é o primeiro mineral de neoformação a sux gir no perfil. Encontra-se concentrada nas frações limo e argila se bem que pode ocorrer em pequenas quantidades na fração areia fina. A análise cuidadosa dêsse material ao microscópio, re velou cristais de feldspatos, apresentando-se alterado parcial ou totalmente em caulinita (Fig. 29). A caulinita apresenta-se bem cristalizada, possuindo por vêzes tamanhos relativamente gran des, da ordem de $0,005 \mathrm{~mm}$ (Eig. 30). Esta figura revela ainda a presença de halloysita, não observada na análise dos difratogra mas de raios $X$.

$1 \mathrm{~T}-22$

Já representa um típico horizonte pedológico, desenvol vido em condições de hidromorfin.

As transformações mineral ógicas verificadas neste ho rizonte nada mais são di qué as osorridas no horizonte anterior, havendo sòmente vaxiações quantitativa na composição mineraló 


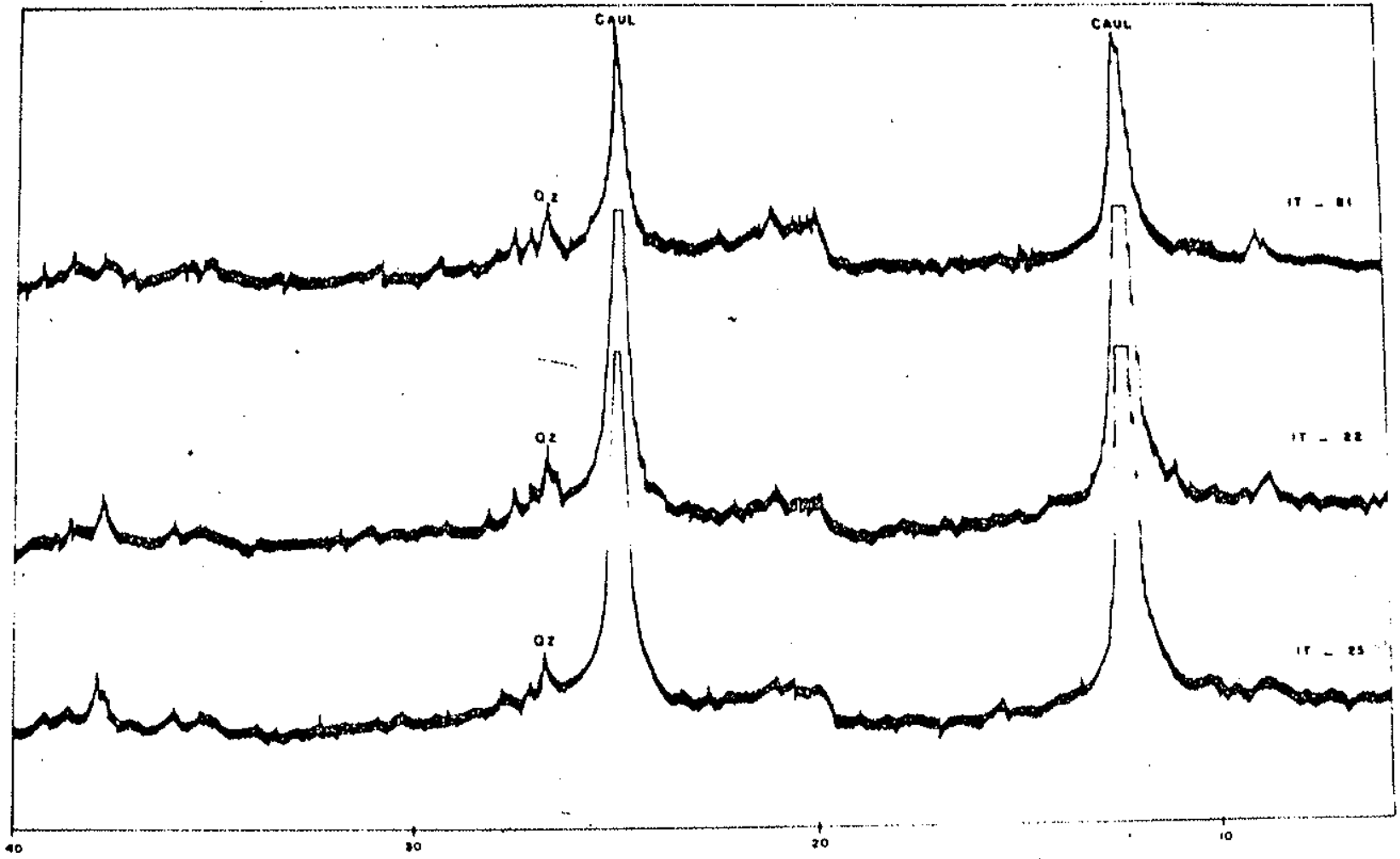

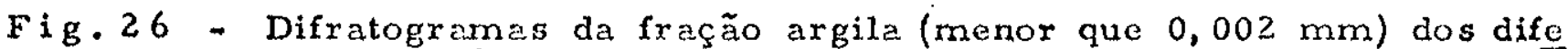
rentes estádios de alteração do perfil IT -2 .

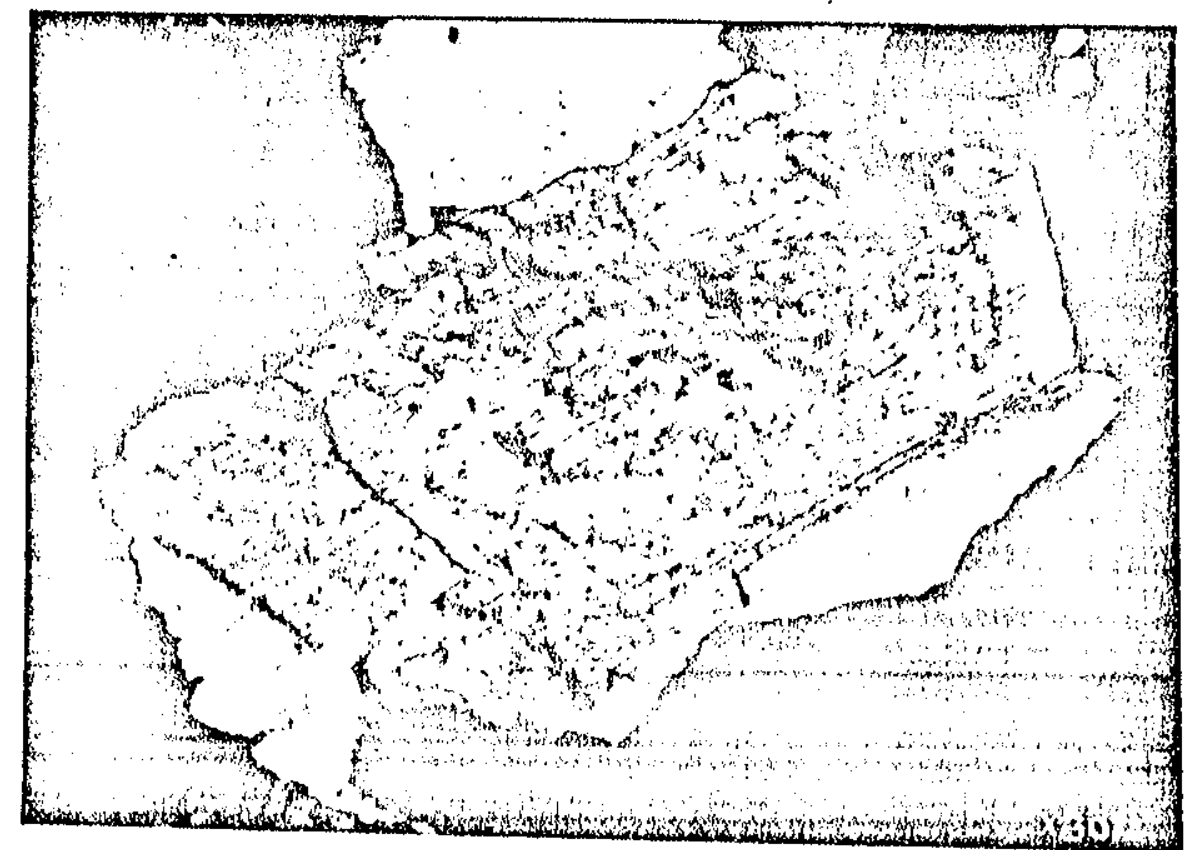

Fig. 27 - Início de alteração dos feldspatos - As fis suras são preenchidas pox gels amorfos. 


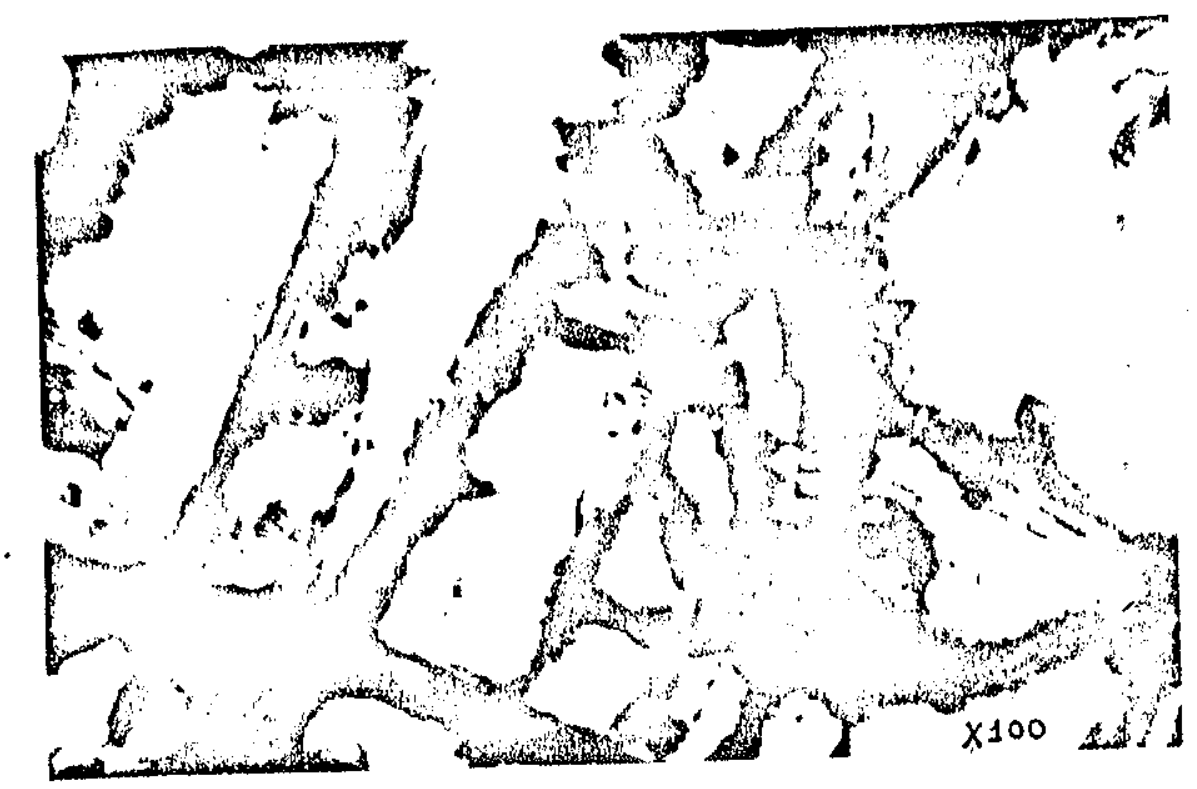

Flg. 28 - Início de alteraj $\equiv$ cos feldspatos - cristal de feldspato mostrando numerosas físuras ao redor das quais se desenvolve gels isótropos.

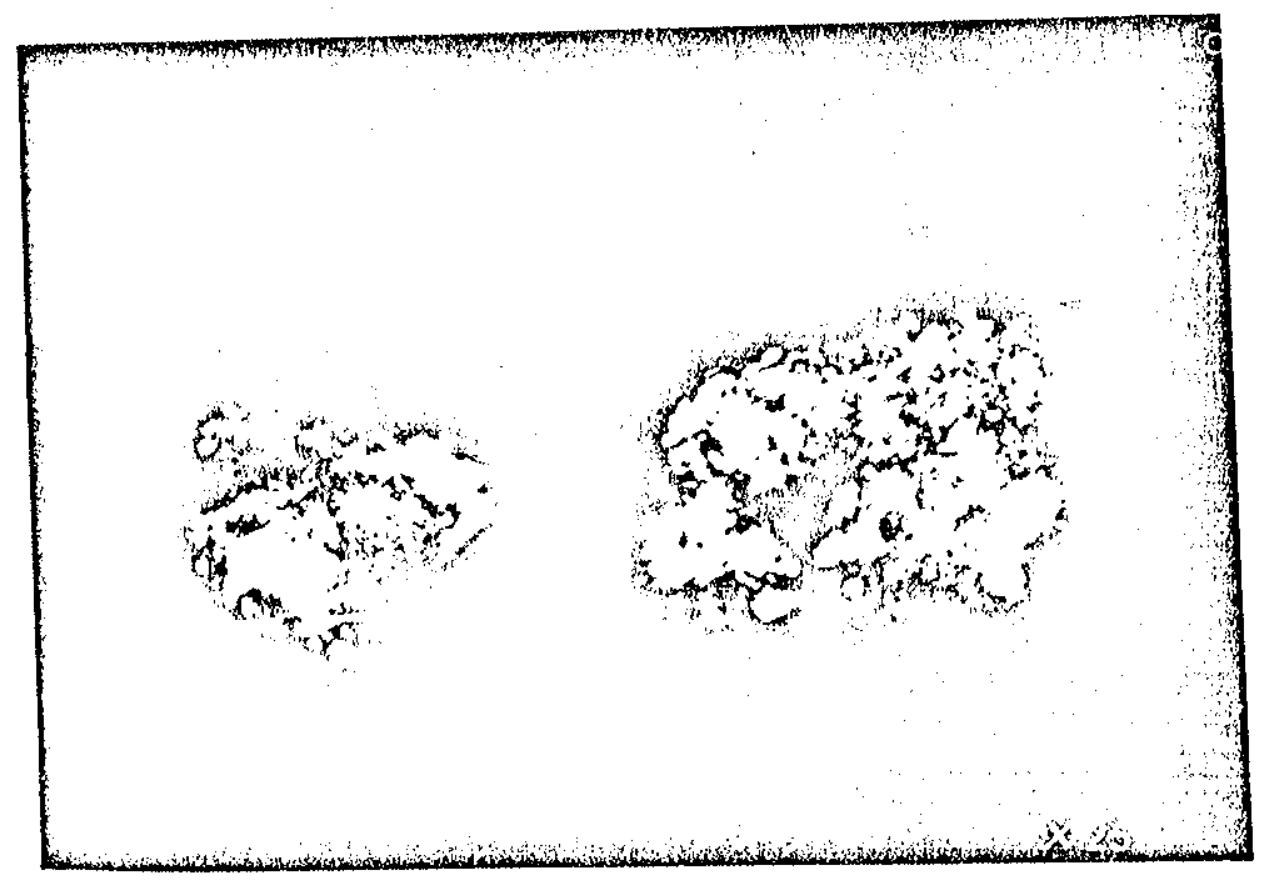

Fig. 29 - Alteração do felcepzto em caulinita: grãos de felds.. patos isolados $\Xi \equiv$ ix 2 żo areia fina do horizonte IT -23 totalmente alt $\mathrm{r} \geq 00 \mathrm{em}$ caulinita. 


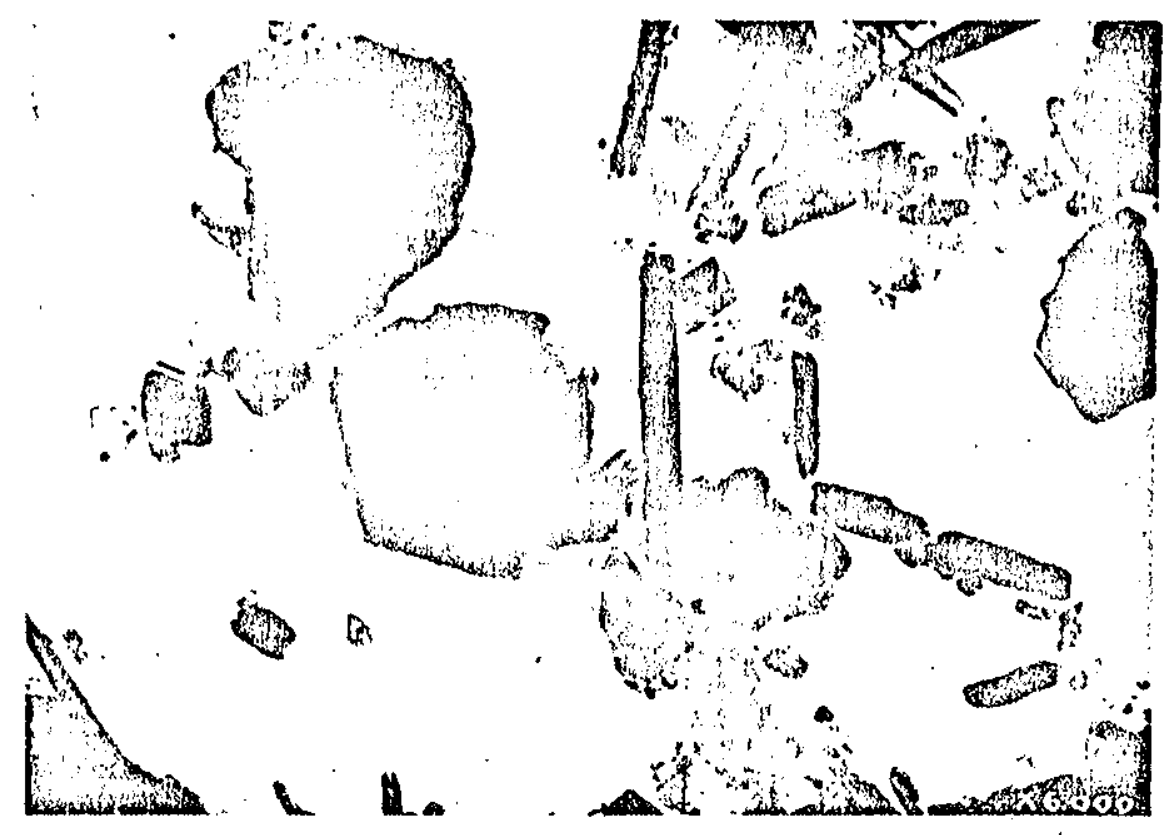

Fig. 30 - Nicrografia eletrônica da fração argila do nivel IT-22, notando-se caulinita bem cristalizada com contornos hexagonais e tubos longos e curtos de halloysita. 
gica.

O teor em quartzo 90 : zantém constante no início do ho rizonte, aumeatando xapidamonto na parte cuperior. Devido a

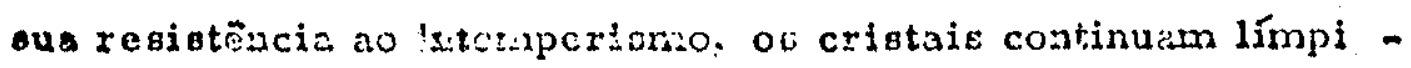
dos e sem nenhum sinal da alteração. Ocorre em maior ou me nor proporção em tôdas as frações granulomét:icas do horizonte.

O plagioclásio pràticamente desaparece do perfil, res tando apenas vestígios de sua ocorrência.

O teor em feldspato potássico decresce pouquíssimo, mostrando ser um mineral bastante estável nas condições exis tentes no perfil. Seus cristais perdem quase que totalmente a côr original e o brilho, apresentando-se translúcidos.

Ao microscópio, notamos ser ainda frequente a exis tência das manchas amorfas, se bem que mais xestritas do que no horizonte anterior. A presença de opala é ainda uma feição co mum dêste estádio de alteração.

Quase tôda a biotita se transformou em vermiculita; es ta, mais a clorita, diminui dentro do perfil, mostrando possui rem ambas certa instabilidade.

A caulinita torna-se um dos minerais mais importan tes quantitativamente dentro do horizonte, predominando nas frações argila e limo.

IT -21

E o horizonte superficial do solo. Sofre grandes contribuições de materiais estranhos ao perfil.

O quartzo contribui de $50 \%$ para o volume total do horizonte, no qual temos certamente quartzo aloctone, evidenciado pela existência de grãos"que apresentam pronunciado arrodondamento. 
O feldspato potássico contribui ainda com grande por centagem para a formação do horizonte, apresentando as mesmas caracteríoticas encontradis no nível antexior.

O plagioclásio aparece neste horizonte em quantidades insignificantes e os poucos grãos que restam estão parcialmente alterados.

Tanto a biotita como a vermiculita e a clorita pràtica mente desapareceram do perfil.

A caulinita é ainclo un dos mincrais mais importantes do horizonte, apesar de ter sofriło também uma pequena diminuiç̃o em seu teor.

A tabela 7 e a figura 31 representam os dados minera lógicos do perfil IT-2.

C - Análises Químicas

As análises químicas e os cálculos isovolumétricos dos diferentes horizontes do perfil IT-Z são apresentados na tabela 8.

\section{1}

- $3-$ Perfil $\mathrm{MIO}-1$

\section{A - Análise granulométrica}

A observação dos resultados da tabela $9 \in$ da figura 32 revela que a passagen da roche granítica para o solo se verifica com um aumento puogressivo das frações grosseiras.

Como nos demais perfis ccletados sôbre rochas graníticas, êste é tambóm caractcrizado pela presença da fração cascatho ao longo de tode o perfil, em quantidades sempre crescente cm direção à supexfície.

A argila constitui uma pequena fração nos horizontes in 


\section{TABELA 7}

Composição mineralógica dos diferentes níveis de alteração

$$
\begin{aligned}
& \text { do perfil IT-2 em } \% \text { (volume) } 1 / 38 \text { m } \\
& \text { IT-2, } \quad \text { IT }-23<2 \text { IT }-22-5 T^{9} \text { IT-21-4T } A_{1}(0-11)
\end{aligned}
$$

Quartzo

31

Feldspato $k$

$$
51
$$

14

Plagioclásio

Biotita

$$
1,5
$$

?

394 .

Caulinita

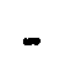

12

Halloysita

Vermiculita

Opala

Acessórios

2,5

4

29

4

1

23

tr.

1

1

3

9

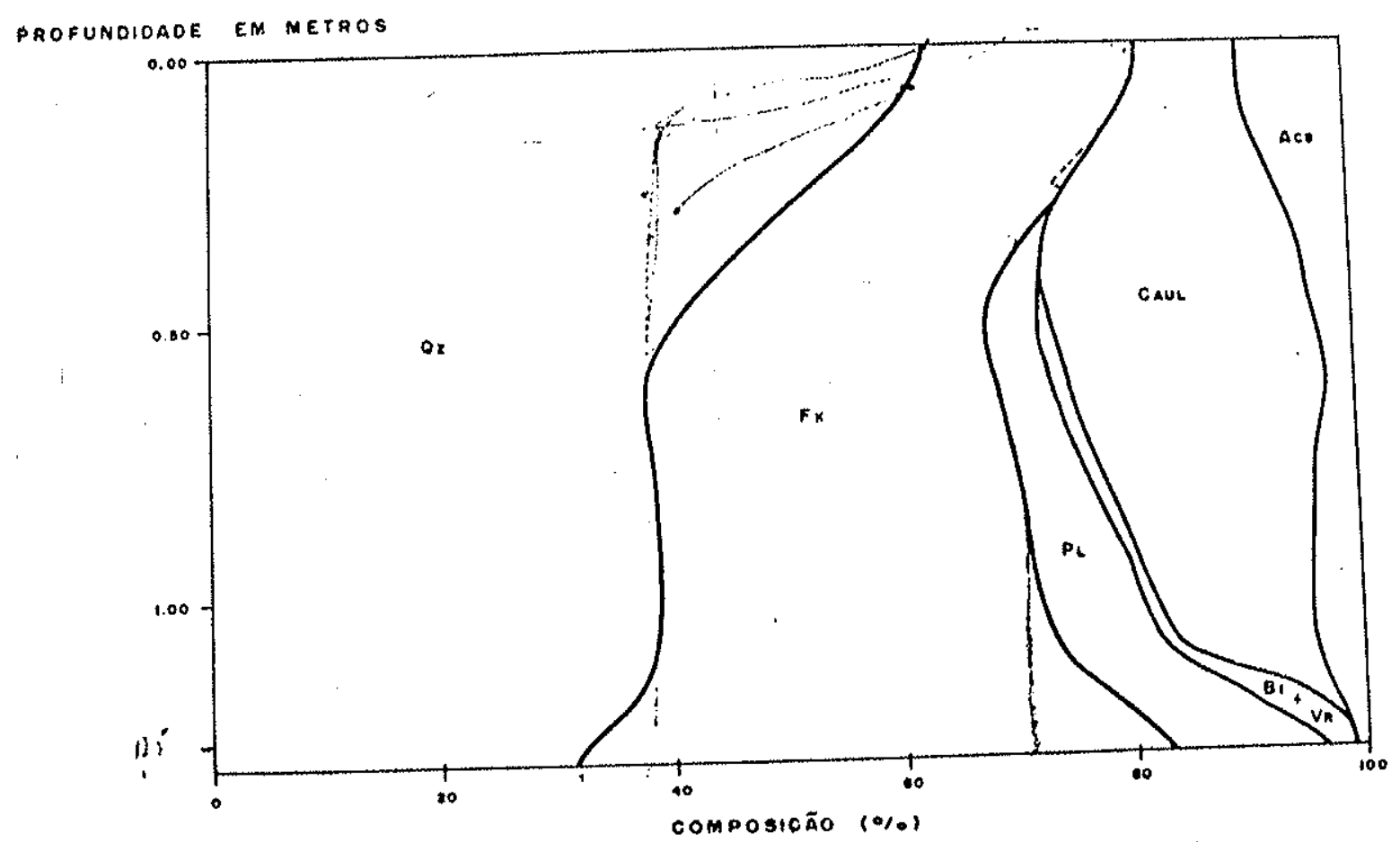

Fig. 31-Esquema mineralógico do perfil IT-2. 
TABELA 8

Análise $\mathrm{B}$ qúmicas totais do perfil $\mathrm{IT}-2$ (porcentagem pêso) e porcentagens a volume constante calculadas a partir das análises químicas

\begin{tabular}{|c|c|c|c|c|}
\hline $\mathrm{SiO}_{2}$ & $\begin{array}{l}\text { IT }-24 \\
71,40\end{array}$ & $\begin{array}{l}1 T-23 \\
68,30\end{array}$ & $\begin{array}{l}1 T-22 \\
69,80\end{array}$ & $\begin{array}{l}1 \mathrm{~T}-21 \\
70,80\end{array}$ \\
\hline $\mathrm{Al}_{2} \mathrm{O}_{3}$ & 14,50 & 19,40 & 16,30 & 12,70 \\
\hline $\mathrm{Fe}_{2} \mathrm{O}_{3}$ & 1,27 & 1,43 & 0,77 & 1,43 \\
\hline $\mathrm{FeO}$ & 1,00 & 0,57 & 0,43 & 0,57 \\
\hline $\mathrm{x}_{2} \mathrm{O}$ & 7,90 & 4,37 & 4,46 & 4,37 \\
\hline $\mathrm{Na}_{2} \mathrm{O}$ & 1,80 & 0,54 & 0,24 & nd \\
\hline $\mathrm{MgO}$ & 0,08 & 0,06 & 0,05 & 0,05 \\
\hline $\mathrm{CaO}$ & 1,00 & 0,50 & 0,34 & 0,56 \\
\hline Mino & 0,03 & - & - & - \\
\hline $\mathrm{TiO}_{2}$ & 0,10 & 0,20 & 0.28 & 0,38 \\
\hline$P_{2} O_{5}$ & 0,05 & $0,0<$ & 0,02 & 0,04 \\
\hline $\mathrm{H}_{2} \mathrm{O}-$ & 0,16 & 0,70 & 0,70 & 0,90 \\
\hline $\mathrm{H}_{2} \mathrm{O}+$ & $0,3 \hat{A}_{*}$ & 4,00 & 4,20 & 7,90 \\
\hline Total & 99,63 & 100,11 & 97,59 & 97,70 \\
\hline Dens. apar. & 2,62 & 2,51 & 2,49 & 2,41 \\
\hline Quartzo & 31,3 & 38,9 & 39,3 & 62,8 \\
\hline $\mathrm{SiO}_{2}$ & & $-12,4$ & $-11,4$ & \\
\hline $\mathrm{Al}_{2} \mathrm{O}_{3}$ & & $+28,2$ & $+6,8$ & \\
\hline FeO total & & $-16,9$ & $-49,1$ & \\
\hline$x_{2} \mathrm{O}$ & & $-46,8$ & $-46,3$ & \\
\hline $\mathrm{Na}_{2} \mathrm{O}$ & & $-70,2$ & $-87,2$ & \\
\hline $\mathrm{MigO}$ & & $-50,0$ & $-50,0$ & \\
\hline $\mathrm{CaO}$ & . & $-50,0$ & $-65,4$ & \\
\hline $\mathrm{TiO}_{2}$ & & $+6,6$ & $+13,3$ & \\
\hline $\mathrm{H}_{2} \mathrm{O}$ total & & +684 & +730 & \\
\hline
\end{tabular}


TABELA 9

Composição granulométrica do perfil $\mathrm{MO}-1$

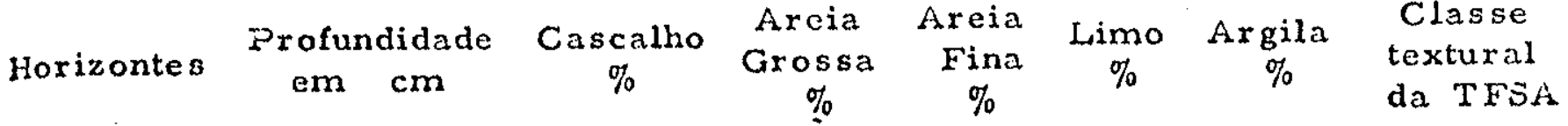

\begin{tabular}{|c|c|c|c|c|c|c|c|c|}
\hline$A_{1}$ & 0 & -6 & 39,5 & 30,3 & 11,6 & 8,0 & 10,6 & $\begin{array}{c}\text { Areno } \\
\text { barrento }\end{array}$ \\
\hline $\mathrm{A}_{2}$ & . 6 & -31 & 37,0 & 36,0, & 10,2 & 5,0 & 11,8 & $\begin{array}{c}\text { Areno } \\
\text { barrento }\end{array}$ \\
\hline$B_{1}$ & 31 & -45 & 35,0 & 20,0 & 13,0 & 11,1 & 20,9 & Barrento \\
\hline${ }^{B} 21$ & 45 & -90 & 29,6 & 17,4 & 11,0 & 15,6 & 26,4 & Barrento \\
\hline$B_{2.2}$ & 90 & -145 & 23,0 & 18,9 & 14,4 & 15,6 & 28,6 & Barrento \\
\hline $\mathrm{B}_{31}$ & 145 & -160 & 23,0 & 16,5 & 18.9 & 17,4 & $2 x_{x}, 2$ & $\begin{array}{l}\text { Fino aren } \\
\text { bartento } \\
\text { Fino aren }\end{array}$ \\
\hline$c_{1}$ & $160^{\circ}$ & -180 & 22,0 & 17,9 & 27,2 & $18,8^{\prime}$ & 14,1 & $\begin{array}{c}\text { barrento } \\
\text { Fino }\end{array}$ \\
\hline $\mathrm{C}_{2}$ & 180 & -300 & 18,0 & 28,0 & 29,6 & 15,2 & 9,2 & $\begin{array}{c}\text { arenoso } \\
\text { Fino }\end{array}$ \\
\hline$D$ & 300 & -400 & 21,0 & 14,6 & 34,3 & 23,2 & 6,9 & arenoso \\
\hline
\end{tabular}

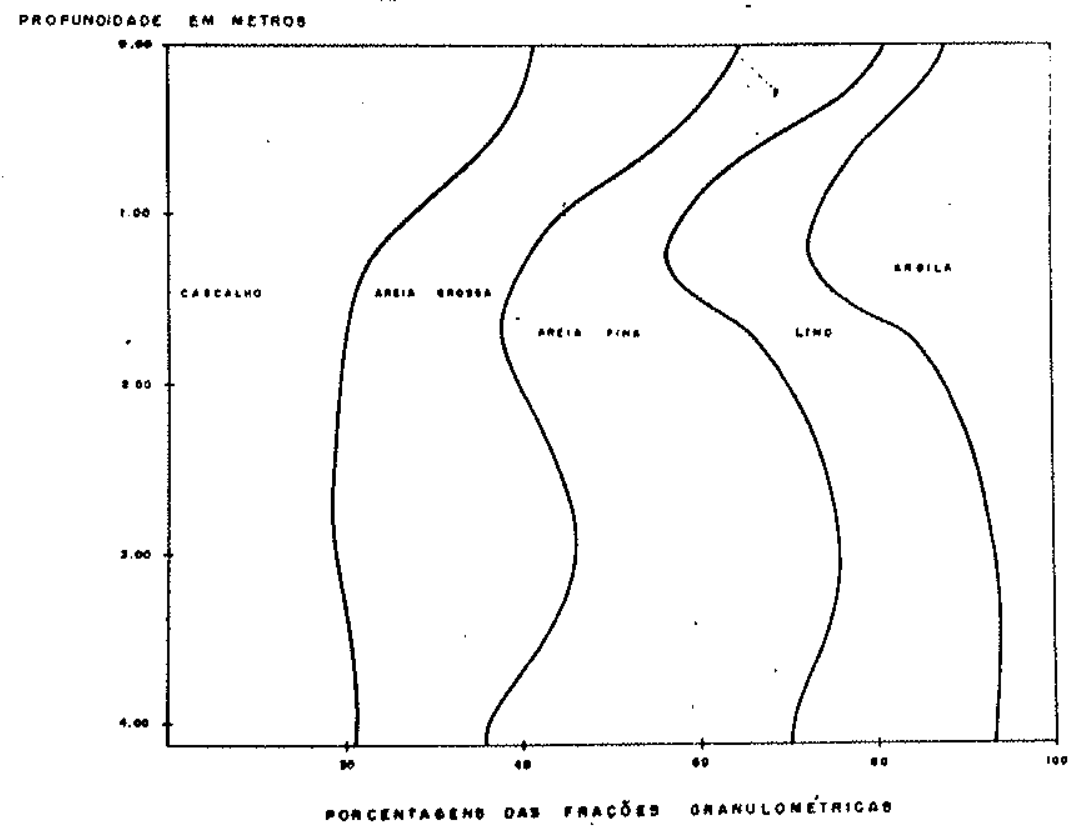

Fig. 32 - Distribuição das frações granulométricas ao longo do perfil $\mathrm{MO}-1$. 
feriores do perfil, sofrendo um rápido aumento no horizonte B do solo.

As frações intermediárias (areia fina e limo), que no $\underline{i}$ nício da decomposição constituem cêrca de $60 \%$ do material total diminuem em dirę̧ão ao tôpo do perfil, sendo que g's horizonte su perficial $A_{1}$ não atingem a $20 \%$.

\section{B - Análise mineralógica do Perfil}

$$
\mathrm{MO}-15
$$

Rocha fresca. Granita leucocrático, de granulaçãos grossa equigranul ax:

Sua composição mineralógica é a seguinte: microclí nio, que constitui $35,5 \%$ do volume total da rocha; apresenta- se sob a forma de grandes cristais que mostram geralmente o típi co gradeamento do microclínio. O quartzo, segundo mineral em abundância, constitui $32,4 \%$ do volume da rocha; seu tamanho é sempre menor quc o do feldspato e apresenta-se límpido, com i númeras inclusões gasosas, O plagioclásio constitui $28,6 \%$; possui tamanho inferior ao do quartzo e apresenta composição que varia entre $\mathrm{Ab}_{90} \mathrm{An}_{10}$ a $\mathrm{Ab}_{80} \mathrm{An}_{20}$. A biotita é escassa, consti tuindo apenas $2 \%$ do volume total da rocha. Parte desta biotita encontra-se alterada hidrotermalmente em clorita. Os acessó rios formam $1,5 \%$ da rocha, sendo a titanita o principal, com opacos, zircão e apatita subordinadamente. Como mineral secun dário, temos o epídoto, que ocorre preenchendo fraturas da rocha. 


\section{MO - 14}

Este horizonte corresponde ao saibro, rocha totalmente alterada. O processo de arenização neste perfil é bastante in tenso.

O quartzo se mantém constante, não sofrendo a ação do intemperismo. E o principal constituinte das fraçōes grosseiras O feldspato potássico apresenta um pequeno decrésci mo em seu teor, assim como os plagioclásios. Estes últimos pos suem pràticamente todos os seus cristais com as faces corró das.

Os plagioclásios, mais intensamente, e os feldspatos potássicos apresentam neste estádio a formação de gels amorfos, mas não com a intensidade apresentada no pexfil anterior. Estes gels ràpidamente evoluem para caulinita, que é o primeiro mineral formado pela ação do intemperismo (Fig. 33).

A caulinita, além de aparecer de forma incipiente noo cristais de feldspatos das frações areia grossa e areia fina (Fig. 34) é ainda o mineral predominante das frações argila e limo (Figs. 35 e 36), ao lado de quartzo, feldspatos e biotita.

Tanto a biotita, como a clorita sofrem uma redução não só $\mathrm{cm}$ teor, mas também em tamanho, concentrando-se nas frações finas. Parte da biotita já se apresenta alterada em vermi culita, que não foi detectada nos difratogramas de raios $\mathrm{X}$ das frações estudadas, sendo sòmente observada quando do estudo do material micáceo isolado.

Por meio de microscopia cletrônica, foi constatada nes te horizonte quantidades apreciáveis de halloysita, que por difi culdades técnicas não pôde sex analisada quantitativamente (Figss. 


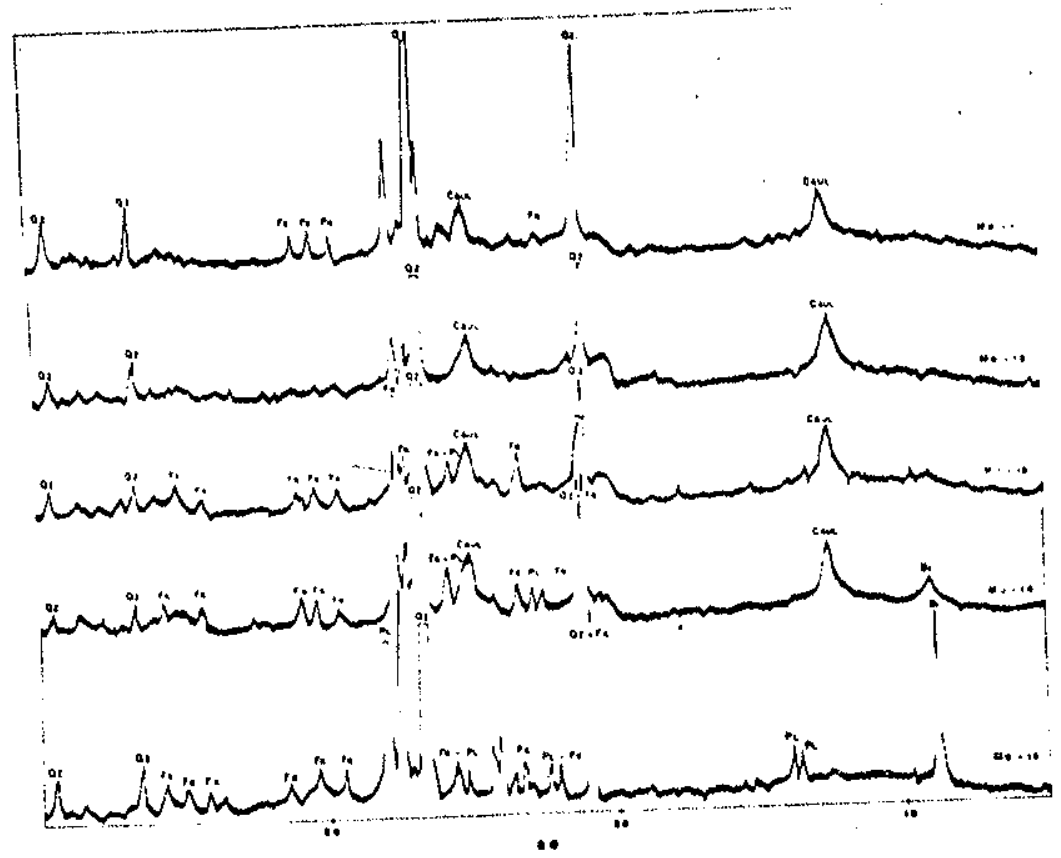

Fig. 33 - Difratogramas dos diferentes níveis de alterą̧ão do perfil $\mathrm{NiO}-1$. Qz (quartzo); Fir(feldspato potássico); Pl(plagioclásio); Bi(biotita); CAUL(caulinita); Gb (gibbsita).

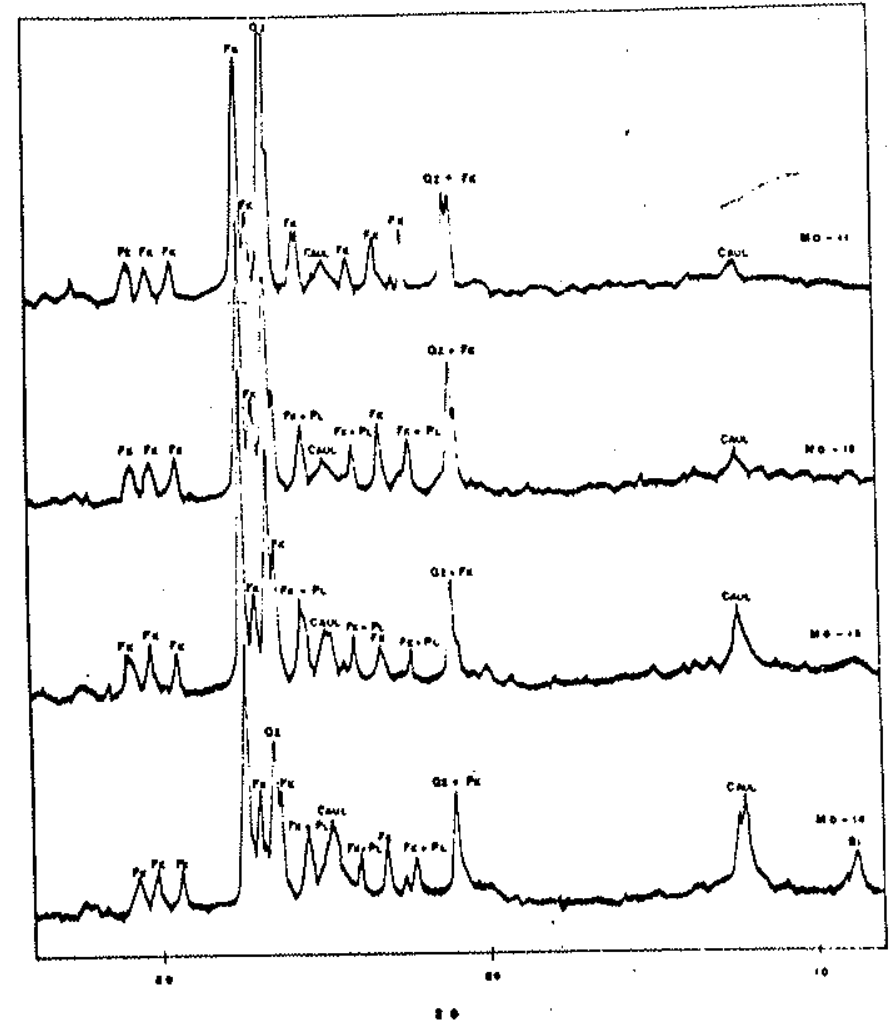

Fig. 34 - Difratogramas da fração areia fina $(0,2-0,02 \mathrm{~mm})$ dos diferentes estádios de alteração do perfil $\mathrm{Ni} O-1$. 


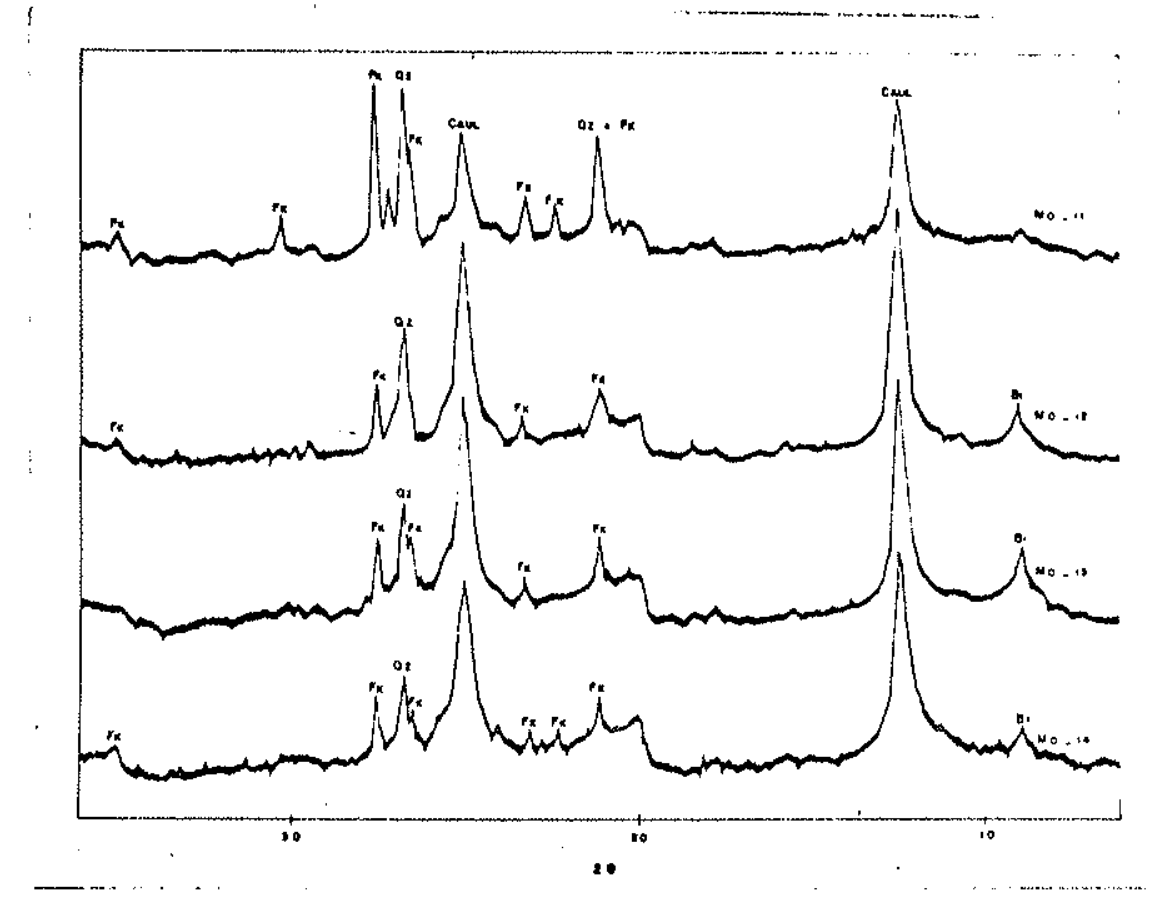

Fig. 35 - Difratogramas da fração limo $(0,02-0,002 \mathrm{~mm})$ dos horizontes do perfil $\mathrm{N}_{1} \mathrm{O}-1$.

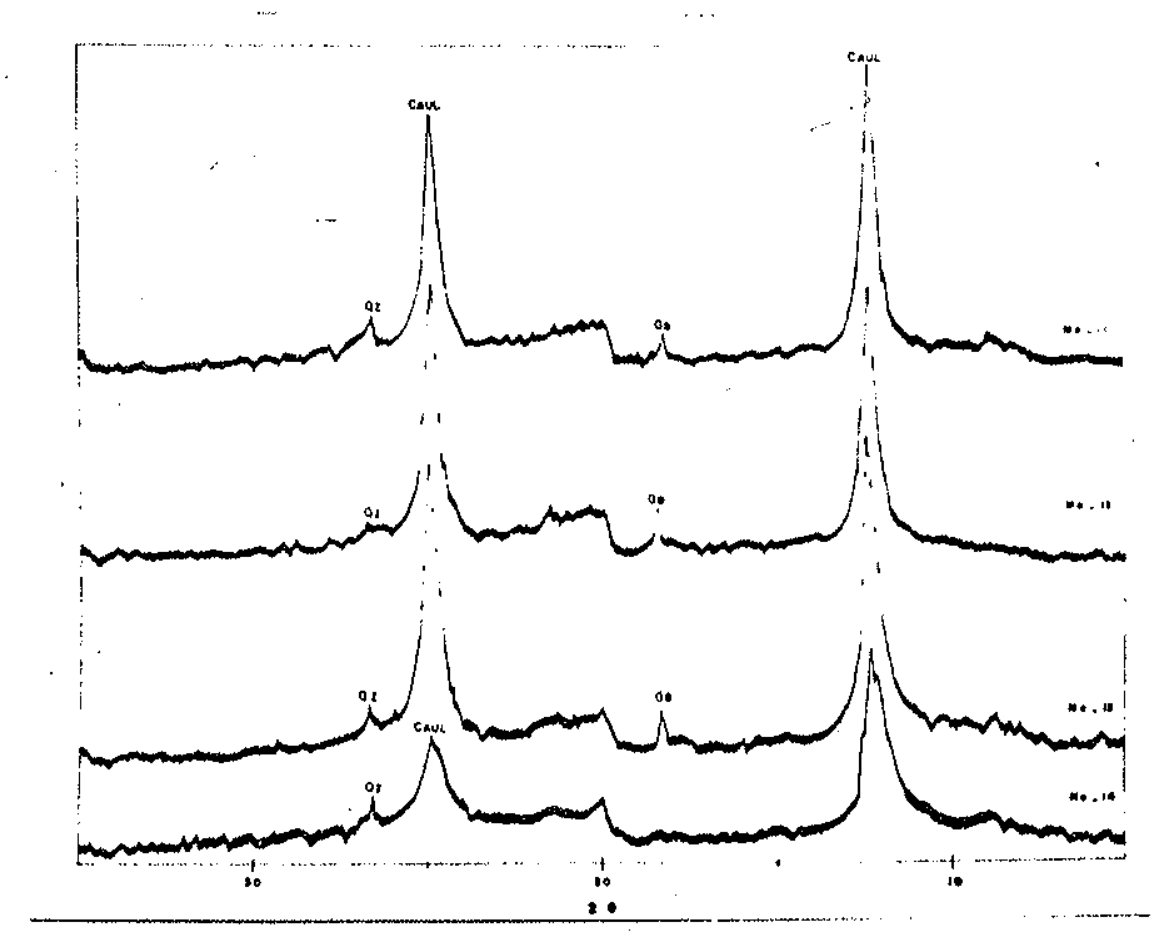

Fig. 36 - Difratogramas da fração argila (menor que $0,002 \mathrm{~mm}$ ) dos diferentes horizontes do perfil $\mathrm{MO}-1$. 
37 e 38).

\section{$210-13$}

Rocha totalmente decomposta. Este nível corresponde à parte superior do saibro. Sua mineralogia é semelhance à en contrada no horizonte anterior, havendo apenas variação nos teo res dos minerais prosentes.

Na fração argila, ao lado da caulinita, há o apareci mento de pequena quantidade de gibbsita, o que não foi notado em nenhuma outra fração.

A caulinita tem o seu teor altamente elevado, tornando-se, ao lado do quartzo, o principal mineral do horizonte.

$$
\text { MO }-12
$$

Horizonte pedológico, mostrando características for temente influenciadas pox fatôres pedogenéticos.

Os fatos mais importantes neste nível são: o total de saparecimento da biotita, acompanhado por uma diminuiçõo bas tante acentuada do teor de vermiculita e a quase total ausência dos plagioclásios.

Quartzo, caulinita e feldspato potáscico são 08 mine rais predominantes do horizonte. A gibbsita apresenta seu teor levemente aumentado, porém ainda, insuficientemente alto para ser detectado nos termogramas das frações argilas (Fig. 39)

$\mathrm{MO}-11$

E o horizonte superficial do solo, representando o es- 


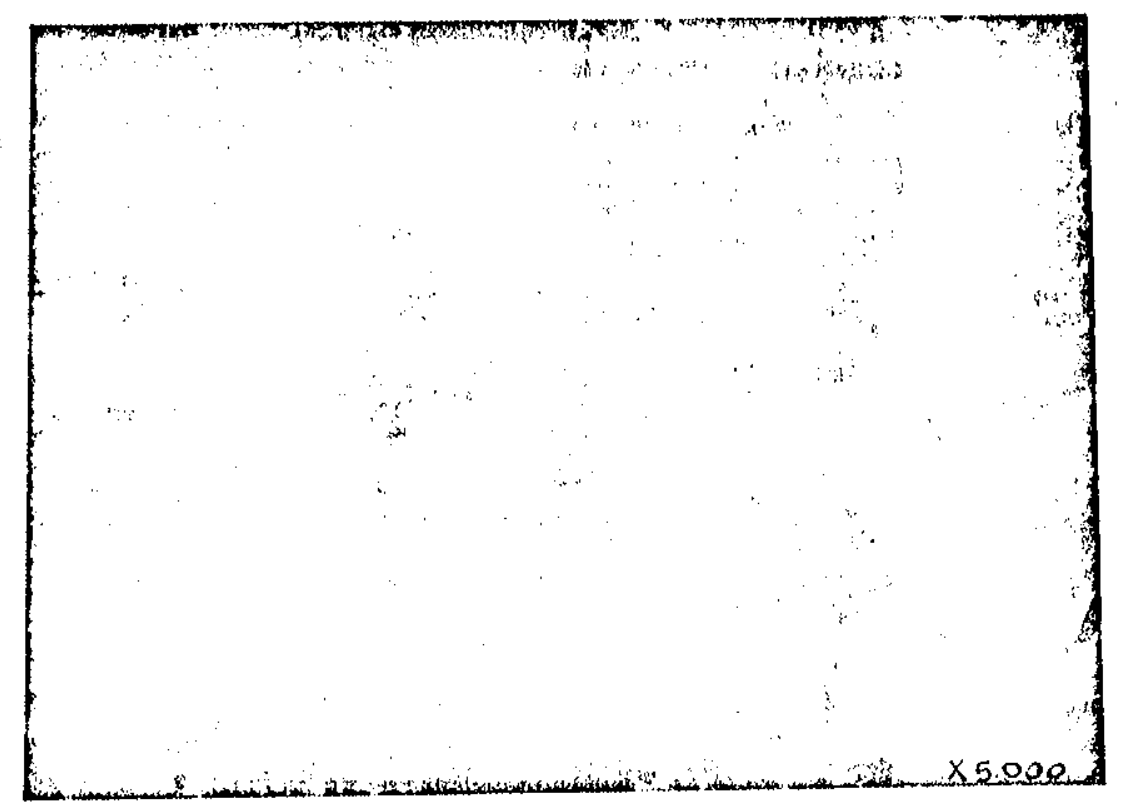

Fig. 37 - Micrografia eletrônica da fração argila do horizonte $\mathrm{MO}-14$ notando-se cristais pequenos de caulinita;poucos cristais em forma de tubos curtos de halloysita e uma grande quantidade de material amorfo.

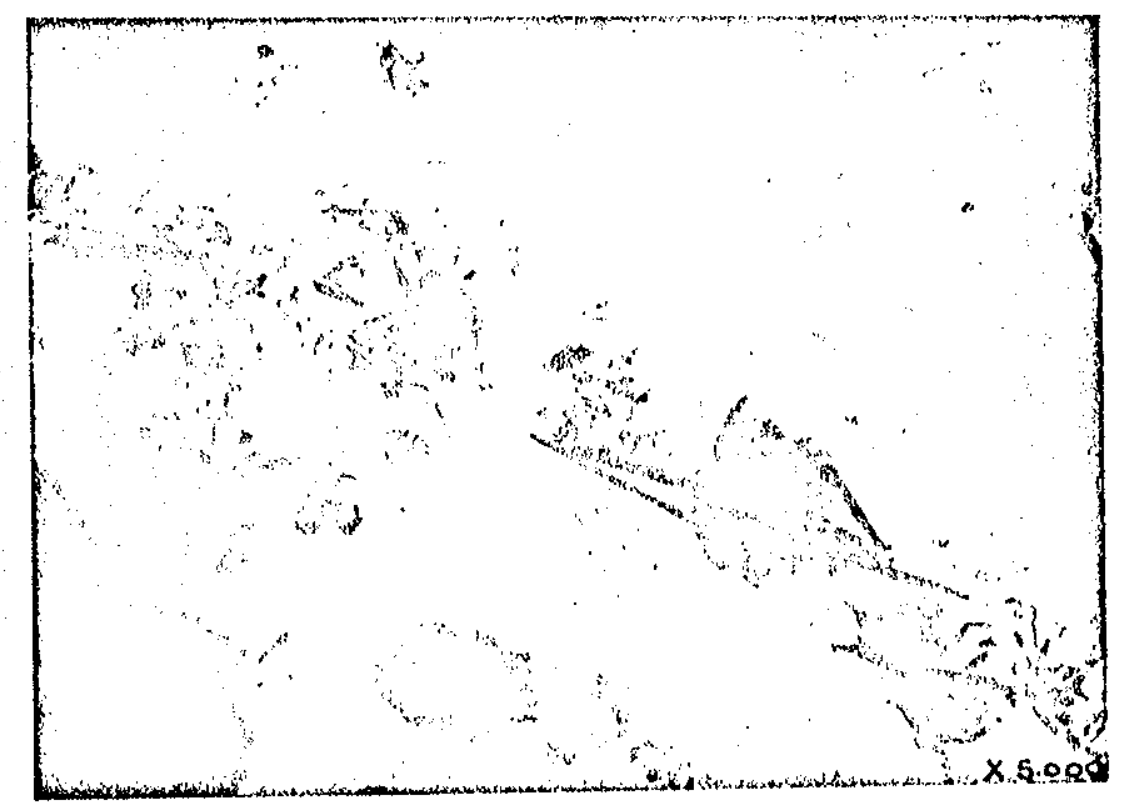

Fig. 38 - Micrografia eletrônica mostrando outro aspecto do mesmo material acima: concentração de tubos longos e finos de hal loysita. 


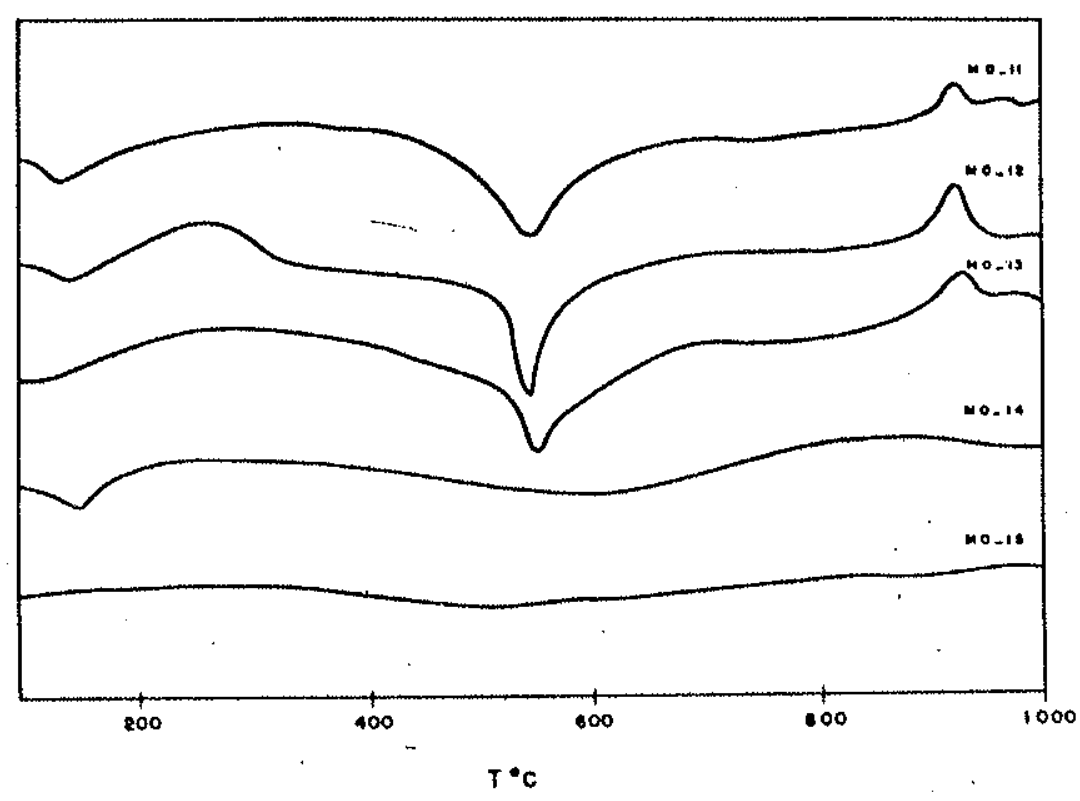

Figd 39 - Termogramas da fração argila dos diferentes níveis de alteração do per fil $\mathrm{MO}-1$. Picos endotérmicos entre
550 e $575^{\circ} \mathrm{C}$ e exotérmicos entre 920 e $960^{\circ} \mathrm{C}$ indicam a presença de caulinita. 
tádio mals avançado do intemperismo neste perfil,

Neste nível, quartzo, feldspato potássico e caulinita continuam a sex os minerais predominantes, com a diticrença que o quartzo, em relação aos horizontes anteriores, teve o seu tecr altamente elevado, principalmente por contribuição externa, cons tituindo cêrca de $50 \%$ do horizonte. O feldspato potássico também sofre um aumento de teor ocasionado pela entrada de material es tranho ao perfil.

A caulinita teve sua concentxação diminuída, enquanto que a gibbsita manteve sua concentração ao redor de $6 \%$. O plagioclásio não chega a constituir $1 \%$ do volume to tal do horizonte, e os poucos grãos que atestam sua existência mostram-se parcialmente alterados.

A tabela 10 e a figura 40 representam os dados da aná lise mineralógica do perfil $\mathrm{MO}-1$.

C- Análises Químicas

As análises químicas e os cálculos isovolumétricos dos diferentes horizontes de alteração do perfil $\mathrm{NO}-1$ são apresentados na tabela 11 . 
TABELA 10

Composição mineralögica dos diferentes níveis de alteraç̃o do pes:fil N N O l l em \% (volume)

$\mathrm{MO} .15 \mathrm{MO}-14 \quad \mathrm{NO}-13 \quad \mathrm{MO}-12 \quad \mathrm{NO}-11$

$\begin{array}{lccccc}\text { Quartzo } & 32,4 & 29 & 32 & 39 & 50 \\ \text { Feldspato i } & 35,5 & 25 & 19 & 12 & 15 \\ \text { Plagioclásio } & 28,6 & 19 & 9 & 3 & \mathrm{tr} . \\ \text { Biotita } & 2,0 & 1 & 1 & - & - \\ \text { Vermiculita } & - & 5 & 7 & 2 & 1 \\ \text { Caulinita } & - & 18 & 27 & 34 & 24 \\ \text { Halloysita } & - & \mathrm{tr} & \mathrm{tr} & \mathrm{tr} . & \mathrm{tr} \\ \text { Gibbsita } & - & - & 2 & 5 & 2 \\ \text { Opala } & - & \mathrm{tr} & \mathrm{tr} & \mathrm{tr} . & - \\ \text { Acessórios } & 1,5 & 3 & 3 & 5 & 6\end{array}$

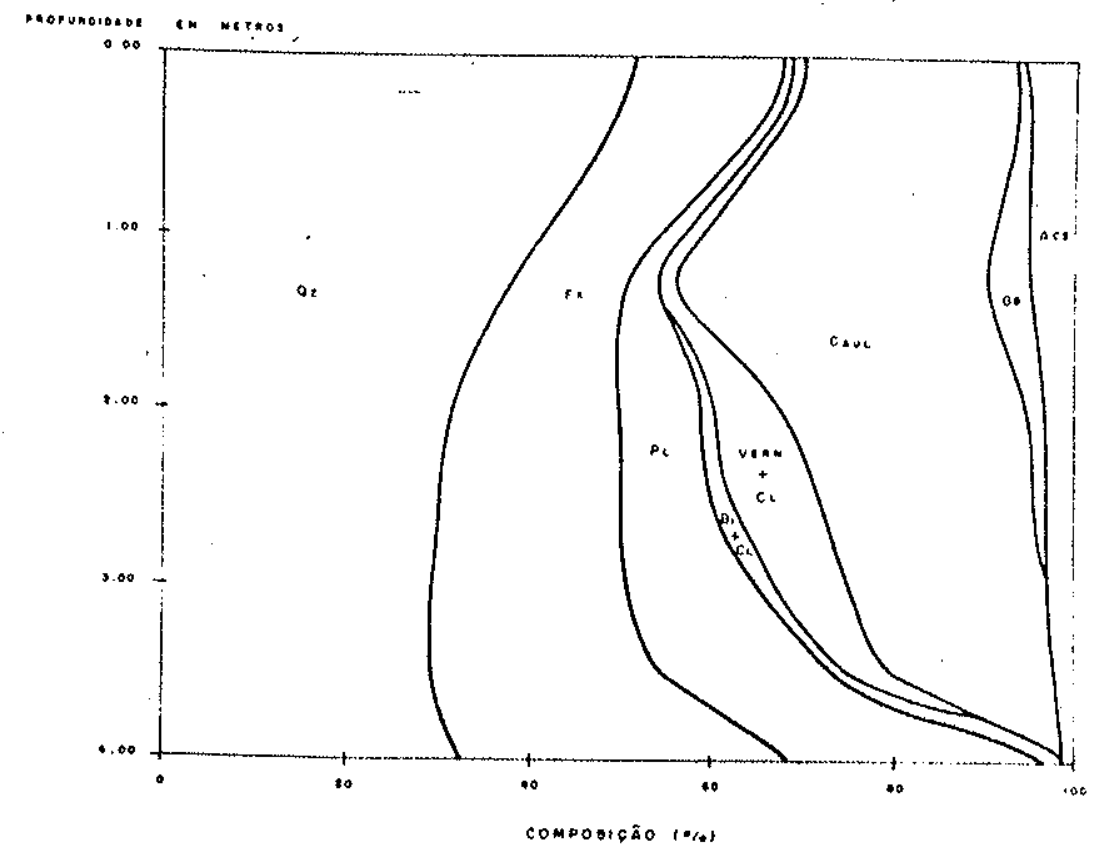

Fig. 40 - Esquema minexalógico to perfil $\mathrm{MO}-1$ 
TABELA 11

Análises químicas totais do perfil $\mathrm{N}_{\alpha} \mathrm{O}-1$ (porcentagem pêso) e porcentagens a volume constante calculadas a partir das análises químicas

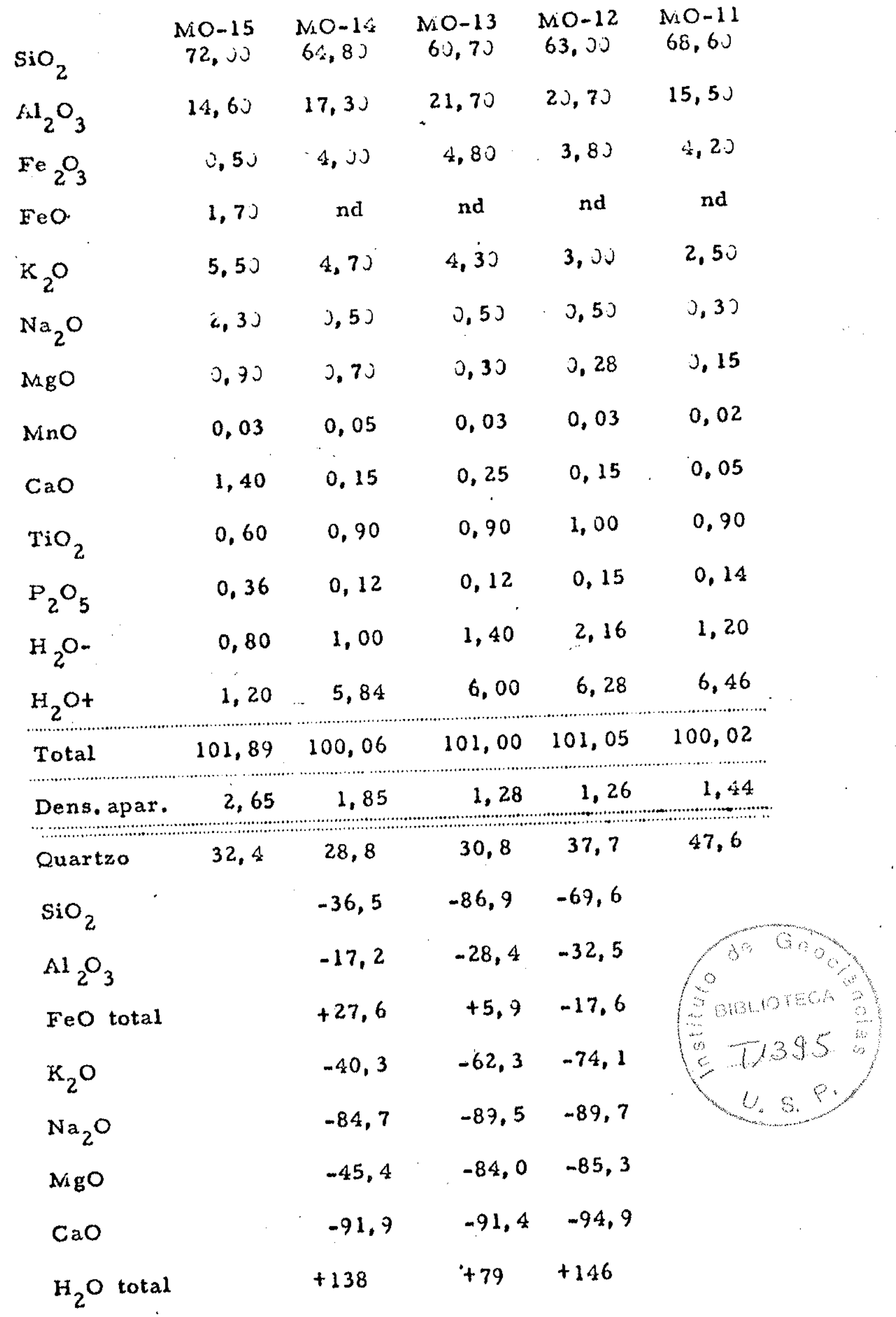




\section{CAPITULO II}

DISCUSSAO DOS RESULTADOS DO INTEMPERISMIO NOS GRANITOS E A FORMAÇAO DOS PERFIS DE ALTERAÇAO

\section{A - Análise granulométrica}

Os materiais desenvolvidos sôbre os granitos da área são constituŕdos predominantemente por frações grosseiras, que geralmente formam mais de $70 \%$ das frações totais. Este fato es-

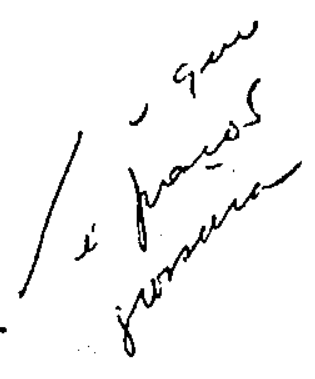
tá Antimamente ligado à alta estabilidade, nas condiçôe s superfi ciais, dos principais minerais formadores da rocha (quartzo e feldspato potássico), associado à textura grosseira da rocha que the 8 deu origem.

E caractexística dêstes solos a existência de uma fra çäo acima de $2 \mathrm{~mm}$ (cascalho) ao longo de todo o perfil, sendo mais proeminente nos perfis bem drenados e mais restrita nos mal drenados. Isto prende-se- ao fato de existir nos bem drenados maior perda das fraçōes mais finas, constituídas por minerai s fàm cilmente intemperizáveis, havendo por conseguinte um enriqueci mento das fraçōes grosseiras, formadas por minerais que apresen tam maior resistência ao intemperismo.

A fração argila é restrita ao longo de todo o perfil, com exceção do horizonte $\mathrm{B}_{2}$, onde há forte concentração da fração argila, atingindo por vêzes $25 \%$. Este fenômeno está ligado ùnicamen te a processos pedológicos de migração de argila.

\section{B - Evolução mineralógica dos perfis}

Os estudos mincralógicos e químicos dos materiais de al 
teração dos granitos mostraram que os minerais primários om portam-se de maneira mais ou menos coerente em todos os per fis analisados.

O quartzo é pouco sensível à ação do intemperismo , apresentando em todos os pexfis teor sempre crescente em dire ção à superfície, devido a esta sua estabilidade nas condições em que se realiza o intemperismo.

Por vêzes, o quartzo se apresenta na forma de grãos arredondados, arredondamento êste que parece ser devido mais ao tipo de fratura conchoidal que possui, do que a um ataque quí mico mais pronunciado nas partes salientes dos grãos. Um núme ro bem diminuto de cristais, no perfil MO-l mostra-se corrói do, o que pode indicar uma alter ação incipiente.

O feldspato potássicoé, depois do quartzo, o minexal que maior resistência oferece à ação do intemperismo, enquan to que os plagioclásios (albitamoligoclásio) apresentam resistência bem menor. Em todos os perfis, êstes dois minerai's têm suas concentrações diminuídas com a evolução do intemperismo, sendo que o plagioclásio, era todos os casos, pràticamente desar parece do perfil antes de ser atingido os horizontes superficiais.

Nos perfis desenvolvidos em condiçōes difexentea, os feldspatos apresentam comportamento diferente, sob a ação do intemperismo.

No perfil IT-1, desenvolvido em situação de boa drena gem, os feldspatos evoluem diretamente para gibbsita, que se cristaliza antes mesmo da alteração total dos feldspatos. Esta cristalização, antos da destruição totai dos feldspatos, evidencia que a gibbsita se forma ras condições de bíarólise dós minerais das rochas. O pH de abrasão para os feldspatos, determinado por 
Stevens e Carron (1948) varia de 8 a 9, e corresponde a um do mínio onde o óxido de alumínio hidratado é pràticamente insolúvel (Fig. 41).

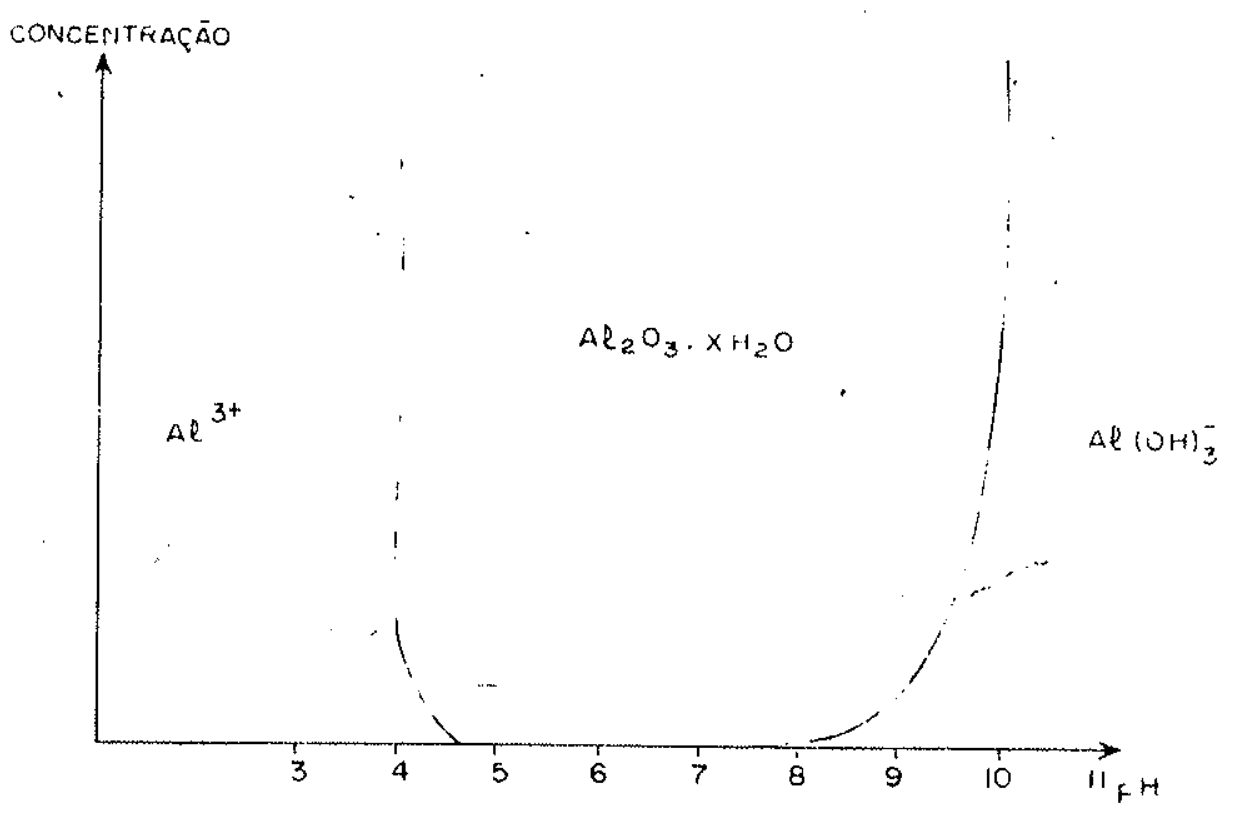

Fig. 41 - Diagrama de solubilidade do alumínio em função
do pH.

A gibbsita, que nos primeiros estádios substitui de ma neira pseudomórfica os cristais de feldspatos, apresentando al ta concentração nas frações areia fina e limo, sofre uma rápida diminuição em seu teor, associada a um aumento progressivo de sauninita. 
O fato da gibbsita apresentar uma diminuição quanti tativa crescente em direçầo à superfície, em oposição à caulini ta, que apresenta um teor cada vez major, é para nós indício de uma possível ressilicatiza äo da gibbsita, fo:tmando a caulinita. Esta evolų̧̃o parece ser bastante frẹilente no processo intempérico, tendo já side ubjero de estudo por parte de váxios auto res e interpréada como uin dos fatôres de grande importância na formação da caulinita nos solos de regiões tropicais (Del vigne, 1965; Watcon, 1965). Não encontramos porém, nenhuma evidência conclusiva e direta para provar a ressilicatização. Pa ra Schaufelberg (1951), a diminuição de gibbsita nos horizontes superiores estaria ligada à sua instabilidade na presença de ma téria orgânica, pois a complexação do alumínio com certos pro dutos orgânicos existentes no humus, podem promover sua re mobilização. Para Alexander et al. (1941), o desenvolvimento preliminar de gibbsita e o posterior de caulinita, seria devido às diferentes concentraçōes iniciais e ao curso independente da síntese da caulinita e gibbsita.

No perfil $\mathrm{NO}-1$, onde a drenagem é moderada, os feldspatos alteram-se para caulinita, havendo comumente a e xistência de um material amorfo intermediário. A caulinita per manece estável durante tôda a evolução do perfil. Com a progres são do intemperismo, forma-se gibbsita, porém em quantidades bastante baixas. Sua ocorrência apenas na fração argila faz pen sar na positili lade ce trom 3 formado a partir da caulinita, apesar de não se tar encontrado neahuma outra evidência para provar esta posizive! traneformazöo.

Na seajincia sonutra do perfil, a gibbsita apresenta um comportainento análogo do perfil anterior. 
O perfil IT-2, que evoluiu em condições de hidromorfia, mostrou que os feldspatos se alteram primeiramente em um material amorfo, o qual se transforma posteriormente em caulinita. Em alguns cristais de feldspatos, notamos transformação direta em caulinita, sem a transição para material amorfo. Es te material amorfo, encontrado por diversos autores quando a -1 teração se processa em condições de drenagem defeituosa, tem sido interpretada como alofana (Bonifas, 1959 e Delvigne, 1965). Nessas condições, a caulinita apresenta uma estabilidade razoável, sendo que associada a ela ocorre em todos os perfis maior ou menor quantidade de halloysita.

Analis ando os resultados mineralógicos es cálculos isovolumétricos obtidos nos perfis de alteração dos granitos, po demos interpretar as diferentes fases de alteração dos feldspa tos nas várias condições apresentadas (Fig. 42). Esta interpreta ção baseia-se nos trabalhos de Feth et al: (1964) e Fiess (1966), e também nos estudos geoquímicos de Garrels (1960).

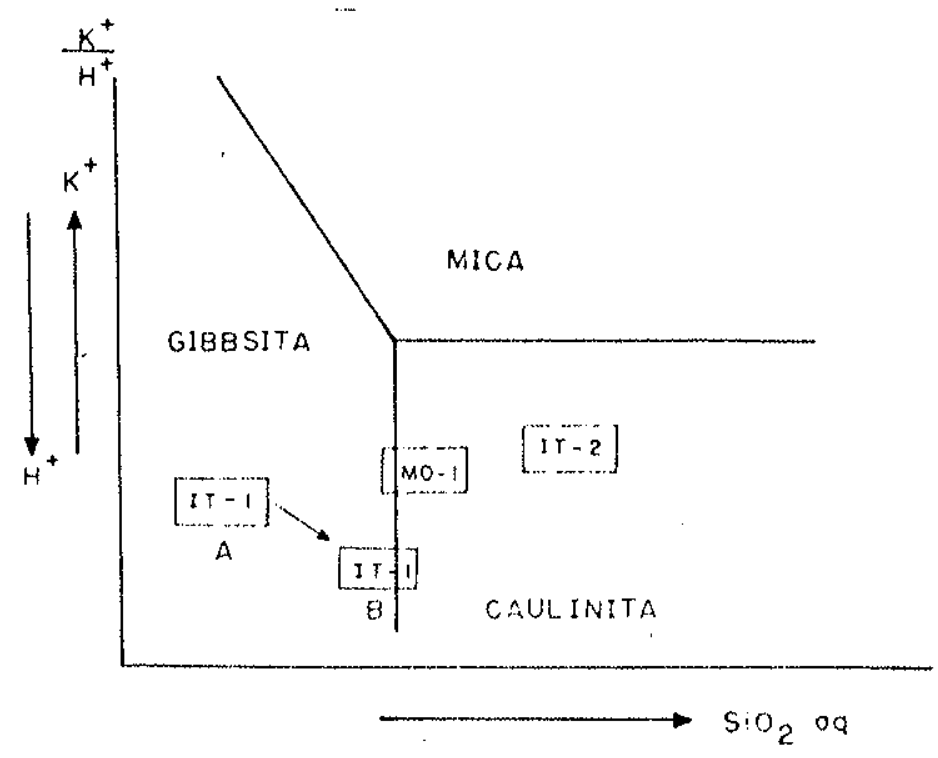

Fig. 42 - Diagrama de fase, esquemático, para o sistema $\mathrm{K}_{2} \mathrm{O}-\mathrm{Al}_{2} \mathrm{O}_{3}-\mathrm{SiO}_{2}-\mathrm{H}_{2} \mathrm{C}$ a $25^{\circ} \mathrm{C}$ e 1 atrm. de press (B) estádios posteriores de alteração. 
No caso de boa drenagem é pràticamente eliminada tôda a sílica liberada na alteração dos silicatos primários das rom chas, havendo por conseguinte baixo teor em silica disponível, e xlotindo então condições favoráveis à formação de gibbsita ou mi ca (muscovita). No caso de Urenagem defeituosa, grande parte da snica liberada na alteraçäo dos silicatos permanece no perfil, o que permite alta concentrạ̧ão de sulica na solução, criando as sim condiçōes que favorecem a formação de caulinita ou mica (musco vita).

Em ambos os casos a formação de muscovita só seria possível se o meio permanecesse alcalino, o que difícilmente acontece na alterą̧ão dêste tipo de rocha (Pedro, 1964). Conse quentemente, temos condiçōes que favorecem a formaçāo de caulinita ou gibbsita.

A biotita é outro silicato primário que se altera no decorrer do intemperismo. Apresenta certa resistência à ação intempérica, sendo ém alguns casos ligeiramente superior à dos plagioclásios sódico-cálcicos, e em outros, ligeiramente infe rior.

O primeiro estádio na alteração dạ biotita é caracterizado por pequena perda de ferro e por evidenciar certo desarran jo estrutural na análise aos rai os X. Opticamente, observa-se $\underline{u}$ ma diminuição no índice de refração, mudança de coloraçäo de marrom para amarelo-pardo, e ligeiro decréscimo do valor do ângulo entre 08 eixos ópticos. A êste material, resultarte da alte ração parcial da biotita por ação do intemperismo ou por ação hi drotermal, tem sido reservado o nome de hidrobiotita (Gruner . 1934) ou bauerita (designação não mais utilizada). A hidrobiotita, segundo Barahad (1948), pode ràpidamente converter-Be em ver - 
miculita por lavagem com $\mathrm{MgCl}_{2}$.

A vermiculita, que nos níveis inferiorea do solo sofre uma pequena concentração, nos estádios mais avançados de in temperismo se torna instável formando caulinita ou gibbsita, con forme condições locais em que se verifica a alteração.

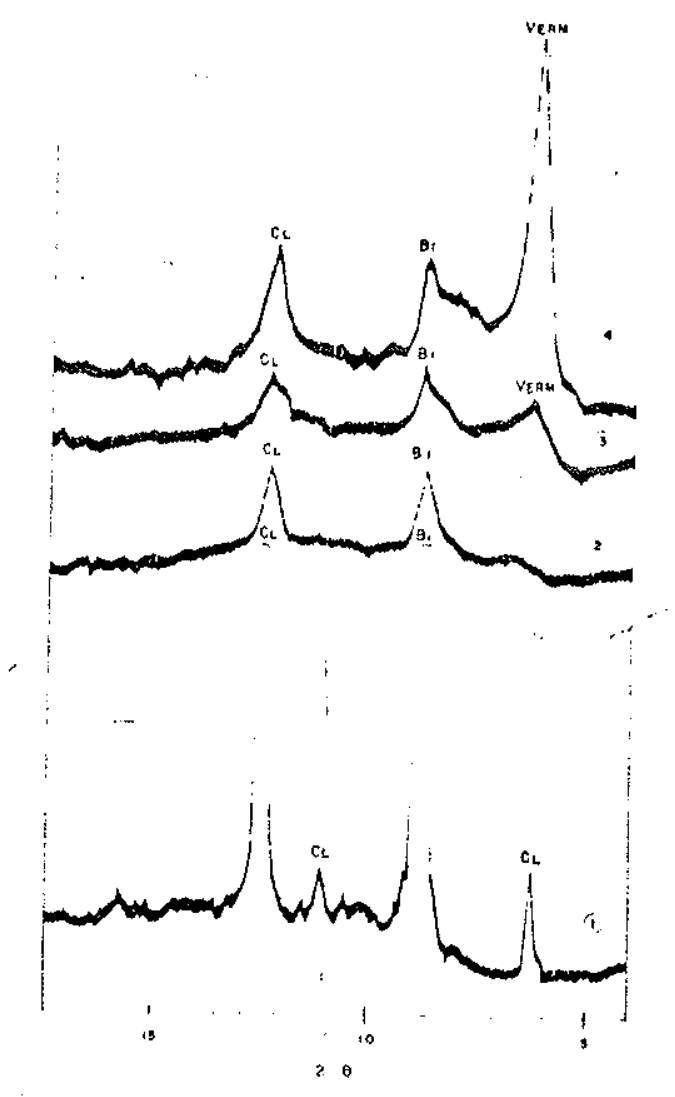

Fig. 43 - Difratogramas do material micáceo em diferentes estádios de alterą̧ão: 1 - rocha fresca; 2 - rocha parcialmente decomposta; 3 - saibro, rocha totalmente decomposta e 4 - transiçäo rocha decompos ta-solo.

A separação do material micáceo ao longo do perfil 
sua análise microscóplca e aos $\mathrm{x}$ aios $\mathrm{X}$, fornoceram as oucessivas etapas da alteração da biotita (Fig. 43). A sequêncla biotita $\longrightarrow$ hidrobiotita _- vermiculita _._ caulinita ou gibbsita (somente constatada ao microscópio), aqui observada, coincide parcialmente com a sequência de formação de minerais de alteração estabele cida por Jackson, et al. (1952), para os foliossilicatos: mica $\longrightarrow$ ilita $\longrightarrow$ mica intermediária $\longrightarrow$ vermiculita $\longrightarrow$ montmorilonita $\rightarrow$ caulinita $\longrightarrow$ gibbsita; e ainda com a sequência oboexvada por Walker (1949) que, estudando a alteração de biotitas no solo, che gou a determinar vários estádios intermediários entre biotita e vermiculita.

\section{C - Comportamento geoquímico dos elementos}

Com base nos dados químicos e nos cálculos isovolumétricos, pudemos estabelecer o balanço geoquímico dos elementos principais nos perfis estudados.

Comportamento do Bilício

O comportamento do silício no perfil IT-2, que represen ta a alteração em condições de má drenagem, é bem diferente dos demais, que representam condições de drenagem boa ou moderada

No perfil IT-2 a eliminação da sillica é relativamente reg trita, não atingindo 15\%. Tôda a sílica colocada em solução origi nou-se da alteração dos feldspatos, pois o quartzo não apresenta si nal algum do ataque do intemperismo. Grande parte desta sílica permanece no perfil, recombinando-se com o alumínio, para for mar caulinita; e apenas uma pequena parte é lixiviada do perfil. 
Nos perfis IT-1 e MO-l, a saf́la de silica é bem mais efetiva, atingindo cêrca de $40 \%$ nos estádios iniciais, que corres pondem ao saibro; e aursenca z'àpidamente nos horizontes do so 10, onde a eliminação da súlica pode alcançar $85 \%$.

Comportamento do alumínio

O comportamento do alumínio nos perfis estudados evidenciam que êste elcmento apresenta pequena mobilidade. Prà ticamente todo o al umínio colocado em solução, a paxtir da alte ração de feldspatos e de biotita, permanece noperfil ou recombinado com silica formando a caulinita, ou precipitado na forma de hidróxido de alumínio (gibbsita).

No perfil IT-1 o alumínio apresenta um balanço ligeira mente positivo ao longo de todo o perfil, não atingindo valores a periores a $6 \%$.

No perfil IT-2 o balanço continua sendo positivo, ' porém de maneira bern mais acentuada que no perfil antexior, atin gindo um aumento de cêrca de $30 \%$. A primeira vista, poderia pa recer estranho o fato de haver entrada de alumínio em um perfil onde o único mineral secundário estável é a caulinita; entretanto, a eliminação de sílica é de tal maneira baixa, que há constante mente no perfil, súlica $\mathrm{cm}$ excesso para formax caulinita.

No perfil $\mathrm{NiO}-1$ o balanço de alumínio apresenta sempre valores negativos, em todos os estádios de alteração.

Em todos êsses perfis o balanço do alumínio, nos hori zontes superiores, era mais negativo ou menos positivo, conforme o perfil. Este fato deve estar certamente ligado à presença de matéria orgânica, que permite a dissolução da gibbsita e pro- 
voca a eliminação do alumínio.

\section{Comportamento do ferro}

O ferro sofre um enriquecimento ao longo de todo o perfil IT-1, pois as condições de boa drenagenı pernitem sua oxidação para o estado oxidado $\mathrm{Fe}^{3+}$, que é o íon com pequena mobilidade.

No perfil $\mathrm{NO}-1$ o ferro apresenta um balaņ̧o positivo nos primeiros estádios de alteraçãoe, posteriormente, no solo, um balanço negativo.

Já no perfil IT-2, o comportamento do ferro é bem diferente do apresentado nos perfis anteriores, pois aqui êle é eliminado cada vez mais intensamente, com a evolução do intemperismo. A ausência de ambiente oxidante no perfil IT-2 não permi te a oxidação do ferro para $\mathrm{Fe}^{3+}$, fazendo com que êste se man tenha no estado reduzido. O ́́on $\mathrm{Fe}^{2+}$, nas condições normais em que se desenvolve o intemperismo, é bastante solúvel, sendo par cialmente eliminado do perfil. Sòmente em condições de $\mathrm{pH}$ anox mais para o solo, é que o ́́n $\mathrm{Fe}^{2+}$ pode precipitar-se na forma de hidróxido (Fig. 44).

Portanto, as condições de drenagem defeituosa facili tam a colocação do ferro em solução e também a sua eliminação do perfil. Rich et Obenshain (citados por Segalen, 1964) mostra $x$ am que solos derivados da mesma rocha possuiam teores diferen tes em ferro livre, conforme as condiçōes de drenagem:

$\begin{array}{llcc}\text { Drenagem } & \text { boa } & \text { regular } & \text { defeituosa } \\ \mathrm{Fe}_{2} \mathrm{O}_{3} \% & 0,86 & 0,40 & 0,04\end{array}$



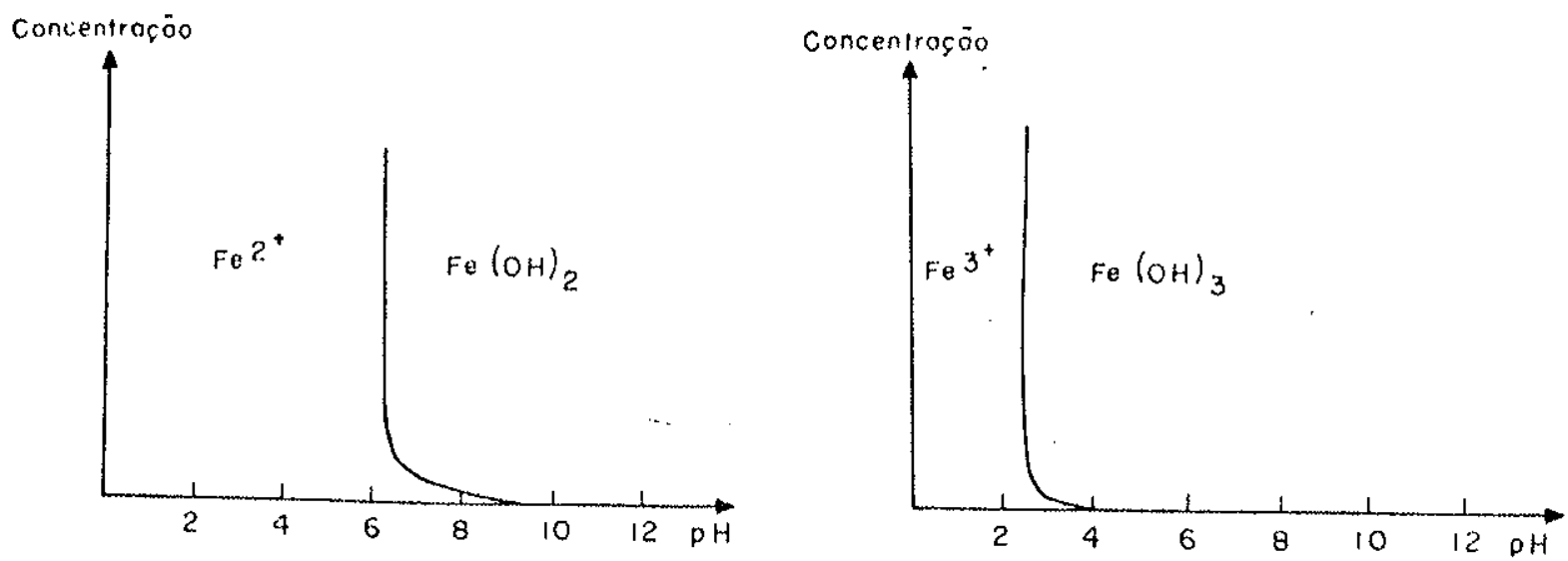

Fig. 44 - Diagrama de precipitação de hidróxido ferroso e hidróxido férrico a partir do ín ferroso e férrico.

Comportamento dos alcalinos e alcalinos terrobos

O sódio e o potássio säo lixiviados do pexfil IT-1, de maneira lenta e progressiva nos primeiros estádios de alteração; lixiviação esta, que aumenta ràpidamente com a evolução do pxocesso intempérico. No horizonte IT-13a, que corresponde z̀ transição saibro-solo, pràticamente todo o sódio e cêrca de $70 \%$ do potás sio são eliminados.

O cálcio é eliminado do perfil de maneira completa desde os estádios iniciais de alteração, com exceção do perfil IT-2 (mal drenado) cuja eliminação está por volta de $60 \%$.

De todos os alcalinos e alcalinos terrosos o magnésio é o que apresenta menor mobilidade, não se movimentando nos primeiros estádios de alteração no perfil $1 \mathrm{~T}-1$, apresentando uma eliminação de $45 \%$ no perfil $\mathrm{NiO}-1$ e cêrca de $50 \%$ no perfil IT-2. Em nenhum dos três casos sua eliminação chega a ser total, pois parte do magnésio colocado em solução pode ficar retido no perfil, já que êste elemento forma minerais secundários, como por exemplo, vermiculita e 
clorita.

O sódio e o édclo, provenientes da alteração de pla gioclásios, em todos os pexfis são colocados em solução desde as primeiras etapas de intemperismo. Em razão de serem difícilmente incorporados às argilas são ràpidamente eliminados, podendo êste fato ser relacionado aos baixos valores de seus po tenciais iônicos.

O potássio apresenta eliminação mais moderada, sobretudo por causa da grande resistência oferecida pelos feldspa tos potássicos à ação dọ intemperismo, acrescido ainda de seu grande poder de adsorção. 
ESTUDO DO INTEMPERISN O SOBRE OS DIABASIOS E A FOR MAÇAO DOS PERFÝS DE A.LITERAÇAO

O estudo da ação do intemperismo sôbre os dizbásios da região foi realizado em 6 perfis de alteração, quatro dos quais desenvolvidos em condições de drenagem moderada ou boa, e dois, sob condições de hidromorfia.

Em virtude da posição topográfica que os perfis mal drẹnados ocupam no terreno, não conseguimos coletar tôda a sequência de alteração, pois os horizontes superiores apresentam uma intensa contribuição de material estranho ao perfil, o que faz perderem totalmente as características herdadas da rocha original.

Os perfis CA-l e PA-1, escolhidos para representar a alteração de diabásios sob condições de drenagem moderada, a pesar de se desenvolverem a partir de rochas ligeiramente diferentes, apresentam resultados mineralógicos e químicos seme lhantes. Em virtude dêste fato, a evolução mineralógica dos hori zontes dos perfis de alteração seŕá descrita apenas para o CA-1.

$$
1 \text { - Perfil CA - } 1
$$

\section{A - Análise granulométxica}

A análise da tabela 12 e da figura 45 evidencia que a passagem da rocha mãe para o solo se manifesta por um decrésci mo no teor das frações grosseiras.

O teor em argila, que no material oxiginal decomposto 
TABELA 12

Composição granulométrica do perfil CA-1

TERRA FINA SECA AO AR

\begin{tabular}{|c|c|c|c|c|c|c|}
\hline Horizonte & $\begin{array}{l}\text { Profundidacle } \\
\mathrm{em} \mathrm{cm}\end{array}$ & $\begin{array}{l}\text { Areia } \\
\text { Grossa }\end{array}$ & $\begin{array}{c}\text { Areia } \\
\text { Fina } \\
\%\end{array}$ & $\underset{\%}{\operatorname{Limo}}$ & $\underset{\%}{\operatorname{Argila}}$ & $\begin{array}{c}\text { Classe } \\
\text { textural }\end{array}$ \\
\hline$A_{11}$ & $0-5$ & 13,0 & 29,1 & 17,5 & 40,4 & Argilosa \\
\hline$A_{12}$ & $5-12$ & 13,7 & 28,6 & 17,2 & 40,5 & Argilosa \\
\hline$B_{1}$ & $12-40$ & 9,4 & 22,5 & 13,6 & 54,5 & Argilosa \\
\hline $\mathrm{B}_{2}$ & $40-75$ & 7,9 & 20,9 & 12,6 & 58,6 & Argilosa \\
\hline $\mathrm{B}_{3}$ & $75-245$ & 10,0 & 23,0 & 19,1 & 47,9 & Argilosa \\
\hline $\mathrm{C}_{1}$ & $245-382$ & 6,7 & 25,7 & 33,1 & 34,6 & $\begin{array}{l}\text { Limo } \\
\text { ergiloso }\end{array}$ \\
\hline $\mathrm{C}_{2}$ & $382-504$ & 6,0 & 28,7 & 39,7 & 25,6 & $\begin{array}{l}\text { Limo } \\
\text { argiloso }\end{array}$ \\
\hline $\mathrm{c}_{3}$ & $504-586$ & 7,0 & $41,8$. & 41,3 & 9.9 & $\begin{array}{l}\text { Fino } \\
\text { arenoso }\end{array}$ \\
\hline$D_{1}$ & $586-806$ & 42,0 & 35,9 & 21,2 & 0,9 & $\begin{array}{l}\text { Fino } \\
\text { arenoso }\end{array}$ \\
\hline
\end{tabular}

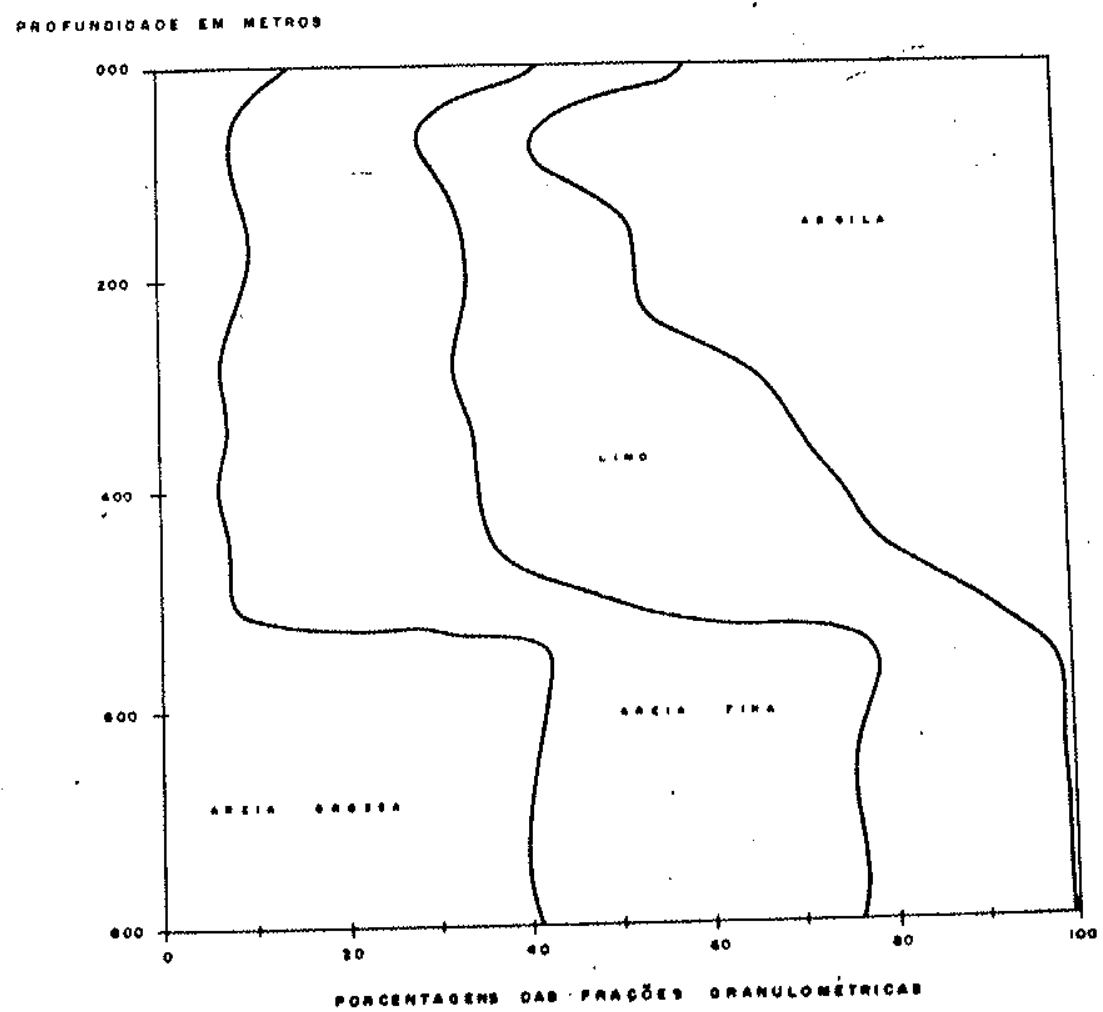

Fig. 45 - Distribuição das frações granulométricas ao longo do perfil CA-1. 
é inferior a $5 \%$, atinge nos horizontes superiores teores por vêzes superiores a $50 \%$.

As fraçöss areî, que constituem cêrca de $70 \%$ nas pri meiras etapas de aiteraçäo, apresentam um decréscimo conside rável com a evolução do intcmperismo, possuindo nos nívsis superficiais teores menores que $40 \%$.

\section{B - Análise miner alógica do perfil}

\section{CA- 17}

Rocha fresca. Diabásio cinza escuro apresentando tura sub-ofítica. Sua composição mineralógica, determinada por microscopia óptica é a seguinte expressa em \% (volume).

$\begin{array}{lr}\text { Plagloclásios } & -52 \\ \text { Plroxênios } & -35 \\ \text { Olivina (alterada) } & -3 \\ \text { Acessórios } & -9 \\ \text { Mesostasis } & -1\end{array}$

Os plagioclásios, principais constituintes da rocha, a presentam composição que varia de $\mathrm{Ab}_{35} \mathrm{An}_{65}$ a $\mathrm{Ab}_{45} \mathrm{An}_{55^{\circ}}$. Co mumente são zonados. Apresentam-se sob a forma de ripas cujo comprimento varia entre 0,3 e $0,9 \mathrm{~mm}$, mostrando frequente geminação segundo as leis da albita, periclínio e Carlsbad.

Os piroxênios apresentam dois tipos de clinopiroxê nio: augita, predominante, e pigeonita, subordinada. Ambos os tipos formam cristais comumente idiomorfos, equigranulares. cujos tamanhos médios estäo por volta de $0,8 \mathrm{~mm}$.

A olivina apresenta-se totalmente alterada em um mi- 
neral do grupo das montmorilonitas, provàvelmente nontronita, que aubstitui pseudomòrficamente a ollivina. Pogsui coloração verde-amarelada e apresenta-se pouco anisótropa.

Entre os acessórios, os principals são: magnetita e 11nenita. Formam cristais subidiomorfos ou xenomorfos, A a patita, outro mineral acessório, ocorre na forma de pequenas a gulhas dispostas irregularmente na mesóstasis, a qual forma uma massa intersticial constituŕda por quartzo e feldspato potás sico.

\section{$C A-16$}

Rocha parcialmente decomposta, representando o es. tádio inicial da alteração intempérica. O diabásio torna-se mais claro que o do nível anterior e constitui uma crosta de $1 \mathrm{~cm}$ de espessura, que envolve a rocha fresca.

Os plagioclásios, parcialmente alterados, aprésentam um alargamento de suas clivagens e fissuras, que são preenchidas por um material incolor, isótropo, interpretado como gel amorfo (Fig. 46). As vêzes, no meio dêste material amorfo, pro duto primeiro da decomposição dos plagioclásios, notam-se crig talitos, identificados como gibbsita.

O piroxênio evidencia uma resistência ao intemperis mo ligeiramente superior ao plagioclásio. Suas clivagens, pre enchidas por hidróxido de ferro, formam um quadriculado den so, cujos núcleos se apresentam ainda frescos (Fig. 47). Obser ve-se que a presença da goethita já é notada neste horizonte. E possível que parte do piroxênio se tenha transforma do em montmorilonita, o que se verifica pelo aumento de teor da 


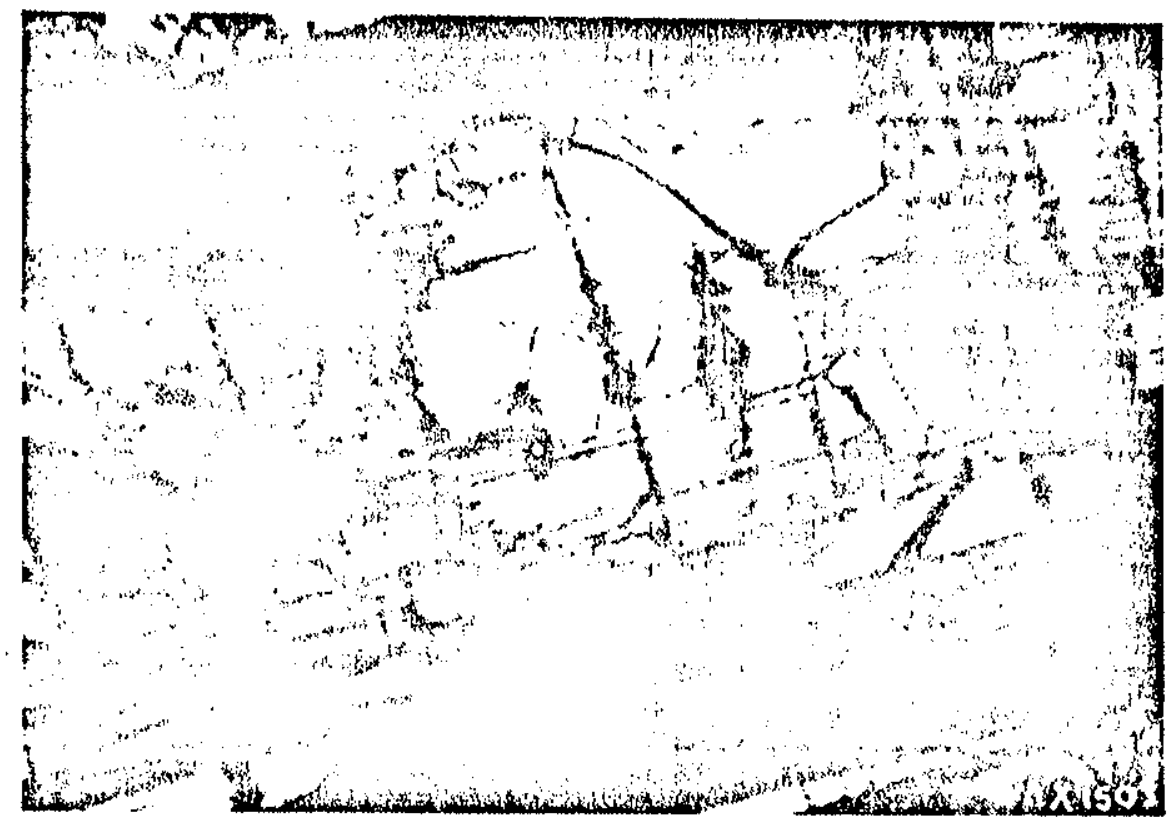

Fìg. 46 - Início da alteração do diabásio - plagioclá sio se alterando para gels amorfos. Estes gels se desenvolvem ao longo das fissurase clivagens do cristal.

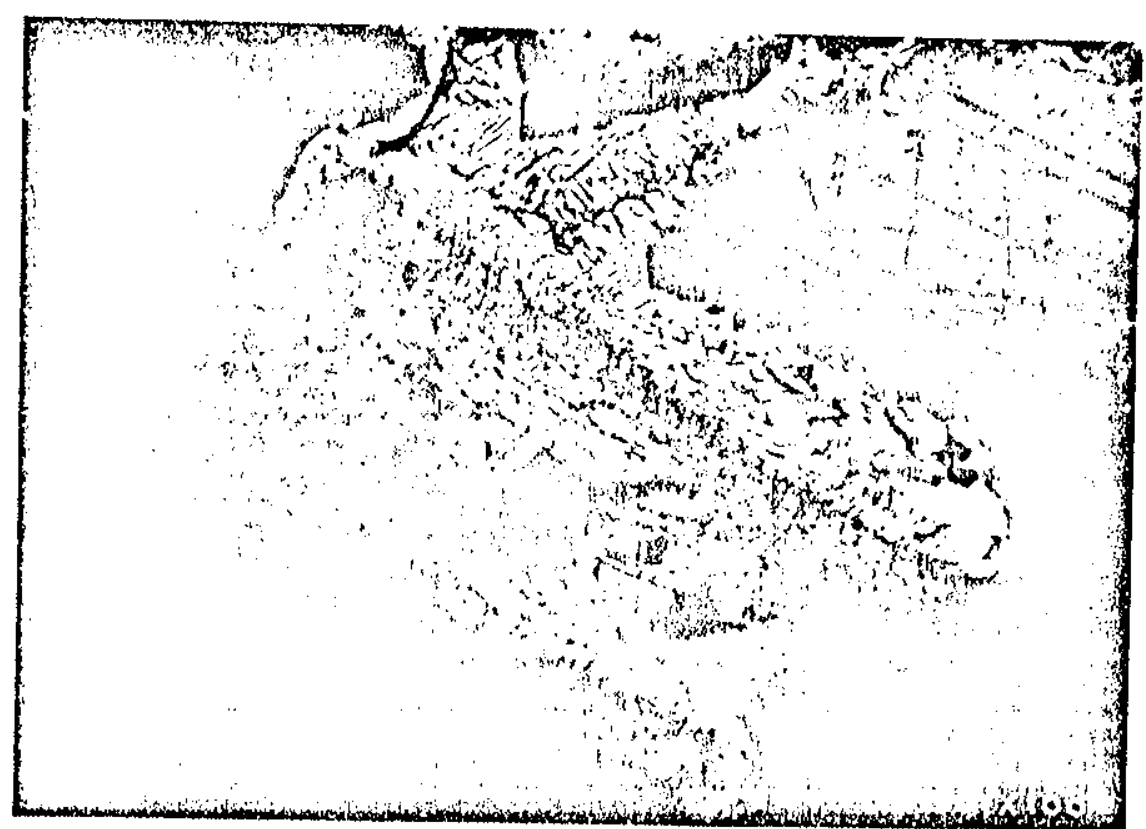

Fig. 47 - Alteração do plagioclásio em gibbsita. Estádio de alteração mais avançado, onde os crig tais de plagioclásio são transformados $\mathrm{em}^{-}$ gibbsita, bem cristalizada. 
mesma neste nível de alteração; apesar de não têrmos nenhuma evidência direta de tal transforną̧ão.

Neste cotidio tcruon Lima grande quantidade de mate rial amorfo, formado tisto a partir dos plagioclásios, quanto do piroxênios, o que pode ser constatado da análise das curvas térmicas diferenciai s apresentadas na figura 48 .

Os minerais acessórios, bem como o quartzo, apre sentam pequena concentrą̧ão residual, em virtude de sua alta resistência à ação do intempericroo.

\section{$\mathrm{CA}-15$}

Rocha decomposta, formando uma capa concêntrica que envolve os dois níveis anteriores. Possui espessura máxi ma de $4 \mathrm{~cm}$, apresentando-se avermelhada e com consigtência bastante friável.

Apresenta uma evolução mineralógica bastante semelhante ao estádio antcrior. A presença de material amorfo, ain da continua abundante (Fig. 48 ).

Os plagioclásios e piroxênios apresentam decréscimo acentuado em seus teores, tendo sido alterados para gibbsita e goethita, respectivamente, além do material amorfo já citado.

A caulinita começa a cristalizar-se neste estádio, en quanto que a montmorilonita sofre uma diminuiçäo de teor insigg nificante.

A presença de opala foi notada nos estudos de micros copia óptica. 


\section{$\mathrm{CA}-14$}

Rocha totalmente decomposta, notando-se ainda a textura do material original.

Neste nível de altcração, os principais minerais forma dores da rocha desaparecem do perfil, dando lugar ao apareci mento de grande quantidade de gibbsita, caulinita e goethita, ao lado de certa quantidade de material amorfo.

A gibbsita, que é o principal mineral dêste horizonte , pràticamente não ocorre nas fraçōes finas (Figs. 49, 50 e 51), 11 mitando-se às mais grosseiras, onde aparece substituindo os pla gioclásios.

O teor de montmorilonita apresenta considerável decrés cimo, concentrando- be na fração argila (Fig. 51). A sua separa ção granulométrica em duas subfrações (uma maior que 0,2 e ou tra menor) por meio de centrífuga, conforme técnica preconizada por Jackson (1965), mostrou que a montmoxilonita se concentrou na parte mais fina.

O quartzo, juntamente com os minerais acessórios, mantém seu teor pràticamente constante, mostrando ligeiro au mento em direção à superfície.

Opala e halloysita for am observadas neste estádio de cle composição, sendo a última sòmente notada na análise do mate rial por microscopia eletrônica (Fig. 52).

\section{CA -13}

Rocha totalmente decomposta, como no caso anterior. não sendo notada, porém sua textura original. 


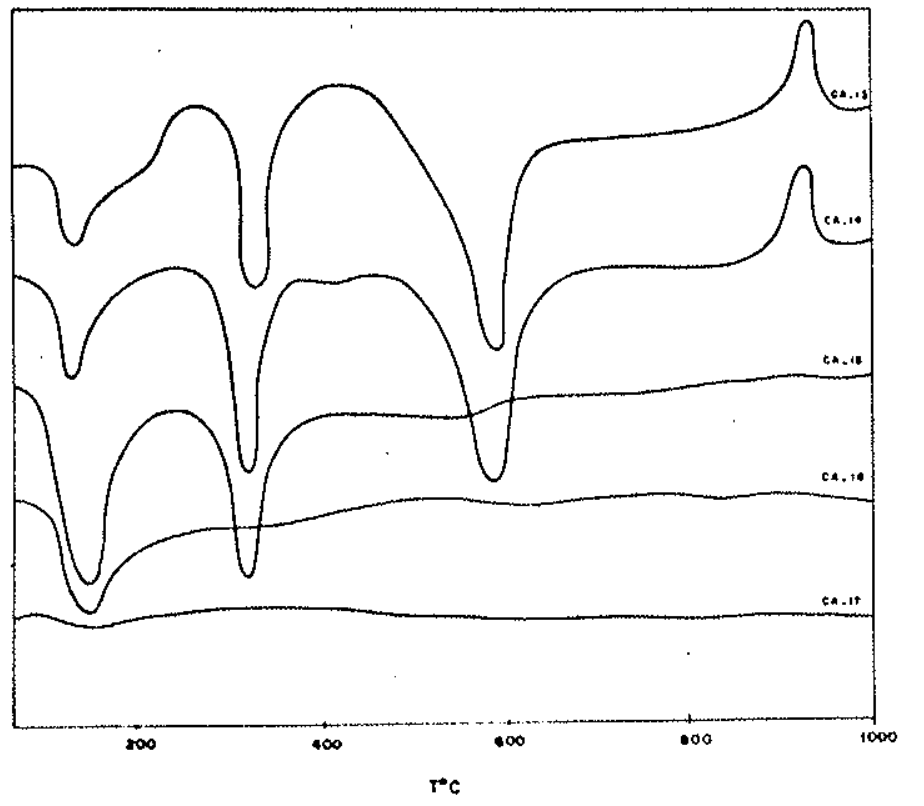

Fig.48 - Termogramas da fração argila dos diferen tes níveis do perfil CA-1. Nota-se nos primeiros estádios a predominância de gibbsi ta(pico endotérmico ao redor de $300^{\circ} \mathrm{C}$ ) posteriormente a de caulinita (pico endotérmico ao redor de $600^{\circ} \mathrm{C}$ ). A amplitude anormal do pice endotérmico a $105-125^{\circ} \mathrm{C}$ deve provavelmente estar correlacionada com a existência de quantidades apreciáveis de matexial amorfo.

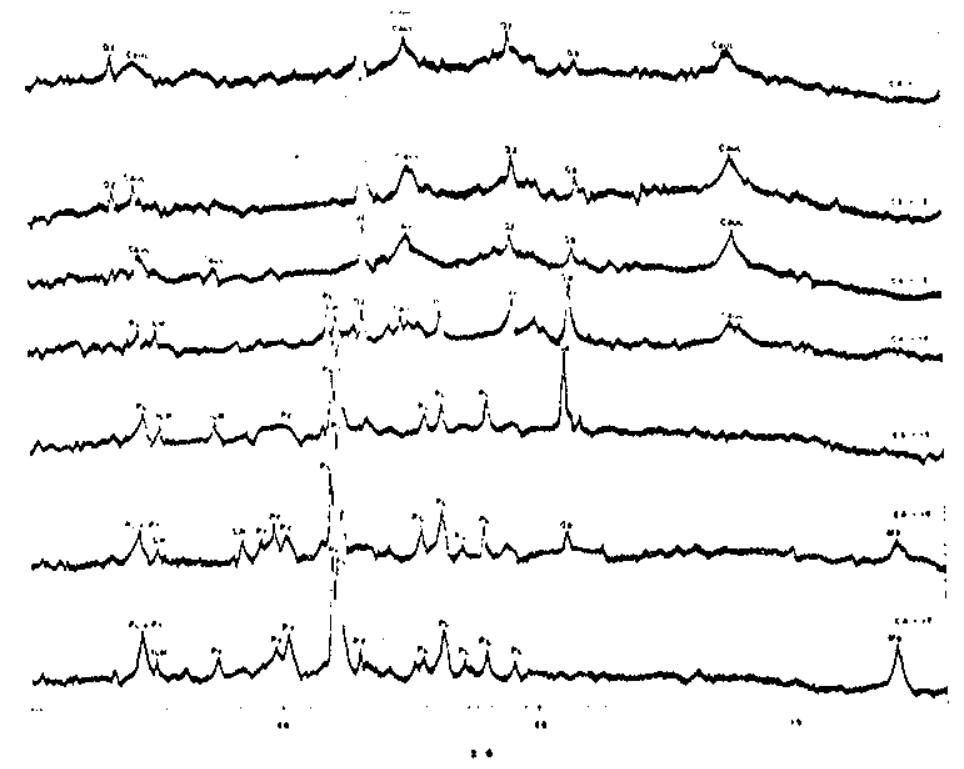

Fig. 49 - Difratogramas dos diferentes horizontes de alteração do perfil CA-1, Qz (quartzo). Pl(plagioclásio), Py(piroxênios), ILM(ilme nita), No(montmorilonita), CAUL(caulinita) $\in G B$ (gibbsita). 


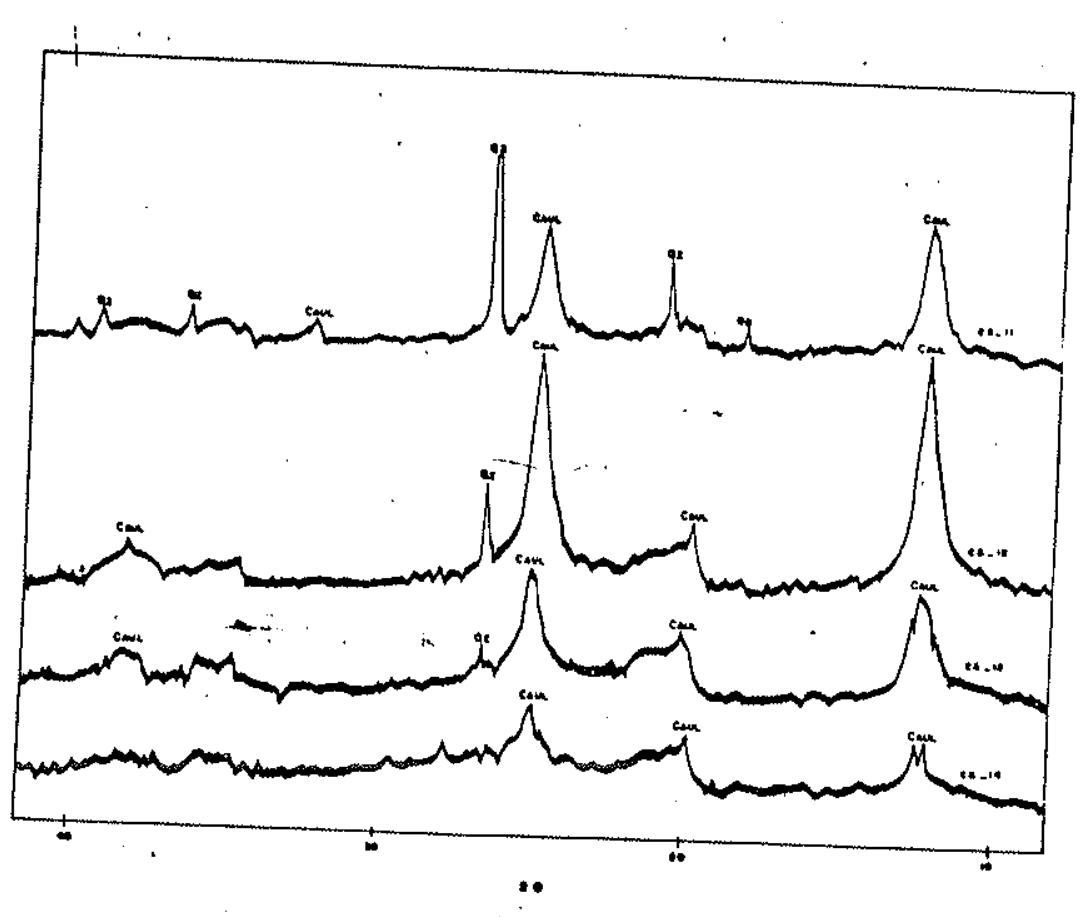

Fig.50 - Difratograma da fraçäo limo $(0,02-0,002$ $\mathrm{mm}$ ) dos diferentes níveis de aiteração do
perfil CA-1.

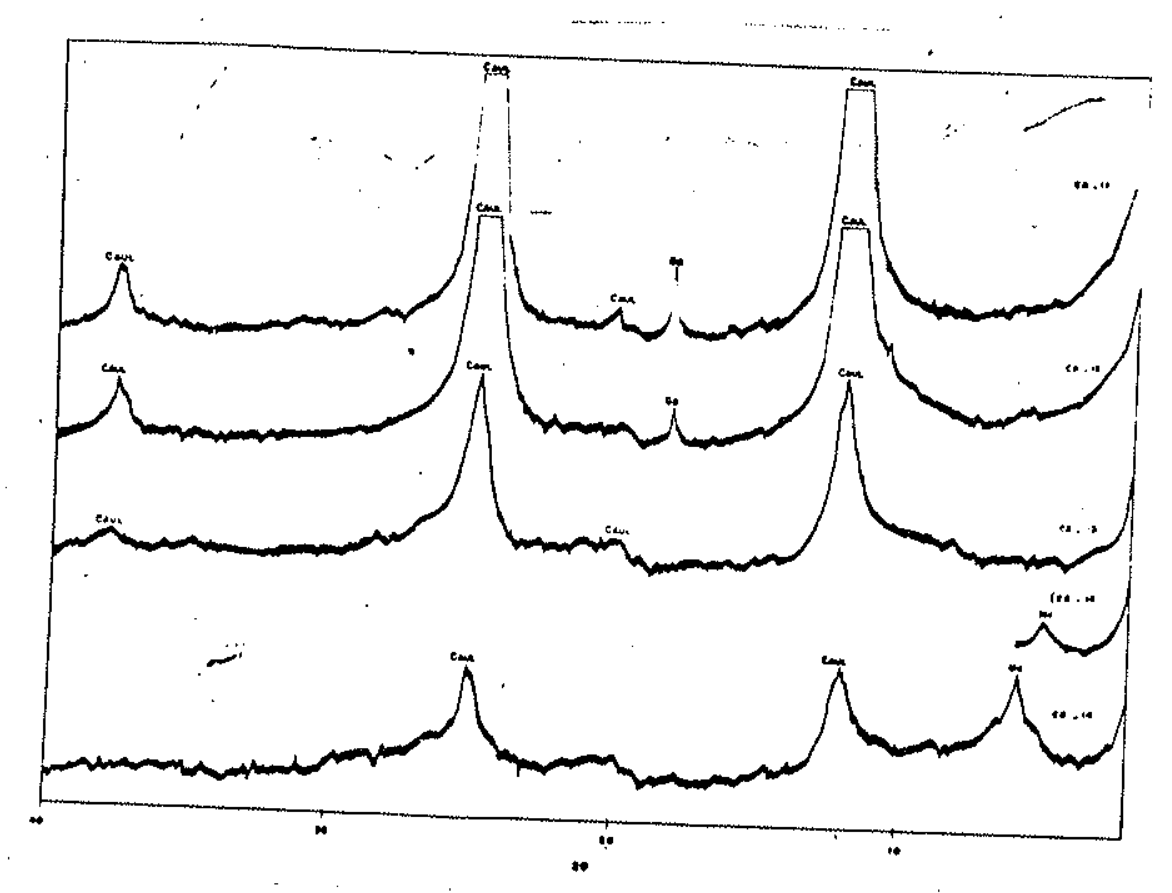

Fig. 51 - Difratogramas da fração argila (menor que $0,002 \mathrm{~mm}$ ) dos diferentes níveis de alteração do perfil CA-1. A amostra $(\mathrm{CA}-14)$ foi tratada com etilenoglicol. 


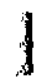

1

1

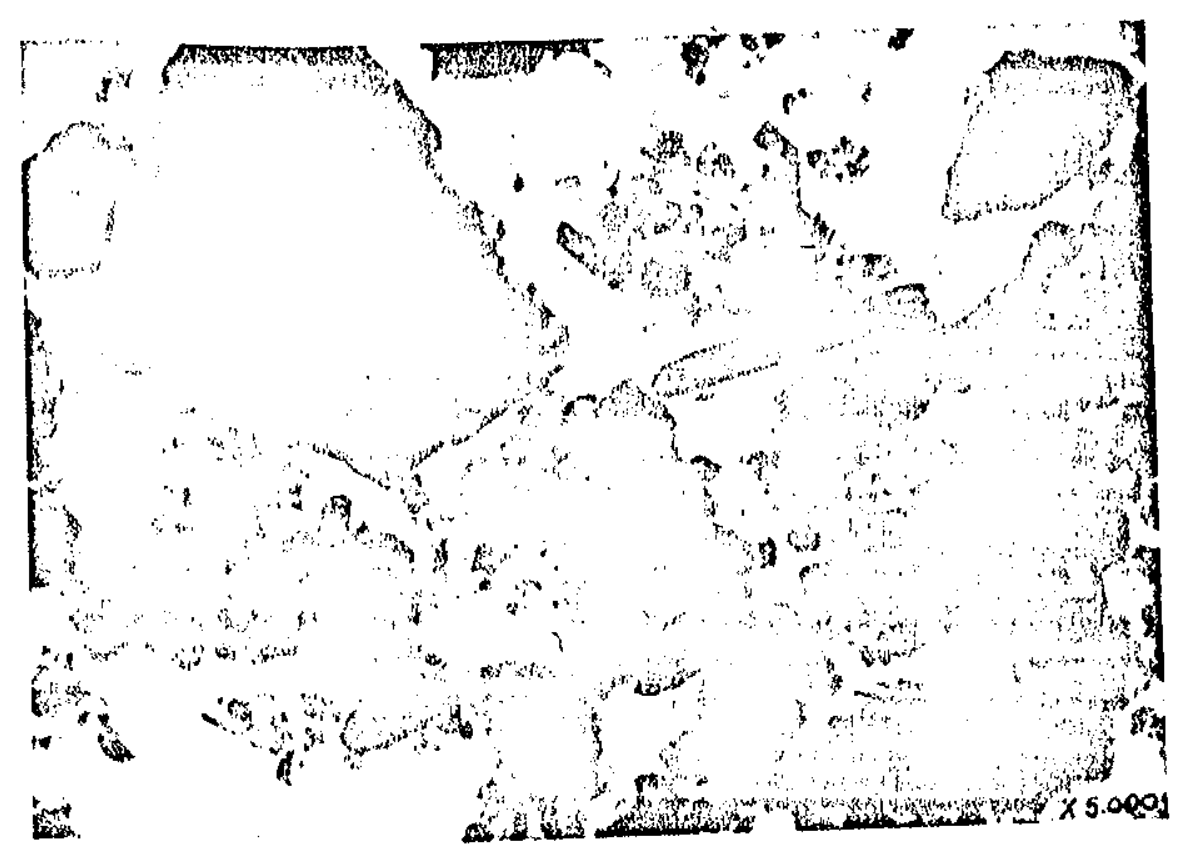

Fig. 52 - Nicrografia eletrônica da fração argila do horizonte CA-l4. Grandes cristais de caulinita associados a tubos longes o curtos de halloysita. 
Este nível de alteração é caracterizado por uma dimi nuição pronunciada no teor de gibbsita, associada a um aumen to procminente do teor de caulinita, que chega a constituir mais de $50 \%$ do material.

O quartzo tem seu teor aumeniado de maneira acen tuada. E possível que parte dêste quartzo seja produto de contaminação do perfil por material alógeno, pois os grãos dêsse mi neral evidenciam certo arredondamento.

Os acessórios mantêm seus teores constantes. A mag netita e a ilmenita são bastante estáveis nas condiçōes superfi ciais de alterạ̄on, entretanto, alguns cristais apresentam suas bordas transformadas em goethita:

A opala continua presente neste estádio de intemperis mo. A halloysita foi detectada por intermédio da microscopia eletrônica.

Não se observou a montmorilonita neste estádio de alteração, em nenhuma das frações analisadas.

A quantidade de material amorfo é, neste horizonte. bastante reduzida em relação aos anteriores (Fig. 48).

\section{$\dot{C} A-12$}

Trata-se de um horizonte pedológico $B$.

A caulinita mantém-se constante, constituindo mais de $50 \%$ do material.

Mineralògicamente, êste nível é bastante semelhante ao anterior, tanto qualitativa como quantitativamente.

Os difratogramas (Fig. 51) mostram que a fração argi la é constituída, pràticamente, só por caulinita, com quantida - 
des subordinadas de quartzo e gibbsita.

Opala e halloysita foram detectadas em algumas amos tras estudadas.

$$
\text { CA }-11
$$

E o horizonte superficial do perfil de alteração. Apresenta uma alta porcentagem de contaminação por material estra nho ao perfil, principalmente quartzo, que atinge neste horizonte um teor bastante alto.

A caulinita sofre um decréscimo em seu teor, omesmo acontecendo com a gibbsita. Este mineral, neste nível de alteração, apxesenta-se concentrado nas frações finas, argila e $\underline{\text { li }}$ mo.

A Tabela 13 e a figura 53 representam os dados mineralógicos quantitativos do pexfil $\mathrm{CA}-1$.

\section{C - Análises Químicas}

Os dados referentes ìs análises químicas e os cálcu los isovolumétricos dos diferentes níveis de alteração do perfil CA-1 são apresentados na tabela 14 .

$$
2 \text { - Perfil PA - } 1
$$

\section{A - Análise granulométrica}

Como no perfil CA-1, a passagem da rocha para o solo é caracterizada por um progressivo aumento das frações fi nas (Tabela 15 e Fig. 54). 
TABELA 13

Composição Niineralógica dos diferentes níveis de alteração do perfil CA-1 em $\%$ (volume)

\section{CA-17 CA-16 CA-15 CA-14 CA-13 CA-12 CA-11}

\begin{tabular}{|c|c|c|c|c|c|c|c|}
\hline Plagioclásios & 51 & 36 & 14 & $\therefore$ & - & - & - \\
\hline Piroxênios & 35 & 23 & 16 & - & - & - & - \\
\hline Olivina & 8 & - & - & - & - & - & - \\
\hline Acessórios & 5 & 12 & 16 & 15 & 18 & 13 & 16 \\
\hline Quartzo & $t r$ & 5 & 6 & 8 & 13 & 14 & 25 \\
\hline Gibbsita & - & 11 & 25 & 35 & 12 & 11 & 9 \\
\hline Montmorilonita & - & 7 & .5 & 4 & - & 5 & - \\
\hline Caulinita & - & - & 8 & 22 & 52 & 50 & 40 \\
\hline Goethita & - & 6 & 10 & 16 & 15 & 12 & 10 \\
\hline Halloysita & - & - & - & tr. & $t r$ & tr. & - \\
\hline Opala & - & - & tr & $t x$. & tr. & tr. & - \\
\hline
\end{tabular}

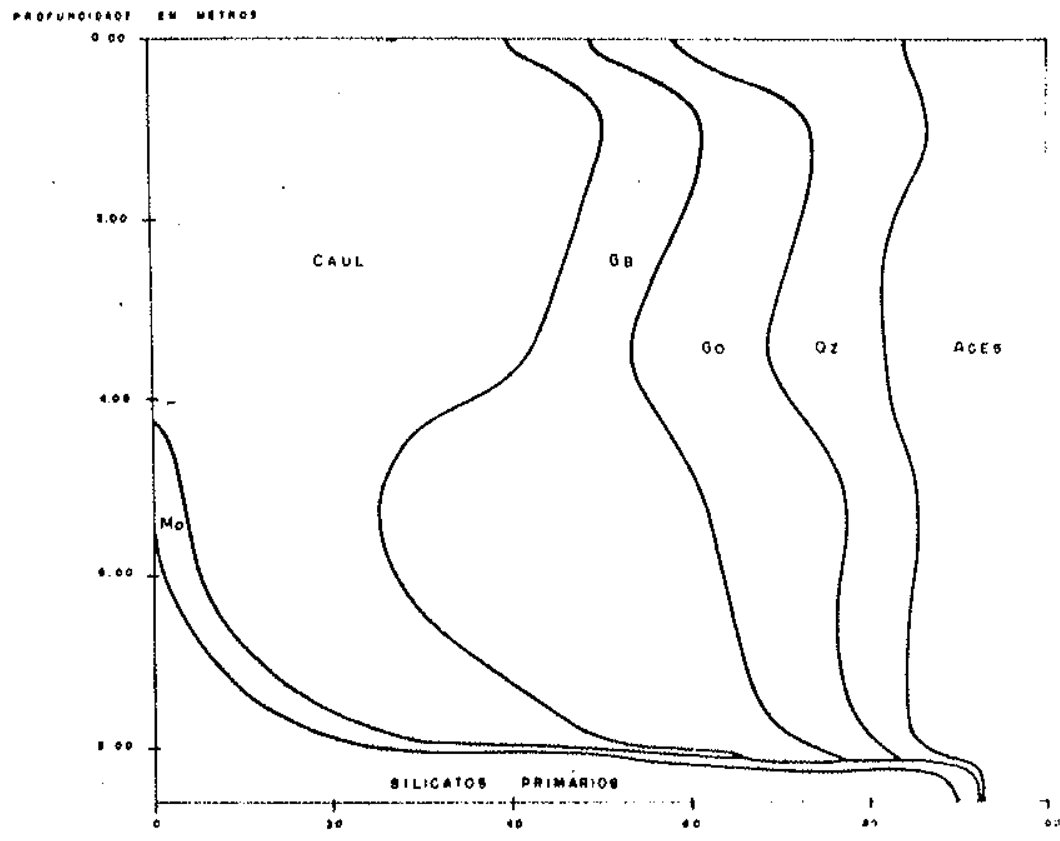

COMPOSIEÁ⿴囗十 $1 \% 1$

Fig. 53 - Esquema mineralógico do perfil $\mathrm{CA}_{2}-1$ 
TABELA 14

Análises químicas totais do perfil $\mathrm{C} / \mathrm{A}-\mathrm{L}$ (porcentagem pêso) e porcentagens a volume constante culculadas a partir das análises químicas

\begin{tabular}{|c|c|c|c|c|c|c|c|}
\hline $\mathrm{SiO}_{2}$ & $\begin{array}{c}C A-17 \\
27,00\end{array}$ & $\begin{array}{c}C A_{2}-16 \\
4 x, 20\end{array}$ & $\begin{array}{c}C A-15 \\
27,60\end{array}$ & $\begin{array}{c}C F_{2}-1 \% \\
19,60\end{array}$ & $\begin{array}{c}C A-13 \\
32,60\end{array}$ & $\begin{array}{c}C A-12 \\
33,20\end{array}$ & $\begin{array}{c}C A-11 \\
36,80\end{array}$ \\
\hline $\mathrm{Al}_{2} \mathrm{O}_{3}$ & 14,80 & 15,10 & 24,60 & 28,80 & 21,40 & 23,40 & 20,60 \\
\hline $\mathrm{Fe}_{2} \mathrm{O}_{3}$ & 1,71 & 13,50 & 21,80 & 24,00 & 20,60 & 18,60 & 16,80 \\
\hline $\mathrm{FeO}$ & 13,21 & 5,60 & 3,40 & 2,58 & 2,72 & 2,72 & 4,30 \\
\hline $\mathrm{K}_{2} \mathrm{O}$ & 0.78 & 0,70 & 0,16 & 0,93 & 0,24 & 0,15 & 0,15 \\
\hline $\mathrm{Na}_{2} \mathrm{O}$ & 2,24 & 1,40 & 0,14 & 0,10 & 0,11 & $\operatorname{tr}$. & $t r$. \\
\hline $\mathrm{MgO}$ & 5,30 & 4,10 & 2.07 & 1,40 & 0,70 & 0,40 & 0,70 \\
\hline $\mathrm{MinO}$ & 0,10 & 0,20 & 0,03 & 0,15 & 0,16 & 0,17 & 0,17 \\
\hline $\mathrm{CaO}$ & 10,40 & 7,20 & 2,64 & 0,70 & 0,67 & 0.67 & 0,78 \\
\hline $\mathrm{TiO}_{2}$ & 3,80 & 3,10 & 5,20 & 4,00 & 5,00 & 5,00 & 5,00 \\
\hline $\mathrm{P}_{2} \mathrm{O}_{5}$ & 0,30 & 0,50 & 0,80 & 0,20 & 0,40 & $t r$ & tr. \\
\hline $\mathrm{H}_{2} \mathrm{O}-$ & 0,35 & 2,00 & 4,50 & 5.90 & 3.20 & 2,30 & 1.40 \\
\hline $\mathrm{H}_{2} \mathrm{O}^{+}$ & - & 2,50 & 7,10 & 11,50 & 10,40 & $12 ; 00$ & 12,50 \\
\hline Total & 99,99 & 100,10 & 100,04 & 99,86 & 98,22 & 98,61 & 99,20 \\
\hline Dens, apar. & 3,08 & 2,86 & 1,70 & 1,61 & 1,12 & 1,24 & 1,34 \\
\hline Quartzo & - & 4,3 & 4,9 & 6,6 & 9,7 & 12,2 & 19,9 \\
\hline $\mathrm{SiO}_{2}$ & & $-18,0$ & $-69,0$ & -85.5 & $-82,3$ & & \\
\hline $\mathrm{Al}_{2} \mathrm{O}_{3}$ & & $-5,3$ & $+2,4$ & $+1,8$ & $-47,2$ & & \\
\hline Fe total & & $+17,9$ & $+3,5$ & $+7,6$ & $-43,6$ & & \\
\hline $\mathrm{K}_{2} \mathrm{O}$ & & $-16,7$ & $-87,5$ & $-41,7$ & $-87,5$ & & \\
\hline $\mathrm{Na}_{2} \mathrm{O}$ & & $-42,0$ & $-95,7$ & $-97,1$ & $-98,6$ & & \\
\hline $1 \mathrm{gC}$ & & $-28,2$ & $-76,1$ & $-85,9$ & $-95,1$ & & \\
\hline 20 & & $-35,6$ & $-8 x, 4$ & $-96,6$ & $-97,8$ & & \\
\hline $\mathrm{H}_{2} \mathrm{O}$ total & & +1763 & +2580 & +3409 & +2272 & & \\
\hline
\end{tabular}


TABELA 15

Composição granulométrica do perfil PA-1

\begin{tabular}{|c|c|c|c|c|c|c|c|}
\hline \multirow[b]{2}{*}{ Horizonte } & \multirow{2}{*}{\multicolumn{2}{|c|}{$\begin{array}{l}\text { Profundidade } \\
\mathrm{cm} \mathrm{cm}\end{array}$}} & \multicolumn{4}{|c|}{ TERRA FINA SECA AO AR } & \multirow[b]{2}{*}{$\begin{array}{l}\text { Classe } \\
\text { textural }\end{array}$} \\
\hline & & & $\begin{array}{c}\text { Areia } \\
\text { Grossa } \\
\%\end{array}$ & $\begin{array}{c}\text { Areia } \\
\text { Eina } \\
\%\end{array}$ & $\underset{\%}{\operatorname{Limo}}$ & $\begin{array}{l}\text { Aurgila } \\
\underset{\%}{0}\end{array}$ & \\
\hline$A_{1}$ & 0 & -13 & 18,5 & 20,5 & 28,5 & 32,5 & $\begin{array}{c}\text { Linino } \\
\text { argiloso }\end{array}$ \\
\hline $\mathrm{A}_{3}$. & 13 & -43 & 16,0 & 19,1 & 14,6 & 50,3 & Argilosi \\
\hline $\mathrm{B}_{21}$ & 43 & -70 & 14,0 & 18,6 & 14,7 & 52,7 & Argiloso \\
\hline$B_{22}$ & 70 & -105 & 15,5 & 20,5 & 25,5 & 38,5 & Barrento \\
\hline$c_{1}$ & 105 & -180 & 16,0 & 21,7 & 20,8 & 41,5 & ing giloso \\
\hline $\mathrm{c}_{2}$ & 180 & -405 & 16,6 & 23,3 & 21.4 & 38,7 & $\begin{array}{c}\text { Fino areno } \\
\text { barrento }\end{array}$ \\
\hline$D_{1}$ & 405 & -430 & 16,0 & 43,0 & 19,2 & 21,8 & $\begin{array}{c}\text { Fino areno } \\
\text { barrento }\end{array}$ \\
\hline
\end{tabular}

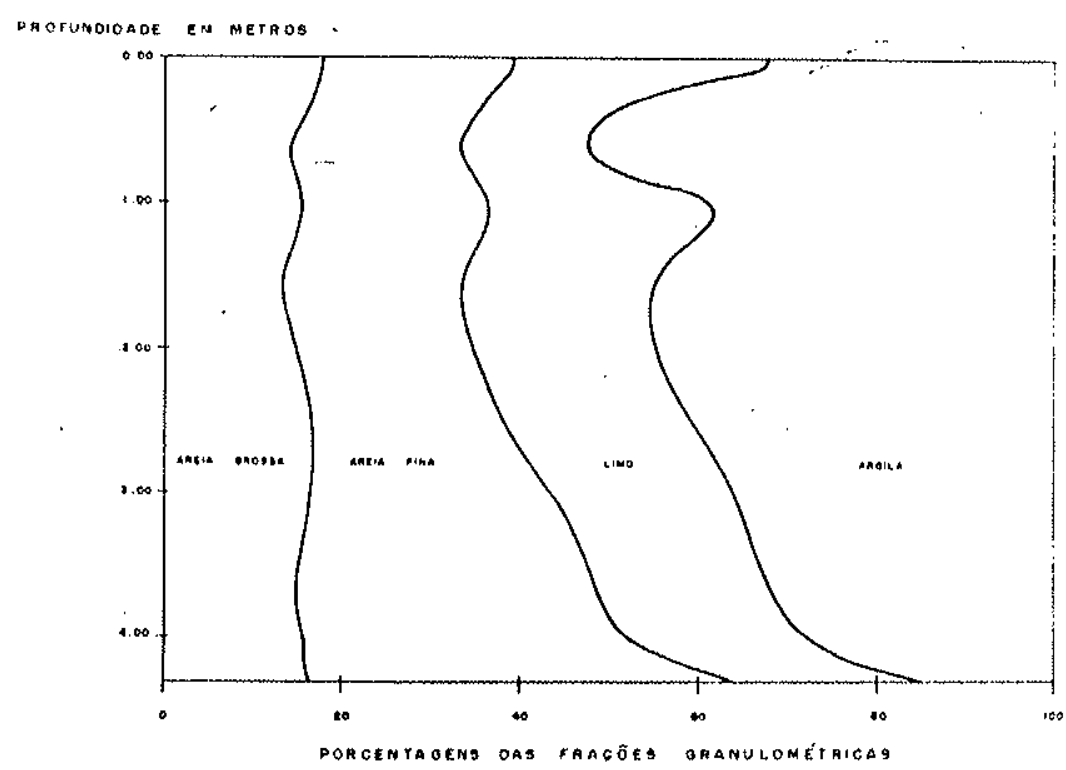

m Fig. 54 - Distribuiço das fraçōes granulométricas no longo do perfil 2 $f_{a}-1$. 
O tcor em argila, que próximo à rocha fresca é inferior a $20 \%$, vai aumentando gradativamente até atingir um teor máximo de $50 \%$ no horizonte $B$,

A fração arieia grossa mantém-se constante ao longo de todo o perfil. Intexpretamos êste fato por ser o matcrial cons tituído principalmente por minerai s estáveis (quartzo e acessórios); por outro lado, a fração areia fina decresce em vixtude de ser constituída por minerais fàcilmente al teráveis (plagioclá sios).

\section{B - Análise miner alógica do perfil}

$$
\mathrm{PA}-17
$$

Rocha fresca. Diabásio de coloração cinza, sensivelmente mais claro que a amostra do perfil antexior. Macroscòpi camente apresenta textura fanerítică granulação tá:. dia. Ao microscópio mostra textura sub-ofítica, com cristais de plagioclásios intercrescidos com piroxênios. Além dêsse intexcrescimento, aparece o de quartzo com feldspato alcalino, conferindo à rocha um caráter granofírico.

A composição mineralógica é a seguinte em \% em vo lume:

$$
\begin{aligned}
& \text { Plagioclásio }-52 \\
& \text { Piroxênios }-31 \\
& \text { Aces sórios }-12 \\
& \text { Quartzo }-5
\end{aligned}
$$

Os plagioclásios apresentam-se xipiformes, possuindo uma composição média por volta de $\mathrm{Ab}_{45} \mathrm{An}_{55}$ e comprimento 
de aproximadamente $0,5 \mathrm{~mm}$. Embora raramente, existem taun bém fenocristais que podem atingir até $2 \mathrm{~cm}$ de comprimento. Mostram-se comumente zonados. Os grãos são predominante mente xenomorfos e hipidiomorfos.

Os piroxênios (augita predominante e pigeonita subordinada) formam prismas curtos, menores que os plagioclásios, mostrando incipiente idiomorfismo.

Os acessórios säo principalmente magnetita e ilmenita, com apatita subordinada. Nesta amostra, a apatita não só ocorre como agulhas finas, mas também como prismas dé secção hexagonal.

O quartzo, que aprosenta intercrescimento gráfico com o feldspato potássico, aparece intersticial, constituindo $5 \%$ do volume total.

Ao microscópio, foram constatados alguns grãos de 0 livina, com tendência idiomorfa, totalmente alterada para mont morilonita (Fig. 55).

Os demais níveis de alteração, apresentam comportamento mineralógico semelhante aos correspondentes do perfil anterior, o que pode ser constatado nas figuras $56,57,58$ e 59 ; asoim sendo, não apresentaremos descrição detalhada da evolu ção mineralógica, limitando-nos sòmente à indicação dos dados obtidos.

A tabela 16 e a figura 60 representam os dados minera lógicos quantitativos do perfil PA-1.

C - Análises químicas

Os resultados apresentados na tabela 17 são referentes 


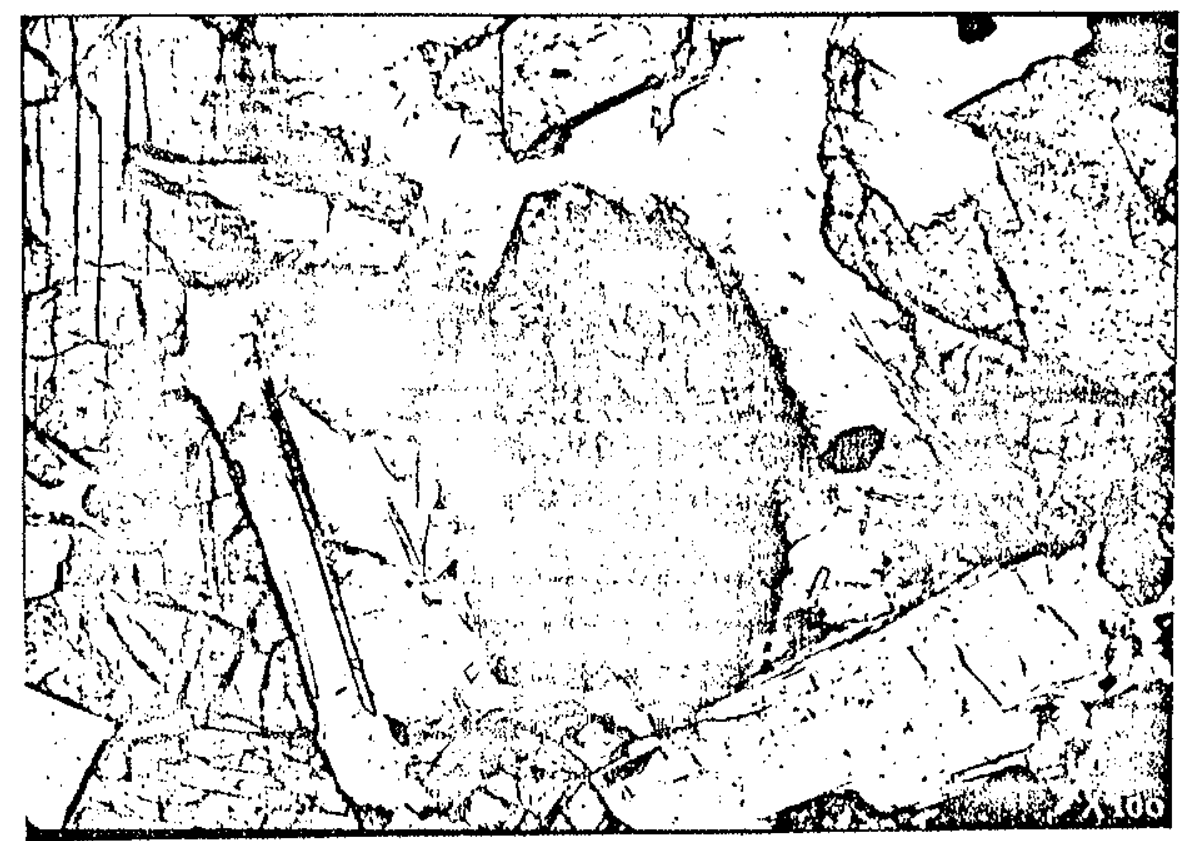

Fig. 55 - Cristal de olivina totalmente alterado para um mineral do grupo das montmorilonitas (possivelmente non tronita).

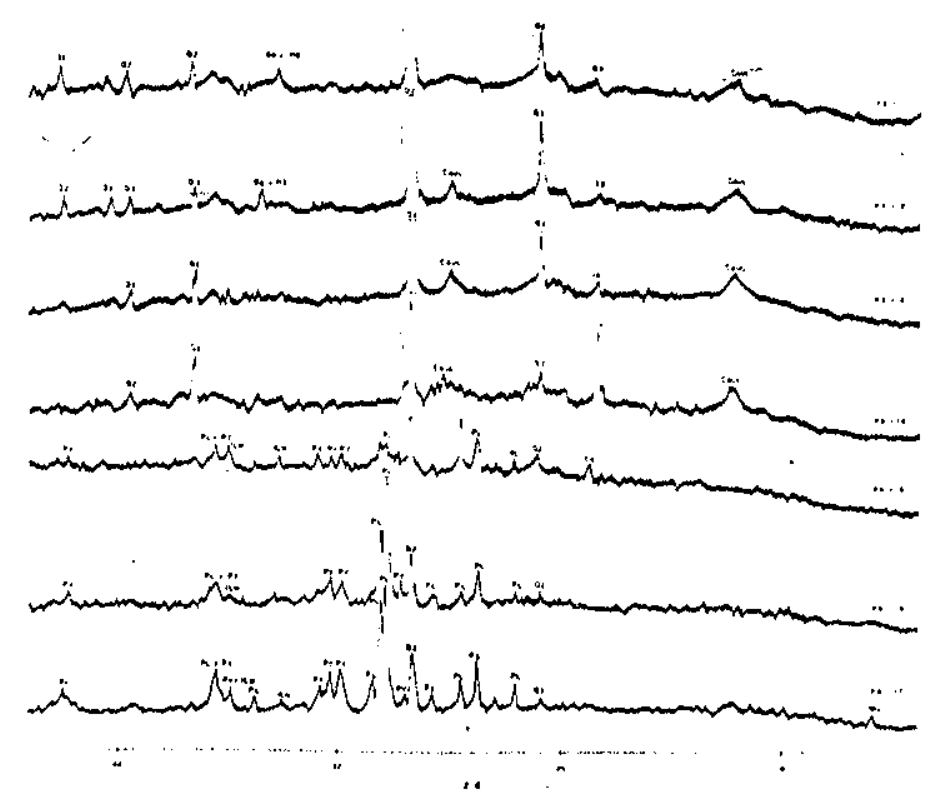

Fig. 56 - Difratogramas dos níveis de alteração do perfil PA-l. Qn.(querizo); Pl(plagioclàsio); Py(piroxênios); ILMi(ilmerita); IVO(montmorilonita); C $\kappa_{i} U L($ caulinita); GB(gib bcila); Go + He (goethita e hematita). 


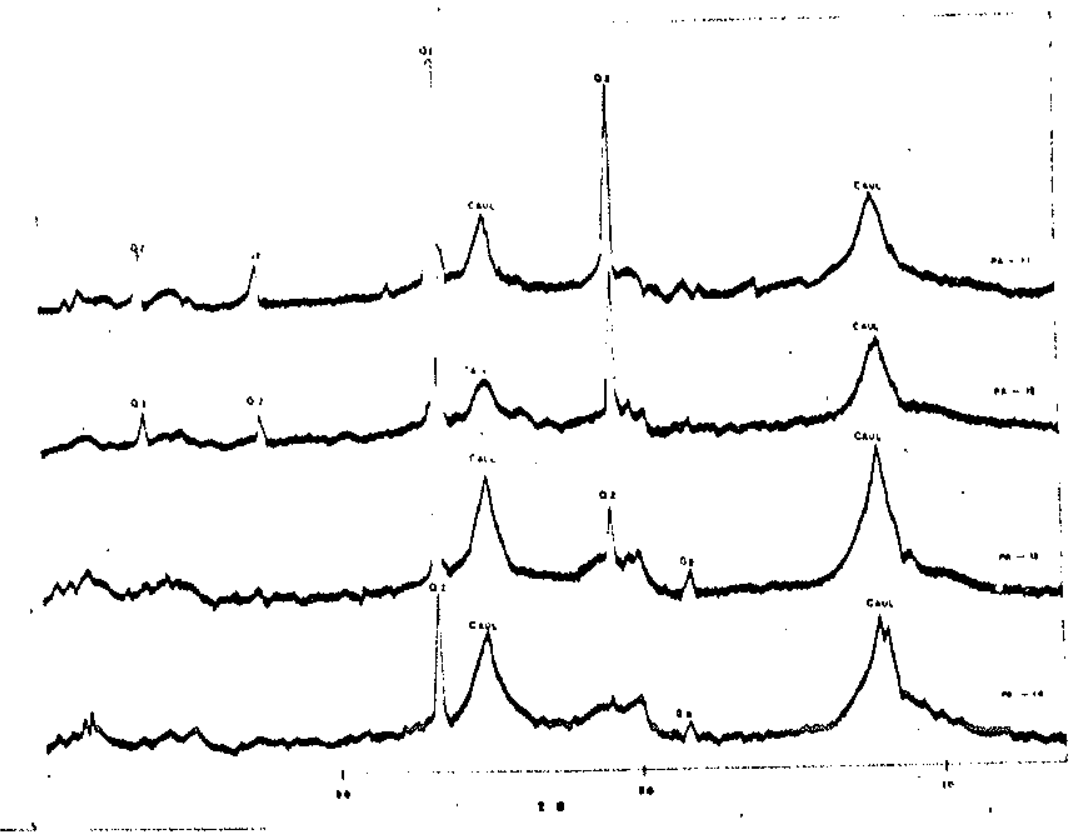

Fig. 57 - Difratogramas da fração limo $(0,0 Z$ $0,002 \mathrm{~mm}$ ) dos diferentes horizontes de alteração do perfil PA-l.

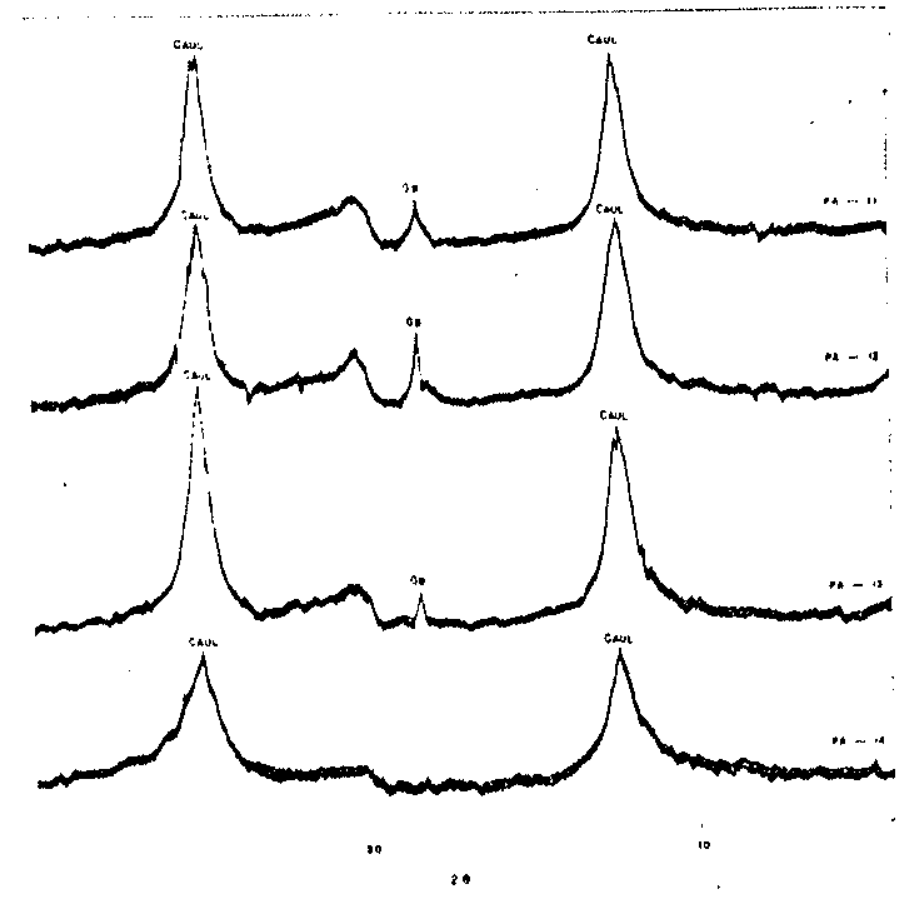

Fig. 58 - Difratogramas da fração argila(menor que $0,002 \mathrm{~mm}$ ) dos diferentes horizontes do perfil PA-l. 


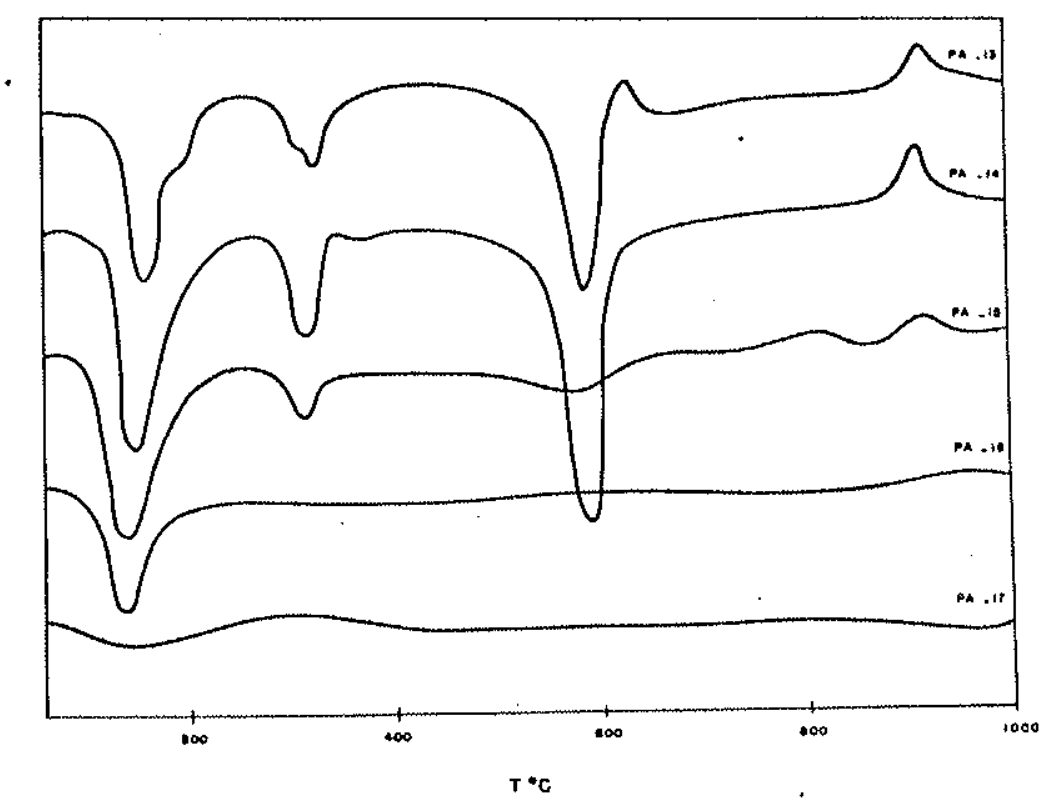

Fig.59 - Termogramas da fração argila dọs níveis de alteraçäo do perfil PA-1. Picos endotérmicos por volta de $300^{\circ} \mathrm{C}$ revelam a existência de gibbsita. Os picos endotérmicos entre 575 e $600^{\circ} \mathrm{C}$ são da caulinita. A grande amplitude dos picos entre 105 e $150^{\circ} \mathrm{C}$ deve-se provàvelmente a cxistência de grandes quantidades de material amorfo. 
TABELA 16

Composição mineralógica dos diferentes níveis de alteração do perfil $P f_{2}-1$ em $\%$ (volume) $P A-17$ PA-16 PA-15 PA-14 PA-13 PA-12 PA-11

Plagioclásio

52

33

25

Piroxenio

31

28

21

Clivina

Acessórios

11

$1+8$

16

20

$12 \quad 18$

18

Quartzo

5

7

10

15

19

32

Gibbsita

10

18

35

15

- 11

6

Montmorilonita

Caulinita

20

40

37

30

Goethita

5

10

16

18

15

14

Halloysita

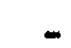

tr.

tr.

tr.

tr.

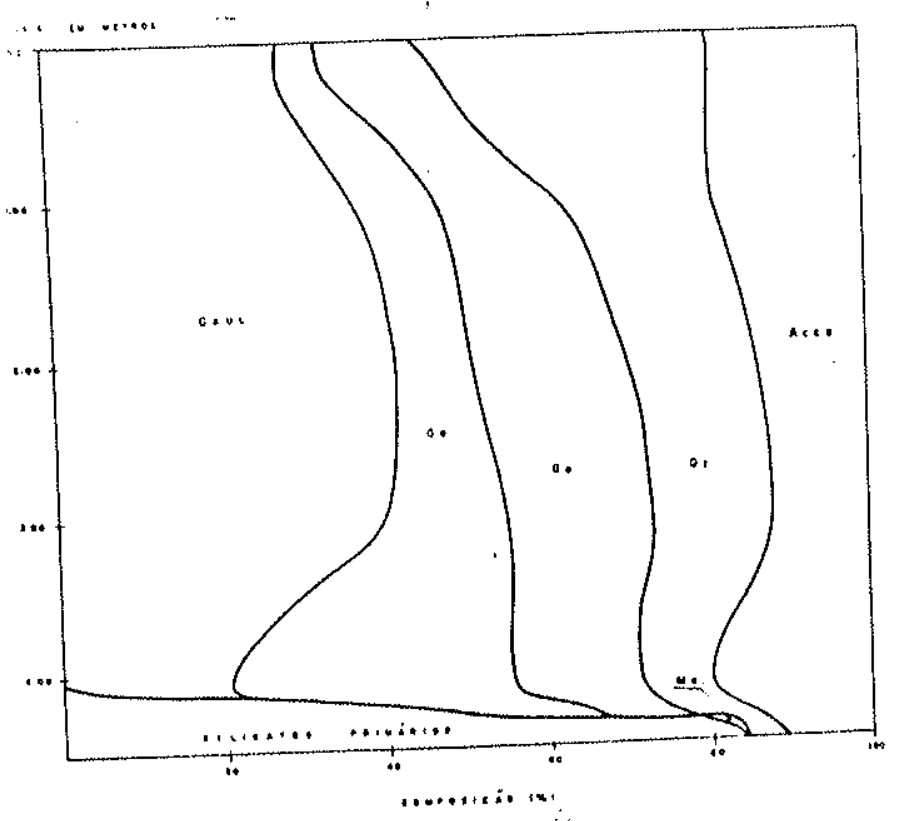

Fig. 60 - Esquema mineralógico do perfil PA-l 
TABELA 17

Análises químicas totais do perfil $P A_{1}-1$ (porcentagem pōso) e porcentagens a volume constante calculadas a partir das análises químicas

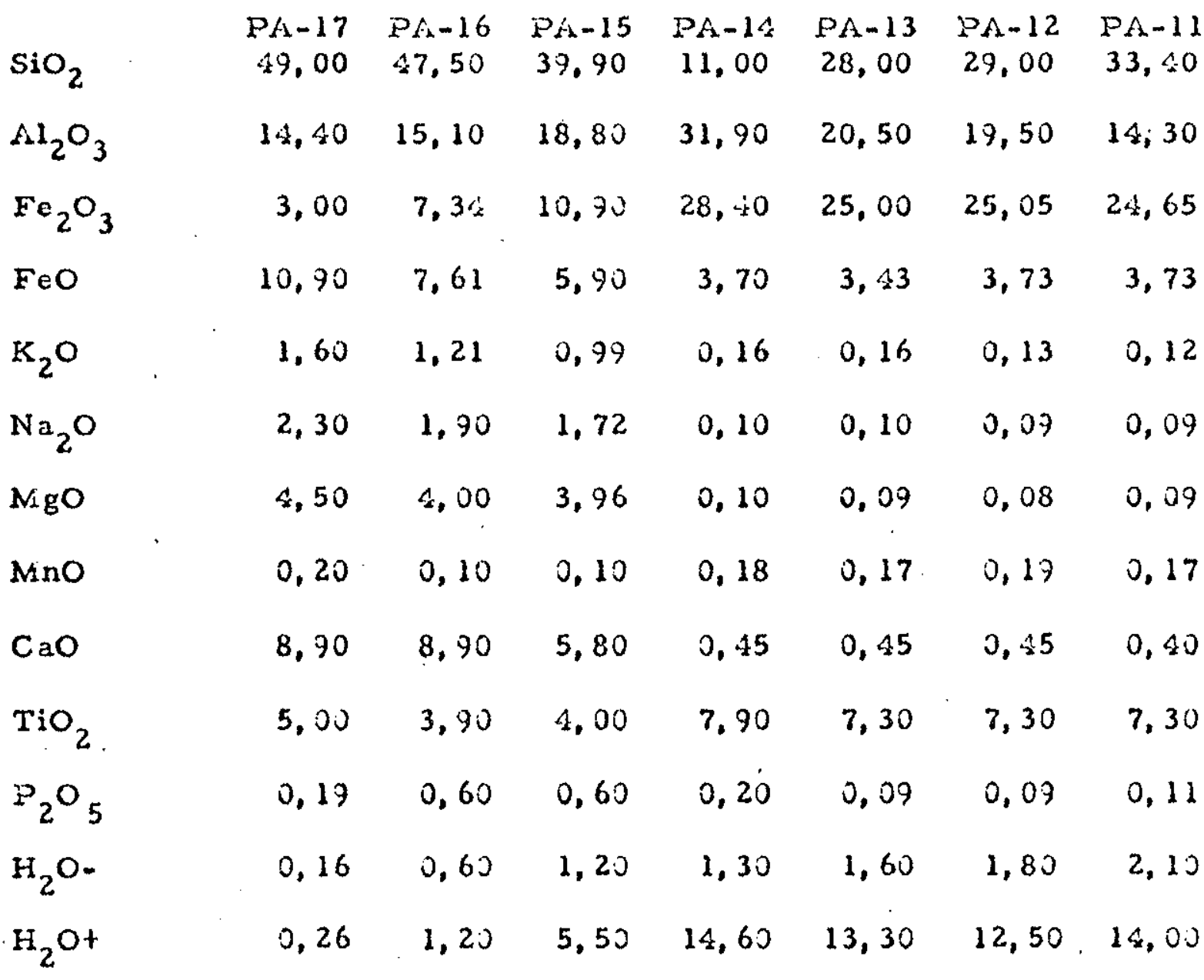

Total

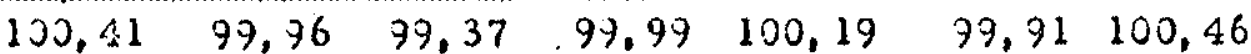

Dens,apar. $\quad 3,01 \quad 2,82 \quad 2,50 \quad 1,50 \quad 1,08 \quad \cdot 1,16 \quad 1,28$

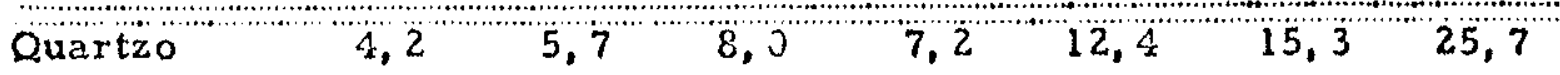

\begin{tabular}{|c|c|c|c|c|}
\hline $\mathrm{SiO}_{2}$ & $-12,6$ & -40.9 & $-75,8$ & $-87,5$ \\
\hline $\mathrm{Al}_{2} \mathrm{O}_{3}$ & $-1,6$ & $+8,5$ & $+10,6$ & $-48,9$ \\
\hline FeO total & $-22,1$ & $+0,2$ & $+1,5$ & $-26,6$ \\
\hline $\mathrm{K}_{2} \mathrm{O}$ & $-29,1$ & $-54,2$ & $-75,8$ & $-96,2$ \\
\hline $\mathrm{Na}_{2} \mathrm{O}$ & $-21,7$ & $-37,6$ & -98.3 & $-78,6$ \\
\hline $\mathrm{MgO}$ & $-16,3$ & -28.1 & -38.7 & $-99,3$ \\
\hline $\mathrm{CaO}$ & $-6,3$ & -45.9 & -97.4 & $-98,1$ \\
\hline $\mathrm{H}_{2} \mathrm{O}$ total & +292 & +1184 & +1760 & +1130 \\
\hline
\end{tabular}


às análioes químicas c aos cálculos isovolumétricos doo níveis de altcração do perfil PA-1.

$$
3 \text { - Perfil AM- } 1
$$

Neste perfil de alteração foram coletadas amostras correspondentes apenas ao material fresco, parcial e totalmente al terado.

A - Análise mineralógica do perfil

$$
A M-13
$$

Rocha fresca. Diabásio cinza escuro holocristalino, apresentando textura fanerítica predominantemente ofítica, po dendo ocorrer também a sub-ofítica.

A compósição mineralógica é a seguinte em \% em vo -

lume:

$\begin{array}{ll}\text { Plagioclásios } & -52 \\ \text { Piroxênios } & -30 \\ \text { Olivina } & -5 \\ \text { Acessórios } & -13\end{array}$

O plagioclásio, mineral predominante da rocha, pos sui uma composição ligeiramente mais cálcica que a apresentada por aquêles dos diabásios estudados anteriormente ( $\mathrm{Ab}_{40} \mathrm{An}_{60}$ ). Possui forma de ripas, sendo comum a ocorrência de cristais zonados.

O piroxênio é principalmente augita, com pigeonita su bordinada. Seus cristais são ligeiramente maiores que os plagio 
clásios e quase sempre apresentam formas Idiomorfas.

A olivina ocorre em teor subordinado, formando cristais idiomorfos. O alto valor de seu ângulo ' Axial evidencia. tratar-se de crisolita. Os cristais de olivina apresentam núcleos inalterados, separados por fissuras preenchidas por material opaco, não identificado.

Os acessóxios são principalmente magnetita, ilmeni ta, com apatita subordinada.

$A N_{1}-12$

Rocha parcialmente alterada, formando uma crosta que recobre a rocha fresca, apresentando espessura por volta de $4 \mathrm{~cm}$. Apresenta color ação cinza clara.

A olivina é o primeiro mineral a desaparecer do perfil, transformando-se totalmente em um argilo-mineral do grupo das montmorilonitas. Alguns grãos de olivina ainda ocorrem parcialmente alterados neste nível. O estudo aos raios $\mathrm{X}$ de alguns cristais com forma externa de olivina, neste estádio de alteração, evidenciou a ocorrência única e exclusiva de um mineral do grupo das argilas trioctaédricas, possivelmente nontroni ta (Fig. 61).

Os plagioclásios mostram-se alterados, apresentando em suas faces e ao longo de suas clivagens e fissuras, substân. cias amorfas, incolores e totalmente isótropas. Este material. que ocorre em quantidades notáveis, representaria o primeiro estádio da alteração dos plagioclásios. Concomitantemente, pequenos cristaís de caulinita começam a cristalizar-se em detex minados pontos, no seio dêste gel, ou diretamente a partir dos 
dos plagioclásios.

Os piroxênios possuem uma resistência maior ao in temperismo. Suas clivagens sofrem um aumento de espessura . sendo preenchidas por substâncias avermelhadas, que podem sex relacionadas à hidróxidos do ferro que por vêzes tingen comple tamente os cristai s existentes nas lâminas (Fig. 62). Em alguns casos.. suas clivagens se desenvolvem de maneira tão acentuada que causam a separação de núcleos frescos de piroxênios; por fim, em estádios mais avançados, o pxóprio núcleo se transforma totalmente em goethita e/ou hidróxido de ferro amorfo (Fig. 63).

Parece lógico admitir que parte da montmorilonita seja formada ̀̀s expensas dos piroxênios, e não só a partir da oliví na, onde ela aparece pseudomórfica sổre seus cristais. Entre tanto, näo temos nenhuma evidência direta dêste fato.

\section{$A N_{i}-11$}

Rocha totalmente decomposta, representando o horizon te C do solo hidromórfico. Niaterial argiloso amarelo-esverdeado, que pode alcançar $50 \mathrm{~cm}$ de espessura.

A olivina desapareceu totalmente do perfil, transfor mada em nontronita.

O plagioclásio se apresenta bastante alterado para cau linita, subsistindo ai nda, em parte, o material amorfo do hori zonte anterior, o qual aparece ainda cm quantidades apreciáveis (Fig. 64).

A caulinita torna-se o principal mineral do horizonte . ao lado de montmorilonita. 


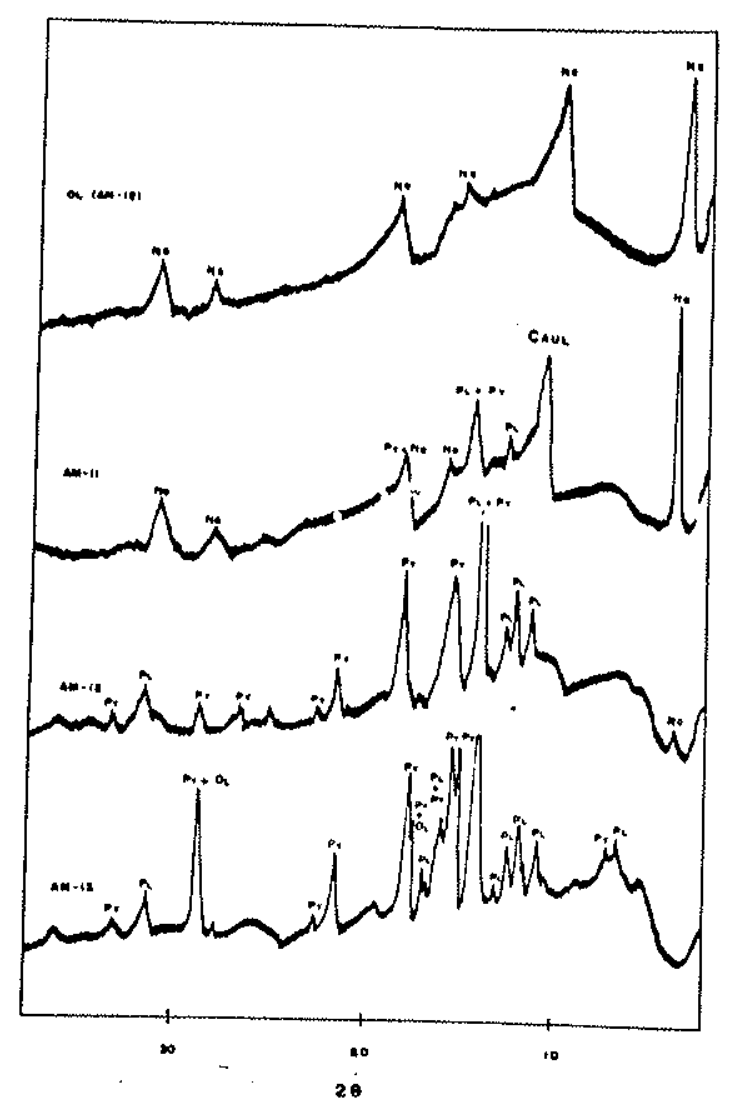

$-138-$

Fig. 61 - Difratogramas dos níveis de alteração do perfil AM-1. $P 1$ (plagioclásio); Py(piroxênio); Ol(olivina); NO(nontronita);CAUL(caulinita). A amostra Ol(ANi-12) corresponde a cristais de olivina do horizonte $A N_{\perp}-12$ substituŕdos pseudomòrficamente por nontronita.

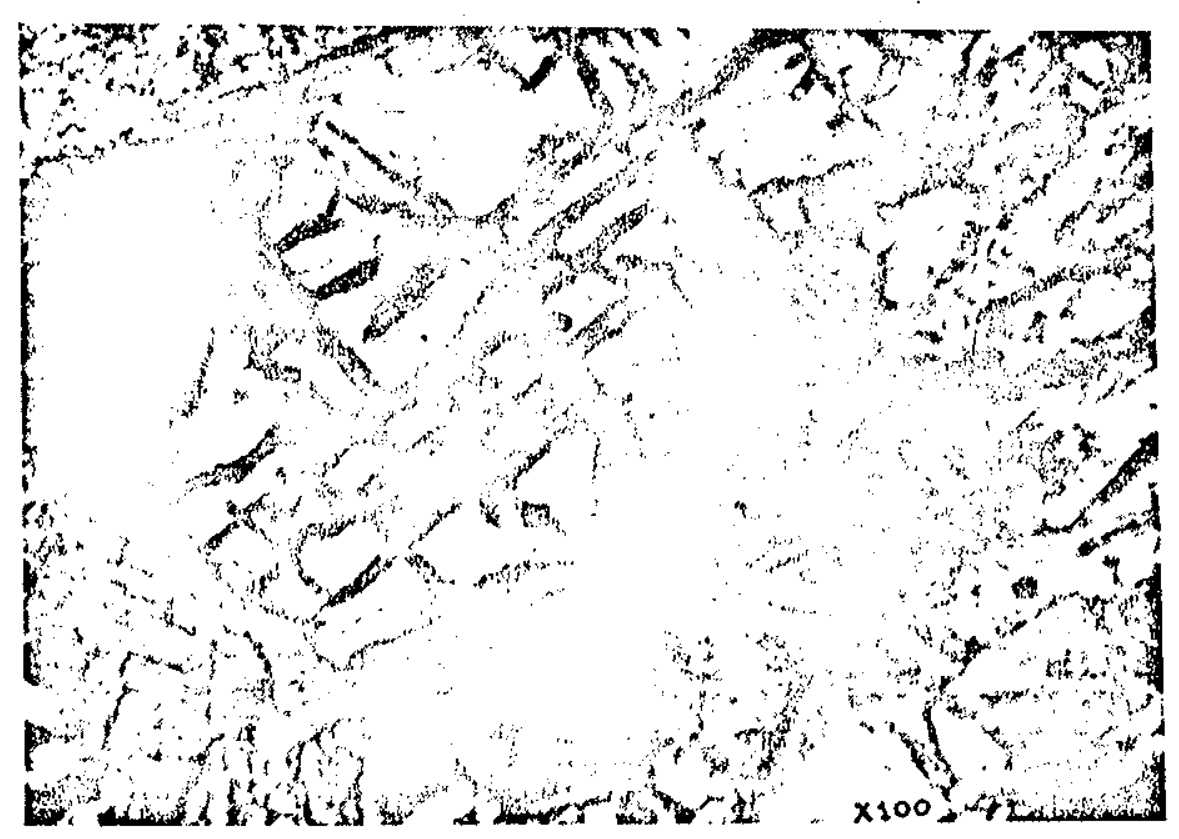

Fig. 62 - Estádio inicial de alteração dos piroxênios. Observase a existência de núcleos inalterados de piroxênios separados por hidróxido de ferro que acentua suas clivagens. 


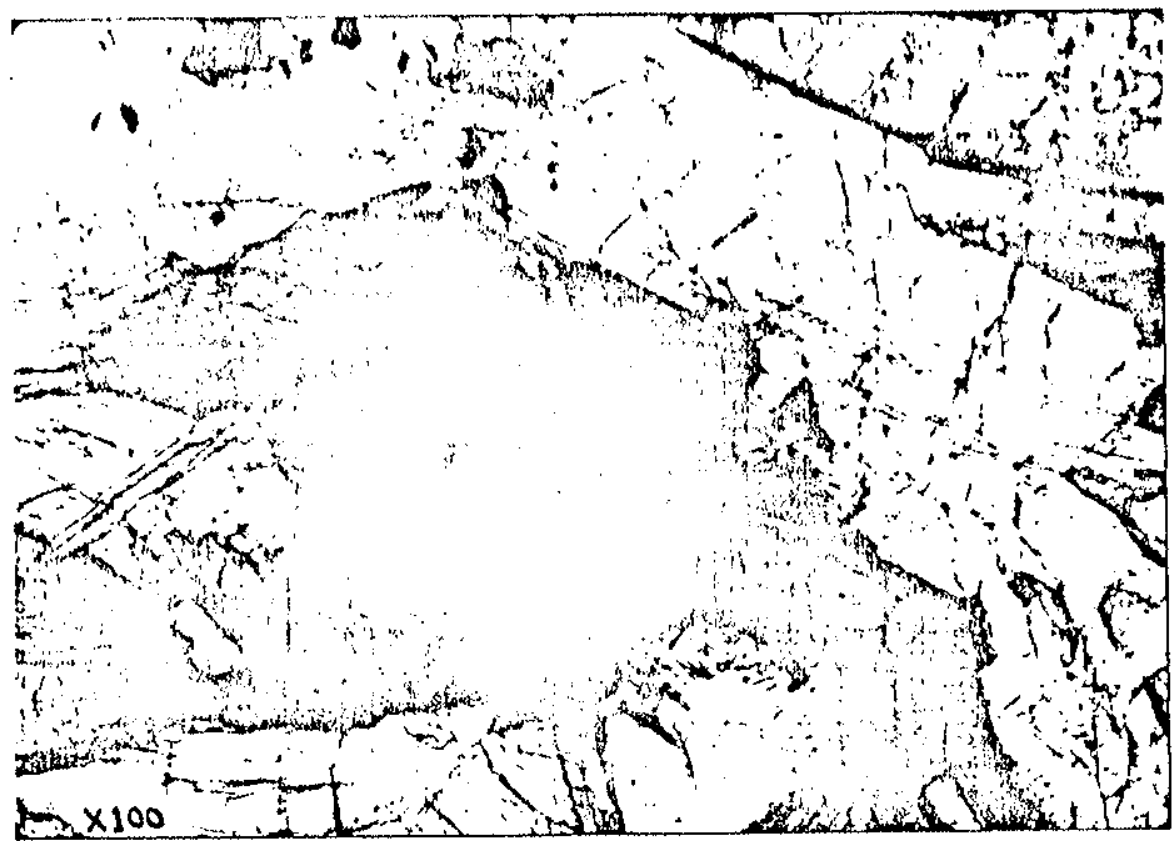

Fig. 63 - Estádio mais avançado na alteração dos piroxênios, observando-se um cristal de piroxênio totalmente transformado em hidróxido de ferro (goethita).

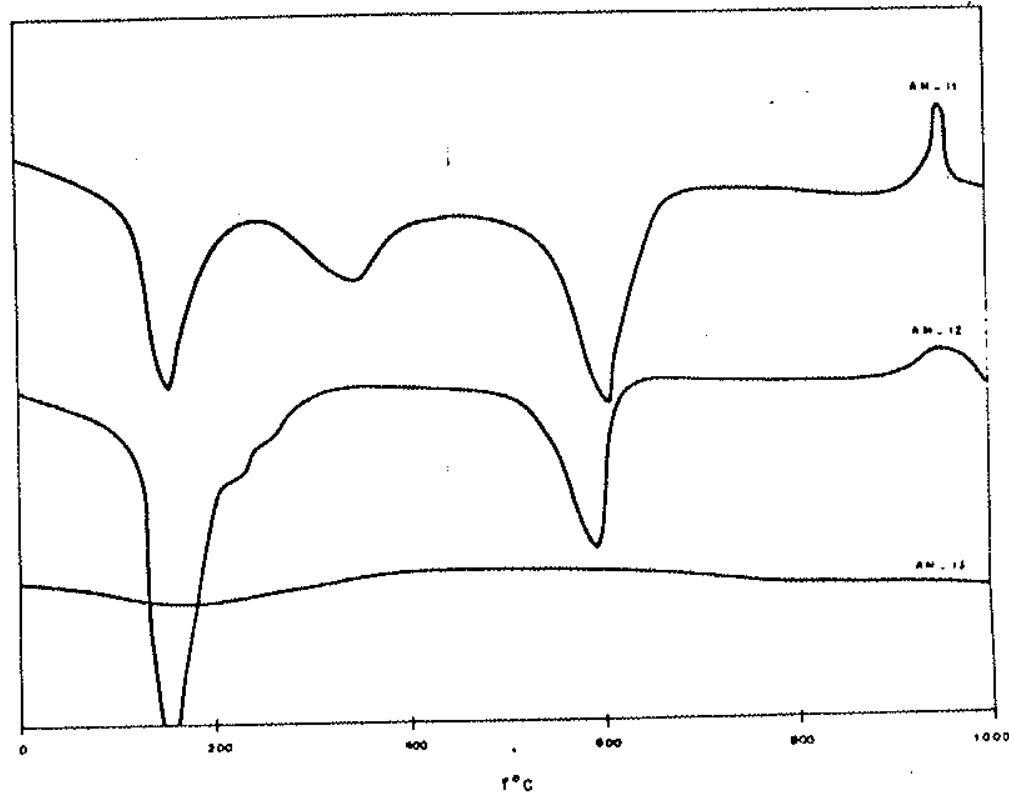

Fig. 64 - Termogramas dos diferentes níveis de alteraşa ão do perfil AN-1, notaido-se a presença de caulinita(pico endotérmico ¿ $575^{\circ} \mathrm{C}$ ). Goethita (pico cndotérmi co entre 350 e $385^{\circ} \mathrm{C}$ ) e glande ouantidade de matorial amorfo (pico endotérmico entre 105-125 $\mathrm{C}$ ). 
Neste horizonte, a observação do material ao microscópio eletrônico evidenciou uma concentração razoável de halloy sita (Fig. 65), cuja quantidade não foi determinada em virtuded. grande dificuldade que êste mineral apresenta no que diz respeito à sua identificação.

A tabela 18 e a figura 66 representam os dados mineralógicos quantitativos do perfil $\mathrm{AN}_{1}-1$.

\section{B - Análises químicas}

As análises químicas e Os cálculos isovolumétricos dos diferentes níveis de alteração do perfil $A M-1$ são apresenta dos na tabela 19. 


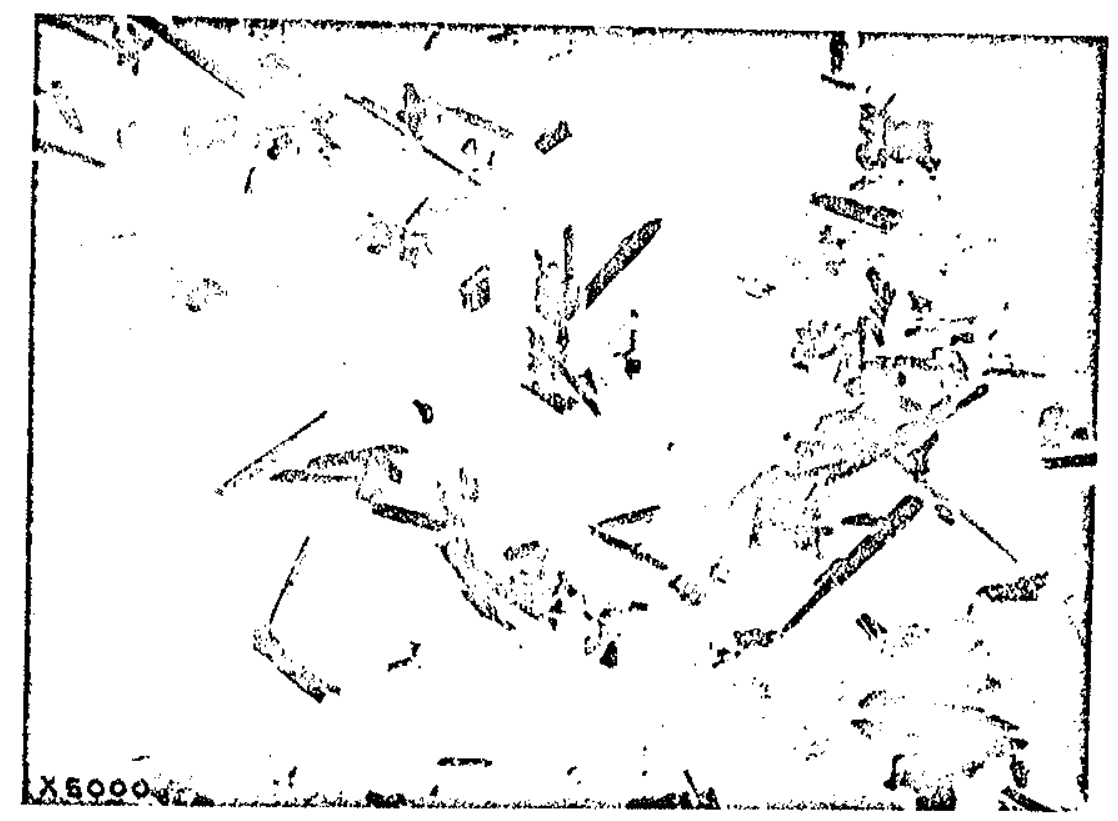

Fig. 65 - Micrografia eletrônica da fração argila do nível $A N_{1}-11$, notando-se uma concen tração anormal de halloysita, não representativa para o horizonte. 
TABELA 18

Composição mineralógica dos diferentes níveis de altcraça do do 2 xill-Alvi-1 em \% (volume)

$$
A N_{+}-13 \quad A M-12 \quad A M-11
$$

$\begin{array}{lccc}\text { Plagioclásios } & 52 & 24 & 22 \\ \text { Piroxênios } & 30 & 20 & 10 \\ \text { Olivina } & 5 & 1 & - \\ \text { Acessórios } & 13 & 15 & 17 \\ \text { Niontmorilonita } & - & 10 & 19 \\ \text { Caulinita } & - & 3 & 23 \\ \text { Goethita } & - & 7 & 9 \\ \text { Fialloysita } & - & \mathrm{tr} . & \mathrm{tr} .\end{array}$

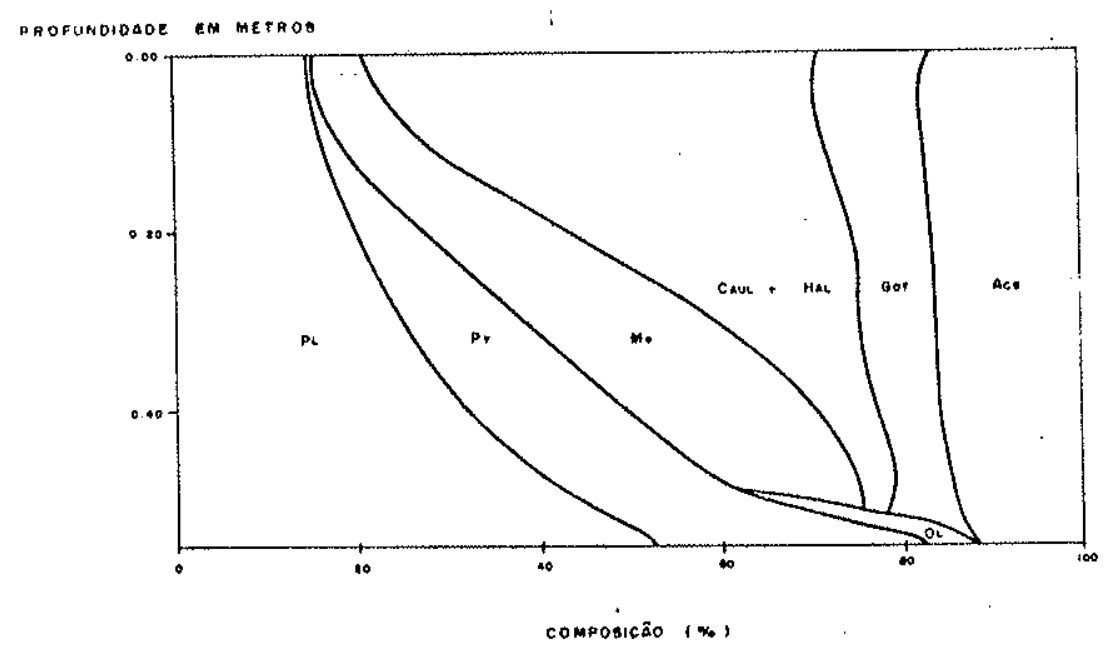

Fig. 66 - Esquema mineralógico do perfil $A_{1}-1$ 
TABELA 19

Análises químicas totais do perfil $A M-1$ (porcentagem pêso) porcentagens a volume constante calculadas a partir das análises químicas

\begin{tabular}{|c|c|c|c|}
\hline & $A M-13$ & $A N_{1}-12$ & $A M_{1}-11$ \\
\hline $\mathrm{SiO}_{2}$ & 47,30 & 46,20 & 42,90 \\
\hline $\mathrm{Al}_{2} \mathrm{O}_{3}$ & 14,20 & 14,96 & 20,50 \\
\hline $\mathrm{Fe}_{2} \mathrm{O}_{3}$ & 3,36 & 6,31 & 9.72 \\
\hline $\mathrm{FeO}$ & 9.30 & 5,80 & 1,00 \\
\hline $\mathrm{K}_{2} \mathrm{O}$ & 0,75 & 0,70 & 0,50 \\
\hline $\mathrm{Na}_{2} \mathrm{O}$ & 2,75 & 1,50 & 0,39 \\
\hline $\mathrm{NigO}$ & 6,84 & 5,00 & 2,20 \\
\hline $\mathrm{CaO}$ & 10,52 & 9,00 & 2,50 \\
\hline $\mathrm{N} n \mathrm{nO}$ & 0,20 & 0,15 & 0,16 \\
\hline $\mathrm{TiO}_{2}$ & 2,85 & 3,00 & 3,00 \\
\hline$P_{2} O_{5}$ & 1,02 & 0,74 & 0,25 \\
\hline $\mathrm{H}_{2} \mathrm{O}-$ & 0,16 & 2,32 & 7,52 \\
\hline $\mathrm{H}_{2} \mathrm{Cl}$ & 0,50 & 4,00 & 10,40 \\
\hline Total & $-99,75$ & 99,68 & 101,04 \\
\hline Dens. apar. & 3,14 & 2,71 & 2,52 \\
\hline $\mathrm{SiO}_{2}$ & & $-15,7$ & $-27,2$ \\
\hline $\mathrm{Al}_{2} \mathrm{O}_{3}$ & & $-7,1$ & $+15,9$ \\
\hline Fe total & & $-17,4$ & $-32,0$ \\
\hline $\mathrm{K}_{2} \mathrm{O}$ & & $-17,3$ & $-43,5$ \\
\hline $\mathrm{Na}_{2} \mathrm{O}$ & & $-52,3$ & $-88,4$ \\
\hline $\mathrm{N} \mathrm{gO}$ & & $-37,2$ & $-74,4$ \\
\hline $\mathrm{CaO}$ & & $-26,3$ & $-80,9$ \\
\hline $\mathrm{H}_{2} \mathrm{O}$ total & & $+71,4$ & +2166 \\
\hline
\end{tabular}


DISCUSSXO DOS RESULTADOS DO INTEN PERISNO SOBRE DIABASIOS E A FORMAÇO DOS PERFIS DE ALTERAĢIO

\section{A - Análise granulométrica}

Os materiais formados pelo intemperismo nos diabá sios são caracterizados pela predominância de frações finas ao longo de todo o perfil, com exceção dos níveis iniciais de altera ção, onde estas fraçōes constituem menos de $30 \%$.

O alto teor das frações de granulaşão fina está direta mente ligado à alta alterabilidade do material formador do diábásio. Os plagioclásios e piroxênios, que constituem cêrca de $80 \%$ da rocha, são minerais fècilmente intemperizáveis que produzem outros de neoformą̧̃o, os quaís se concentram nas frações limo e argila.

Com a evolução do intemperismo, as frações finas têm seus teores altamente aumentados, atingindo o máximo no horizon te $\mathrm{B}_{2} \cdot$

A fração areia grossa é restrita em todo o perfil, atingindo no máximo valores por volta de $15 \%$, sendo constituída quase que única e exclusivamente de opacos (magnetita e ilmenita) e quartzo.

$B$ - Evolução mineral ógica do perfil

Os minerais primários que constituem o diabásio, apre gentam um comportamento uniforme no que diz respeito à sua es - 
tabilidade frente à ação do intemperismo, em todos os perfis ana lisados. Entretanto, a formação dos minerais secundários depen de das condições locais de drenagem.

A olivina é o mineral primário menos estável nas condif̧ões superficiais, sendo o primeiro a desaparecer do perfil. Sua alterą̧̃o deve ser encarada sob dois aspectos: em alguns ca 80s, é possírel que a olivina já se apresenta alterada por proces sos hidrotermais, pois é comum o aparecimento de cristais de $\mathrm{O}$ livina substituŕdos pseudomòrficamente por material amorfo ou por mineral secundário em rocha totalmente fresca. Nielfi e Gi rardi (1962), estudando diabźsios de profundidade totalmente inal terados, obtidos a partir de testemunhos de sondagens, encontra ram produtos de alteraçäo pseudomórficos sôbre olivinas.

Em outros casos, a alteração, das olivinas está intima mente correlacionada a fenômenos intempéricos, como no caso do perfil $A N_{+}-1$, onde cristais de olivina inalterados são encontra dos na rocha original. Neste perfil, o estudo do material através dos raios $X$ mostrou uma rápida evolução da olivina para um rna terial caracterizado por uma forte reflexão a $14 \AA$. O material tratado com etileno glicol apresenta um deslocamento da refle xão para $17 \AA$, o que permite concluir tratar-se de um mineral pertencente ao grupo das montmoxilonitas.

A natureza do material formado durante a alteração das olivinas, tem sido motivo de numerosos estudos por parte de vários autores. Bonifas (1959), estudando a ação do intcmperismo nos doleritos de Konkoure, detcctou no produto de alteração das olivinas a existéncia de un mineral do grupo das montmorilonitas misturado com goetinita. Smith (1961), estudanto olivinas 
dos basalto de Edimburgo mostrou a existência de pseudomorfos constituídos de saponita, goethita e hematita. Pécrot et al.(1962) nos solos do Kivu, identificou nontronita como produto da alteração de olivinas. Craig and Loughnan (1964) chegaram a resulta dos que corroboraram o trabalho de Smith, pois estudando a alte raçäo das olivinas dos basaltos de Nova Gales do Sul, encontra ram.idding gita, determinada òpticamente. Entretanto, êste mate rial, analisado aos raios $X$, revelou tratar-se de um mineral do grupo das montmorilonitas associado a óxidos e (ou) hidróxidos de ferro. Finalmente Delvigne (1965) denominou iddingsita o produto da alteração intempérica das olivinas dos diabásios encontra dos em côte d'Ivoire.

Os plagioclásios calco-sódicos são,depois das olivinas, os minerais que apresentam menor resistência à ação do intem perismo. Em tcdos os perfis, com exceção do Ali-1 notarse, jé nos horizontes inferiores do perfil, total desaparecimento de seus cristais. O primeiro estádio de alterayão dos plagioclásios é a formação de gels amorfos, tanto nos perfis que se desenvol veram em condições de drenegem moderada ou boa, quanto naqueles formados em condições de hidromorfia; e nestes últimos, os gels possuem grande estabilidade.

Nos perfis bem e moderadamente drenados, concomi tante com a formação incipiente de gels, pode-se desenvolver a cristalização de gibbsita, que é o primeiro mineral formado a partir da alteração dos plagioclásios. Nestes estádios iniciais, a gibbsita substitui pseudomòrficamente $O B$ plagioclásios, concen trando-se desta mancira nas frajōos granulométricas mais gros seiras e não sendo detectada nas fraçōes limo e argila. 
Com a evolução do perfil, a gibbsita apresenta rápida di minuição em seu teor, associada a um progressivo aumento de cau linita. Como no caso já citado dos perfis de alteração desenvolvi dos sôbre granitos, tal fato pode ser interpretado como ressilicifi cação de gibbsita para caulinite (Goldman, 1955, Delvigne, 1765 e Watson, 1965).

Paiva Netto e Nascimento (1957) explicam a evolução de alteração dos plagioclásios para gibbsita e dêste para caulinita, ba seados no fato de que o $\mathrm{pH}$ existente quando a silica é liberada dos silicatos aluminosos favorece seu alto grau de dispersão o que facilita a sua lixiviação. Nos estádios posteriores, as condições existentes possibilitam a polimerizaçäo das moléculas de $\mathrm{SiO}_{2}$, per mitindo a formação de núcleos caulínicos.

No perfil AM-l que apresenta uma evolução dentro de condiçōes de drenagem deficiente, os plagioclásios alteram-se Pa ra um material amorfo, que Bonifas (1959) e Delvigne (1765), estudando solos africanos, interpretaram como alófana. A partir dêste material amorfo, ou diretamento do plagioclásio, ocorre a for mação de caulinita, que nestas condiçōes se apresenta como um dos minerai s de maior estabilidade dentro do perfil, tendo o Beu teor aumentado de maneira marcante em direção à superfície.

A halloysita, em tôdas 23 amostras analisadas ao micros cópio eletrônico, foi observada em pequenas quantidades. Porćm. no perfil $\mathrm{AM}-1$ atinge uma concentração razoável, associada à cau linita. Esta associą̧ão tem sido descrita com frequência em per fis desenvolvidos em condições de drenagem deficiente (Allexander et al., 1943, Allen, 1948 e Pécrot et al., 1962). Segundo Bates (1952) em condiçōes de má dxenagem, há a formação de mistuxa de halloy. sita e caulinita. não sendo necesaćrio pensar - se em desidratação 
da halloysita para formar caulinita. Fauser (citado por Bonifas. 1959) considera a halloysita um têrmo intermediáxio entre um gol de sllício e alumínio e caulinita.

Nossas observações permitem apenas que correlacionemos sua ocorrência a condições de drenagem defeituosa, es tando fntimamente associada à caulinita.

A alteração dos plagioclásios, assim como a dos felds patos dos perfis graníticos, é controlada principalmente peladre nagem. Nos casos dos perfis bem drenados, a sillica liberada é pràticamente eliminada por completo, havendo consequentemente um baixo teor de sillica disponível na solução, o que favorece a formação de gibbsita nos estádios iniciais de alteração. No caso de drenagem defeituosa, a baixa lixiviação existente promove uma alta concentração de sillica na solução, criando condições que favorecem a formação de caulinita (Fig. 67).

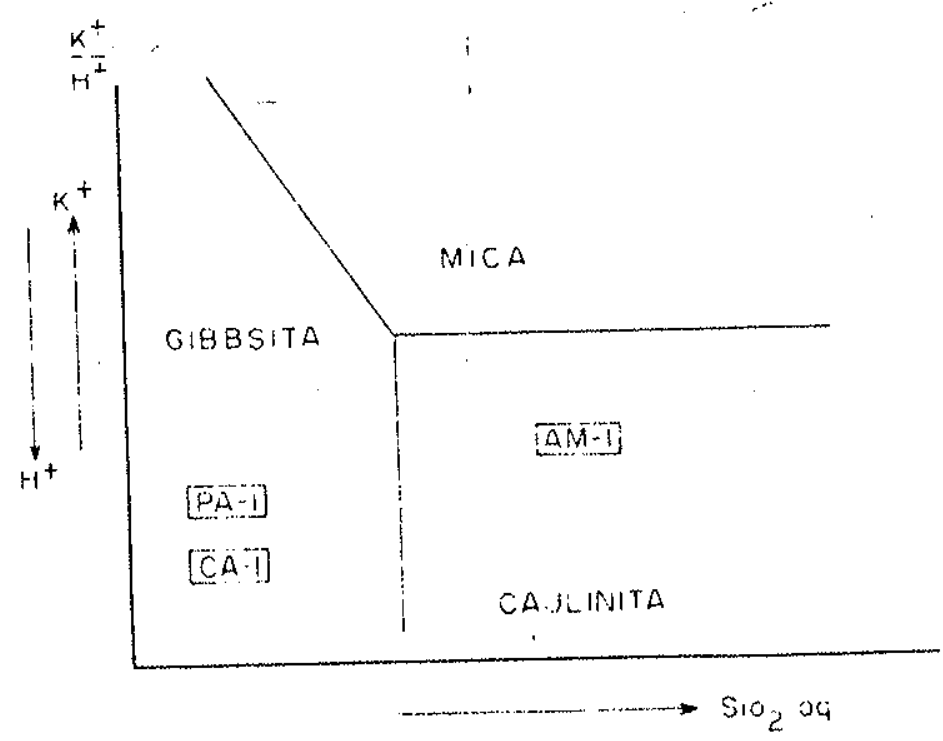

Fig.67 - Diagrama de fase esqueizático fara o sistema $\mathrm{K}_{2} \mathrm{O}_{\text {; }}$ $\mathrm{Al}_{2} \mathrm{O}_{3}-\mathrm{SiO}_{2}-\mathrm{H}_{2} \mathrm{O}$ a $25^{\circ} \mathrm{Ce} 1$ atm de pressão total, vá
lido para os estádios iniciais de alteraço dos per fis estudados. 
O plroxênio é dos silicatos primários do diabásio, o que olerece maior resistência à ação do intemperismo, ligeiramente superior à dos plagioclásios.

O primeiro estádio de alteraçāo dos piroxênios é ca racterizado por pequena perda de ferro, causada por soluções que percorrem o interior dêsses minerisis ferro-magnesianos a través das fraturas e clivagens, formando um reticulado bastan te regular.

Geralmente o ataque é feito a partir das linhas de clivagem, acentuando primeiramente suas direçöes, e às vêzes a té provoca a separação de núcleos inalterados de plroxênios, com as bordas manchadas por hidróxido de ferro.

A alteração progride, havendo uma diminuição do nú cleo inalterado, que finalmente evolui totalmente para hidróxido de ferro. Não notamos em nenhum caso a formação de gibbsita a partir da alteração dos piroxênios, fato comum na alteração dos feldspatos. E possível que a não formação de gibbsita se prenda ao "pli de abragão" dos piroxênios. Stevens and Carron (1948) determinaram para augita um valor do "pH de abrasão" igual a 10. Em tal pH, o ferro liberado da alteração precipita na forma de hidróxido, enquanto que o alumínio se encontra no do mínio da solubilidade, na forma de anion aluminato, que é elimi nado na forma solúvel. Nos feldspatos o pH mais baixo possibili ta sua precipitação na forma de hidróxido.

O valor do $\mathrm{pH}$ de abrasão dos piroxênios permite tam bém que a sílica permaneça em solução, ficando assim explicado porque sòmente há a formação de hidróxido de ferro (goethi ta) (Fig. 68). 


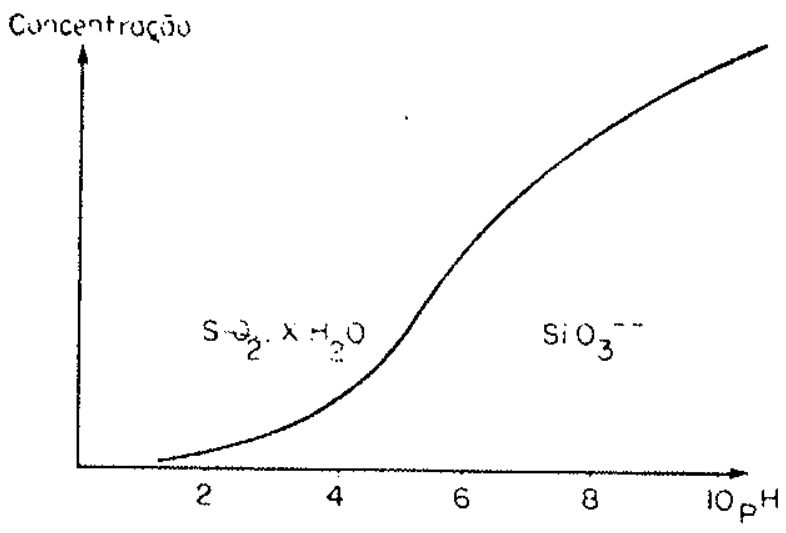

Fig. 68 - Diagrama de solubilidade da sílica em função do pH.

Nos perfis mal drenados os piroxênios podem também se alterar em montmorilonita, pois a falta de lixiviação intensa permite maior retenção dos cátions $(\mathrm{Ca}, \mathrm{Mg}$ e $\mathrm{Fe})$ e da sílica. Niesmo nos perfis bem ou moderadamente drenados. nos estádios iniciais há a formação de montmorilonita, que po do estar relacionada com a alteração de olivinas e piroxênios. A explicação seria a mesma anterior, pois teríamos concentra ção mais alta de cátions e valores elevados de pH (por volta de 10).

C - Comportamento geoguímico dos elementos

Com base nos dados fornecidos pelas análises quími cas totais e nos cálculos isovolumétricos, estabeleceu-se o com portamento geoquímico dos elementos principais do perfil. 
Comportamento do silício

Nos perfis bcm drenados, o silício liberado na alteração dos silicatos comporta-se de maneira uniforme, sendo eliminado quase que totalmente, já a poucos centímetros da rocha fresca. Nos nívcis correspondentes à rocha totalmente decompos ta dos perfis $\mathrm{CA}-1$ e PA-1, a eliminação atinge respectivamente 85 e $96 \%$; êstes níveis de alteração são caracterizados pela ocor rência de gibbsita. No estádio seguinte, onde começa a forma ̧ão de caulinita com maiox intensidade, a eliminação cai para 82 e $87 \%$ respectivamente.

No perfil $A N_{i}-1$, bastante rico em caulinita, a elimina ção do sulício não atinge $28 \%$ na rocha totalmente decomposta.

Comportamento do alumínio

O comportamento do alumínio é bastante homogềneo em todos os perfis estudados. Os dados isovolumétricos evidenciam ser um elemento que possui pequena mobilidade.

No estádio inicial de alteração, apresenta ligeira per da, nunca atingindo 10\%; nos estádios seguintes, apresenta um balanço isovolumétrico positivo que atinge no máximo $15 \%$ do ho rizonte correspondente à rocha totalmente decomposta ( $\left.A N_{1}-1\right)$.

A perda inicial de alumínio parece estar correlaciona da ao alto valor que o pH do meio atinge no inßcio da alteração . promovendo a permavência do íon alumínio na solução, o que possibilita a sua eliminação. Nos estádios scguintes, caindo o valor do pH, há a precipitação do alumínio na forma de hidróxido, que fica retido. Paiva Netto e Nascimento (1957) citam ofa- 
to de rochas básicas (basaltoo e diabásios), finamente moídos, rea gixem com água, dando uma suspensão cujo pH atinge ràpidamen te valores superiores a 9. Pedro (1964) determinou para basaltos no início de decomposição, valores de $\mathrm{pH}$ por volta de 9,0 a 9,5 , que ràpidamente caíam para 7,6 no estádio imediato.

\section{Comportamento do ferro}

O comportamento do ferro é bem menos regular que a quêle apresentado pelo silício e al umínio.

Nos perfis $C A-1$ e $P A-1$, em geral, oferro sofre um ligeiro aumento de teor, ligado ao fato de que a boa drenagem permite uma total oxidação do ferro ferroso da roche original, pe ra ferro férrico nos horizontes de alteração. $\mathrm{Fe}^{3+}$ nas condições normais de desenvolvimento de perfis é pouco móvel, preci pitando-se na forma de hidróxido férrico.

No perfil $A M-1$, o comportamento difere bastante, pais as condições de má drenagem do perfil criam um ambiente redu tor, que impede a oxidzção total do $\mathrm{Fe}^{2+}$ para $\mathrm{Fe}^{3+}$. O íon fer roso é solúvel nas condições em que se desenvolve o intemperis mo, o que irá promover sua parcial eliminação do perfil.

Comportamento dos alcalinos e alcalinos terrosos

Nos perfis bem e moderadamente drenados a eliminação de sódio, cálcio e magnécio é bastante pronunciada, atingindo mais de $90 \%$ no horizonte que zorresponde à rocha totalmente decomposta. O magnésio entretanto, é, em todos os casos, eliminado mais lentamente nos estádios iniciais da alteração, não 
ó pelo fato dos piroxênios possuŕrem maior resistência à ação do Intemperismo, mas tambóm pelo fato de parte do magnésio flcar retido na estrutura dos minerais do grupo das montmorilonitas formados nestes cotádios.

Já no perfil $A N_{i}-1$, que representa condições de dxenagem deficiente, a eliminação é taais lenta, atingindo n rocha to talmente decomposta, valores que não atingem $90 \%$ para o ć́lcio; $80 \%$ para o sódio e $75 \%$ para o magnésio.

O comportamento do potássio difere dos demais alcalinos e alcalinos terrosos. Sua eliminação é bem menos acentuada, visto que êste elemento se encontra nos retículos de feldspatos al calinos, minerais que apresentam alta estabilidade nas condiçōes unperficiais de alteração. Além disso, seu alto poder de adsorção permite, após sua liberaşăo dos silicatos primários, fácil entrada nos retículos dos minex ai s de neoformą̧ão, de modo que par te do potássio fica retido no perfil de alteração. 
TERCEIRA PARTE

CONCLUSOES

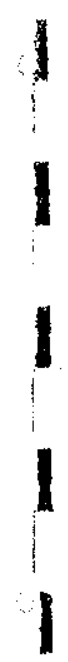




\section{CONCIUSOES}

O estudo mineralógico e químico dos perfis de alteração desenvolvidos sôbre granitos e diabásios permite-nos tirar algumas conclusões sôbre a alterabilidade dos diferentes mine rais constituintes das rochas, sôbre as condiçōes que regem a gênese dos minerais de neoformał̧̃̃o e sôbre o comportamento geoquímico dos elementos maiores, na evolução do perfil.

l - Estabilidade dos minerais primários

A estabilidade relativa dos minerais primários, no de correr do intemperismo, está, de maneira geral, de a côrdo com a determinada por Goldich (1938). Entretanto, o piroxênio considerado por Goldich, mais fàcilmente intemperizado do que os plagioclásios calco-sódicos, mostrou-se, no material estuda do, ser mais resistente: a biotita, que logo nos estádios iniciais apresenta perda de ferro, evidenciada por uma ligeira descolaração dos cristais, possui um campo de estabilidade relativa mente extenso, permanecendo longo tempo no perfil.

Para os granitos e diabásios analisados, podemos estabelecer esquemáticamente a seguinte sequência de alteração:

Olivina

$$
\begin{aligned}
& \text { Biotita } \\
& \text { Pltoxênio } \\
& \text { Plagioclásto cálcico } \\
& \text { Plagioclásio sódico } \\
& \text { Feldspato potás lico }
\end{aligned}
$$


Concluimos, então, que os nesossilicatos (olivina) que possuem tetraedros de silício ligados por cátions altamente solú veis, são fàcilmente alterados, pois uma vez que êstes cátions passam para a solução, não hâ mais nenhuma coesão no intexior do cristal.

A medida que as estruturas silicáticas se complicam, as ligações entre os tetraedros tornam-se mais resistentes à al teração, passando dos inossilicatos (piroxênios) aos foliossilica tos (biotita) e finalmente aos tectossilicatos (feldspatos e quartzo), onde a ligações se fazem nas três dimensões do espaço.

2- Gênese dos minerais de neoformaça

No estudo da gênese dos minerais de neoformação dos perfis de alteração, ficou patente a grande importância dos fenô menos ligados à lixiviação e à drenagem, que dependem em última análise, da quantidade de água e da situação que o material ocupa dentro do relêvo. O material original apenas delimita as possibilidades de transformaşão, não traçando o caminho a ser

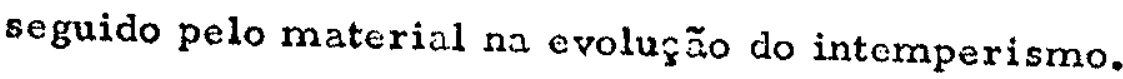

O primeiro minezal de neoformação a se cristalizar é um do grupo das montmorilonitas, provàvelmente nontronita, que 6e forma a partir de olivina, logo no primeiro estádio de alteracão e a partir de piroxênios em estádios posteriores. Sua gêne se se verifica tanto nos perfis que se desenvolvem em condiš̃os de drenagem boa ou moderada, quanto nos desenvolvidos em con dições de drenagem defeituosa.

A estabilidade dêste mineral no solo é precária, desaparecendo $x$ àpidamente do perfil, evoluindo para um outro tipo 
de mineral de argila e hidróxido de ferro.

Nos perfis bem drenados, desenvolvidos sôbre grani tos e diabásios, a gibbsita é o mineral que se crietaliza logo a seguir, o que ocorre ainda nos estádios iniciais da alteração dos feldspatos, antes mesmo dêstes se apresentarem totalmente decompostos. O fato da gibbsita formar - be ao mesmo tempo em que se altera o feldspato, evidencia que aquêle mineral se forma nas condições de hidrólise dos feldspatos, onde o $\mathrm{pH}$ atinge valo

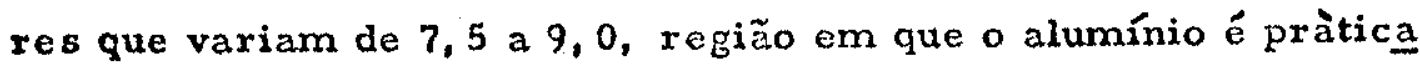
mente insolúvel.

A gibbsita não é um mincral indefinidamente estável nas condições superficiais, podendo ter seu teor diminuído, quer evoluindo para caulinita, quer desaparecendo do perfil. Nas'zonas superiores do solo, parte da gibbsita desaparece devido a presença de matéria orgânica, pois a complexação do alumínio com certos produtos orgânicos permite sua remobilização (Scheu felberger, 1951). A transformação de gibbsita para caulinita (ar gilo-mineral predominante nos nossos solos) está ligada ao processo de ressilicificą̧ão, processo êste comum em regiões tropicais, ocorrendo às expensas da súlica liberada a partir da al teração dos minerais silicáticos foxmadores da rocha, em estádio mais avançado do intemperismo.

Nos perfis de alteração desenvolvidos em condições de drenagem deficiente, a alter aşão dos feldspatos provoca, pri -meiramente, a formaçäo de materiais amorfos, interpretados por vários Autores como allofana. A estabilidade dêstes gels vai depender, principalmente da intensidade das condições de hidro morfia. Apesar de não termos determinado a quantidade de material amorfo dentro do perfil, possuimos evidências seguras de 
que seu conteúdo diminui em direção à superfície, associado a um aumento de caulinita. Este fato sugere a sequência: rocha $\longrightarrow$ material amorfo $\longrightarrow$ caulinita.

Associada à caulinita, principalmente nos perfis de drenagem defeituosa, observa-se a presença de halloysita, que só pôde ser notada com o auxîlio de microscopia eletrônica.

A vermiculita se forma a partir da biotita, tanto nos perfis bem drenados como nos deficiente ou moderadamente, se bem que seu desenvolvimento seja mais pronunciado no primeiro caso. Este mineral é típico dos primeixos estádios da altera ção, possuindo certa instabilidade no solo, evoluindo depois para caulinita ou gibbsita.

A gocthita, cncontrada nos perfis desenvolvidos sôbre diabásios, forma-se a partir da aiteração dos piroxênios e olivi nas. Sua ocorrência se verifica tanto nos perfis bem drenados, como nos deficientemente drenados.

A ausência de gibbsita e a presença de goethita nos produtos da altcração dos piroxênios indicam que sue alterą̧ão ocorreu em pH superior a 9, pois, do contrário, ou os dois elo mentos (Al e Fe) seriam eliminados juntos comoŕons trivalen tes solúveis (pHi muito ácido), ou os dois se precipitariam como hidróxidos (pHi neutro).

3 - Comportamento geoquímicodos elemen to 8

Os minerais residuai s primários e secundários enoon trados no material proveniente da alteração das rochas 8 ão cons tituídos principalmente de apenas três elementos: silício, alumí nio e ferro. Daí o fato de fixarmos mais nossos estudos no com 
portamento geoquímico dêsses elementos, acrescidos dos alca linos e alcalinos terrosos.

\section{a) Comportamento do silício}

Nos perfis insuficientemente drenados, a eliminação do silício não é pronunciada, poss grande partc do n.esmı, liberado dos silicatos primários da rocha, recombina-se com o alumínio, formando a caulinita, principal minexal de neoformação que se desenvolve nestas condições. Entretanto, nos perfis bem drenados a eliminação é bastante rápida e efetiva, podendo atingir valores superiores a $95 \%$, em determinados níveis de altera ção.

b) Comportamento do al umínio

Pelo estudo do comportamento do alumínio em todos os perfis analisados, ficou comprovada sua razoável estabilidade e pequena mobilidade. Seu comportamento, contudo, comofoi mostrado nos cálculos isovolumétricos, não é constante o sufi ciente para justificar os cálculos geoquímicos isoalumínio, muito usados em estudos geoquímicos de intemperismo de rochas.

Nos perfis descnvolvidos sôbre diabásios ocorre sempre uma pequena eliminação de alumínio nos estádios iniciais . em virtude do alto valor que o $\mathrm{pH}$ do meto atinge, valor êste que possibilita a permanência do ín al umínio na solução, facilitando assim sua eliminação. Já nos perfis desenvolvidos sổre granitos, tal fato não ocorre, pois o pH, menmo nos primeiros es tádios de intemperismo, não atinge valores que possibilitem a permanência do alumínio como íon solúvel. 
Nos horizontes superioreo de alteração, em partos correspondentes aos horizontes pedológicos, a eliminação do a lumínio deve ser interpretada como consequência da ação da mą téria orgânica, que provoca a instabilidade da gibbsita e promo ve sua remobilização.

\section{c) Comportamento do ferro}

O ferro possui comportamento distinto, dependendo das condições em que se verifica a evolução dos perfis.

Em condições de boa drenagem o perfil de alter ação mostra um enriquecimento em ferro na direção dos horizontes superiores, provàvelmente porque as condições de boa drena gem permitem a oxidação de ferro bivalente, liberado dos silicatos primários, para o estado oxidado $\mathrm{Fe}^{3+}$, de pequena mobilidade.

Nos perfis desenvolvidos em condições de drenagem moderada ou deficiente, a falta de ambiente oxidante permite a eliminação do ferro, como $\mathrm{Fe}^{2+}$, solúvel nas condições de $\mathrm{pH}$ reinante.

Em resumo, o comportamento do ferro dentro do per fil é controlado pelo potencial de oxi-reduçăo prevalecente. Sob condições redutoras torna-se móvel no estado ferroso, enquan to que em condições oxidantes é retido no estado f́r rico.

\section{d) Comportamento dos alcalinos e alcalinos terrosos}

O sódio e o cálcio são os que apresentam maior mobilidade, sendo eliminados quase que totalmente dos perfis de alte ração, desde o início do intemperismo. 
O potássio apresenta uma lixiviaģão mais moderada que os dois anterformente citados, em virtude de ocorrer na ro cha original, nos retículus de tectossilicatos (feldspato potássico), que apresentam grande resistência à ação do intemperismo. Além disso, pode ser adsorvido, nos retículos de minerais de neoformação, permanecendo dessa maneira, no perfil.

A eliminação do magnésio é lenta, principalmente nos estádios iniciais onde, liberado dos silicatos primários, pode entrar nos retículos de alguns minerais secundários formados nestes estádios, como roxmiculita e montmorilonita. Posterior mente, mesmo êstes minerais tornam-se instáveis, promovendo a liberação mais intensa do magnésio do perfil. 
BIBLIOGRAFIA

AGUILLERA, N.H., and JACKSON, M. L. (1953) - Iron oxide removal from soils and clays. Soll Sc. Soc. Amer. Proc. 17: pp. 359-364.

ALEXANDER, L.T., HENDRICKS, S. B., and FAUST, G. T. (1941) - Occurence of gibbsite in some soil forming matexials. Soil Sc. Soc. Amer. Proc. 6; pp.52-57.

ALIEN, V.T. (1948) - Formation of Bauxite from basaltic rocks in Oregon. Econ. Geol. 43 no 8; pp. 619-626.

ALNEIDA, F.F.N. de (1964) - Fundamentos geológicos do relę vo Paulista, in "Geologia do Estado de São Paulo". I. G. G.. Bol. no 4.1, pp. 165-253; São Paulo.

AMARAL, G., CORDANI, U.G., KAWASHITA, K., and REY NOLDS, J.F. (1965) - Potas sium-Argon dates of Basaltic rocks from Southern Brazil. Geoch. et Cosmoch. Acta vol. 30, pp. 159-189.

AMARAL, S. E. (1965) - Nova técnica de separação de minerais pesados. Bol. Soc. Bras. Geol. vol. 14, nis 1-2, pp. 83-85, São Paulo.

AUBERT, G. (1954) - La classification des sols utilisée dans les texritoires tropicaux de l'Union Française. C.R. $3 a$. Conf. Interaf. des Sols, pp. 705-708, Léopoldville.

AUBERT, G. (1961) - Influence des divers types de végétation sur les caractères et l'évolution des sols en région équatoriale et sub-équatoriale ainsi que leur bordure tropicale semi-humides. In 'Sols et végétations des regions tropicale s", Colóquio de Abidja, 1959. Pp. 4147.

BARSHAD, 1. (1948) - Vermlculite and its relation to biotite as revealed by base exchenge reactions, $X-r$ ay analyses, differential the rmal curves and water content. fim. Nilneral., vol. 33, no 11 e 12, pp. 655-678.

BATES, T.F. (1952) - Inter-rlationships of structure and genesis in the Kaolinite group. Problems of clay and laterite genesis. A.I. N. E., New York.

BJORNBERG, A.J.S. (1965) - Sedimentos pós-cretácicos do les te do Estado de São Paulo. Tese apresentada ao con cur so de Livre-Docência da Escola de Engenharia de São Carlos da U.S.P. (Inédita.)

BJORNBERG, A.J.S. C LANDIN, P.N B. (1966) - Contribuição ao estudo da Formação Rio Claro (Neocenozóico). Bol. Soc. Bras. Geol., vol. 15, no 4, pp. 43-67, São Paulo. 
BONIFAS, M. (1959) - Contribution à l'étude géochimique de l'altération latéritique. Mémoires du Service de la Carte Géologique d'Alsace et de Lorraine, no 17, 159 p., Strasbourg.

BRINDLEY, G. W. , SOUZA SAIVTOS, P. E SOUZA SANTOS, F.. L. (1963) - Nineralogical studies os Kaolinite-halloysite clays. Part I - Identification problems. Am. Mineral., vol. 48, pp، 897-910.

CAMARGo, A.P. (1760) - Bàlanço hídrico no Estado de São Pau 10. Bol. Técnico n! 116 do Instituto Agronômico do Estado de São Paulo, 20 p.. Campinas.

CAPANEMA, G.S. barão de (1866) - Decomposição dos penedos do Brasil. Lição popular proferida em 25 de junho.

32 p.. Typ. Presseverança, Rio de Saneiro.

CONIISSÃO NACIONAL DE SOLOS (1960) - Levantamento de reco nhecimento dos solos do Estado de São Paulo. Bol. Ser viço Nacional de Pesquisas Agronômicas, n? 12, 634 p, Rio de Janeiro.

COLLIER, D. (1961) - Mise au point sur les processus de l'altéra tion des granites en pays tempérés. Ann. Agron., vol. 12, no 3, pp. 273-331.

COSTA, S.V. BOTELHO DA E AZEVEDO, A. L. (1953) - Solos da Angola. Contribuição para seu estudo. Ninistério do Ultramar, Memórias, Série de Pedologia Tropical, Pấ to.

CRAIG, D.C., and LOUGHNAN, F.C. (1964) - Chemical and mineralogical transformations accompanying the weathering of basic volcanic rocks from New South Wales. Aust. J. Soil Res., 2, pp. 218-234.

DA COSTA, A.O.L. e GODOY, H. (1962) - Contribuição para o co nhecimento do clima do solo de Ribeirão Prêto. Bragan tia, vol. 21, no $40, \mathrm{pp}, 689-742$.

DELVIGNE, J. (1765) - Pédogenèse en zone tropicale. Nuémoires, O.R.S.T. O. N2.. n? 15, 177 p.

DENOLON, A. B. (1952) - Dynamique du sol. 5a. ed., Dunod, Paris, 520 p.

DOUCHAUfOUR, P. (1960) - Précis de Pédologie. Masson et Cie. Editeur 8, 1a. ed.

FERRI, N. G. (1944) - Transpiração de plantas permanentes dos cerrados. Bol. Fac. Fil. Ciên. Letras., vol, XLl, Bo tânica 4, pp. 159-294.

FETH, J.H., ROBERSON, G., and POLZER, W. (1964) - Sources of mineral constituents in water from granite rocks, Sierra Nevada, California and Nevada. U.S. Geol. 
Survey - Water Supply Paper, 1535, 1, 70 p.

CARRELS, R.M. (1960) - Mineral equilibria - at low temperature and pressure. New York, Harper and Brother, Pub., $254 \mathrm{p}$.

GIRARDI, V.A.V. e BITTENCOURT, I. (1963) - Nota sôbre a o corrência de granitos pórfiros no Muxicípio de Campi nas. Trabal ho apresentado ao XVII Congresso Brasilei ro de Geologia, Recife.

GOLDICH, S.S. (1938) - A study in rock weathering. Journ. Geology, vol. 46, pp. 17-58.

GOLDMAN, N.J. (1955) - Petrography of bauxite surrounding a core of Kaolinized nepheline syenite in Arkansas.Econ. Geol., vol. 50, ppl 586-609.

GRIM, R. E. (1953) - Clay Mineralogy。 McGxaw-Hill Book Co., Inc., $342 \mathrm{p}$.

GRUNER, J.W. (1934) - The structure of vermiculite and their collapse by dehidratation. Am. Niineral., vol. 19, n? 12, pp. 557-578.

GUERrA, A.T. (1950) - Formação, evolução e classificação dos solos. Bol. Geogr. (C.N.G.), Ano VIII, ne 88, pp. 476 481, Rio de Janeiro.

GUERRA, A.T. (1952) - Importância da alteraçäo superficial dás rochas. Bol. Geogr. (C.N.G.), Ano X, no 106, pp. 42 47. Rio de Janeiro.

GUTMANS, M. (1943) - Rochas-mater da "ter ra roxa". Bragan tia, vol. 3, n? 9, pp. 271-316, Campinas.

HARRINSON, J.B. (1933) - The katamorphism of igneous rocks under humid tropical conditions. Imp. Bur. Soil Sci. Harpenden, 79 p.

HESS, P.C. (1966) - Phase equilibria of some minerals in the $\mathrm{K}_{2} \mathrm{O}-\mathrm{Na}_{2} \mathrm{O}-\mathrm{Al}_{2} \mathrm{O}_{3}-\mathrm{SiO}_{2}-\mathrm{Hi}_{2} \mathrm{O}$ System at $25^{\circ} \mathrm{C}$ and 1 atmosphere. Amer. Journ. Sci,, vol. 264, pp. 289 309.

JACKSON, M.L., HSEUNG, Y., COREY, R. B., EVANS, E.J. , and VANDENHEUVEL, R.C. (1952) - Weathering sequence of clay-size minerals in soils and sediments. II - Chemical weathering of layer silicates. Soil Sci. Soc. Am. Proc., vol. 16, pp. 3-6.

JACKSON, M.L. (1965) - Clay transformation in soil genesis during the quaternary. Soil Sci., vol. 99, n? 1, pp.1322.

JENNY, H. (1941) - Factors of Soil formations. MacGxaw-Hill Book Co., New York-London, 270 p. 
KAPEL, I. B. e SOUZA SANTOS, P. (1963) - Análise térmica di ferencial de talcos brasileiros. Cerâmica, vol. 10, $\bar{n}$ ? 37, pp. 10-23, São Paulo.

KEELOG, C. 2. (1949) - Preliminary suggestions for the classification and nomenclature of great soil groups in tropicai and equatorial regions. Proc. Common weaith conf. Trop. Subtrop. Soil, Haxpenden, pp. 7684.

LENEUF, N. (1959) - L'altóration des granites calco-alcalins et des granodiorites en côte d'Ivoire forestière et les sols qui en sont dérivés. Thèse en Sciences. Paris $O$. R.S.T.O. Ivi., 210 p.

MARTIN, F., NiAU, F. e BJORNBERG, A.J.S. (1959) - Vale pré-glacial a nordeste de Jundiar. Bol. Soc. Bras. Geol., vol. E, ne 2, pp. 35-40.

NELFI, A.J. e BITTIENCOURT, I. (1962) - Levantamento geo lógico do Município de Campinas. Trabalho apresenta do no XVI Congresso Brasileixo de Geologia. Pôrto $\overline{A-}$ legre (no prelo).

NALIFI, A.J. e BITTENCOURT, I. (1962) - Geologia e pedolo gia da bacia glacial no Distrito de Sousas. Campinas. Bragantia, vol. $21, n$ \% 46, pp. 807-826.

MELFI, A.J, e GIRARDI, V.A.V. (1962) - Ocorrência de um sill de diabásio no arenito Botucatu, no município de Igarapava, SP. Bol. Soc. Bras. Geol., vol. 11, n! 2. pp. 55-70.

MELFI, A.J., GIRARDI, V.i.. V. e NiONIZ, A.C. (1966) - Miae ralogia dos solos da Estação Experimental "Theodure to de Camargo" em Campinas. Bragantia, vol. 25, no? 2, pp. 9-30.

MELFI, A.J. (1967) - Potassium-argon ages for core samples of basaltic rocks southern Brazil. Geoch. et Cosmoch Acta (no prelo).

MiERRIL, G. P. (1897) - A treatize on rocks, rock weathering and soils. The lviackillian, $411 \mathrm{p}$, New York.

MILLOT, G. et BONIFAS, N. (1955) - Transformations isovolumétriques dans les phénomènes de latérisation et bauxitisation. Bull. du Serv. de la Carte Géol. d'Alsace et de Lorraine, vol. 8, fasc. 1.

NLOHR, E.C. (1944) - The soils of equatorial regions with particular reference to the Vederlands East Indies. Ann. Arb. - Michigan.

MOHR, E.C. and VAN BARREN, F.A. (1954) - Tropical soils. Vitgererij van Hoeve Ed. 
MONIZ, A.C. (1964) - Estudo mineralógico de argilas do miciso alcalino de Poços de Caldas. Tese de Doutoramento (Inédito).

MORAES REGO; L. F. (1732) - Notas sôbre a geomorfologia de São Paulo e sua genesis. Inst. Astr. Geogr., 28 p.

MORAES REGO: L. F。 (i9.35) - Consideraçōes preliminares *ôbre a genesis e a distribuição dos solos do Estado de São Paulo. Geografia, Ano 1, no 1, pp. 10-51.

MUNSELL COLOR CONPANY (1954) - Munsell soil color charts. Baltimore.

PAIVA NETTO, J.E. e NASCINENTO,A.C. (1957) - Diabásios e seus produtos de decomposição. Trabalho apresen tado ao XI Congresso Brasileiro de Geologia, Salva dor (mimeografado).

PECRCT, A., GASTUCFE, N.C., DELVIGNE, J., VIELVOYE, L. et FRIPIAT, J.J. (1962) - L'altération des roches et la formation des sols au kivu. I. N.E.A.C., série scientifique $n$ ? $97,90 \mathrm{p}$, Louvain.

PEDRO, G. (1964) - Contribution à l'étude expérimentale de L'altération géochimique des roches cristallines. Thè se Fac. Sci. Inst. Nac. Rech, Agron, 344 p., Paxis.

RANZANI, G. e KINJO, T. (1765) - Considerações sôbre.o me canismo de gênese de solos provenientes de rochas pré-cambrianas: I - Anfibolito. Tese apresentada ao Il Congresso Latino Americano de Ciências do Solo. Piracicaba.

RAWITSHER, F. (1942) - Algumas noções sôbre a transpira ção e o balanço d'água de plantas brasileiras. An. Acad. Bras. Ciênc., vol. XIV, ne 1, p. 7-36.

RAWITSFER, F. (1744) - Problemas de Fitoecologia com consideraçôes especiais sçbre o Brasil Nieridional. Bol. Fac. Fil. Ciênc. Letras, vol. XLI, Botânica 4.

REICFE, P. (1750) - A survey of weathering processes and products. Publication in geology n? 3. University of New Nexico, 95 p.

SCHAUFELBERGER, P. (1951) - Clay in tropical soils. Bol. Tec. Fed. Nac. Caf. Columbia, vol, 1, ne 5, pp. $29-46$.

SCHRODER, R. (1956) - Distribuição e curso anual das precipitaçōes no Estado de São :aulo. Bragantia vol, 15, nọ 18. pp. 193-249, Campinas.

SEGALEN, P. (1957) - Etude des sols dérivés des roches volcaniques basiques ì Madagascar. Mémoires de L'Insti tut Scicntifique de Madagascar, série D, Tomo VIII, $182 \mathrm{p}$. 
SECFLEN, P. (1964) - Le fer dans les sols. Documentation Téchniques, ORSTOM, $150 \mathrm{p.}$. Pario.

SEGALEN, P. (1965) - Les produita alumineux dans les sols de la zone tropicale humide. Pedologie. Cahiers, vol. UI, fasc. 2, p. 149 .

SETZER, J. (17/6) - Contribuição paxa o estudo do clima do Es rado de São Paulo. Escolas profissionais calesianas, 23 p., São Paulo.

SETZER, J. (1960) - Identificação de sills de diabásio decompos to a. Bol. Soc. Bras. Geol., vol. 9, ni 1, pp. 63-70.

SMXXH, W. W. (1761) - Structural relationships within pseudomorphs after olivime. Nineral $\mathrm{M}_{1}$ ag. vol. 32 , pp. 82.3-824.

SCCLEDADE ERASILEIRA DE CIENCIAS DO SOLO (1756) - T2adução da carta de côres para rolos (mimeografado).

STEVENS, R. E. and CARROIN, M.K. (1948) - A Exmpla field test for distinguishing mirexals by abrasion pH. Amer. Mineral. vol. 33, pp. 31-49.

THORNTIVAXTE, C.W. (1948) - An approach toward a rational clasitication of climate. The Cieographical Review, 38. $\mathrm{pP} .55-94$.

TKORP, J. and SMITH, G.D. (1949) - Higher categories of souls classification: order, suborder and great soil group. Soil Sci., vol, 67, pp. 117-126.

UNATWD STATES DEPARTMENT OF AGRICULTURE (1738) Soils and lvien, Washington D.C., U.S. Dept. of kigrte. Xearbook, $1232 \mathrm{p}$.

UNITED STATES DEPARTMINT OF AGRICULTURE (1751) Soil Survey Nanual. Handbook no 18, Washington U.S. Dept, Agric.

WALISRR, G, F, (13417) - The decomposition of biotite in the soll. Nineral, Niag. vol. 28, no 206, pp. 693-703.

WASHBURNE, C.W. (1730) - Petroleun geology of the state of São Paulo. Com. Geogr. Geol, Bol. no 22,272 p. , Szo Paulo.

WATSON, J.P. (1965) - A soil catene on granite in southern Rho desia. Jouxn. Soll Sci. vol. 16, ne 1, pp. 238-257.

WERNICK, E. (1966) - Duartzo-pórfiros nos arredores de Serra Negxa. Trabalho apresentado ao XX Congre Bo Bragileiro de Geologia, Vitória. 